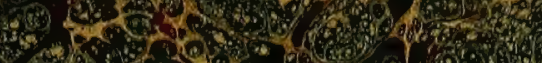

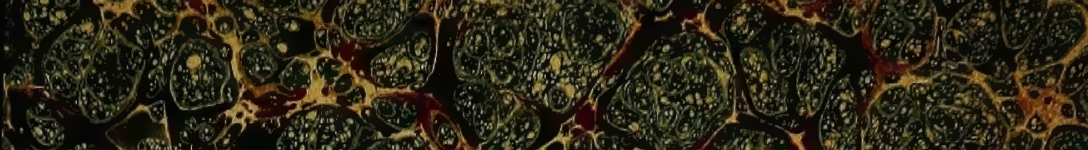

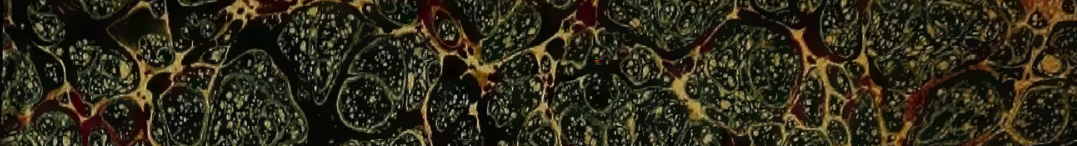

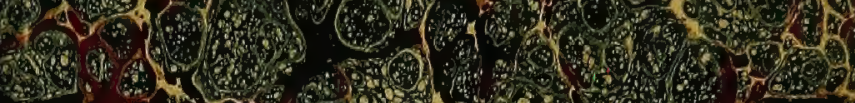

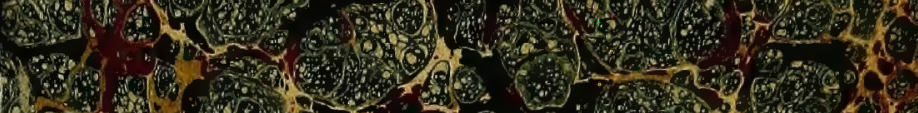

1.

8. (1)

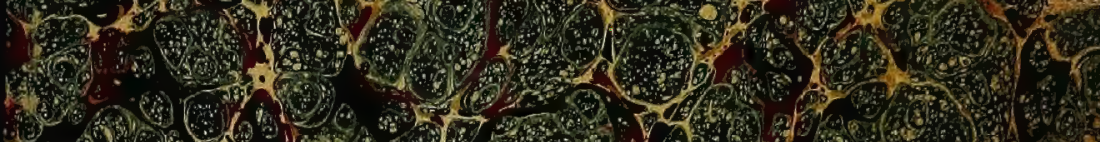

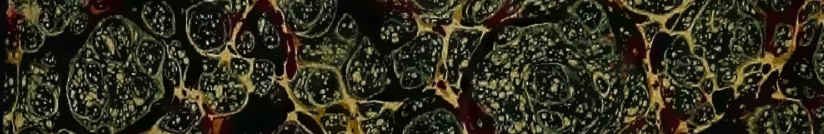

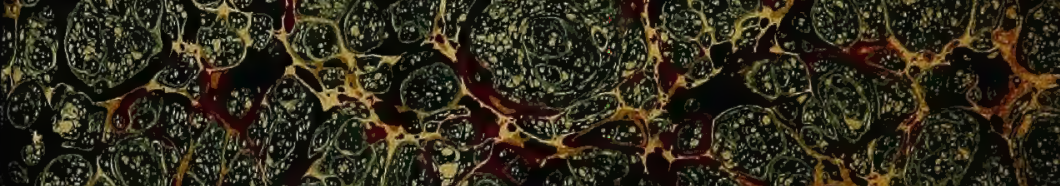

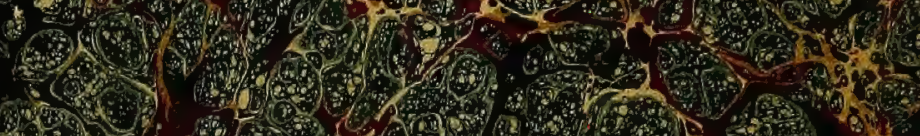
(5) 17. (3. (3)

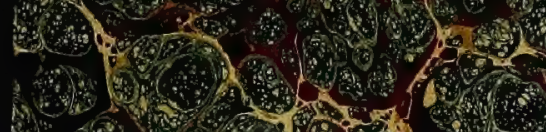

2. T. 20.9.2)

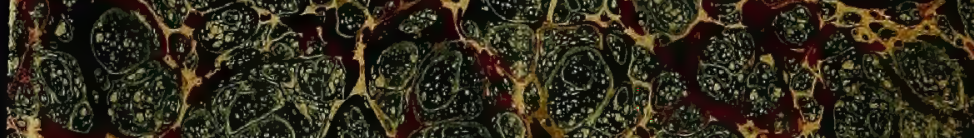

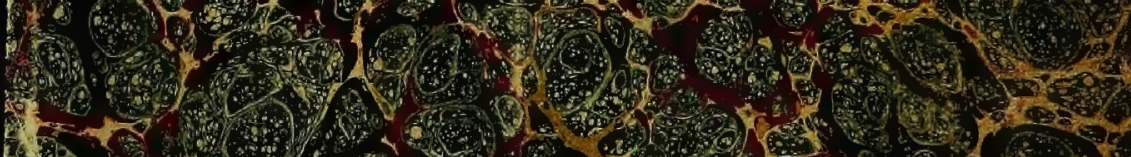
1. H.

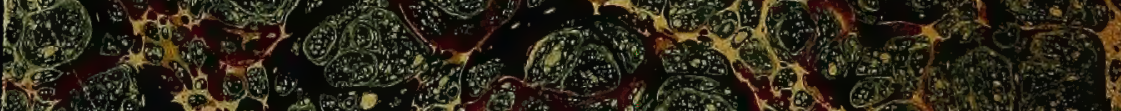
r.

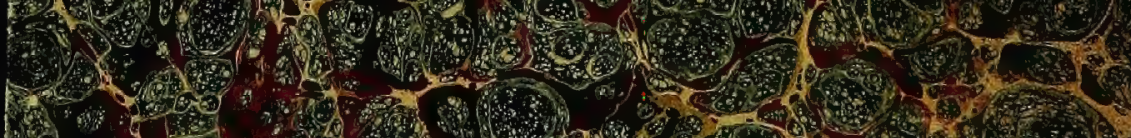

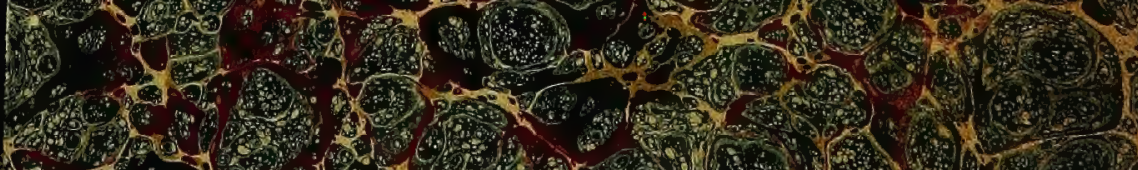

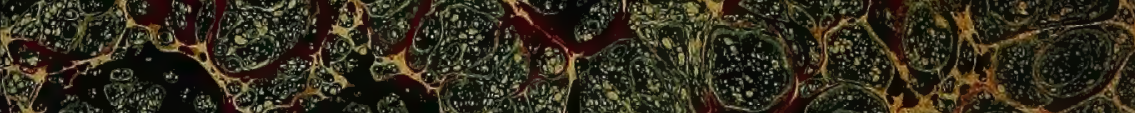
4 a 
$F$
1096
$R 96$

Conwell älunitersity

THE GIFT OF

Umversity of towa

A. 124338

$18 / 3 / 99$ 


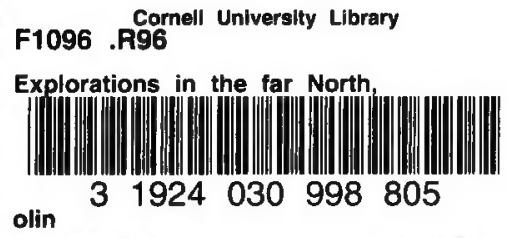




\section{Cornell University Library}

The original of this book is in the Cornell University Library.

There are no known copyright restrictions in the United States on the use of the text. 


\section{EXPLORATIONS}

THE FAR NORTH B $\mathbf{Y}$

FRANK RUSSELL

BEING THE REPORT OF AN EXPEUITION UNDER THE AUSPICES OF THE UNIVERSITY OF IOWA DURING THE YEARS 1892, '93 AND '94

PUBLISHED BY THE UNIVERSITY 1898 




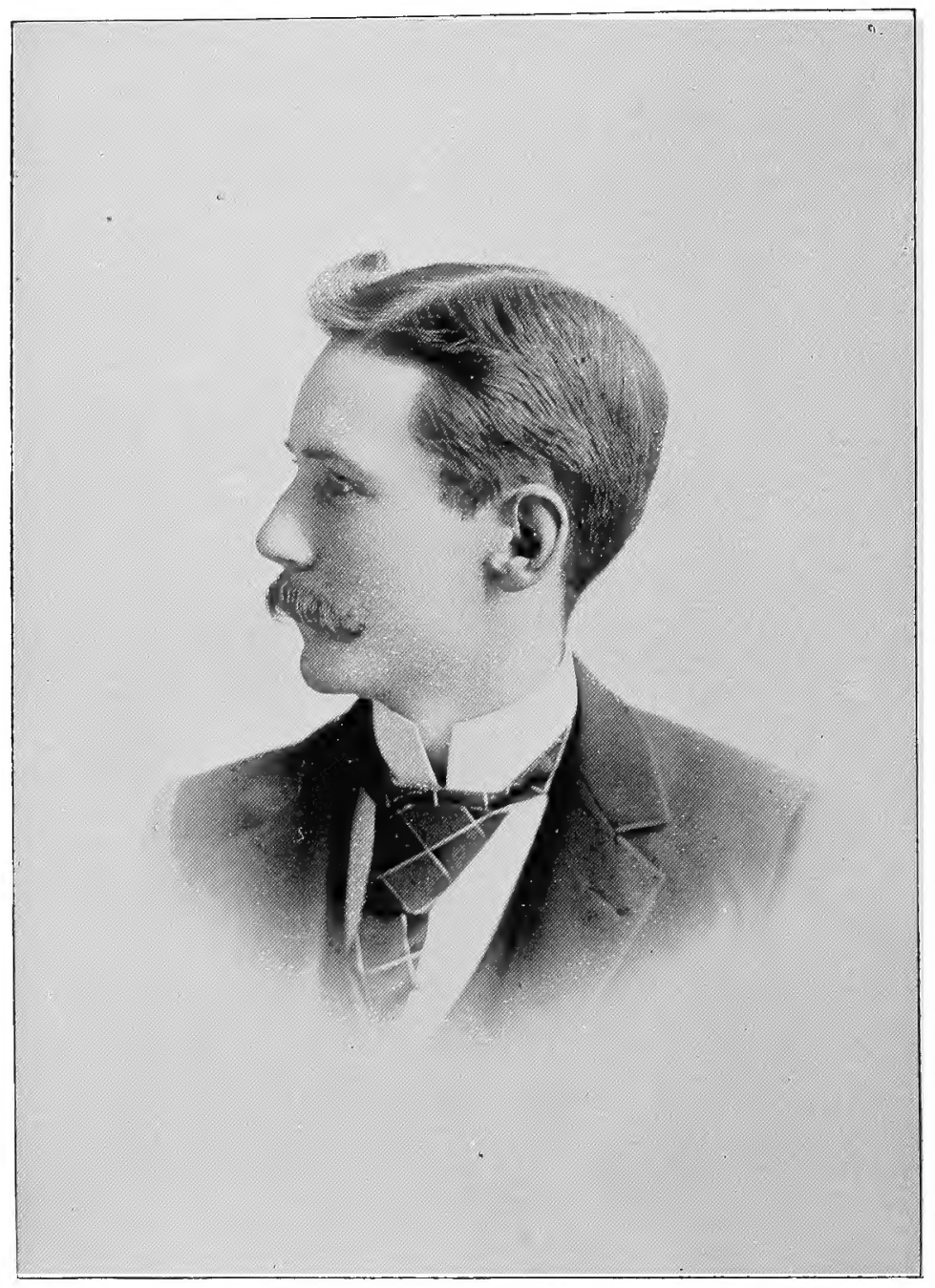




\section{EXPLORATIONS}

I $\mathbf{N}$

\section{THE FAR NORTH}

${ }^{B Y}$

FRA NK $\underset{F}{R}$ USSELL

BEING THE REPORT OF AN EXPEDITION UNDER THE AUSPICES OF THE UNIVERSITY OF IOWA DURING THE YEARS 1892, '93, AND '94

PUBLISHED BY THE UNIVERSITY

I 898 
5736034

A, 124338

COPYRIGHT, 1898 ,

BY WM. J. HADDOCK, SECRETARY OF THE BOARD OF REGENTS OF THE STATE UNIVERSITY OF IOWA, FOR THE STATE UNIVERSITY OF IOWA. 


\section{PREFACE}

EARLY in I89I, Professor Arthur G. Smith and the writer planned to undertake a journey, during the summer months, to the northern shores of Lake Winnipeg, Manitoba, for the purpose of collecting ornithological specimens. Just before our departure in June, we were joined by Professor C. C. Nutting, who, eminently fitted by his experience as a naturalist, became the leader of the expedition, which was thereafter conducted in the interests of the Museum of the State University of Iowa. During the summer two stations were occupied; the first, near Lake Winnipeg, at the Grand Rapids of the Saskatchewan River; the second, sixty miles above, where the River debouches into Cedar Lake. The results of our explorations have been embodied in a report by Professor Nutting. ${ }^{1}$

While at the mouth of the Saskatchewan I met Mr. R. MacFarlane, the ornithologist, who, during a residence in the Fur Country of nearly half a century, had made extensive and very valuable collections of natural history specimens. His enthusiastic descriptions of the field, as yet almost unexplored, roused in me a strong desire to visit the Far North. Professor Nutting, also becoming interested, after our return laid the matter before the Board of Regents of the University and eventually secured their approval of the plan to send me northward to obtain specimens of the larger arctic mammals, especially musk-ox, and, incidentally, "to pick up everything else that I could lay my hands on."

1 Natural History Bulletint, State University of lowa, Vol. II, No. 3 . 
Through some oversight no money was appropriated to carry on the work and the project must have been abandoned, had not President Chas. A. Schaeffer generously advanced the necessary amount to meet the expenses incurred during the first year.

It was my desire to go at once to the Great Slave Lake region, but it seemed best to the promoters of the enterprise that I should become accustomed to the life of the natives before going so far beyond the limits of civilization. $\mathrm{Mr}$. MacFarlane, then chief factor in charge of Cumberland District, the Hudson's Bay Company's southernmost division of the Fur Country, thought it advisable for me to spend the first winter at Grand Rapids in order to become acclimated and to become accustomed to the northern mode of winter travel, before I should attempt to enter the Barren Ground.

Grand Rapids is not a good station for a collecting naturalist. Water birds are not numerous, land birds do not differ from those more easily accessible in Manitoba. The fur-bearing mammals have been nearly exterminated. The customs and traditions of the Crees, who inhabit the country, have been so modified by contact with the whites during a period of over a hundred years, that their interest to the ethnologist has been greatly lessened. However, the work already done at that post would be enhanced in value if the collection was continued through a winter season, and it was finally fixed upon as my headquarters for the winter of $1892-3$.

As it was not desirable that I should begin collecting at Grand Rapids before autumn, at the close of the University in June, I went with Professor Smith to the Pacific Coast where we were to collect natural history specimens for our own cabinets until it was necessary for me to go to Winnipeg to secure passage on the last trip of the lake steamers.

Our first station was upon the shores of Puget Sound, near Tacoma, where we devoted most of our attention to the marine 
invertebrates. Several hundred starfishes were boiled and dried, thus preserving their form and color. The most abundant species, Asterias sp., was noticeably larger than the $A$. vulgaris of the Atlantic Coast. The sea urchin, Echinarachnius excentricus, was a common species in shore, fifteen hundred being obtained in a few minutes dredging.

A full series of the alcoholic material collected has since been presented to the University.

We were surprised to find so few water birds in that locality, the pigeon guillemot, Cepphus columba Pall., was the only species which was at all common. When we attempted to collect land birds we more fully realized the great height of the forest trees, in whose towering tops they flitted safely about, quite beyond the reach of small shot.

We left Washington, late in July, for the second station, which we were to occupy in the mountains of Central British Columbia. When we crossed the international boundary at Huntington, the person acting as collector of customs for the Dominion insisted on the payment of duty on our effects with the assurance that it would be refunded when we recrossed the line. Let me here extend a warning to any too-confiding naturalist who may meet that over-zealous functionary-if you wait until you reach the boundary again you will never recover your money. Some premonition of this fact induced Professor Smith to request in person at the Winnipeg office that the money be refunded, and even then the money was only returned after months of persistent correspondence.

We take pleasure in acknowledging our obligation to $\mathrm{Mr}$. A. Campbell Reddie, Deputy Provincial Secretary of British Columbia, for the license granted us to hunt animals protected by the provincial game laws.

We had intended to descend the Big Bend of the Columbia, but this plan was abandoned when we found that there was no suitable boat at Donald. We then engaged an old hunter and 
prospector as guide at "gold prices" and set off on foot to ascend a spur of the Rocky Mountains, seven miles from the village, where mountain goats were said to be found. There was no trail for pack horses, so we packed our outfit on our backs. After two days of hard climbing, a part of the way through an almost impenetrable jungle, we reached the timber line and encamped on the sharp crest of a long ridge which was covered in places with banks of perpetual snow. From our camp seven glaciers were visible on neighboring peaks. The mountains bounded the horizon on every side. The broad valley of the Columbia between us and the Selkirks was sometimes obscured by clouds that frequently rose and enveloped us in mist, rain, or snow. The grandeur and magnificence of the situation hardly compensated for the discomforts of a shelterless camp.

We remained there until our provision was exhausted. We secured, during that fortnight, specimens of the mountain goat, Haploceros montanus, woodchuck, porcupine, Erethizon dorsatus, etc. Woodchucks were very abundant above the timber line. On one occasion I saw fifteen in a single group. The timid squeak of the little chief hare was often heard, but, owing to its wariness only one specimen was obtained.

We reached Winnipeg August I 5 th, whence Professor Smith returned to Iowa, and where I spent several days awaiting the arrival of my collecting outfit from Iowa City.

I am indebted to many friends for assistance. I wish especially to render grateful acknowledgment of the kindness. shown me by President Chas. A. Schaeffer, and Professor C. C. Nutting, without whose substantial aid and encouraging letters the expedition must have been a failure. I must thank the many students and members of the faculty who contributed toward the fund which was so greatly needed for the purchase of additional supplies for the second year; and the citizens of Iowa City and members of the University for the warm recep- 
tion tendered me on my return. For kindly assistance in the field I am indebted to Mr. R. MacFarlane, Mr. Joseph Hodgson, Mr. William Mackinlay, of Resolution, Captain J. W. Mills, of the Steamer "Wrigley," and many other officers of the Hudson's Bay Company; to the officers of the Herschel Island whaling fleet: Captains H. H. Norwood, E. C. Murray, and E. W. Newth, all of whom either gave specimens to our museum or assisted in their transportation.

Frank Russell.

Cambridge, Mass., December, 1896. 



\section{TABLE OF CONTENTS}

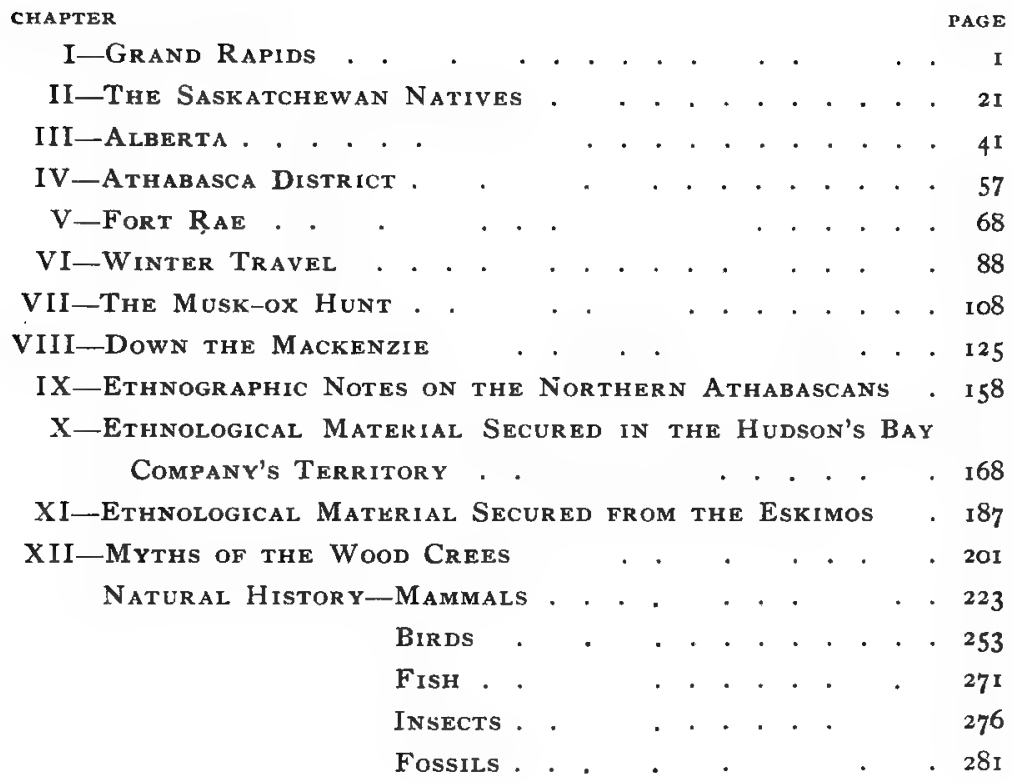





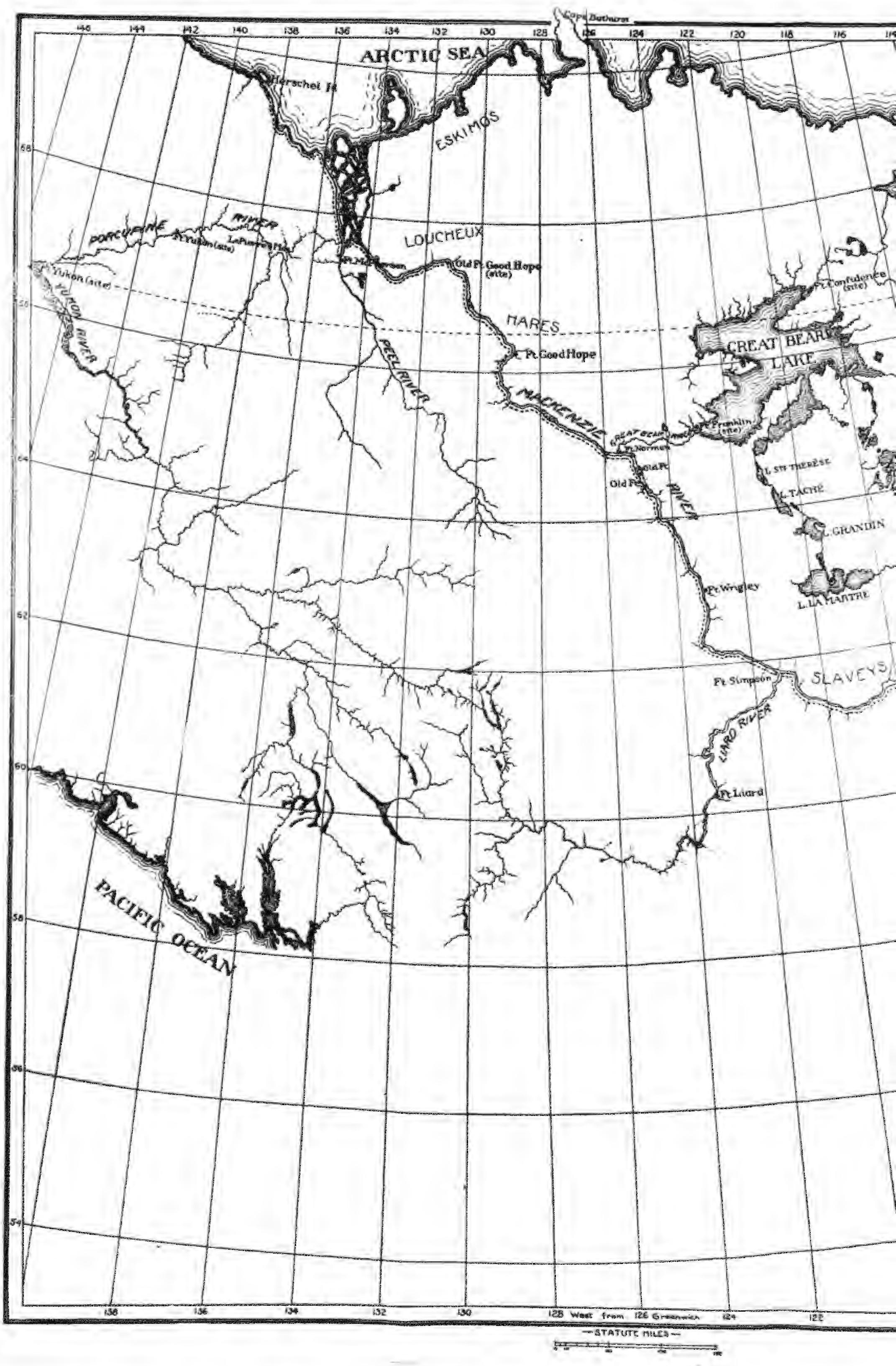




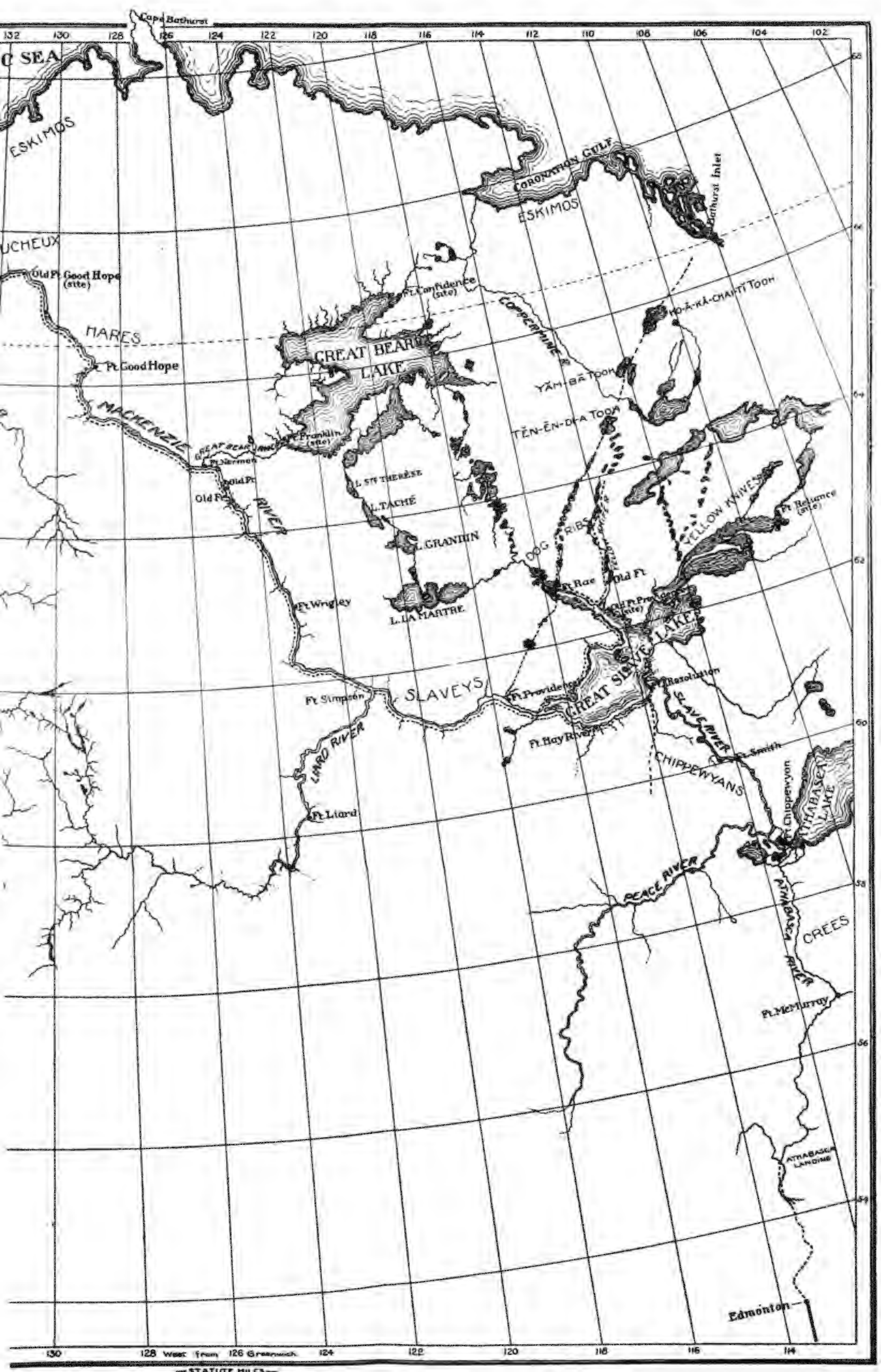




\section{EXPLORATIONS IN THE FAR NORTH}

\section{CHAPTER I \\ GRAND RAPIDS}

$\mathrm{O}^{\mathrm{N}}$ $\mathrm{N}$ the 24th of August, I 892, I left Selkirk, Manitoba, bound for Grand Rapids, on the "Colville." The "Colville" had been engaged for many years in carrying freight to the Saskatchewan River, and, of late, has brought frozen white-fish from the stations along the northwestern shore of Lake Winnipeg to Selkirk, the present southern limit of navigation on the Red River of the North.

On the following day, we ran into the harbor at Swampy Island to escape a northeast gale which delayed us for twentyfour hours. A packing company has erected buildings on this island and an extensive fishery is carried on early in the season. In August the station is abandoned and the nets are set farther north, off the mouth of the Saskatchewan. As we landed, we were met by a number of Indian dogs which had been left there to shift for themselves during the summer. Gaunt and hollow-eyed, they patrolled the beach in search of the chance fish which might have been cast up by the waves. Pelican Island, a noted breeding place of the white pelican, lies just north of "Swampy" harbor.

The passage across the broad upper lake was a stormy one. The "Colville" fully sustained her reputation of "the worst roller on the lake." The narrow hull and flat bottom required to pass the bar at the mouth of the Red River, made the boat very uncomfortable and even unsafe in heavy seas.

We reached the fishing station at Grand Rapids on the 29 th of August. The buildings stand at the narrow mouth of the Saskatchewan and are used for a few weeks only each year. 
The Hudson's Bay Company's establishment is situated a mile and a half above the "Fishery." It consists of two empty warehouses at the steamboat landing, unused since the Canadian Pacific Railway diverted the stream of traffic from the Saskatchewan, and three log cabins, one of which is known as the "store," another as the "big house," or clerk's residence, and the third is too old and dilapidated for winter occupancy, but I was compelled to lodge there as the big house was very small. My cabin was built of hewed logs, chinked with moss and daubed with clay. The autumnal "mudding" was poorly done, and the second wash with muddy water, which is usually applied after the frosts have come, failed to fill the cracks. The floor was loose and allowed currents of cold air to rise continually, which the big box stove, though heated to a cherry red could not overcome. The earth-floored Indian huts were much warmer, though heated only by narrow fireplaces.

Before leaving Winnipeg I had obtained a letter of credit from the Hudson's Bay Company, or the "Company," as it is known in the north, which enabled me to obtain supplies from any post in Cumberland District,- - embracing the Lower Saskatchewan and the country northward to Reindeer Lake. Trade with the natives is carried on by barter. There is no "sooneyow" (money) in circulation, though values are reckoned in dollars and cents.

I began collecting the day after my arrival, with the intention of making as complete a list as possible of the birds of that locality. I usually spent the forenoon in the bush and the afternoon in making up the ten or twelve "skins." "Old' Joe Atkinson, an English métis from Hudson's Bay, would watch me by the hour, te-heeing with delight as each specimen was prepared and placed in its fluffy, cotton shroud on the drying shelves. But the natives never quite understood why I wished to collect the "pe-yas-is-ak"-little birds.

The time was not all occupied, however, in collecting birds. Though I was well acquainted with the topography of the surrounding country, owing to my residence there during the summer of ' $9 I$, I had not yet found any human remains that could be identified with certainty as belonging to Crees of unmixed blood. Early in September, I was so fortunate as to discover several burial places. 
The post is situated a mile below the Grand Rapids, which are three and a half miles in length. A trail had been made along each bank of the river by the Indian fishermen who resort to the rapids to "scoop" white-fish. Beside this path, at the foot of the rapids, lay a heap of brush, which, I was told, marked the resting place of an old chief who, when dying, had directed that his people should lay him to rest beside the singing waters, and that everyone in passing should break a twig and throw it upon his grave. So faithfully had his wish been complied with that a heap of brush three feet in height had been accumulated. The tradition added to the probability that the grave contained the remains of a Cree of pure blood. Any investigation on my part, had it become known, would have made further residence at Grand Rapids very unpleasant. I proceeded, therefore, to examine the place alone. Clearing away the rubbish and a poplar tree, six inches in diameter, which grew directly over the grave, a number of flat stones were exposed. After digging through three feet of sandy loam, a mass of decayed birch-bark was disclosed, under which lay the skeleton, reclining upon the left side with the legs drawn up. The head was towards the east. A small neatly carved pipe of dark fine-grained schist lay beside the skull. A few flakes of rust - all that remained of a knife - and a couple of ounces of shot, indicated that his death had occurred since the advent of the whites.

A few days later another grave was discovered a half mile farther up the river. A French métis had broken through the turf, disclosing the skull, at sight of which he had fled in superstitious terror. After some searching I found the grave in a little opening among the pines, unmarked, and at some distance from the bank of the stream. The skeleton was drawn up in nearly a sitting position, with the head towards the southeast. Beside it were found the crumbling remains of a loon's skull and a rude stone pipe-bowl. Mr. Otis J. Klotz mentions ${ }^{1}$ the occurrence at Grand Rapids, of a "few pieces of broken pottery which were found, together with some skeletons and deer horn implements, by the Indians, while digging a hole for storing next season's potatoes. Their date must be pretty old, for the present generation of Indians here knows nothing, not

IAnn. Rpt. Dep. Int., 1891. Pt. II, p. I9. 
even by tradition, of the art of pottery." These remains were found on the right bank of the river directly opposite the chief's grave mentioned above. They were buried in dry white sand, in which, after further search, I found a number of human bones, which, with those found and reinterred by the Indians, comprised one skeleton of an adult, one disarticulated skull, and the skull of a child about five years of age. The crania are distinctly unlike those of the Crees, as the measurements elsewhere given show. It seems probable that these remains are of the people that occupied the country before the Cree invasion, and whose skeletons and pottery are found in the Manitoba mounds. ${ }^{1}$

First Moose Hunt. During the month of September, Napasis ("Boy"), the best hunter on the reserve, killed several moose in the muskeg, ${ }^{2}$ south of the post. Through the efforts of Professor Nutting, during the preceding year, we had secured two mountable moose-skins, but more were needed to complete a series, so I proposed to Napasis that he should "show me how to kill moose." I knew from the experience of the others that he would be quite willing to lead me through the swamps as long as his pay was continued, and that if he found moose he would probably guide me away from them. Why should he give me a moose that he could come next day and kill for himself? I therefore agreed to pay him a dollar and a half a day, to buy the moose that he should kill, and to give him a "present," which, as it seems to be something for nothing, is usually more talked about when making the contract, and more highly valued than the wages paid.

${ }^{1 D r}$. Bryce considers this earlier race to have been probably "Toltecan," and gives the northern limit of the country occupied by them at $52^{\circ}$; this should perhaps be extended to $54^{\circ}$. "The Winnipeg Mound Region," Report A. A. A. Sc. $1889, p$. 344 .

2 The muskeg is a characteristic feature of northern topography. From the International Boundary to the Arctic Sea the term is applied to alluvial areas with insufficient drainage over which moss has accumulated to a considerable depth. These swamps are usually covered with tamarack and fir trees. The typical muskeg is traversed by meandering streams having deep channels but a scarcely perceptible current. Stagnant pools become coated over with moss of sufficient strength to temporarily sustain the weight of a man. In places the surface is broken by tall hummocks, the têtes des-temmes of the voyageur, which turn under the foot, and sooner or later precipitate the passing pedestrian into the mud or water below. 
We set off in an old leaky birch canoe, on the $25^{\text {th }}$ of September. We were to follow the lake shore to the base of Long Point, twenty-five miles southeast of the post. This narrow peninsula was appropriately named by Mackenzie, who, in I80I, passed around the head of it, which projects twenty-five miles from the main line of the coast. It is only five miles wide and its central ridge of limestone is flanked on the north by a muskeg which gradually descends to the swampy little bays which are enclosed by a barrier beach of sand.

The Indians were establishing their camps along the shore of the lake for the fall fishing, as we passed. The north wind blew raw and chill; the mosquitoes had given place to sandflies; the smoky haze, the whistling wings of the migratory water fowl, all betokened the approach of winter.

After our "metsook" of bacon, bread and tea, Napasis spent the evening in making "cakes." He used two canoe paddles for a kneading board and a frying pan for an oven.

We ate our metsook at sunrise the next morning and started across the muskeg. We found abundant signs of the presence of moose as we climbed over fallen trees and plodded through swamps, sinking deep in the moss at every step. After five hours of steady tramping we returned empty-handed for our midday meal. This was soon dispatched and we were ready for the trail again. Napasis led at a rapid pace, while I followed in his footsteps to avoid breaking twigs, the sound of which would have frightened the moose.

Early in the afternoon Napasis discovered a fresh track. which he followed until he became satisfied from examining the bushes upon which the animals had browsed, that they were near at hand; he then left the trail and pursued a course parallel to it according to the Indian custom. We kept on for an hour when, as we were traversing a level stretch of burned timber, we caught sight of two moose, seventy-five yards distant. Napasis fired at the exposed flank of one and broke a leg. The other made off, and I supposed that it would soon distance us and began to empty my Winchester towards the fleeing animal. "Nomuch" shouted Napasis, adding several emphatic phrases which he translated by a beckoning sweep of his arm as he began to run. Hatless and breathless we fairly flew over brush heaps and bogs. After a run of half a mile we were 
again within range; I fired, and the bullet pierced both the right fore $\operatorname{limb}$ and the heart of the moose. This was my first moose, and I had secured two excellent specimens, and felt justified in giving vent to my feelings in a shout of triumph. Napasis, too, was greatly pleased, and talked excitedly in unintelligible Cree.

The next morning a strong breeze prevented our returning to the post. I tried to induce Napasis to continue the hunt, but he only said "aha"-yes-and stupidly grinned at the proposition. It was against all precedent for a man to tramp around another day after meat when he had a week's supply on hand, so he spent the day lying on his back singing or gorging himself with moose meat and cogos (bacon). The next morning we worked along shore half way to the post, but could go no further against the strong wind. I did not like the idea of spending the night where we were, and set off towards the post afoot, intending to swim the entrances of two deep bays that intervened. On reaching the first of these, I found a canoe lying upon the beach, and pushing back through the fringe of willows, came upon an Indian, Peter Turner, seated with his wife before the fire, surrounded by five half-naked children. They had no shelter of any kind to protect them from the chilling wind. A pair of wet and very ragged moccasins lying before the fire told that the man had been hunting through the muskeg, and the absence of the simmering kettle showed that he had been unsuccessful. Peter was much amused at my predicament but informed me in very bad English that he would set me across the bay with his canoe and that I could go around the next one. Fearing that I would lose my way, he accompanied me to the post. He moved at a dog trot, which I, wearing a pair of heavy boots, found it hard to maintain. We passed several quaking bogs which had to be taken at a run or we should have broken through the crust of roots and moss and quickly sunk into oblivion. We passed through an open meadow where a winding ribbon of open water indicated the presence of a deep and sluggish stream. This we crossed upon a foot-log, the ends of which were afloat in two feet of water with nothing to prevent its rolling. The channel was fully ten feet deep, but with a pole in each hand and rifles slung on our backs, we succeeded in getting across. Within half a mile we 
encountered another stream called "Crow duck" (Cormorant) River, which we crossed in a similar manner. I had been travelling since day-break and my water-logged boots were becoming a heavy, chafing burden by the time we reached the Saskatchewan. The river with its mile-breadth of water, rippling and dancing in the starlight, yet hurrying swiftly on, was the last barrier between us and the post. This my self-appointed guide ferried me safely over. As he pushed out again the words reached me in the darkness, "I go back to-night" accompanied by a laugh, as if that ten mile tramp through dangerous swamps was a huge joke. I was soon enjoying liberal doses of the never failing remedy of the North for cold and dampness-hot tea, and attacking my belated supper with a sportsman's appetite-a possession not to be despised in such a country.

Second Moose Hunt. On the third of October, I again visited Long Point acccompanied by a French métis, who, like myself, wished to see if he could kill a moose without the aid of an Indian hunter. We reached the muskeg where we were to camp, early in the morning. As we paddled our canoe up a small, winding stream we saw many moose tracks and at last decided to pitch our camp beside the creek and continue on foot. We found a few minutes later that in unloading the canoe we had alarmed a moose which had been lying at the water's edge just around the next bend, where we should have come upon him had we continued a few yards further, but he was out of range when discovered, and it would have been useless to attempt pursuit. The stream flowed through a large brûlé in which were occasional openings and clumps of green timber. As we were working our way slowly through the maze of fallen trees, one on each side of the stream, I heard the report of Louis' rifle. I hastened towards him, and very carelessly ran into a little open meadow when I ought to have kept myself concealed in the forest; as I entered it a frightened moose, carrying a fine pair of antlers (not the largest ones that I ever saw), appeared upon the farther side. He stopped and looked about for a moment, then with one plunge disappeared in the thicket, quite unharmed by the too-hastily-aimed bullet sent after him. Louis had fired at a cow at long range "just to see 'er jump." 
As I was nearing camp alone after a hard day's tramp over the yielding moss, I saw a large moose in an opening about five hundred yards away. He was walking slowly, feeding as he went. At that distance he was not easily distinguishable from the black masses of earth and moss, which clung to the upturned roots of the fallen trees. The animal was crossing a level swamp, an almost impenetrable brûlé in which charred tamarack poles prevented a rapid and silent approach. The sun was just dipping below the horizon as I waded across the creek, waist-deep and icy-cold-and began the stalk. There was scarcely a breath of wind to prevent the moose from hearing the least sound, so that I expected to see the big-eared brute make off at any moment, yet I succeeded in approaching within a hundred yards without alarming him. The sand-flies embraced the opportunity to swarm over my face and hands, where, in the excitement of the moment, their stings were unnoticed; later when their presence was recalled by the smarting pain, I realized that my face was streaming with blood as a result of their attacks. ${ }^{1}$

Vexed at the previous failures of the day, I was determined to do careful shooting. The moose started at my first shot; then stood swinging his head while I ran twenty yards towards him. Taking deliberate aim I fired again, breaking a fore leg. I then advanced to within thirty yards of the moose and fired four times at his partially exposed side. But I had too great confidence in the killing power of the heavy rifle and, though I took time to aim as carefully as possible, did not take pains to work around opposite his side that I might strike a vital spot. A moment before I fired the last time I would not have taken a hundred dollars for my chance of getting that pair of antlers, which were the largest I ever saw; a moment later I would have given as much for another cartridge. The moose stood in his tracks for five minutes, and, beginning to

1 "How can I possibly give an idea of the torment we endured from the sand-flies? As we dived into the confined and suffocating chasms or waded through the close swamps, they rose in clouds actually darkening the air; to see or to speak was equally difficult, for they rushed at every undefended part, and fixed their poisoned fangs in an instant. Our faces streamed with blood as if leeches had been applied; and there was a burning and irritating pain, followed by immediate inflammation, and producing giddiness, which almost drove us mad."-Back, Narratize, p. I79. 
hope that he was too seriously wounded to escape, I started after ammunition which, of course, I should have had with me. At last he slowly started, hobbling painfully upon three legs. I followed him for two miles and succeeded in turning him twice, but never near the camp; at last he entered an abominable jungle of fallen trees, where I had to abandon pursuit in the growing darkness as he was every moment increasing his pace. We were unable next day, in such a maze of tracks, to follow his trail, and a fine specimen was thus lost to science through my poor shooting. I was somewhat chagrined, as I had rather prided myself on my success of the preceding week. The peculiar behavior of the animal seemed to me to be worthy of record. Though I lost the moose the experience has been of value. ${ }^{1}$

Louis came in later and reported having seen four red deer during the afternoon. We had stumbled upon our game without the aid of Indian hunters, there was some comfort in that, but to let it escape so easily marked us as "nesoo mo-ni-as-uk" -two greenhorns-of the most verdant type.

We remained a few days longer in camp, unable to continue the hunt owing to the calm weather. His scent is so keen, that it is practically impossible to approach a moose in the muskeg unless there is a wind blowing. During the nights (clear and frosty) the moose sometimes came within a hundred yards of our tent, where we could hear them tramping about. I suggested fire-hunting to my companions, who declared that they would immediately leave the neighborhood, if we attempted it, and that the Indians never resorted to this method of hunting. I very much regret that we did not try it as the day fixed for our return arrived before the weather permitted us to reënter the muskeg. On the IIth of October we were favored with a southeast wind which, however, came too late to be of further service than to drive our canoe under blanket sail toward the post. The fresh breeze raised a sea, over which our little birch canoe rode lightly and safely, though we had to turn it to meet the curling crests of the largest waves. Twelve miles

${ }^{1}$ Upon my return to the post I learned that moose-skins with a dozen bullet holes in them were sometimes traded at the store. I heard of natives who after firing ten or twelve shots at a moose without effect had then thrown down their guns and climbed a tree, fully convinced that they had been shooting at the devil! 
from our destination, a projecting point, terminated by a line of shoals, necessitated a portage of a few yards. We were compelled to land in the surf of the exposed beach. Leaping into the water at a favorable moment we flung a few heavy articles ashore, then carried up the canoe before another wave could take us off our feet or break the canoe upon the rocks.

Two Cree families were living near by in lodges of birch-bark and rushes. These miserable shelters seemed very comfortable to us as we dried our garments before the cheerful fire. The Indians had watched our landing and shook their heads as we spoke of continuing the journey. In rounding the next point we heartily wished that we had heeded their advice, as the rough seas nearly swamped us in the evening darkness.

The Boat Trip to Cedar Lake. For a few days after returning from Long Point I spent the time in collecting land-birds. The water-birds were passing southward in considerable numbers, but there were no feeding grounds nearer than the delta of the Saskatchewan, on the northwestern shore of Cedar Lake. I had visited that locality during the summer of I89I, and knew that it was an excellent station for either collector or sportsman.

The Company's establishment, known as "Cedar Lake," and the Indian reserve of Chemawawin ("a seining place"), are surrounded by extensive silted flats which are covered with a luxuriant growth of rushes and grasses, and contain many small lakes, about which the cry of the waterfowl may be heard from April to November. Chief trader King, then in charge of Cedar Lake House, sent me a cordial invitation to visit his post, sixty miles distant. In the hope of securing both specimens and a store of game for the winter, I accepted the invitation. A boat, loaded with freight, was to be sent up from Grand Rapids, thus affording me the necessary assistants and means of transportation.

On the I5th of October we were visited by one of the worst storms ever known in that region; a terrific gale from the northeast destroyed docks and carried away boats. The low grounds, where the natives were encamped, engaged in the "fall fishery," were flooded, and many nets were lost. This gale swept away the ducks and geese from Cedar Lake, but we, in blissful ignorance of the fact, started up the rapids on the I 9 th. 
The crew consisted of three métis and the Cree hunter, Aleck Easter, who did not understand a word of English. Our craft was a metal yawl which had formerly been carried by one of the river steamboats. It was loaded with a few pieces $^{1}$ for the river posts.

We left the post late in the day, according to the custom of northern voyageurs. This is an excellent plan, for no amount of forethought on your part will insure sufficient preparation on the part of the men to enable you to get away early in the morning. One is sure to sleep badly the first night, and if he has been traveling all day he will find the hardship less endurable than if he had only attempted to get clear of the post before pitching camp.

Our boat was poled through five miles of rapids before we halted for the night. The snow was two inches deep, the men were tired, hungry, and wet from wading. A roaring fire soon dispelled the darkness, and a few minutes' work provided spruce boughs upon which to spread our blankets. The next morning, after "drinking tea," as breakfast or any other meal is designated, we crossed in the midst of the rapids and continued by means of the tracking-line. The men on the line at times waded waist deep in the stream; again, they crept along the face of the limestone escarpments, at the base of which the cur: rent ran deep and swift.

We used the oars on Cross Lake, which is about seven miles in width, its northern shore not visible from the traverse. The river enters the lake by a descent of about five feet, which forms the rapids known as the Demi-charge. Our crew was small, and not even a "half-load" could be tracked up the rapids. After carrying the freight across the portage of two hundred yards, the attempt was made to drag the boat through with three men on the line. The banks were obstructed by fallen trees, over which the tracking-lines of the traders have been passed for over a century without anyone ever taking the trouble to clear away a single branch. The men tugged at the line until they were stretched nearly flat on the rocks, to which they clung with hands and moccasined feet. Just as the boat was on the last ledge, and the hitherto derisive shout of the

'The bundles or boxes, averaging ninety pounds each in weight, in which the Company's goods are packed, are known as "pieces." 
steersman of "haul! haul! haul!" changed to an appeal, the line broke and the boat was swept back and an ugly hole broken in the side by the rocks - the work of an hour was undone in a few seconds. The boat was repaired with tar and cloth, and a second attempt was made. The whirling waters caught the heavy sweep, which swung around so quickly that the steersman was hurled into the midst of the rapids. Fortunately he was not injured and regained the boat as it dropped down stream. The third attempt was successful.

The following day we reached Cedar Lake. ${ }^{1}$ We were awakened at $4 \mathrm{~A}$. M. on the morning of the third day by the steersman who insisted that we push on with the oars or we should be "frozen in" before we reached our destination Shortly after daybreak we were again wind-bound, and the day was spent in camp at Rabbit Point.

The days were now invariably cloudy, but the wind died away in the evening and the sky cleared so that we could see to travel. We set out again at five o'clock pushing on through the long twilight while the swell still rocked our little craft, into the calm of the winter night.

The aurora appeared early in the evening, at first with a broad yellowish band along the northern horizon; this crept upward, folding and unfolding like some uncanny living thing, then tongues and sheets of flame went flashing to the zenith, changing rapidly while the band at their base continued its shifting. The frost occupied itself with exposed parts for awhile, then pierced through every wrap, and it not only looked but felt like a sub-arctic scene. Every half hour the men took their "spell," resting long enough to cut up and smoke a pipeful of tobacco or kinnikinic.

We reached Chemawawin on the morning of the fifth day. We learned that only a few ducks had been seen since the gale,

I "Cedar Lake (so called from the occasional groves of cedar-a tree rarely seen in Rupert's Land-growing on its shores, particularly at its western extremity), is an expanse of water of considerable extent in which the turbid waters of the Saskatchewan are allowed to disseminate and settle before uniting into one great river and rushing down the Grand Rapids into Lake Winnipeg."--Hind, Rpt. on the N.W. Ter., p. 76. It was called Lac Bourbon by the early Canadians. "C'est en I728 que M. de Reverendie decouvrit ce lac et lui donna le nom lac Bourbon, (en anglais Cedar Lake)."-Faraud, Henry, "Dix-huit ans chez les Sauvages," p. 7o. 
and that these had been hunted by the natives until they had become very wary. With Donald and Aleck I set off in a birch canoe to try and bag a few of them. On our way the "boys" amused themselves by firing at the muskrats, which were more abundant than the ducks. More than one rat was blown to pieces and the pelt ruined, of course. This seemed to afford the keenest delight to my crew. We were to take our stand on an island to reach which we must cross a half-mile of shallow water, now covered with thin ice. Donald soon wore out a paddle in breaking through it. Half way to the island we began to drag on the muddy bottom; the men sprang out and dragged the canoe forward, breaking the ice with their bare feet. I had not yet become accustomed to wading in ice water, and when the canoe stuck hard and fast several hundred yards from shore, I hesitated about getting into the water. Donald was quite willing to carry me, but he sank so deeply in the mud that I was at last compelled to wade. Two years later I would have taken it as an every day matter, but at the time I considered it a hardship. I gave the boys a supply of ammunition with which to hunt on their own account. The métis, Louis, also made a "stand" near us. If the game secured had been in proportion to the powder burned by the four guns that day, I would have recorded here the result of our efforts, - anyone wishing further information concerning the avifauna of Chemawawin, on the $25^{\text {th }}$ of October, 1892, is respectfully referred to my private journal!

The next morning a fair wind enabled us to set sail for home. At eleven o'clock on the second day we were in sight of the tramway above the Grand Rapids, when Aleck, ever on the lookout for game, pointed to a moving object at the water's edge a mile below, and said "mooswa." It was a young moose of the season, a specimen which I was particularly desirous of obtaining to complete our series. Aleck had left his gun at his camp up the river, but as he had killed sixty-nine more moose in the last six months than I had, I thought it surer to send him after the game with my Winchester than to go myself. Aleck seemed greatly excited, not nervously so, but with the eagerness of the well-trained hunter. The moose entered the woods with the boy in close pursuit; soon after we heard a shot and saw the wounded animal dash into the river. 
We sprang to the oars and hastened towards it, soon finding, however, that it was floating, lifeless, its skull shattered by the heavy ball. All hands laying hold, we dragged it into the boat, and a few minutes later were at the end of the tramway across the portage, where we loaded it on a car and carried it to my very door.

In November I continued the daily field work, collecting birds and small mammals. The chickaree, or red squirrel, the anikwichas of the Crees, was quite abundant; its defiant chatter might be heard on any fair day throughout the winter. I also snared a number of northern hares. These animals are seemingly very fond of twine. During the first night they were set, fifteen of the nineteen snares were cut and chewed by the animals which they were intended to capture. The Indians sometimes rub ermine's liver on the snares to prevent their being eaten, but usually a large number are set, and patiently renewed if destroyed. At least half the hares are caught by the hind legs in passing through the snare; as a result their flesh has an indescribably disagreeable flavor which is not found in those caught by the neck.

During my morning hunts I frequently walked fifteen or twenty miles, and found more and more difficulty in securing specimens enough to occupy my attention during the rest of the day.

During the morning hunt of November 2Ist, my face was frost-bitten for the first time. Snow fell nearly every day and accumulated to such a depth that travel through the bush became very fatiguing. My journal contains the following entry for December 6th: "Spent the afternoon in the field, secured one red-poll! I left the portage trail to hunt in the bush, found it almost impossible to manage my small snow-shoes in the soft snow and took them off only to find myself sinking waist deep in the snow! Alphonse Propontier remarked this morning that during a residence here of twenty-three years he had never before seen the snow so deep at this season." Under such circumstances the collection of birds became unprofitable as the number of species was reduced to the few winter residents.

Dog Driving. On the I 6 th of November, I took my first lesson in dog driving. Even then I felt an anticipatory chill at the thought of the hundreds of miles of that kind of travel- 



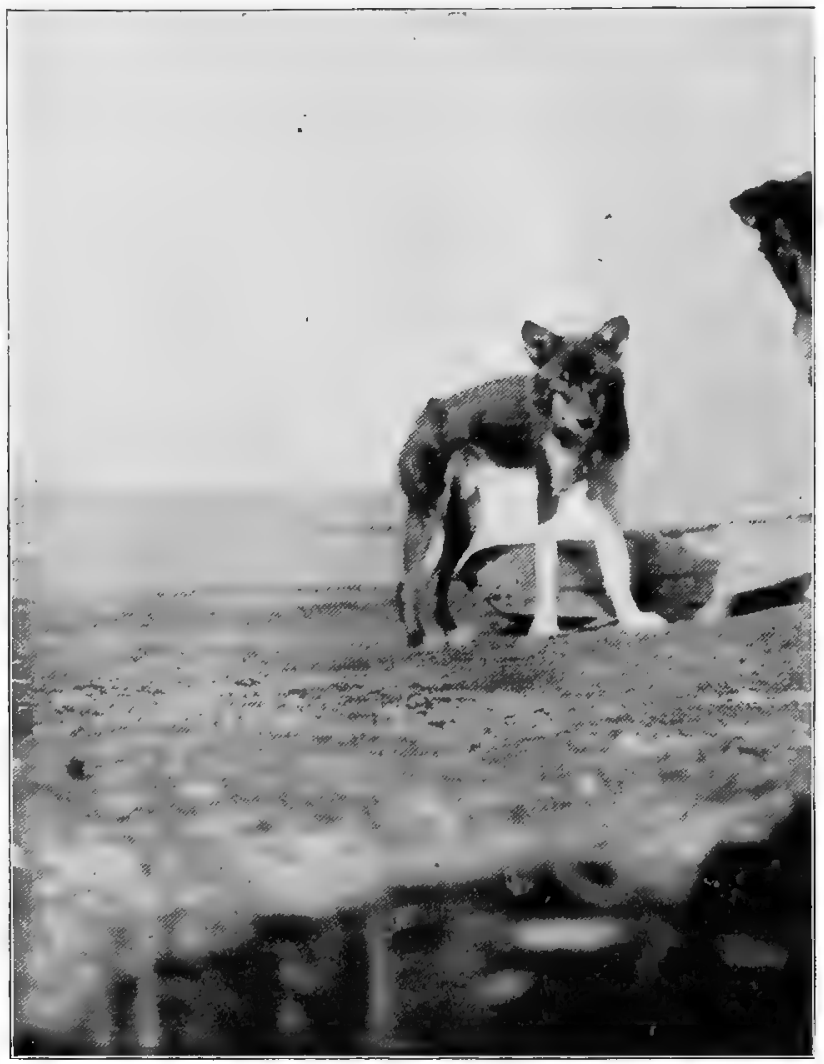

A GIDDE IN SUMMER CONDITION. 
ing in store for me. Our team was composed of four dogs, harnessed one before another. The Eskimo method of driving them in packs with a trace for each dog, is never employed by the Indians of the Canadian Northwest, who always drive them tandem.

Two of the team require special training. Tne leader, called the foregoer, sets the pace and changes his course at a word from the driver who, whatever his nationality may be, speaks to his dogs in the French patois of the North.

$H u$ and chac, anglicised to "you" and "chaw" are the words necessary to turn the foregoer to the right or left. The dogs are started by the command marche, though a few of the northern Indians still use the Athabascan word of command, - M'ni t-lă. The "sled dog," usually the heaviest in the team is trained to swing the head of the sled away from obstacles; it is important that he should be well trained when following a crooked track through the forest. A team which has been trained together is much better than a "picked-up team," as the dogs have a uniform pace, are less apt to fight each other, and will unite against all comers for self protection.

The Northern dog is always a draft animal. Regardless of age, sex or birth, his destiny is to haul. I have seen every variety, from a greyhound to a water spaniel, toiling painfully along in the harness. Most of them are of the wolfish breed known as Indian dogs, or, in the far North,_-giddés; these are smaller and more uniform in color than those kept by the whites. The latter are of a variety of colors, and all dislike work, particularly the yellow ones! The dogs of Mackenzie District are the largest and best trained of all that I saw in the North. They have been bred especially for hauling upon the established routes of travel, where weight, rather than endurance, is desired. Many of them have been disfigured by havfng their tails docked. The brush is a great protection to the nose and feet of the animals when lying curled up in the snow, exposed as they are to the lowest temperatures, and the loss of it through this senseless practice, causes much needless suffering. Some of them are tricky, making a great pretense of straining at the collar while really hauling very little. A few are willing workers, for which they are seldom rewarded; some are vicious brutes and have to be stunned by a blow upon the 
nose before they can be harnessed. All are accustomed to fight their way through summers of starvation and winters of ill-treatment, hunger and the whip. Frost or the teeth of foes mark their ears early in life. Their heads are battered with the whip stock or "willow"-any convenient club. Not unfrequently they are killed in harness and thrown out with brutal indifference by the wayside. The method of harnessing renders them more easily controlled than are the Eskimo dogs. A dog may tug wildly aside to escape the descending lash but he is too closely held to escape and is soon lying prostrate, his head under his fore-legs, howling until the driver's feelings are relieved or he is beaten into insensibility.

The Indian dogs haul much heavier loads than would be thought possible from their appearance. A team of four dogs which I drove the following winter, hauled a load of over five hundred pounds across four hundred miles of hilly country, without a track for the sled and with a short allowance of food. On November 6th, 1857, Mr. Lawrence Clark brought eight hundred and fifty-two pounds of meat into Rae with three dogs; this was on a level, beaten track. At Simpson, one thousand pounds were hauled by four dogs, but it was merely a trial on a good track to see if the team could haul half a ton, and three men were required to manage the sled. One hundred pounds for each dog is considered a maximum limit on hard snow.

The harness used by the Company in the Northwest may be either of imported leather or moose-skin. The Indians use moose- or caribou-skin, often without either buckles or the rod of quarter-inch iron for stiffening the circular collar. A band over the back holds up the traces and another under the breast is intended to prevent the dog from escaping from the harness which he sometimes succeeds in doing, upon catching sight of caribou or in struggling to avoid the whip. The traces, of three thicknesses of moose-skin, are long enough to allow a space of a foot between the dogs. The collars are surmounted by variegated pompons and the dog blankets or tapis, are elaborately beaded or embroidered. From one to one hundred bells are attached to the collars and back straps of the team; even the northernmost Indians manage to secure two or three bells for each dog. 
There are two sleds used, the cariole for passengers, and the flat sled for freighting. The sled itself, which is the same in both, is made of either birch or oak in the Northwest and of birch in the North. It is about eight feet long, sixteen inches wide in front, and fourteen behind. It is made of two or three boards curved upward in front to a height of two feet and then bent abruptly backward and downward; four or five crossbars strongly bound with babiche-a line made from green deerskin-hold it together; loops of babiche are placed along the sides of the flat sleds through which the lines of braided deerskin are passed in diagonal cross-lashings to bind down the load which is contained in a mooseskin "wrapper." The cariole has sides of moose parchment permanently stretched from the front to a board of equal height which serves as a back. Behind this, the sled projects two feet or more and affords room for the driver to stand when showing off the strength of his team, on his arrival at a settlement; or, upon a journey, without an accompanying flat sled, the fish for the dogs are piled there. The curved front allows just enough space to admit the tea and cooking kettles, placed one within the other and held in a bag fastened by a drawing string at the top. The cariole is a narrow portable bed in which the traveller may sit or recline at full length and sleep with comparative comfort, wrapped in robes and blankets. It is usually painted in as many colors as can be obtained.

Snow-Shoes. I made my first attempt at snow-shoeing on December Ist. The shoes were small and the snow soft so that they tended constantly to pitch forward and catch the upturned front under the snow. The disentanglement of a capsized snow-shoe in soft deep snow, is not easily accomplished. The victim fills his mittens with snow, wrenches his ankles, and breaks his snow-shoe lines in his efforts to right himself. Many who are not familiar with the use of Canadian snow-shoes think that one can move faster on them by taking a sliding step, which is, of course, a mistake, as they are not used with a skating motion at all. They are a positive encumbrance which must be raised at each step so that the body of the shoe may be clear of the surface. The step is therefore higher when the soft snow allows the shoe to sink; it is lengthened with large shoes which glide over each other so that the feet are laterally separated but little more than usual. 
The novice in the art of snow-shoeing is fortunate if he escapes the painful mal de racquette or "snow-shoe sickness," caused by the strain on the muscles and tendons of the lower leg, in carrying the unaccustomed burden attached to the ball of the foot. During the two winters spent in the North I was five times afflicted with this malady, but these attacks, except the first, were due to hardships which also affected my companions-natives-in a similar manner. At such times it seemed as if my ankle joints grated dry as I scraped along in the torturing dog-trot. Truly, the heavy hunting snow-shoe, or an ill-tied one of any sort "is a weariness to the flesh."

The snow-shoes used by the natives between the Red River and the Arctic Circle are of a different pattern from either the round framed shoes of lower Canada or the finer meshed snow-shoes used among the Loucheux Indians. They are narrow, pointed at the ends, and upturned at the front. The smallest, for use in walking on lakes, the Barren Ground, or in the sled track, are barely wide enough for the foot to rest clear of the frames, and are about forty inches in length. The largest hunting snow-shoes are sixteen inches in width by six feet in length. The frames are of birch, shaped and bent while green, dried over an open fire, provided with three to five crossbars and laced with babiche.

Tea-Drinking. The deep snow prevented the Indians from "making fur." Those at Cedar Lake who relied upon their catch of muskrats and martens for means to purchase flour were reduced to the verge of starvation. When relief was brought to one aged widow; who had been living for months upon the few rabbits which she had been able to snare, she made no complaint of hunger but loudly bewailed the fact that she had been without tea for several days. Tea is considered a necessity by all Northern Indians. They will cheerfully undergo the greatest hardships in the service of a "master" if supplied with tea and tobacco, but when these fail their courage also fails. After an experience of two years, spent in arctic or sub-arctic regions, I can testify to the efficiency of tea as a stimulant in a cold climate. It was wonderfully helpful in cases of extreme fatigue. No depressing effects followed its use though it was often consumed in immoderate quantities. The muscles as well as the nerves were acted upon and its 


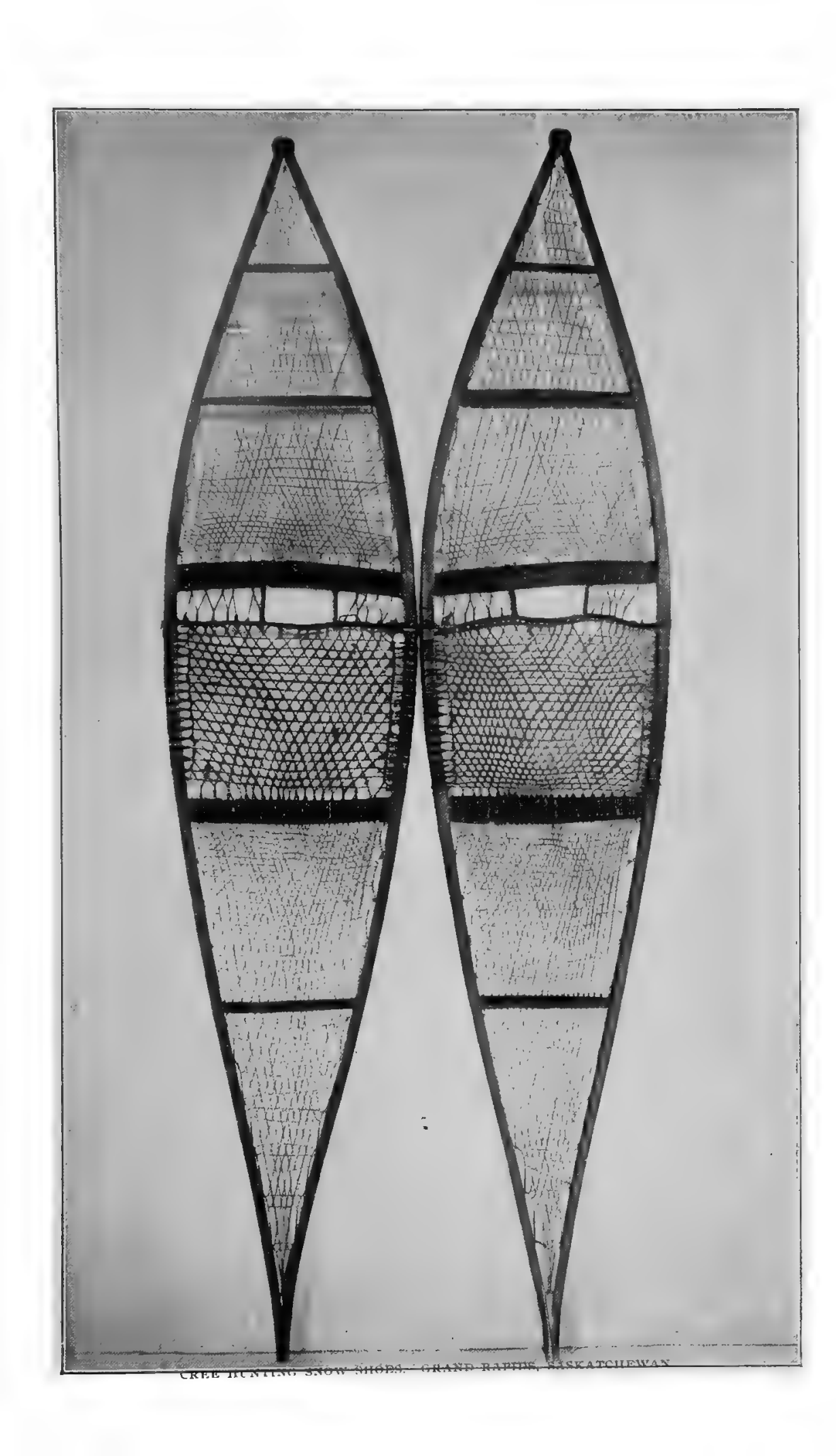



potency against the hardships which the arctic traveler has to encounter was fully demonstrated. With a meat diet it is far preferable to any other beverage; as the natives say, "it cuts the grease." 1

Jack Fiddler. On December 9th, I visited Selkirk Island, where two white men remained during the winter to oversee the Indian crews who put up the season's ice for the fisheries there. Crossing the channel, four miles in width, to the mainland, I found the cabin of "Old Jack Fiddler," a gray haired and bent little Englishman who lived there alone, subsisting upon the fish which were abundant in the bay before his door. I visited him to inquire about the Great Bear Lake country, where I thought of spending the following winter. Old Jack had accompanied Sir John Richardson, in 1848 , when that distinguished explorer descended the Mackenzie and followed the Arctic coast as far eastward as the Coppermine. This party, known as the "Arctic Searching Expedition," had wintered at the northeastern extremity of the Great Bear Lake in buildings they erected upon the site of Fort Confidence, built by Dease and Simpson in 1837 . He had also been a member of Stewart and Anderson's party which descended the Back River in 1855 . He had suffered much hardship upon the second expedition, which had passed through the Barren Ground during the season of heavy rains. The rheumatism there contracted, still afflicted him and must have made the life of the old man almost unendurable in that solitary cabin.

I had walked about twenty miles upon heavy snow-shoes on the preceding day and was glad to have an opportunity to ride back to the post with a party of Indians who were returning to the reserve with light loads. I had no furs or rugs, and indeed, could hardly have made myself comfortable with them, seated upon the loaded sled. Before we had accomplished a half of the fifteen-mile traverse I had become too cold and stiff to run and too stupid and indifferent to realize that I was quivering and shaking in the intensely cold wind that swept across the

1 Admiral Inglefield strongly commends it. "Seamen with me up the Wellington Channel, in the arctic regions, after one day's experience of rum drinking, came to the conclusion that tea, which was the only beverage I used, was much preferable, and they quickly derived great advantage from its use while undergoing hard work and considerable cold." Quoted by Reade, Tea and Tea-Drinking, p. 68. 
lake and that I ought to have walked and disregarded the opinions of the men, if I did not wish to prepare myself a future as unpleasant as that of Old Jack.

My driver stopped every mile or two to whip his dogs. Not content with bringing down the lash with all his strength he clubbed them with the whip handle until the blood appeared in spots on their heads and ran from their nostrils. 


\section{CHAPTER II}

\section{THE SASKATCHEWAN NATIVES}

URING the months of January and February, I893, I laid aside the shotgun and occupied the time in studying and packing the collection, and in visiting the natives.

All the Indians at the post and a few from the river reserves were engaged in the ice harvest from the middle of November until New-year. The most of them were at Selkirk Island, but about twenty were at work at the mouth of the river under the direction of Mr. McLean, the genial clerk of the Grand Rapids post. They gathered at daybreak at the ice houses each man with his sled and dog team. They presented a grotesque appearance as they dashed up, standing upright upon the swaying flat sled, cracking their whips at the lean and snarling curs. They were dressed in white man's clothing except the comfortable and more suitable moccasins and the capote of blue cloth manufactured expressly for the Indian trade.

They ate their lunch of fish out of doors and seemed as indifferent to their own comfort as to that of their dogs, that were allowed to lie in harness and shiver in the snow all day. After nightfall they all came to the Big House for the day's wages, or those of the day's to come, if they could get a little "debt"credit. They filled the little office and sat crosslegged upon the floor, talking and smoking, while the clerk took one man at a time into the store and weighed out a pound of bacon, a little flour, etc., to the amount of his day's earnings.

The stores are never heated in winter on account of the vacillating nature of the customers, who would consume too much time in making up their minds about their purchases, and in gazing at the tempting display of beads and ribbons if they were not literally frozen out. One or two violins would, be kept going constantly for the two or three hours that they occupied 
the office. Every French metis and several of the Indians could play jigs and reels which they rendered with variations ad libitum. Sagames ("Mosquito"), a tall Indian with small skill and a large fund of humor, usually gained the most applause by handling the violin as if it were a new toy, he had then met for the first time and which through his manipulation evolved various discordant squeaks until it suddenly burst forth in the lively strains of the "double jig."

A Metis Wedding. One of the most important social events of the year was the marriage of the daughter of Antoine Chartier, an old engagé. The announcement was made and arrangements begun to make it an affair of unparalleled magnificence. The reserve was upon the tiptoe of expectancy, as Old Antoine was known to have a little credit at the store. On the day preceding the important date the bride had not yet made up her mind whether to marry or not, so that postponement was necessary. After a few more postponements, Annette decided to accept Benjy's proposal and the festin was prepared. Being a stranger to their customs, I was invited to attend; the mere announcement was sufficient invitation to everyone else on the reserve.

The guests came, not with presents, but with a great yearning for the free dinner. They would give the young couple a start in life by eating the entire fortune, then upon the tables, of both families. An ox had been killed, and two hundred pounds of flour baked into bannocks. The tables were loaded with boiled and roasted moose-meat and beef. There were plum puddings and rice puddings, in which the principal ingredients were raisins and currants. There were also a few pies, and cranberry sauce and strawberry and raspberry jam in abundance. Tea in unlimited quantities completed the menu. The dinner was ready at four in the afternoon. As soon as one tableful was temporarily satisfied, another lot from the group outside the cabin would seat themselves.

At eight o'clock the clatter of the fiddler's feet upon the loose boards of the warehouse floor at the old steamboat landing indicated the opening of the ball. The "orchestra" wore a pair of heavy "English shoes," as the imported article is called, the rub-a-dub of which, in beating time, drowned the music and the soft shuffle of the moccasined dancers. The 
"hall" had a few benches arranged for the occasion along the walls, and was illuminated by half a dozen candles. It was exhausting work for the violinist to keep both feet going for any length of time, so that the violin soon changed hands. Before morning nearly every man present, including the groom himself, had taken his turn. Round dances were not indulged in. The jig was the most popular dance as it gave great opportunity for the display of individual skill, in the men at least, who stamped, shuffed and pirouetted about their almost motionless partners. One young fellow, about six feet in height, was of very slender build and his legs seemed to vibrate in unison with the violin strings; his performance would have received applause before any audience, nor was he without honor in his own country. The men wore their hats throughout the evening and usually had pipes in their mouths. In forming a set for a reel, they chatted and smoked for awhile, until, as if suddenly remembering what they were there for, each selected his partner and crooked his finger at her as a signal; whereupon she took her place beside him; if she hesitated she was assisted - forcibly - to the floor. The bride appeared in three different costumes during the evening. The first, of course, was the wedding dress, according to the custom of the country a present from the groom; in return, the bride had made a pair of fine silk-worked moccasins for him. The ball closed with the kissing dance, a ceremony I did not stay to witness.

As Antoine's supplies were not quite exhausted the feast and dance were repeated on the following evening. There was very little liquor obtainable, and the dancers were comparatively quiet, except for a few yells by which they gave vent to their exuberant feelings, while in the violent contortions of an eighthand reel. The young women were accompanied by their mothers and when not engaged in dancing, remained seated upon the floor in a separate group.

New-year's day is the principal holiday in the calendar for the Indians of the North. The wedding "festin " reduced one or two families to the point of starvation, but at New-year the whole settlement became bankrupt. The Indians have readily adopted the custom, somewhat modified, of the whites, in observance of the day. They make calls in the morning and gorge themselves with food and great quantities of tea; the 
afternoon is spent in dog-racing and football, and in the evening occurs the dance of the season. New-year's day is called O-che-mi-ki-se-gă or Kissing Day, as it is the custom to kiss everyone on that day, young and old. This would be more agreeable if one were allowed a little more discretion in his choice.

In the morning we were visited by a party of boys with sacks in which to carry away cakes (bread). No sooner were they gone, than a dozen muskets discharged outside the door announced the arrival of the men, who were given cakes, or meat and tea, at every house. They were followed by the women who usually finished whatever remained. In the evening at least a hundred people gathered in the cabin where the dance was held and the room was so crowded that the dancers had very little space left them.

Every cent of "debt" that can be secured is spent upon flour, bacon, tea, rice, raisins, and sugar, and for one day Peter Mink is happy even though he starves for the next six. Each woman must have a new dress and each man appears in a pair of new silk-worked moccasins.

Marriage. Early marriages are the rule. Policy and business considerations, here as elsewhere, have their influence upon the match. Peter Mink must have someone to dress mooseskins and make moccasins for him. Mary Rabbitskin is a burden the paternal Rabbitskin would gladly relinquish to the care of Peter, if he is a good hunter. The affair is managed by the "old wives," as the married women are called.

Just before I arrived, Grand Rapids had been profoundly stirred by its first breach of promise case. The defendant's mother urged him to marry the plaintiff but it was only after a long course of nagging that he consented. At the appointed time his heart failed him, the sacrifice in complying with his mother's wishes was too great. He took to the bush, flatly refusing to fulfill his promise. Day after day the bride awaited Donald's coming and day after day the truant bridegroom betook himself to the muskeg, until the plaintiff presented her grievance before the Indian agent, praying for heavy damages. The magistrate imposed a fine of twenty-five dollars and ordered the defendant to leave the reserve. His only excuse was that he loved another. Two months later he married a third girl. 
Houses. The peace-loving Wood Crees have readily taken up a sedentary life. They remain in cabins upon the reserve throughout the year, with the exception of a few who move down the lake during the fishing season or spend the winter in pursuit of game. Before he was "civilized" the Cree moved his lodge of deer or mooseskin from place to place, so that his surroundings were always fresh and clean. His habitation is now fixed, but so are the old habits, and the filth simply accumulates. There is but one reserve in the Lower Saskatchewan region that has any reputation for cleanliness-and it is occupied by "heathen" Indians. Each house has usually but one room. The roof of poles is covered with earth; this does very well in winter, at other seasons the rain soon washes through. Roofs are sometimes made of spruce bark, but these are not so warm in winter. The door is closed by a bar, the latchstring being "always out." You enter without knocking, of course, and look upon a small cheerless apartment. There is a rude fireplace with a chimney built of grass, stones and clay; the floor is rough and not clean; there is no ceiling. Some have a few chairs, dishes and a stove, and stationary bunks against the walls, others have no furniture whatever. The two dirty gray blankets which cover the family at night are aired during the day upon the nearest tree. They sit upon the floor when eating and in that position what need is there of a table?

In summer they sometimes abandon the house, especially if a death has recently occurred in it, and live in the ordinary conical lodge made of canvas. While there is yet open water some who are trappers go with their families to the hunting grounds and construct a lodge-shaped winter dwelling of split poles, which, when covered with earth and snow, is quite warm and comfortable. Others are covered with spruce or birchbark, or, if the owner has an antipathy towards manual labor, the framework of the poles is covered with sacking, blankets, rags, and loose strips of bark. The best lodges for mild weather are made of ducking, forty yards being required for each. A piece of sacking or old blanket is hung over the low doorway; a stick, a little longer than the oval opening, is tied to the bottom of the "door," to keep it spread, prevent it from swinging in, and to serve as a handle in lifting the door flap to 
enter. Within, an open fire burns in the center beneath the broad smoke hole at the apex of the cone. The floor is carpeted with spruce boughs. The occupants do not stand up inside the lodge as their heads would then be in the smoke, but sit crosslegged upon blankets around the fire.

Sir Francis Drake in describing the Indian lodges near Golden Gate, says: "Their houses are digged round within the earth and have from the vpper-most brimmes of the circle clefts of wood set vp and ioyned close together at the top, like our spires on the steeple of a church; which being couered with earth, suffer no water to enter, and are very warm; the doore in the most part of them performes also the office of a chimney to let out the smoke: its made in bignesse and fashion like to an ordinary scuttle in a ship, and standing slopewise: their beds are the hard ground onley with rushes strewed vpon it, and lying round about the house, haue their fire in the middest, which by reason that the house is but low vaulted, round and close, giveth a maruelous reflexion to their bodies to heate the same."1

This description, written in 1579 , is equally applicable to-day. Warburton Pike, writing three hundred years later, says, "There is no better camp than a well-set-up lodge with a good fire crackling in the middle." 2 When the temperature falls to sixty degrees below zero a "maruelous reflexion" is needed to "heate the same." The adult inmates are lightly clothed and the children half naked. At night there is but one three-point blanket for each person. The fire soon goes out and it is then a question of endurance. In this battle with the frost, the Cree wraps his blanket around his body and head, leaving his feet exposed.

Dress. Capotes are worn in winter; these are light, hooded frock coats, of fine woolen cloth, unlined and ornamented with a double row of brass buttons. This is the "fine-cloth capote" so dear to the heart of the voyageur. A capote of cheaper and coarser cloth is worn by the poorer class. but the rough cloth is not impervious to the wind and snow. The hood protects the neck and head from the winds and from masses of snow dislodged from the trees in traversing the bush. They are short and do not obstruct the limbs in running on snow-shoes.

1 The World Encompassed, p. I2 1

- Barren Ground of Canada, p. 37. 
Belts are worn at all seasons. The best are called l'Assumption belts; they are woven from heavy threads and are from four to six inches wide and eight to ten feet in length. They are girded around-not above - the hip bones. The belt is used as a tompline or packing rope, to mend dog harness, or wherever a line is needed. The cord fringe at the ends usually has a finger ring and the key to the wearer's cassette tied in it. The belt is wound twice around the body and tied in front, leaving the long fringe hanging. As they are variegated with all the colors of the rainbow they form a conspicuous part of the apparel of the Indians and métis.

Imported caps, or Canadian tucques, are worn in winter. In summer the costume is that of civilized man except for the belt and moccasins. The women wear dresses of light, though expensive material, which is wholly unsuited to their needs. They endure the greatest hardship and exposure without a murmur. Winter moccasins are made large enough to contain a square piece of duffel or old blanketing in lieu of socks. With heavy duffles I had no difficulty in keeping my feet warm on the coldest days; even when they were bound with the snowshoe lines I never froze them. No matter how cold it may be the moccasins become damp from contact with the snow and must be dried at night. When wet, they wear away quickly; a wet, stony trail will wear holes in new moccasins in two hours. They are made of mooseskin with deerskin or cloth tops, which fold around the ankle. A small piece of snow-white deerskin, bordered with colored horse hair and embroidered with silk and beads, is placed over the instep. There is very little beadwork done at present at Grand Rapids and I did not see anything at all comparable to the beautiful transparent beadwork of the Ojibways.

Treaty. In I875 Lieutenant Governor Alexander Morris, and Hon. James McKay, commissioner and interpreter, went among the Crees and Sauteux of Lake Winnipeg, proposing that a treaty be drawn up between the Great Mother and her Red Children, whereby the country was to be opened to white settlement and the Indians placed upon reserves as wards of the government. The old, blind chief, Peter Beardy, and Joe Atkinson, two intelligent half-castes, I found could speak English fluently. Both were fond of repeating the story of the 
governor's visit. "This is the way it was laid down to the Indian" said Old Joe. "I will give you cattle, horses, sheep, hogs, and poultry. If you desire them, I will furnish you with a carpenter, a blacksmith, and a farmer, that you may learn these trades. I will give you a doctor and a school-teacher. I will provide you with scythes to cut grass, tools and machinery to till the soil, twine from which to make nets, rations of food and an annual gift of money. We will care for you as if you were our children. As long as the sun shall shine and the water run, this promise shall never be at an end."

The Indians made no demands but signed the treaty without protest. One of the leading men of the band asked that a copy of the treaty be made at once and left with them. "We have no time now," was the answer. "We are using a borrowed boat and must push on at once." The chief brought a copy of the treaty to me. It was wrapped in an old apron with a few letters and a quantity of aromatic leaves. This document stated that cattle would be given to the thirty families on the reserve; a school-teacher would be provided and they would be furnished "once for all" with plows, hoes, etc.; $\$ 500.00$ per annum was to be expended in purchasing ammunition and netting twine for the reserves contained in Treaty Number Five, nearly fifty in all, embracing an area of about one hundred thousand square miles. ${ }^{1}$ For a number of years this has not been sufficient to provide one-third the twine necessary to make one net for each family. The rations issued amounted anually to eight pounds of flour, a little bacon, tea and tobacco for each man. The attempts to make the Crees self supporting have not been very succcessful.

Cattle to the number of twelve head, were placed on the reserve twenty-five years ago. A few years later a second lot were received, nearly all of which died of starvation during the next winter. In 1892 seven more arrived and these, too, were dying when I left the post in February. Hay was scarce and of poor quality. It was cut from the marshes which were overflowed by the lake in stormy weather. The severe gale previously mentioned destroyed the diminutive stacks of hay which had been left to be hauled by dog teams during the winter. The Indians are not allowed to sell their cattle, to kill

1 Begg, Alex., History of the Northwest, Vol. II, app., p. 44 . 
them, or to hire out their oxen to the whites. They had but one ox that could be used in hauling and the poor beast had a hard time of it. They said, "We do not desire these cattle, we have no one to show us how to care for them. Why should we raise cattle for the Indian Department, anyway?" In the spring when the supply runs low, they rob each other's hay caches and even steal from the Company's stack at the post.

The reserve is simply a wooded swamp with a narrow strip of dry land along the river and yet they were told that the four miles of reserve would not include the muskeg but would be all dry land.

Medicine. The Government furnishes a stock of medicines which are dispensed by the Company's clerk. Castor oil is the most popular medicine and children have been known to drink a small bottleful thinking it to be fish oil of rather extra quality. The Company sells a patent cure-all made in "America" as the United States is called in that region, in which the natives have implicit faith. It is used whenever obtainable, whether it is required or not.

The clown, Sagames, a few years ago, conceived the idea that a stone was forming in his chest and that any over-exertion on his part would be the cause of his immediate death. Notwithstanding the fact that Mrs. Sagames and the children were starving, he persisted in keeping his bed throughout the winter but was "brought round" in the spring by a wonderful medicine prepared by the post keeper. It was a mixture of the dregs of some old medicine bottles, with Worcestershire sauce and cayenne pepper as the principal ingredients. At nearly every post that I visited such cures of imaginary diseases were reported.

Old Antoine was the most skillful doctor in the settlement. He showed me about thirty deerskin bags containing herbs from which medicines to cure every disease might be concocted, and assured me that if it were summer he would show me the plants and how to gather the roots or leaves. He said that he had cured cases of cataracts in the eyes of dogs, but had never tried his remedy upon a fellow-being. ${ }^{1} \mathrm{He}$ took the ends of long bones and burned them, reducing the ashes to a

1 The Eskimos are said to remove "specks" from the eyes with calcined bones. (Bompas, Northern Lights, p. I50). 
fine powder by pounding on deerskin. This was blown into the affected eyes, two applications being sufficient to produce a complete cure. A doctor had visited them four times in eighteen years, "as a bird passing," the chief said. Every man, woman and child, receives an annual "treaty" of five dollars in cash. This is taken in "debt" as soon as the last gratuity is paid. If a death occurs the head of the family who has "taken up" the annuity refuses to pay the Company when he receives the money. He thinks that an act of Providence annuls the obligation to pay. Not only do they take up the next year's annuity for the whole family but they even ask for "debt" on account of an unborn child. They remember the verbal promise that "all shall be treated alike" and are well aware of the fact that the surrounding tribes are treated far better than they; that the Plain Crees, for example, receive weekly rations, and have blankets and other necessaries furnished them.

School. In January, I 893, I visited the school maintained by the government for the education of the children of treaty Indians. The building had been erected by the Indians themselves; the walls were warped and cracks gaping. Holes in the roof admitted the sunshine or the storm. The door hung "slopewise," the floor was rough and broken. The register of the previous quarter contained under the head of "Remarks," the following protest: "The Department's attention has been repeatedly called to the deplorable condition of the school building which still remains in the need of repairs. It is not fit to house cattle in." There were no desks, the children sitting upon benches and keeping their books beside them. There were twelve slates for thirty pupils. They seemed to be quite as mischievous as white children, and their attention was easily distracted from the work in hand. On being asked the day of the week by the missionary teacher, one young hopeful answered January, another said it was "fifty-two weeks." Yet the instructor assured me that they had been taught the days of the week almost daily for months. One boy about fourteen years old read from the second reader and translated readily from Cree to English. He also had a fair knowledge of the elementary rules of arithmetic.

The instruction is oral aided by slates and charts. The children are taught numbers, reading and writing, spelling, 
geography, grammar, (sic) vocal music, and especially the English language. Their training appeared to the best advantage when they sang hymns in their mother tongue. They also sang in English hymns wholly unintelligible to themselves and nearly so to the listener.

On the playground I found the boys engaged in a game of football. The "ground" was a little opening among the pines surrounding the building, where three feet of snow had been packed firm and hard by the tread of many moccasins. The ball was made of rags and about six inches in diameter, irregular in shape and very light, but not too light for the feet of the players protected only by moccasins. A genuine "rush" would have resulted in the total demolition of the wearing apparel of the participants, who wore the cast-off tatters of their elders.

At noon each pupil was given two hard-tack biscuits for lunch. This was supposed to be sufficient inducement to bring them to school. Many of the children ate the meat or fish they had brought with them and carried the hard-tack to their parents.

Mission. About twenty years ago an Episcopal mission was established at Grand Rapids, then included in the diocese of Rupert's Land. The Indians built the church and missionary residence, so the buildings are their own and not the property of the church as other missions, where the land is set apart by the government. The church is a barn like structure of hewn logs, with very little furniture within and no decoration whatever. The bell is hung upon a tower apart from the building. The manse is a low roofed cabin, very cold in winter and very muddy in summer when the rain washes out the clay with which it is chinked. The missionary receives a small salary from the church missionary society of England, which also provides Bibles and hymn books, printed in the Cree language. Both the syllabic ${ }^{1}$ and the Roman characters are used in these publications, and nearly all can read. They possess a natural talent for vocal music and their language being a musical one ${ }^{2}$ the choral service is very pleasing to the ear.

They cannot comprehend sectarian differences and do not

1 A syllabic alphabet was invented by a Cherokee Indian named George Guess, in 1826 . A system of syllabic characters was independently devised by James Evans, a missionary at Norway House, on the northeast shore of 
understand why their minister objects to their children associating with those of the Roman Catholic Pierre Jean François, who live on the left bank of the river opposite the reserve.

The Saskatchewan. The Saskatchewan, or as it is called by the natives-Kissiskatchewan (Swift Current), is said to drain a larger area of fertile land than any other river in the British Empire. The melting snows in the Rocky Mountains maintain a sufficient depth of water to enable light draft steamers to run as far as Edmonton on the North and Lethbridge on the South Branch. The two branches unite about four hundred. and fifty miles above the mouth. Like nearly all the rivers of the Northwest and North, the Saskatchewan has not only a "swift current" but also many rapids. The largest of these, the Grand Rapids, are within five miles of the mouth, where the river breaks through a series of limestone ridges

Grand Rapids was the scene of an interesting chapter in the history of the conflict between the fur companies in the early part of this century. During the month of July, I8Ig, Gov. William Williams of the Hudson's Bay Company, with a number of clerks and engagés and a force of discharged soldiers of the DeMeuron's regiment, there met the brigade of boats bringing down the Northern furs of the northwest Company. His men were armed with muskets, two four-pound guns, and a number of swivels from Hudson's Bay. The last mile of the rapids. could not be ascended by loaded boats so a trail had been cut, from a little cover below the gorge, through the heavy forest to the smooth but swift water a mile above. In running down, the

Lake Winnipeg. This Cree syllabary was perfected in $184 \mathrm{I}$. It has been described at length by Dr. McLean in his work entitled, Fames Evans, Inventor of the Syllabic System of the Cree Language, 1890 . The system is based upon the phonetic principle, and each character represents a syllable, thus-

$$
\begin{array}{llll}
\neg \mathrm{m} \overline{\mathrm{a}} & \Gamma \mathrm{m} \overline{\mathrm{e}} & \mathrm{J} \mathrm{mo} & L \mathrm{mä} \\
\eta \mathrm{cha} & \Gamma \mathrm{che} & \mathrm{J} \text { cho } & \iota \mathrm{chä,} \text { etc. }
\end{array}
$$

Only thirty-six characters are required for the Cree language.

Archdeacon McDonald, of McPherson, has invented a more cumbrous system for the Loucheux language, which employs the Roman letters, but contains about 500 syllables, which "notwithstanding the apparent difficulty, some of the Indians have learned in a fortnight." Dr. McLean in a letter to J. C. Pilling, Biography of the Athabascan Languages, p. 59.

Compare Petitot: "La lang crise est douce, sonore, musicale et très scandeé. C'est l'italien du Nord-Ouest." Legends, p. 446. 
bourgeois of the Northwest Company walked across the portage and were taken prisoners by the superior force lying in wait at the cove. These gentlemen were confined for some time on a small round island-now called Prisoners' Island-in the middle of the stream, and then taken to York Factory, where they were treated with great cruelty.

In the latter part of the eighteenth and the beginning of the present century, six to eight hundred men were sometimes encamped at this portage. Then, the narrow lane cut through the forest was worn by the feet of dark-skinned porters. Now, the silence is unbroken save by the chickaree and the impudent whiskey jack, and the path is grass grown. The little clearing contains a few mounds with crumbling crosses that mark the resting place of a few "unknown."

During the summer months the rapids are frequented by double-crested cormorants, white pelicans, and large numbers of ring-billed gulls.

In 1877 the Company built a tramway, nearly four miles in length, from the steamboat landing below to the river a mile above the head of the rapids, at which point dwellings and warehouses were built. Four miles above are the Roche Rouge Rapids; river steamers ascend these by the aid of lines and donkey engines. The heaviest rapids besides the Grand Rapids, are those of the Demi-charge, thirteen miles above "The Portage," as the buildings at the head of the tramway are called. At the foot of Demi-charge, lies Calico Island, so named in I872, when the first river steamer went to pieces in the rapids and her cargo, containing a large quantity of calico, was spread out upon the island to dry. Seven miles above the Demi-charge Rapids is another stretch of rough water and beyond this the short and narrow "steamboat channel," leading out of Cedar Lake. On the south bank, near the rapids, two or three crumbling chimneys mark the site of a long abandoned trading station called the "Flying Post." 1 In 1892 two Indian cabins stood upon the lake shore near the channel, affording a convenient shelter for passing travelers, as they were about halfway between the posts.

Fifteen miles from the Narrows, the boat route turns sharply

${ }^{1}$ Hind calls this station "Cedar Lake House, a winter trading post of the Hon. Hudson's Bay Company, lately established," etc. Report on the Northwest Territory, $185^{8}$, p. 76 . 
to the north around Rabbit Point, a muskeg terminated by reefs and shoals. On the 2Ist of November, I8I9, Mr. Benjamin Frobisher, of the Northwest Company, died from starvation and exposure at this point. Accompanied by two Canadian voyageurs, he had made his way from York Factory-a distance of over five hundred miles-only to die there within two days march of Moose Lake House. He had been one of the party captured the preceding June at Grand Rapids, but had escaped from captivity, and after months of suffering and hardship reached Rabbit Point. His companions, with nothing but moose leather to eat, had carried him from the Narrows, but their strength gave out and he was left at the Point, while they sought assistance from the post. A rescuing party found his remains, burned by the fire into which in his weakness he had fallen while trying to renew it. ${ }^{1}$

The Winnipeg country is said to have been visited by Canadians in the latter part of the seventeenth century. Joseph La France, in $1740-42$, was the first to traverse the intricate network of lakes and rivers connecting Lake Winnipeg with Hudson's Bay. It was not till I774 that Samuel Hearne reached the Saskatchewan and established the post at Cumberland; while the first Red River post of the Hudson's Bay Company was established in I799.

For over two hundred years the Saskatchewan was the only practicable route to the Athabasca River and the Far North. After the consolidation of the fur companies, in I82I, goods were brought in by way of York Factory. The boats used by the company were called York boats because of their annual journey down to York. They were long and open, the rake of bow and stern being alike, guided by a heavy sweep passing through a ring in the sternpost. They were manned by a crew of six or eight oarsmen and a steersman. They were capable of carrying ten tons, would stand rough usage, and were easily repaired. With a full wind, a sail quickly improvised from tarpaulins allowed "a spell" to the crew, who usually worked to the limit of their endurance in their haste to reach their destination, before the short summer closed. These brigades were made up of the Canadian voyageurs, and Cree, Sauteux, and Northern Indians.

${ }^{1}$ (Masson, G. R.), Les Bourgeois, Vol. II, p. I79. 
The long and dangerous boat route to York Factory was abandoned when the railway reached Red River. The Saskatchewan itself found its occupation gone when the "Northern Outfit" crossed the plains by rail to Calgary, and later to Edmonton.

I am indebted to Mr. Angus McLean, clerk in charge at Grand Rapids since 1878 , for the following information concerning the river traffic. Saskatchewan freight was carried in York boats until I874, when the steamer "Northcote" was built. In the summer of 1877 she made four trips to Edmonton. She was of too heavy draft for the river and now lies at Cumberland. The first river steamer was built at Grand Rapids in I872, and was wrecked at Demi-charge Rapids on her first trip, before she had gone twenty miles. She had not yet been named, being known simply as "the first boat." The "Northwest" was built at Grand Forks, North Dakota, and came to the Saskatchewan in 1882 , passing the Grand Rapids with ther machinery in place. She still makes one or two trips each year, supplying the river posts of the Hudson's Bay Company. In 1882 another steamer, "The City of Winnipeg," intended for river traffic, was wrecked near Long Point while being towed across Lake Winnipeg. The steamer "Manitoba," also coming from Red River, as the settlement between Winnipeg and the lake is called, was taken through the Grand Rapids without her machinery. Her career was very brief, terminating at Prince Albert, where she was crushed in the ice. In 1877 the steel steamer "Lily" was built at Grand Rapids. She proved to be of too heavy draft and was in use for only a short time. These were all stern-wheel steamers drawing, when loaded, from two to three and a half feet of water. The "Marquis" was the largest carrying two hundred and fifty tons, the others two hundred and twenty each.

Ooskanatchet. Early in February I visited old Ooskanatchet, at the Narrows. He was said to know more Cree legends than anyone else in that region, and I had already exhausted the stock of myths at Grand Rapids. I found the old man very talkative, but it required liberal gifts of tea and tobacco to induce him to speak of the mythical beings in whose existence he had implicit faith; he was the only Indian on the Lower Saskatchewan who had not accepted christianity. He said that 
the Pauguk, or Death Demon, had appeared to him, a sign that his course was nearly run. He and his "old wife" made an image of Pauguk for me of substantial birch wood and mooseskin. This creation, dressed in mooseskin and daubed with paint-representing the most terrible of all spiritual powers, preceded me on the voyage home, where, upon my return I found it temporarily entered in the museum catalogue as "Indian Doll." Ooskanatchet gave me his peace-pipe-with the request that it be preserved in the museum, which I had described to him. The bowl, of fine-grained sandstone, he had obtained, perhaps a half century before, from Red Deer River, west of Lake Winnipegoosis; the stem was from a shrub called nepemenana. The old man solemnly and ceremoniously filled and lighted the pipe, then turned the stem towards the four cardinal points, towards the zenith and nadir, took two or three puffs, and then handed it to me. I did not wish to offend by refusing to take two or three whiffs, but I did not use tobacco and not for all the tribal wampum would I have smoked that nicotine-soaked uspwahgun, filled with negro-head tobacco.

His medicine drum was very similar in shape to an old fashioned dasher churn. It was of birch wood, a foot in diameter by eighteen inches in height. The head was of mooseskin parchment dampened and stretched when used. The drumstick was a birch rod bent at a sharp angle, as shown in the figure. The drum is accompanied by a rattle, formerly made of mooseskin parchment with gravel enclosed, but the advancement of modern civilization and the old man's inventive genius had substituted a tomato can containing a few grains of shot, with a handle attached by thongs.

He warned me not to take whiskey jack's or crow's eggs during my spring collecting. No matter how valuable they might be, I would certainly have bad luck if I tampered with the nests of these birds. Old Antoine, who interpreted for me, said that he had once found the nest of a whiskey jack or Canada jay, and since then several of his children had died; this proved the matter conclusively.

Ooskanatchet was unusually liberal in his gifts and one might have inferred that he anticipated a speedy departure from this life. I had learned not to be too profuse in my thanks under 


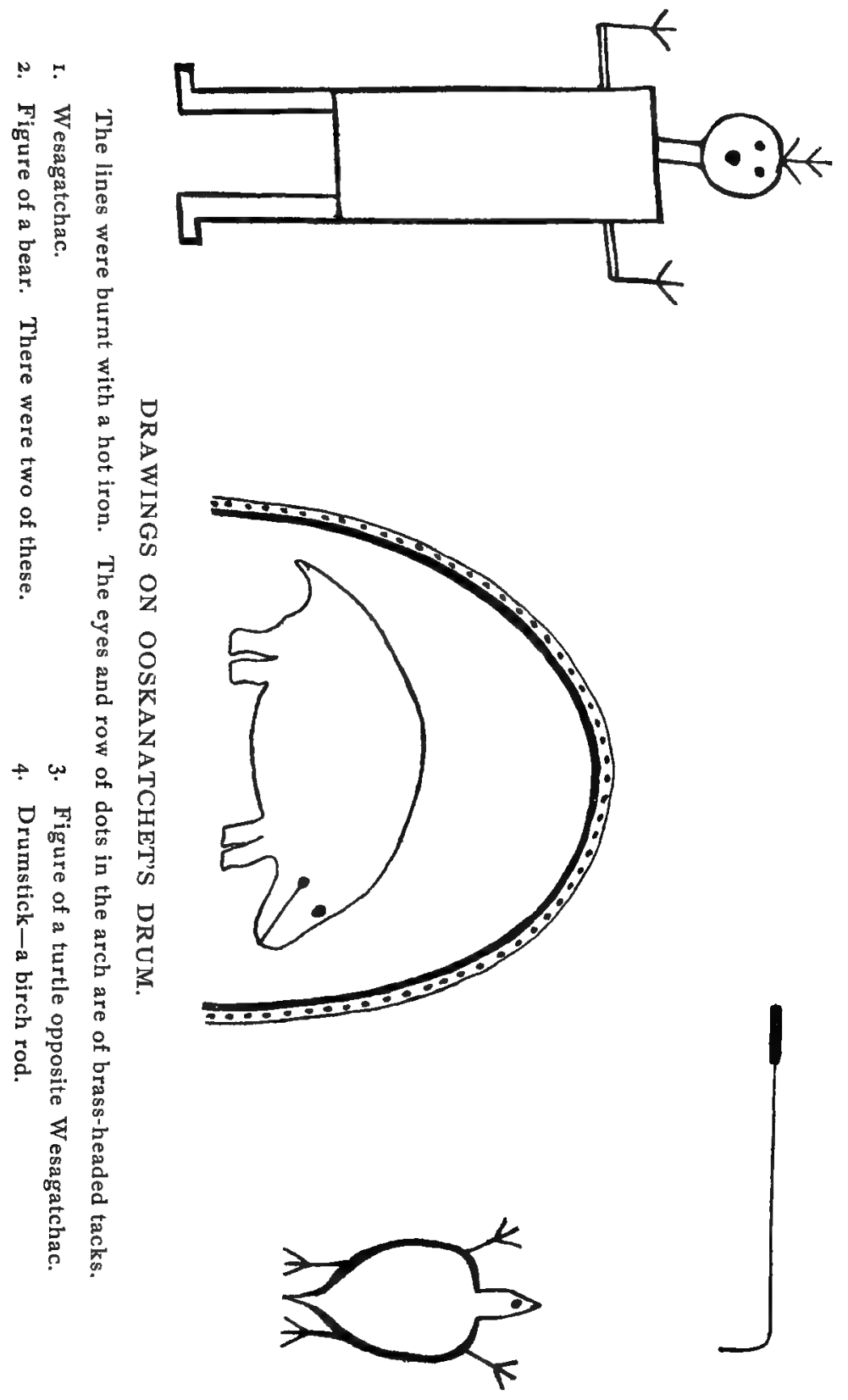


such circumstances, as it all usually resulted in a request for a "present" of tea and tobacco. I promised to pay for the articles received when I returned to the store, and then his scheme was disclosed, showing that his faith in Pauguk had less to do with the disposal of the pipe than had his appetite for butter and milk. He was allowed to live at the Narrows by special permission, and received his annuity at Chemawawin. $\mathrm{He}$ wished me to write a letter to the Indian agent in Winnipeg asking for two cows to be kept at the Narrows. The letter was written when I reached the city, but, I fear, with less diplomatic skill in its composition than the old man would have displayed.

Ooskanatchet had a family of four boys on whom he had bestowed peculiar names, perhaps with a desire to advertise his medicine "business." Ammogabo, or Aleck, the best moose hunter in the country, was the oldest. Another was called Owatches, or child; a third, Kemootisk, Thief, and the last bore the suggestive name of Wihtigoosis, Little Cannibal or Little Devil.

Sturgeon were abundant in the lake before his door, and the swift current prevented the ice from forming for any length of time in the river channel, so that nets could be set during the winter. The surrounding forest contained caribou and moose, and a few fur bearing animals, by trapping which, and by the sale of sturgeon and moose meat, they lived very comfortably. I tried to engage Aleck for the trip to the Far North, but his father and mother were afraid that their food supply would fail if that faithful provider left them. They could not comprehend the fact that I would arrange to have regular rations given them at the post. They were also afraid of the influence evil spirits in strange lands might have upon their boy, though Aleck himself was quite willing to go.

In returning to the post next day we had to cross the river where the current had worn the ice very thin. The ominous gurgle from the hummocks of snow and the black patches of open water showed the dangerous character of the frail bridge, half a mile in length. We were accompanied by the Thief, who was on his way to the post with a sled loaded with sturgeon. Antoine could not think of traveling for four hours without "boiling the kettle," so we stopped and melted snow for tea and fried a little bacon. The Thief had brought his kettle of 
tea nearly to a boil when the burning sticks fell beneath it and it was all spilled. Not gaining wisdom by experience he allowed this to happen a second time, after which I did not wonder that Ooskanatchet was afraid to depend upon him and the Little Devil for support.

Tea Kettles. The tea kettles_"copper kettles"-used in the North and Northwest are tin-lined copper pails having a close fitted lid with a ring riveted in the centre. There are no seams to melt in the intense heat of a winter camp fire, and they are sufficiently heavy to withstand the hard usage of camp life. The smallest hold but one pint. The two quart size is the one used by two men traveling together and one filling is never enough to satisfy their thirst.

Provision. In summer, in the Northwest, the bread is baked en route. It is made of flour and water only, no leavening agent being used. The dough is made very stiff and is worked for some time. It is kneaded into flat circular cakes of a size to fit the frying pan, in which they are baked before the fire, the pan resting on the ground and inclined so that the heat falls upon the top of the loaf; the handle of the pan is supported by an upright stick set in the ground. If the traveler has no frying pan the bread is baked in a "beaver tail." Such a loaf is long and narrow and is exposed to the fire upon a stick, the lower end being set in the ground; two or three cross sticks, the size of an ordinary skewer, are required to prevent the loaf from breaking and falling as it bakes. The natives in their haste usually eat these cakes before they are thoroughly cooked.

In the winter the bread is all baked before starting on the journey and is thawed when it is to be used. Fish are boiled if a second kettle is to be had; if not, they are opened along the back and roasted upon a stick set in the ground in the snow. Meat is usually boiled just enough to cook the outside. It may be roasted on a stick or suspended from a pole, cut for the purpose. Very little salt is used. Coffee is unknown. Side bacon or "cogos" is the greatest luxury in the North, though now becoming common at southern posts. Grand Rapids has imported a little butter of late years, and the Indians are very fond of it. They spread butter, bacon grease, deer's or bear's grease, all on the same piece of bread if they are so fortunate as to have them all. I regarded this appetite for grease in a 
very different light after I had lived a few months under similar conditions in the Far North.

The term "Far North" is applied to the Territory beyond the Great Slave Lake. The "Northwest" is between the Red River and the Athabasca River, beyond which lies the "North." All is included in the "Northern Department" of the Hudson's Bay Company, which has subdivided it into some half dozen fur districts. 


\section{CHAPTER III}

\section{ALBERTA}

T HAT I might descend the Mackenzie River by the first open water, it was necessary to leave Grand Rapids while the sledge travel was still good. A dog train was being sent to Selkirk, the nearest railway point, and my outfit was to be carried by it while I walked or ran with the men in charge of the team.

On the morning of February 2oth, I bade farewell to the little group of natives that had gathered to see us off. Some of them had been friendly and hospitable and I parted from them with regret. We were accompanied, for the first day, by $\mathrm{Mr}$. McLean, who camped with us at night on the portage across Long Point, near the scene of our moose hunting adventures of the autumn. During the night the dogs broke into the sled and ate all our bacon. At the time I was partially conscious that something was amiss, but was too exhausted to become fully aroused. It seemed as if an assembly of fiends was combating for the possession of our camp. Over the sleds, across our prostrate bodies, and through the smouldering fire the dogs fought, snarling and howling. The next day they were sorry looking dogs, and the one that ate the most bacon was a very sick cur. Fortunately for us there was a hunter's cabin on our route which we reached at noon. The owners of the shanty were absent upon a hunting trip in the bush, but there were several hundred pounds of fresh and dried moose meat on the scaffolds and from this we replenished our stock of provision. Small packages of tea, tobacco, etc., accompanied by a few lines in syllabic characters, written upon birch-bark or smooth pine sticks, showed that other visitors had drawn upon the meat caches for supplies. My companions examined every bundle and ransacked the premises before they could be induced to 
prepare our meal. They had to formulate satisfactory theories regarding the previous visitors before they could bring their minds to bear upon the work in hand.

With two young métis, I left our escort of three trains at the cabin, and started down the low-lying shore toward the Narrows of Lake Winnipeg. Frequent light snowfalls caused the sled to drag heavily so that we did not walk more than thirty miles each day. One evening as we were about to camp, a dark object in advance caused Donald, the man before the dogs (the hero-or victim - of the breach of promise case of the previous autumn), to halt; as we came up the boys discussed the strange appearance for some time, and finally concluded that it could not be Wenisk or Kakapasis, so it must be Pascapeet returning from Reindeer Island. The supposed dog train grew larger as we advanced and finally developed into a heap of broken ice!

The dogs were shod with canvas "shoes," which caused the driver no end of trouble and the dogs much suffering. The shoes were narrow, shapeless bags and soon filled with ice after leaving camp. They were intended to prevent the feet of the animals from being cut by the sharp, granular undercrust into which they were thrust in hauling. Judging from later experience, I greatly question whether "dog-shoes" are of any real service.

The load was lightened daily as our own provision was consumed and twenty-five or thirty pounds of fish were given to the dogs. Several pounds were also cached for the return trip. The problem of transportation of provision is as yet unsolved by the Northern voyageur. He lacks the reindeer that can forage by the way, nor has he the concentrated pemmican or blubber of the arctic explorer. Scarcely any heavier form of dog food than frozen fish can be found, and the length of sled trips are accordingly limited to ten or twelve days' duration unless game is to be had or camps found on the way.

On the fourth night we encamped on a little island far out from the western shore, with a clear horizon of snow-covered lake upon all sides, save a few islands near us. The island was encircled by drifts ten feet in depth. The temperature fell to forty-five degrees below zero, so cold was it that a birch ax handle snapped like a pipestem while cutting wood. I overheard Aleck saying to his companion during the night, "Kis- 
sinao, tapwa, kissinao,"- "It is cold, truly, it is cold." When the natives drew the blankets closer upon their shivering forms I felt that there was some cause for my own aches and sleeplessness.

On the sixth day we crossed the traverse of Fisher Bay and endeavored to reach Dog Head, a Company's post at the Narrows. We walked until nearly midnight across the trackless lake, directing our course by the moon, just visible through the haze. We were without food and had a storm arisen would have been in a dangerous predicament. We came upon a huge crack in the ice, a common occurrence in lake travel in spring, and searched some time in the darkness for a bridge across the black ribbon of thin ice. We reached the land at last, at a point only five miles from the post; not knowing where we were, we camped with only enough wood to boil a kettle of tea and with nothing to eat, though we had run sixty miles that day. My clothing was wet with perspiration and I passed a sleepless night. Soon after daybreak we reached the post and, owing to the absence of the clerk, it was some time before we could have our wants supplied. Our breakfast of tasteless boiled beef without salt and bread without butter was heartily enjoyed.

I ordered bread to be baked for the remainder of the trip and then drowsily watched the boys roll themselves in their blankets under the breakfast table. We all slept until late in the afternoon when we pushed on to Bull Head, where we passed the night in a fisherman's shanty. After six nights in the snow the chilly little garret where we slept seemed oppressively warm.

We started the next morning upon a good track, expecting to reach a cabin, thirty-seven miles distant, at the bottom of Humbug Bay, by nightfall. A strong, penetrating wind blew directly in our faces; this soon drifted the road full of soft snow into which we sank to the ankles, yet all were suffering too much from mal de racquette to wear snow-shoes. The temperature was twenty-two degrees below zero. At noon we ate our lunch at an abandoned sawmill. Toward evening we met a fisherman from Selkirk with whom my men were acquainted, and of course they were invited to have a drink of whiskey. Soon afterward a passing stranger also shared his whiskey with them, with the result that one of them came dashing past me 
stretched out on the sled with his feet dragging, alternately plying the whip and swearing at the dogs, and singing hymns in Cree. The other stumbled along for a while and then fell by the track where he lay several hours.

I had expected to ride the remaining eighty-five miles, which was over an excellent track kept open by the ox-teams of fish freighters; but my driver was too ill to walk, from the effects of the overdose of bad whiskey upon a stomach accustomed to nothing stronger than black tea, so that he occupied the sled the following day.

A few miles from Humbug Bay we reached the northern limit of the colony of Icelanders, which occupies a considerable portion of the west shore of lower Lake Winnipeg. The well-built, steep-roofed, and whitewashed log houses were in marked contrast with the low squalid cabins of the Indians. The men are employed as fishermen on the lake in summer and as lumbermen in winter. They have cleared small farms which produce vegetables and some grain. There is usually abundant pasturage for their cattle, and fish are plenty in the lake near by. "But it is not our Iceland, if we did starve there sometimes," said a silver-haired old woman who kept the "stopping-place" where we obtained lunch that day. On the following day, the tenth from Grand Rapids, as Aleck was able to run again, I occupied the cariole myself. We reached Selkirk after nightfall in the midst of a blinding snowstorm.

Taking the boys with me to the hotel, I had the pleasure of seeing them, for once, fully satisfied with food. They had run forty miles that day on a hard track, more tiring to the muscles than ordinary snow. The grinning waiter kept the supply of food replenished and a pained expression came over their faces as they realized that there really was a limit to their capacity.

Hastily boxing my outfit, which it had been necessary to carry thus far in bags, I reached Winnipeg by rail the next morning, March 2nd.

Up to this time I had not had access to any of the accounts of Franklin, Back, Richardson and others who had passed through the fur countries, and my plans were necessarily somewhat indefinite as to the point at which to leave the main route in search of musk-ox; I had concluded, after reading Pike's Narrative they could not be reached from the Great Slave Lake without great risk and hardship. 
The following letter received at this time, embodies the plans which I had submitted for approval to the University:

\section{Iowa City, IowA, March 7 th, 1893 . \\ Mr. FrankRussell, Winnipeg, Manitoba, Canada:}

DeAR SIR: In accordance with the wish of the Executive Committee of the Board of Regents of the State University of Iowa, I have prepared the following instructions for your guidance in the exploration which you have undertaken in the interest of this University.

I. We understand that the officers of the Hudson's Bay Company have endorsed as practicable the following plan, which is outlined in a letter just received from you. Leaving Winnipeg as soon as this letter and the supplies sent from here have been received, and the preparations for your trip have been completed, you are to proceed to Macleod, Alberta, and collect zoölogical and ethnological specimens until about May rst. After this you will proceed to $\mathrm{Ft}$. Chippewyan, where you will remain and collect until about June Ioth, at which time you expect to be able to proceed northward by steamer to Fort Simpson; where you are to consult Mr. Camsell, the officer in charge of that post, as to your winter quarters.

The plan, as outlined above, is approved of, and you are instructed to carry it out as nearly as possible, although you are authorized to deviate from the same in details if such deviation be, in your judgment, desirable.

2. We understand that your plan for further operations is as follows: You intend, if possible, to secure the services of a reliable Indian, with whom you will go by canoe to Fort Confidence, near the Northeast shore of Great Bear Lake, where you expect to establish a permanent camp for the winter, game and wood being reported plenty in that vicinity. When navigation opens, in the spring of 1894 , you intend to proceed by canoe to the mouth of the Coppermine River, where you will collect until approaching winter warns you to return to Fort Resolution and home.

This plan is approved, provided:

a. That it can be carried out without great personal danger to yourself. This University does not desire you to imperil your life in its service, and you are particularly instructed not to incur any dangers which would be considered as of unusual gravity by the Hudson's Bay officers with whom you consult.

b. That you can secure the services of a man known to the Hudson's Bay officers as one who can be relied upon as honest, intelligent and faithful.

3. You are expected to advance in every reasonable way the scientific objects of your expedition, which are

a. A full collection of the Mammals of the regions visited, especially the Musk-ox; Caribou, Polar Bear and Wood Buffalo, if such can be had.

b. A full collection of the Birds, especially those breeding in the far north, of which a full series of eggs, young, and specimens in summer plumage, is desired. 
๘. A collection of Insects and such Invertebrates as you can find means of procuring.

d. Notes and specimens, so far as practicable, of the Flora of the country.

e. Notes and specimens regarding the Geology and Paleontology of the regions visited.

f. Ethnological specimens illustrating the life, habits, manufactures, etc., of the natives. Notes of songs, folk-lore, traditions, religious conceptions and myths, are especially desired.

g. Meteorological observations, particularly at your winter post, for which a set of instruments has been provided by the United States Weather Bureau.

4. The Hudson's Bay Company and the Canadian Pacific Railroad Company, having granted very generous concessions for the furtherance of your expedition, this University desires that any information secured by you that may be of service to these corporations, be reported to them at your earliest convenience. You are also instructed to be guided largely in your plans by the experience and suggestions of the officers of the Hudson's Bay Company, who are familiar with the far north.

You are also expected to report as often and as fully as possible of the progress of your work in the field, and to take full notes embodying all matters of interest which come under your notice.

$$
\begin{gathered}
\text { C. C. NuTting, } \\
\text { Professor of Systemalic Zoology, } \\
\text { State University of Iowa. }
\end{gathered}
$$

I was detained at Winnipeg until March 2Ist, when I received my outfit from the custom house and started westward.

Until we had passed the shore line of the ancient Lake Agassiz the Manitoba Plains appeared under their snowy mantle as level as a lake. No signs of a thaw had as yet appeared. On the second day the country became more rolling. That afternoon we passed two recently ditched locomotives and learned that three trains were snowed in ahead of us; after a delay of thirty-six hours our journey was continued.

Between Forbes and Dunmore interesting fossils of the Cretaceous occur, but were at that season buried under the snow. Within five miles of Medicine Hat two small herds of antelope were seen near the track, though they have now been nearly exterminated, and their feeding grounds have been fenced in large ranches. Several herds of horses were pawing up the snow to reach the grass. Behind them came the cattle, which do not dig for themselves, but depend upon the horses to uncover the grass for them. 
At Calgary, I took the semi-weekly train for Macleod, a hundred miles southward. This village, twenty miles from the Porcupine Hills and fifty from the Rocky Mountains, stands upon a low rocky bluff overlooking the Old Man Creek. It is a typical frontier town, where a number of mounted police are stationed for the maintenance of law and order among the heterogeneous white population and to keep an eye on the Piegans, Bloods and Blackfeet, whose reserves are not far distant. The Piegans had tried to murder their farm instructor only a few days before I arrived, but they are usually content with cattle stealing. A policeman in a burst of confidence, informed me that the Piegans and the other "niggers" were solving the Indian problem on their own account. They were closely confined on the reserves, and were rapidly reducing their numbers by overfeeding! The site of the fort is said to have been determined by the presence of a large spring, but it is certainly not an attractive spot in March, surrounded by monotonous, undulating plains, covered with gray buffalo grass. The scanty fringe of timber along the Old Man Creek affords little shelter for birds, and the continuous chinook wind would have made collecting difficult. I therefore hastened to push on by stage to the little village of Pincher Creek, fifteen miles east of the mountains.

I learned that mountain sheep were obtainable in the range near the "Creek" and that a band of Stoney Indians from Morley were encamped in the foothills. I at once visited them and after consulting their leader, Old Peter, decided to engage him for a week's hunt. He thought a horse could be taken into the mountains by traveling on the hard crust of the snow, and we might see some sheep or goats. I accordingly hired a gray broncho, that was decidedly nervous at the sight and smell of an Indian. Peter rode an old white-eyed Cayuse and led a second, concealed under a pack consisting of a well-smoked canvas lodge and our camp outfit. Peter was dressed in an old be-ribboned blanket capote, with a ten-inch butcher knife at his belt. His feet were encased in overshoes and rags. His hat was tied on with a piece of mosquito netting which protected his ears on cold days, and his eyes from snow-blindness on warm ones.

We wound our way for two days through the foothills to the 
southward, toward Chief Mountain on the international boundary. The wind blew almost unceasingly from the westward, bringing snow squalls from the mountains. Our lodge was full of holes and the cold wind made our camps very uncomfortable. We spent several days in wading through soft, slushy snow on the hard crust of winter. In crossing deep gulches we were compelled to cut footholds with our knives as we ascended the walls of snow. Our only provision consisted of the bannocks Mrs. Peter had baked on the eve of our departure and clear side bacon; experience had taught me to furnish as little food as I could exist upon myself if I expected to have the Indian really hunt for the game.

We saw old sheep trails along the mountain sides, but neither sheep nor recent tracks. Peter concluded that after two Sundays they would come down from their winter haunts in the back ranges to graze, but that they were as yet beyond our reach. Not satisfied with the failure of this attempt, I engaged the services of a ranchman, who accompanied me thirty miles into the mountains, through the Crow Nest pass to the summit of the chain. We spent a week in that wild and rugged region, seeing only six sheep, two of which I wounded at long range but did not secure, though I followed them several hours over dangerous ground. It was the worst season possible to hunt big horn and I ought not have attempted it.

The Stoney Indians are the best men to employ as assistants in hunting in these mountains, as they are industrious hunters and experienced mountain climbers.

The last week of my stay in this locality was spent at the ranch of the Eddy Brothers. These two gentlemen hospitably invited me to "bach" with them as long as I wished and gave me every assistance in their power during my stay.

The sharp-tailed grouse and a few species of small deer were common in the bush covering the foothills, but the summer residents had not yet appeared, owing to the unusually late spring. While in the pass I secured several prime marten skins. Tracks of black and grizzly bears were seen, but these animals were not common and no specimens were secured.

The past, typified by bleaching skulls and deep-worn trails of the buffalo days, has been succeed :d by a present of barbed wire fences which, in many cases, extend for miles without in- 
terruption; the traveler is inclined to look upon these as infringements upon his rights, as contrary to the traditions of the Plains, when he is intercepted by them in traversing a direct and well-worn trail, and compelled to follow new and as yet little-used roads platted on the lines and angles of surveyed sections.

I reached Edmonton on the 20th of April. This frontier town is the present terminus of the northern branch of the Canadian Pacific Railway; it is situated on the north bank of the North Saskatchewan, nearly two hundred miles north of Calgary on the main line of the railroad. As at Macleod, the traveler is landed on the opposite side of the river, three miles from the town. The ice was just breaking up in the river and a thrifty Scotchman was ferrying passengers across an open channel in the middle, ten yards wide, at twenty-five cents each.

This was the last point at which I could purchase provisions for the far north, where I expected to depend on net and gun or on the Company's posts, supplied principally with the meat and fish of the country. I did not wish to hamper myself with a large outfit, nor did I have the means with which to pay the charges for transportation. The list of supplies, a considerable portion of which was given in gratuities to the Indians, was as follows:

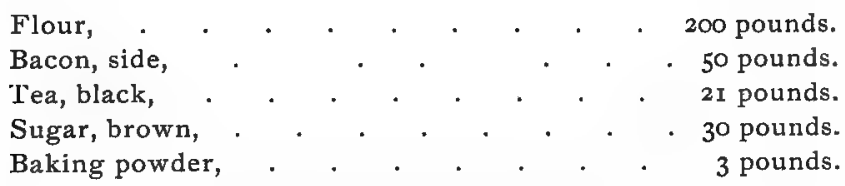

The outfit, including provision, fixed ammunition, two 45-90 Winchester rifles, and a ten-and a twelve-bore shotgun, weig hed but 750 pounds.

The presence of rival traders at Chippewyan compels the Company to send a spring outfit to that post by boat as soon as navigation opens, usually about the first of May. As I wished to reach Lake Athabasca in time to collect a series of the first migratory birds, I made arrangements to accompany this early boat instead of waiting for the steamer "Athabasca," which starts down the Athabasca River a month later. All of the freight to and from the north is hauled by wagon from Edmonton to Athabasca Landing, a distance of ninety-four miles, whence the water route extends to the Arctic Sea. 
The party leaving Edmonton on the 26th of April, I893, consisted of Captain "Joe" Faville, an old English métis, master of the "Grahame," then lying at Chippewyan; Captain J. W. Mills, going in to take charge of the "Wrigley," the writer and four engaged servants of the Company. To "go in," by the way, is to descend the Athabasca; to return to civilization is to "go outside." We passed the last farm houses on the first day. The snow still lay in the poplar thickets. The nights were cold, the road rough and muddy, and the dreary monotony of the scrubby bush was yet unrelieved by the awakening of spring.

The officer at Edmonton had supplied us with "everything that we required" until we should reach the landing. Upon opening our stores we found tea, bacon, and a short allowance of bread. This thoughtful genius had concluded that we should begin our training for the straight meat and tea of the North by foregoing butter, sugar, etc., while we still had such luxuries as bacon and bread. As we discussed at mealtime the consideration of our commissariat, Captain Mills voiced the sentiments of the party in select colloquialisms, taken from the several languages with which he was acquainted and which he could combine most artistically, even for a steamboat captain.

On the third day we followed the course of the Towwatinnow Creek beyond the divide between the waters flowing to the Arctic Ocean and to Hudson's Bay. The appearance of the country had changed; the sandy hills were scantily clothed with "jack pines," and the spruce became more abundant on the lower grounds. A few Indian lodges were seen at a distance with a herd of ponies near them.

We overtook several métis freighters, whose lank and bony cayuses crept along at a pace that must have taken a week to reach the landing. They slept at night under their wagons, while their horses grazed upon the dried grass of the preceding season-their only food. Upon reaching the crest of the hill overlooking the picturesque valley of the Athabasca, at its northward bend, we were greatly disappointed to behold the river still locked in the ice of winter. We were compelled to wait four days before it opened and we could safely follow the retreating floes. The lakes about the country were still frozen so that there was no shooting to be had, though the waterfowl were passing daily. 
A quarter of a mile up the river was the free traders'1 establishment, where a barge was being built to take down their summer outfit. Below the Company's wharf lay the "Athabasca,"a stern-wheel steamer, drawn out upon the bank for the winter. Beyond, was a depot containing goods for the Roman Catholic missions of the North, and near by two young Scotchmen had pitched their tent to await the first trip of the steamer toward the Peace River valley where they expected to engage in farming. A small squad of mounted police was stationed at the landing to prevent liquor from being carried into the North. On the night of May $2 \mathrm{~d}$ we were awakened by the uproar occasioned by a passing skiff, containing a large quantity of whiskey, which, owing to the darkness and the dangerous condition of the river, succeeded in escaping.

The long journey was begun on the following morning, when we embarked in a York boat that had evidently passed through some hard service. Our craft was twenty-six feet in length, and loaded with three tons of miscellaneous merchandise, including six hundred pounds of newspapers for the fur posts and the missions, which had accumulated at Edmonton during the winter. Our crew consisted of the jolly cook of the "Grahame," two Red River métis and two Crees from Lac la Biche. Owing to severe illness, Capt. Faville remained at the landing, and Captain Segur, of the steamer "Athabasca," accompanied us to take charge of the "Grahame."

The river banks were lined with ice, in places forming continuous overhanging walls, making it difficult to effect a landing. At mealtime, after boiling the kettle, we would push off and drift while eating. Aided by the swift current, on the third day we reached the Grand Rapids of the Athabasca, one hundred and sixty-five miles below Athabasca Landing.

As we were approaching the rapids, the roar of which could be plainly heard, the cry of "mooswa" was raised. Two moose were walking along the edge of the ice wall, eight feet above the water. They were evidently searching for a place of easy descent to enter the river and swim across. The two captains opened fire when within a hundred yards. One of them declared afterward that "the boat was too unsteady to shoot from;" the

1 The term "free trader" is not used in its old world sense of smuggler, but is applied to anyone trading in opposition to the Company. 
other denied having buck fever but acknowledged being a little "nervous." At all events, when the smoke cleared away, the moose were still uninjured. We were swept some distance down stream before we could make fast to the broken and dangerous ice. Running back along shore, we cautiously approached the spot where the moose were last seen, but they had disappeared. We were about to turn back, thinking they had entered the woods, when the ears of one of the animals were seen above a hummock in the midst of the tumbled mass of ice blocks, slush and mud. The ice had given way beneath them and both moose were floundering in pits too deep to admit of escape. We were without fresh meat and quite willing to kill one, but it was only after every effort to rescue the other had failed that it, too, was slaughtered. Unfortunately, the skins were worthless as specimens at that season. After an hour's hard work, the bodies were dragged out and rolled into the river to be picked up by the boat below.

We encamped a short distance from the rapids upon a steep hillside and passed an uncomfortable night on sloping ground, with everything soaked by the water trickling from the banks of melting snow above us. The boys feasted until a late hour upon choice morsels of moose meat. "Lixie," one of the Crees, declared it to be "bacon breakfast;" these were the only English words that I ever heard him use. They probably seemed to him to express the highest praise.

We ate our breakfast in the morning before embarking-no floating there-and pulled across to the eastern bank to inspect the channel, which it was feared would be obstructed with ice. The portage is made across an island, four or five hundred yards in length, lying in the middle of the stream. The steamboat landing is a mile above on the right bank, whence the goods are taken in boats through a crooked channel blasted through the huge nodular sandstone boulders to the head of the island. A dilapidated wooden tramway extends across the island, at the foot of which the rapids are still so strong that the sturgeon-head boats of the "Athabasca Transport" have to be dragged through with a line. The free traders carry their goods along the east bank and lower their boats with a line through the rapids, a descent of sixty feet.

Pushing off again, we were soon in the grasp of the swiftly 
increasing current. As we entered the channel leading to the island, the roar of the rapids drowned the voice of the bowsman, who indicated the channel to the steersman by signals, but losing his head at a critical moment, he raised the wrong hand, resulting in the boat being swept against a rock with a swing and lurch that nearly capsized us. The crash of timbers and the yells of the frightened Indians mingled with the roar of the rapids, over which it would have been certain death to have gone. Happily for us, the boat was swept clear and reached the landing place safely. We were a day and a half in portaging our boat and cargo. I occupied a part of this time in collecting fossils. The river here cuts through a Cretaceous sandstone, containing such a large number of nodular concretions that they pave the bed of the stream as the softer matrix is worn away. These boulders are from six inches to fifteen feet in diameter, and most of them are as smooth and spherical as if they had been turned in a lathe. In pouring over such a bed at a steep pitch, the whirling, foam-crested waters are tossed and dashed in such wild confusion that no boat could live there for a moment.

Near the head of the island stands a small storehouse, near which a large quantity of flour was piled in sacks. It had lain there since the preceding summer, with no other protection than the double sacks in which all flour for the North is placed. The first rain had formed a hard crust on the exposed parts and this afterwards protected the interior.

Upon this island, on the 6th of May, we encountered the first mosquitoes of the season, and were to know no peace by day or by night, in house, or tent, or boat, owing to their persistent, malevolent, fiendish persecution, until the snows of autumn should banish them for another eight months; for there are but two seasons in the Land of Desolation-a snow season and a mosquito season.

Capt. Segur had placed an Indian, familiar with the rapids, at the steering oar, to guide us through the rough water below the island. As a result of a prolonged debauch upon smuggled whiskey, he was too weak to manage the heavy sweep, and we were carried through, side on, not only shipping water, but in imminent danger of the old boat going to pieces in the breakers. The river has a total descent of three hun- 
dred and sixty feet in the next eighty-five miles and is interrupted by ten rapids. The valley narrows to a cañon, three to five hundred feet in depth, having a series of terraces throughout most of its course.

Seventeen miles below the Grand Rapids, we came upon a gas well, marked by a line of bubbles that extended halfway across the stream. On the following day we reached the Cascade Rapids, where a series of rock ledges creates an overfall in midstream with swift and shallow rapids on either side. Ordinarily a portion of the load is portaged along the left bank, with the flat rock of the river bed for a portage road, but at the time of our arrival, this was covered with broken and overhanging ice, piled to a height of twenty feet. Packing goods across portages is no uncommon experience for the Company's servants in the North, yet our crew flatly refused to "carry" over such a path, as it would be necessary to make for at least a quarter of a mile, along the steep slope of tar sands and mud slides. Thinking better of it next morning, however, they set to work carrying with tomp lines, improvised from canvas folded so that it could be placed next the forehead and ropes at the ends to attach to the bales. Partly from a desire to be "doing," and partly from a curiosity as to how it felt to "pack," I shouldered a hundred-pound sack of BB shot and started with the others. The load did not seem heavy at first, and save a little unsteadiness in the knees in climbing the steep inclines, I experienced no difficulty. I was regretting that I had not taken two pieces, as do the voyageurs at each trip, when we came to rougher ground and that lead began to increase rapidly in weight. Just as I was about to throw it down, I reached a convenient ledge on which to rest and after a short "spell" finished the portage. My curiosity was satisfied, but I carried over a second piece, a bale of dry goods, and found it much easier to carry than the springless, dead weight of the shot. With a half load we attempted to run the short rapid. The boat struck on the last ledge and all hands had to tumble out and carry several hundred pounds ashore through the chilling cold water, in which large pieces of drift ice were running. We were under the overhanging wall of shore ice, several tons falling with a crash within two minutes after we got clear of it. We soon encountered other rapids below, in 
the passage of which we were dashed with spray and our boat, weakened with age, threatened with destruction. It was an exciting experience-to be drawn into the boiling flood; the bowsman, crouching low to avoid being hurled from the tossing boat, signalled to the steersman who guided us with powerful strokes of the great sweep and directed the crew with the command "pimiscow"-pull, or "see"-back-water. When running the Boiler Rapids, one of our Crees, instead of attending to his oar and assisting in bringing the boat around the sunken boulder in the middle of the channel, turned to stare at the rapids, his oar caught against the rocks and the inner end struck him amidships, hurling him against the man next in front. Had the thole pin not given way he would have been pitched into the midst of the rapids. Such accidents are not uncommon; if short of actual tragedy, the victim must bear the ridicule of the whole boat's crew for the remainder of the voyage.

On the eighth day we reached McMurray, an insignificant post at the mouth of the Clearwater River. Goods arriving in boats from the Grand Rapids of the Athabasca are there transferred to the steamer "Grahame," that being the southern limit of her run. The Clearwater, also containing many rapids, was the route followed to and from the North previous to the building of the railway across the plains. Down this stream Peter Pond made his way from the Long Portage, one hundred and fifteen years ago. Mackenzie, Franklin and other distinguished explorers have traversed and described the valley of the Clearwater and the direct route thence to the Arctic Sea. Below the "Forks" the bluffs recede from the river and decrease in elevation. The Athabasca attains a width of nearly half a mile and contains many islands of silt and driftwood, covered with a dense growth of spruce. We drifted at night on the lower river and made such rapid progress that we reached Lake Athabasca on the tenth day. We were still twelve miles from Chippewyan, but could not sail directly to it owing to the ice not having broken up. We had been told that Captain Segur was a "good judge of water," and expected he would guide us through the shallow channels among the bars and islands along shore. Leaving the main stream we entered a channel which the Captain declared to be the Embarras 
River. ${ }^{1}$ This grew narrower as we advanced until, after an hour's rowing against a strong wind, it ended abruptly in a clump of willows. The worthy Captain was conceded to be "a good judge of water but a mighty poor judge of land." We reached the main stream again just as darkness was setting in. There was no dry ground on which to camp, or even to build a fire. From our position nothing could be seen but an apparently endless stretch of driftlogs with their spreading roots anchored on the battures, except toward the southwest, where miles of willows fringed the water courses. It had rained all the afternoon, and the absence of a fire to dry our clothing was severely felt. A small fire, large enough to boil a kettle of tea, was made among the roots of the stranded stump to which we had made fast for the night. Dropping down the river in the morning we soon reached a channel with a strong current, entering from the west, which proved to be the Embarras. Ascending this for three or four miles we turned into a branch flowing toward Chippewyan. We were compelled to wait two days at its mouth until guides were sent to conduct us through the ice-obstructed channels among the islands before the post.

As we were passing the broad mouth of the Peace, several members of the party discovered "a big moose walking on the batture and coming this way." Rifles were hastily taken from their cases and everyone dropped behind the gunwale of the boat. Two métis in our party were about to wade toward it when the supposed moose resolved itself into the uplifted roots of a huge cottonwood driftlog!

Our journey of five hundred and thirty miles had occupied twenty days, including the delays at Athabasca Landing, the Grand Rapids and the Cascade. Just before our arrival the snow had been cleared off by a heavy rain, though many drifts still remained on the northern slopes.

1The channel known as the Embarras River obtained its name from the driftwood with which it is said to have been obstructed. "The 'Embarras' in no place exceeds one hundred yards in breadth, and the slack current makes it preferable as a route [in ascending the stream] to the main river, where the current is very strong. Its banks in places are steep, and like the Slave River, thickly clothed with willow and poplar, some of the latter very large. The waters are abominably dirty." Pullen, British Arctic Blue $B o o k, 1852$, Vol. 5o, p. 62 . 


\section{CHAPTER IV}

\section{ATHABASCA DISTRICT}

CHIPPEWYAN ${ }^{1}$ is situated at the extremity of a peninsula, of irregular outlines, which is connected with the north shore by a low, narrow neck. The red gneissic rock is frequently exposed, and at intervals, as between the promontory occupied by the Company's buildings and that on which the mission stands, has been ground into sand of a characteristic color which forms a pretty beach. The hollows between the broken hills support a muskeg growth of moss and tamarack, while the scanty soil of the slopes affords a foothold for small spruce and birch trees.

Chippewyan is the leading post of Athabasca District and is one of the most extensive establishments in the North, being second only to Simpson, the chief station in Mackenzie District. The buildings are of hewed logs and whip-sawed lumber. The "Grahame," a fair-sized stern-wheel steamer (and during the winter of $1895^{-6}$ a second vessel, to replace the first) was built there, also with hand-sawed lumber.

Upon the rocks just east of the quadrangle of whitewashed Company's buildings stands a small tower, which was built nearly a century ago in order to watch the movements of the Indians, who it was feared, were planning to massacre the whites. One of their medicine men had prophesied that peace and plenty were in store for them if the whites were exterminated, and that other traders would soon come in, bringing more and better goods. Until the amalgamation of the fur com-

1 Lake Athabasca and Chippewyan, are both known as Athabasca. The settlement is called "Rabaska" by the métis. "Les sauvages l'appelaient ayabaska à cause des grandes herbes qui en couvraient les bords, et les 'voyageurs' en ont fait' ' Rabaska' "!-Masson, L. R., Les Bourgeois, Vol. I, p. 36. 
panies in $182 \mathrm{I}$, the Hudson's Bay Company occupied Coal Island calling their station Fort Wedderburne. ${ }^{1}$ Then, as now, the rivalry between the traders induced them to visit the Indian camps to procure furs and meat. During the winter preceding my visit each establishment kept men and dog teams ready to start at a moment's notice, whenever the hunters sent in a report that they had some "fur." If an Indian secured a few marten skins, worth ten or fifteen dollars, a boy would be sent in with an empty sled to report the fact to one of the traders, who would at once send his interpreter for them. The other would soon hear of it and dispatch a courier in hot pursuit. When the messenger arrived at the camp, the Indians had to be given a little tobacco, flour, tea and sugar before furs were mentioned. Then the whole story would be repeated-how the Company had always looked after its red children and fed them when the fishery failed, how they had brought them goods when others could not, and goods of a quality far superior to those of the opposition, which was not going to be in the country another year anyway; if they deserted the Company now, they would be left then to shift for themselves. Or, if it happened to be the free trader's interpreter who was speaking, he would tell the Indians of the many years during which they and their fathers had been defrauded by the Company, which never paid well for furs until his employers came, that now they brought the best of goods to give their red brothers, at ridiculously low prices, all of which would finally result in a bargain, wherein the furs were bought at the Edmonton price. If a hunter is fortunate enough to secure one of the dozen silver foxes which are trapped each winter, he is feasted and fawned upon until he thinks he is conferring the greatest favor in part-

"1The post was first established by Roderic Mackenzie, on the south shore of the lake, just east of the debouchure of the Athabasca, pitched upon a conspicuous projection which advanced about a league into the lake, the base of which appeared in the shape of a person sitting with arms extended the palms forming, as it were, a point. On this we settled and built a Fort which we called Chipewean. It is altogether a beautiful, healthy situation, in the centre of many excellent and never failing fisheries, provided they are duly attended to at the proper season. Considération importante dans ces tristes régions ou le poisson était à peu près la seule ressource des Bourgeois et de leurs employés pendant les longs mois d'hiver." Masson, L. R., Les Bourgeois, Vol. I, p. 37. 
ing with it for two hundred "skins"1 (one hundred dollars) and a gratuity of a hundred pounds of flour and a long list of other articles of trade. The Indians have learned that they can get more flour at Edmonton for their furs than at Chippewyan, and every year or two a party of them, led by some freeman (discharged Company's servant), visits the outside world. Their time is worth nothing, and they cannot understand why they should pay more for heavy merchandise at Chippewyan than at the railway terminus.

Lake Athabasca is the northern limit of the territory of the Crees; beyond, the various sub-tribes of the Athabascan stock occupy the country as far as the narrow strip along the coast, which is inhabited by the Eskimos.

The Chippewyans trading at the fort are more numerous than the Crees and, if possible, more filthy and destitute. The productive fisheries about the lake and the abundance of hares insure them against starvation, while clothing may be easily obtained by a few weeks' work in the fur season.

A great deal of their time is spent in gambling, at which they will occupy themselves for days together and wager their last ounce of ammunition upon which they are dependent for food for the morrow.

Delta. The Athabasca and Peace Rivers are both fed by the melting of mountain snow and both carry an immense quantity of mud and driftwood into their deltas, which have been extended several miles from the hills that mark the original boundaries of the lake. The two streams now have a common delta lying in a semicircle, five miles southwest of the fort. This accumulation of silt has cut off a portion of the lake over twentyfive miles in length, called Lake Claire. The swamps and mud flats of the delta are intersected by a network of channels through which the water flows in either direction, according to.

${ }^{1}$ The skin is the standard of values in the North. Formerly it meant a beaver skin, but it has come to have a fixed value equivalent to about fifty cents in Canadian money. It appears on the Company's books as "Made Beaver," abbreviated to MB. All trade north of Athabasca Landing is carried on by barter, there being no medium of exchange of any sort. The best "money" that a traveler can carry into that region, if he wishes to deal directly with the Indians, is tea and tobacco; the former, black and of good quality, the latter in the form of slender twisted plugs know as "negro-head." 
the stage of water in the rivers, or the tides of the lake as influenced by the wind. These channels swarm with muskrats, and in the migratory season myriads of waterfowl halt upon the battures to feed, while a comparatively small number remain during the summer to breed in the adjoining marshes. More geese and ducks are killed there than at all other posts in the North. The big and little waveys are the most abundant and the most highly prized, though swans and Canada geese, ducks and cranes abound.

It would be several weeks before I could continue upon the journey northward, and as I could not live at the post and collect in the delta, I secured a skiff the day after our arrival and, provided with a few pounds of flour and bacon, set off alone toward the southernmost of the rocky islands in the delta of the Quatres Fourches or Peace River, which has deposited its silt between them until they are connected by low grass-covered swamps containing many shallow lakes. The channels are all willow-fringed, no other tree or shrub growing upon the low grounds. The only tent I could get was five feet in height, without walls-a very poor shelter in which to live and work for five weeks. For three days after reaching the island it snowed almost continuously, making collecting rather disagreeable work, especially as I had no means of warming the tent and had neither seal nor rubber boots.

The catkins of the earliest willows burst their envelopes on the $24^{\text {th }}$ of May, the first warblers arrived on the same day. Thenceforward leaf and blossom rapidly developed though snow fell as late as June I4th. Frequent rains and northerly gales rendered camp life anything but pleasant.

Each morning was spent in making a four or five mile trip with the skiff among the islands, in search of water birds. As I depended on the game secured for food, the success of the morning's hunt had a material effect upon the bill of fare for the day. The afternoons were spent in skinning birds, a task which, from the loneliness, became inexpressibly monotonous. After supper, consisting of hot tea and fried duck, if it was not raining, or of cold meat and cold water if it were, I would spend an hour or two in collecting land birds, to be cared for next day. A family of whiskey jacks was disposed to dispute my right to encamp near them; they would sit and scold for hours 
until driven away. Two young ones, in an interesting phase of immature plumage, were specimens too desirable to be disregarded. For two weeks after they had been killed the mother hovered about with a pathetic call similar to the mewing note of the catbird.

It required constant care to prevent the mice from destroying the birdskins, notwithstanding the fact that they were thoroughly covered with arsenic. This was the only time that I ever felt any injurious effects from constantly handling the poison. After five weeks of introspection, arsenic and rain, I was glad to enter upon the next stage of the journey, though I had been very successful in securing a representative series of Quatres Fourches birds.

Early on the morning of June 2oth the "Grahame" started on her first downward trip. We soon entered the Rocky River, which becomes the Slave after its junction with the Peace, thirty miles below. The northern limit of navigation for this steamer is Smith Landing, at the head of the Smith Rapids, a hundred miles from Chippewyan. A submerged snag was struck as the boat approached the landing place, causing a hasty scramble on the part of the Indians, who tumbled several tons of freight ashore, and some of it into the river, in their haste to bring the leak above the water line. Aided by Captain Mills, I succeeded in having my outfit safely landed. From Smith Landing to Fort Smith, a distance of sixteen miles, the river is interrupted by a series of rapids with a total descent of two hundred and forty feet. These were formerly passed by six or seven portages; the goods and furs were carried and the boats dragged across on rollers cut from drift logs. The free traders still follow this old boat route. But the Company has fransported all its freight for the last few years in ox-carts over a swampy trail around the rapids.

On the 2Ist I accepted Dr. Mackay's invitation to descend the rapids in his canoe. We crossed at once from the Big Eddy at the Landing and dropped down along the right bank for nearly a mile before reaching the first rapid. We then followed narrow channels at some distance from the main river. After running through a few small rapids we reached the Chest Portage. While the men were carrying the canoe across, I visited the falls below the landing place. The channel was about forty 
yards in width, with perpendicular granite walls. A huge quadrangular boulder had fallen from the left bank, obstructing the stream so that a high cascade was formed; below, the steep descent of a hundred yards terminated in an overfall into a circular basin two hundred yards in diameter, into which fell several other cascades. The outlet to this boiling cauldron was by another fall of considerable height.

Tormented by clouds of mosquitoes, we continued our journey past small rapids and numerous islands until we reached a large eddy wherein hundreds of driftlogs were circling, the channel below being entirely concealed by a log jam that was probably centuries old.

Two short portages were formerly made here along the east bank, but the New Portage, on the other bank, is much longer. This rapid is larger and still more picturesque than the Cascade above. Great heaps of driftwood lay upon the rocks and the heads of the islands; the logs, denuded of their bark and frayed and worn by long buffeting by the stream, mingled their whitened forms in inextricable confusion. The muddy waters poured through the granite gorges to fall with ceaseless roar in cascades of considerable height. The heavy forest, through which the sunlight scarcely penetrated, stretched in an unbroken wall on either bank. The wild grandeur of the scene was unmarred by evidences of man's presence, save the grassgrown portage path and a few crumbling posts beside the Raft Portage, which marked the grave of a Good Hope Indian. As we sped swiftly down the narrow channel below, we saw frequent signs of the presence of beavers; Mackenzie reports their occurrence there in great numbers at the time of his journey in I789. The métis kept a constant lookout for bears, which were said to be common in the vicinity of the rapids.

Emerging at length from the labyrinth of islands we crossed the main stream, here over a mile in width. Some of the islands were covered by several feet of silt, deposited by melting ice; this was honeycombed by bank swallows. Other islands of naked rock afforded a secure nesting place for gulls. A short distance above us the mist hung over the rapids, where the main stream poured over the ledges that had interrupted our course at the New Portage.

Before us was the "Mountain," a narrow ridge extending 
from the left bank for nearly a mile and terminating in a series of ledges over which the narrowed stream poured in a tumultuous, roaring torrent. A wooded island in midstream is occupied as a breeding place by hundreds of white pelicans. When we landed upon it there were scores of them about the nests, covering the ground. They had destroyed all undergrowth, but the heavy spruce overhead prevented their rising in flight until they waddled to the bank. Eggs in various stages of incubation were scattered about, and many naked nestlings huddled together in squeaking heaps at our approach.

The Mountain Portage is a short ${ }^{1}$ one across the high, steep, sandy ridge. It is so narrow that a cut across the top several feet in depth has been made; boats are dragged across with the aid of block and tackle. The portage was at one time made along the right bank, but was abandoned as being too dangerous. After passing some very rough water at the foot of the rapids we crossed to the east bank of the river, flowing in a straight reach to the Portage of the Drowned (Portage des Noyés ${ }^{2}$, over which boats are run with a half load.

The fishery at the foot of these rapids, the last obstruction of any consequence in the Mackenzie River system, has induced several Indian families to build cabins along the right bank. We carried our canoe along the portage path before their doors, and reëmbarked to cross the broad stream to Fort Smith. This fort stands on the level, sandy plateau, high above the river. At the time of my visit, the Company's buildings consisted of three low, barn-roofed log structures, without the neat whitewashed fence to be seen at other northern posts. The indispensable flagstaff stood at the edge of the bluff. A log warehouse beside the steamboat landing, the mission, and a few scattered huts made up the "Fort," named in honor of the present governor of the Hudson's Bay Company, though it has been termed 3 "the most disreputable establishment" and "the

1 "Seven hundred paces." Richardson, Arctic Searching Expedition, p. 91. It was known to the early voyageurs as the Pelican Portage, the name "Mountain" being at that time applied to a smaller portage above. Mackenzie mentions "the hill," which was crossed by a portage of 820 paces. Voyages, p. 5 .

2ur In the year 1786 , five men were drowned, and two canoes and some packages lost, in the rapids on the other side of the river, which occasioned this place to be called the Portage des Noyés." Mackenzie," Voyages, p. 5.

'Pike, Warburton, Barren Ground, p. I7. 
worst place for mosquitoes in the North." The mosquitoes and bulldog flies ${ }^{1}$ swarmed about the oxen used on the portage, driving them frantic when on the road, and causing them to spend most of the night in the smoke of fires kindled to protect them. At each house a pan of wet chips was kept burning before the door, producing an odor not exactly that of incense. Under favorable atmospheric conditions they would gather in such numbers as to cover the greater part of one's clothing, each individual searching with feverish activity for a vulnerable spot. Les maringouins settle upon you like angry bees and no amount of switching or brushing will drive them off.

When I attempted to collect birds the mosquitoes sometimes actually covered the gun barrels and concealed the sights. The mosquito helmet I was compelled to wear seriously obstructed my vision, and they always found their way through its meshes. They have not the timid and hesitating manner that characterizes the southern mosquito, but realizing that their summer is short and naturalists are few, they waste no time but light squarely upon their bills and go to work. I have smeared coal oil, bacon grease, and other precious ointments upon my

1 "June 23d, [1848]. The Tabanus named by the voyageurs 'Bull-dog,' has been common for two days. The current notion is, that this fly cuts a piece of flesh from his victim, and at first sight there seems to be truth in the opinion. The fly alights on the hands or face so gently that if not seen he is scarcely felt until he makes his wound, which produces a stinging as if the skin had been touched by a live coal. The hand is quickly raised toward the spot and the insect flies off. A drop of blood, oozing from the puncture, gives it the appearance of a gaping wound, and the fly is supposed to have carried off a morsel of flesh. In fact, the Tabanus, inserts a five-bladed lancet, makes a perforation like a leech-bite, and, introducing his flexible proboscis, proceeds to suck the blood. * * These Tabani are troublesome only toward noon and in a bright sun, when the heat beats down the mosquitoes." Richardson, Arctic Searching Expedition, p. 67.

This fly is larger than the familiar blue-bottle. I frequently noticed that they seemed to pursue a premeditated plan to make their way to my hands or face, unobserved, by alighting on my cuffs or collar and crawling thence to the exposed flesh. I first met them at Selkirk, on the Red River where they are a great pest. At Chemawawin, on the Saskatchewan, our tent, one sultry afternoon, was filled with them as by a swarm of bees. We surrendered our domicile to them and went outside among the mosquitoes which, at least, sounded a warning before making an attack. The bull-dog is found, I believe, throughout the entire Northwest. Schwatka (Along Alaska's Great River, p. 125) mentions the occurrence of a "horse" fly on the Yukon, which is probably a species of Tabanus. 
face and hands, with only a temporary effect. My face and wrists were often swollen from their poisonous attacks. ${ }^{1}$ Sleep is impossible without a net to completely cover one. Indians, who have no nets, lie half suffocated with their heads covered by their woolen blankets. I was once forced to follow this plan in the mountains of British Columbia, and nothing but extreme exhaustion could have induced sleep.

The clerk in charge at Fort Smith was living upon dried suckers. These fish are obtained in large numbers below the rapids, and form a considerable part of the food supply of the Indians of the neighborhood. While they are drying, a little sand finds its way into the gashes made in the fish, where it remains to grate upon the teeth of the unfortunate compelled to eat it.

Captain Mills and I set out on June 26th to visit the Salt Plains, from which the salt for the North is obtained. The salt springs are situated forty miles northwest of Fort Smith, and are reached by descending the Slave to the mouth of the Salt River, a distance of fifteen miles, and ascending the latter stream. On the way we landed at Bell's Rock, six miles below the post, and made an unsuccessful search for fossils. This low ledge of brecciated limestone and that underlying the Pointe de Gravois on the right bank, two miles below, are the only exposures of limestone that I saw on the Slave River.

The swift current at Gravel Point forms a strong eddy where fish are always abundant. This unfailing food supply accounts for the presence of three or four Indian cabins on the bank above. Permanent habitations at any distance from the Company's posts are of rare occurrence. The presence of a fishery at the mouth of Salt River was indicated by the large number of drying stages. The ruins of a $\log$ cabin were visible from

1Compare King, Narrative, p.4I. "In addition to the scorching heat of the sun, we had been tormented by the mosquitoes, and so disfigured by them that it was difficult to distinguish one man from another." Commander Pullen wrote of the experiences of his boat party with mosquitoes, in descending the Mackenzie, "Day or night made no difference to them; they were our eternal tormenters, and in no hot country that I have ever been have I found them so troublesome. In the daytime they were not our only pests, for the bulldogs (immense large flies) were almost as thick and troublesome with their sharp and poignant bite; so between them both we got but little rest." Fournal (Br. Blue Book), 1852, Vol. 50, p. 34 . 
the main stream. This was built by Beaulieu, who was guide and hunter of Franklin's second expedition.

Salt River is from thirty to sixty yards in width, and for ten miles above its mouth is without perceptible current. Beyond that point the water is distinctly brackish. The stream winds in horseshoe curves through a broad valley, timbered with spruce and aspen. I collected a pair of half-grown horned owls, a raven and several ducks, while ascending the river. The Salt Plains are five miles in width and lie at the base of hills rising to a considerable height. The springs were first described by Richardson, who visited them in 1820 . They are near the base of a hill ${ }^{1}$ and are enclosed by basins, from which the water evaporates and leaves large quantities of pure crystal salt. The clerk at Fort Smith annually sends a boat to the springs for a load of salt, which is stored in bags at the mouth of the river and taken on board the steamer for distribution throughout Mackenzie River District.

When in sight of this "mountain" we were compelled to turn back, as the captain expected the "Wrigley" to arrive at Fort Smith that evening. We reached the post on the evening of the 28 th, but the "Wrigley" did not arrive until the morning of July 2 d. Several officials of the Company, missionaries, retiring servants en route to Winnipeg, and fourteen Hare Indians from Good Hope, who were to work on the Athabasca River transport, were on board.

We started down the river at three o'clock A. M., July $5^{\text {th. The }}$ "Wrigley" had two pilots, called "guides" since the York boat days, when the leader of the brigade really served in that capacity. One of these, "Old" John Hope, was a pure blood Cree; the other, José Souiar, known as "Susy," was a French métis. Owing to the high latitude, the "Wrigley" has continuous light on her thirteen hundred mile run until late in the season, so that one of these men was always at the wheel when the boat was under way.

The Slave River is about half a mile in width below the rapids, except where it expands to include the somewhat numerous wooded islands which resemble those in the lower Athabasca.

During the day we rounded Le Grand Détour, traveling fifteen miles to gain a few hundred yards, and at Point Ennuyeux

${ }^{1}$ See illustration in Back, Narrative, p. 8 . 
we were an hour in going around a bend that is crossed in winter in five minutes. Near the mouth of the river we stopped to wood up, at midnight, soon after which the steamer ran at full speed upon a gravel bar. The boat heeled over until I was nearly thrown out of my bunk. "Susy," who was at the wheel at the time, remarked in a satisfied tone, "I thought me there was a bar here somewhere."

We were four hours in getting off. We then entered one of the western channels of the broad delta and passed three or four miles of mud-flats off the mouth before reaching the deep water of the lake. Turning southward around Mission Island, we reached Resolution early on the morning of the 6th. The anchor was dropped two hundred yards from the beach and a few pieces were sent ashore.

An unusually large number of musk-ox skins had been brought in, and rivalry between the Company and the free traders had trebled the price formerly paid for them. This had emptied the store and caused goods to be supplied at the first, instead of the third, trip of the steamer.

I counted sixty lodges on the beach before the fort. The most of them were occupied by Yellow Knife Indians from the north shore of the lake.

At nine o'clock we were under way again, headed for Rae on the Northern Arm. The main body of the lake is sixty miles in width and the Northern Arm is eighty in length. This broad traverse requires a much more seaworthy vessel than are the upper river steamers. The "Wrigley" was built at Fort Smith in I886, all the lumber used being sawed by hand. Her dimensions were eighty feet keel, fourteen feet beam, six feet draft, with a four and a half feet screw. Her average speed on the lake is over eight miles an hour. The running time from Fort Smith to the northernmost post (a distance of over twelve hundred miles) is five days. The return trip against the current of the Mackenzie requires eight and a half days. She is soon to be replaced by a new boat, to be built during the winter of $1896-7$. 


\section{CHAPTER V}

\section{FORT RAE}

W $\begin{aligned} & \text { HILE crossing the lake, I had an opportunity to discuss } \\ & \text { my plans with } \mathrm{Mr} \text {. J. S. Camsell, who was accompanying }\end{aligned}$ the "Wrigley" on her first trip. He considered the plan of wintering on the Great Bear Lake impracticable, owing to the difficulty of securing the assistance of the Indians, and strongly advised me to make Rae my headquarters, as a larger number of musk-ox robes were traded there than at any other post except Resolution. He thought that an interpreter could not be easily found about the Great Bear Lake who would be willing to enter the Barren Ground with me. Both he and Captain Bell recommended a young Indian, the adopted son of the French métis assistant clerk at Rae, who they thought would be willing to act as interpreter and man-of-all-work, if I decided to winter on the Great Slave Lake.

Seven miles from Rae, we entered a narrow buoyed channel only eight or ten feet in depth. La Grosse Ile, a granite island a hundred feet or more in height, extended for some distance on our left, on the right a large number of barren rocks and wooded islets fringed the shore of the mainland. As usual on the arrival of the steamer, the British flag, with the talismanic white letters $\mathrm{HBC}$, was flying at the post. We anchored some distance from the beach, and the officer in charge of the post came on board. He was accompanied by the boy, Andrew Leviolette, whom I wished to engage. Andrew made no objection to the terms offered by $\mathrm{Mr}$. Camsell, and readily agreed to work for a skin a day and his board.

At I A. M., July 7th, the "Wrigley" weighed anchor and started on the longest voyage of her season's run. Rae is not on the 



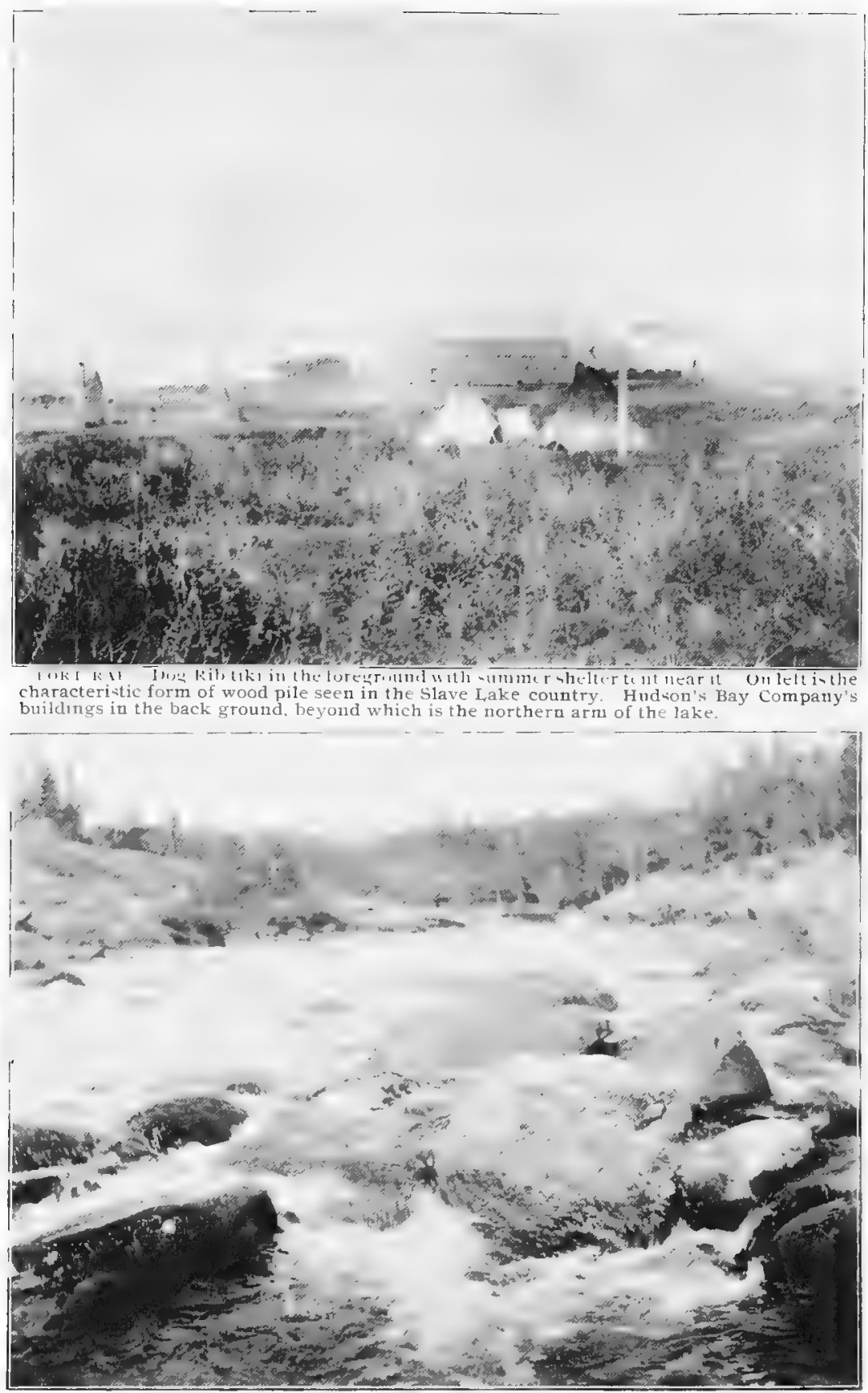

ONF OF TIIE MANI RAIIIS IN TIIE YRILOW KNIVIE RIVER. 
main route and is usually visited on but one inward trip, the second, but for the same reason as at Resolution the store was empty, and goods must be had to secure the furs which the Indians were preparing to carry in large canoes to the free traders across the lake.

Rae is situated at the extremity of a peninsula extending from the east shore nearly half way across the arm, there about five miles wide. Cliffs of a compact yellowish limestone rise to a considerable height ${ }^{1}$ and furnish the only exposures of Paleozoic rocks to be found on the east shore. The arm marks in a general way the western limit of the Archæan, but two isolated granite hills stand on the west shore, south of the fort. Five miles eastward, La Grosse Roche, the only elevation east of the arm, rises in a rugged granite ridge, on the eastern face of which the eagles find a nesting place. The narrow bays from the lake penetrate almost to the base of the precipice, and separate the low, rounded, granite hummocks into a multitude of islands.

The "Mountain" was formerly an island; the Dog Rib name - Nishy-kun signifies Island-hill post. The channel was filled twenty years ago, and is now dry and overgrown with willows. The timber has been stripped from the hill for fuel until it is now little more than a barren rock. Wind-swept at all seasons, five miles from fuel, which must be hauled with dogs, Rae is not an attractive spot, its only redeeming feature being the unfailing fishery before its doors. The country about Rae is wooded; the timber on the east shore is of little value for building purposes. Fair-sized spruce and banksian pine is obtainable from the west shore which soon rises to a plateau with innumerable ponds and muskegs, and some groves of - for that regionexcellent timber.

Two hundred yards from the big house, on the shore of a little cove called Sandy Bay, a few crumbling ruins of clay and stone chimneys mark the site of an "old fort," abandoned so long ago that nothing is known by the present inhabitants concerning it. Another fort once stood near the Big Point, twenty-five miles south, and still another ${ }^{2}$ had been established

1 Two hundred and twenty feet according to Captain Dawson. Observations of the International Circumpolar Expedition, Rae, p. xi.

Original Fort Providence. Masson, I.. R., Les Bourgeois, Vol. I, p. 40. 
in 1789 , on Marten Lake, nearly a hundred miles northwest of Rae. The present post was established forty years ago.

Rae was for many years the best provision post in the Mackenzie District, and furnished thousands of pounds of meat for the river transport; but the caribou have been driven back toward the Barren Ground, and the "hungry and desolate" post now receives scarcely enough meat and grease to supply its own people. As the caribou failed, the Indians resorted to trapping and musk-ox hunting, so that the place now makes a good return of furs.

Only two white men lived at Rae when I landed there; "Old Jock" Wilson, a chief trader in the Company's service, administered to a small portion of the earthly wants of the natives, while their spiritual welfare was presided over by Père Ruore, a Roman Catholic missionary from Southern France. Mr. Wilson had a peculiar habit of refusing to speak to any one for a week at a time if anything displeased him. He was assisted by Antoine Leviolette, a métis clerk, who with his wife boarded at the "master's table."

For the first ten days I lived in the big house. Our fare consisted of boiled dried caribou meat, so black, tough and covered with hairs that the sight of it soon became repugnant. One can eat a full meal of this dried meat, dry meat, dry turkey, or "scrap," as it is called, and feel just as hungry as before. Twice a day a plate of four small "cakes" of unleavened bread was placed on the table. For lunch on Sunday there was a rice pudding without milk, and no bread. At breakfast only there was sugar for the tea.

There was little to be done near the post, and I decided to make a summer trip toward the Barren Ground with several objects in view; to collect ornithological specimens, to secure caribou skins before they had assumed their winter pelage, to search for breeding places of water birds to be visited during the following year, and last, but not least, to get something to eat, as the unvaried diet of tasteless, leathery dried meat was growing intolerable.

I tried to engage the services of some of the Indians who, to the number of three hundred, were temporarily encamped about the post. Naohmby, "The Bear Lake Chief," was said to be the most intelligent and the most obliging of the Dog Rib 
leaders. I soon discovered, however, that arrangements could not be made with ease and dispatch. Naohmby had superstitious scruples about admitting a Mollah (white man) into their hunting grounds. I afterwards learned that he thought, as did all the Indians of the North, that if I sent down skins of the caribou to be mounted in my country, they would live there forever; which happy fate would induce all the vast herds that roam over the Barren Ground to migrate southward to join them. I did not know at the time why he found so many trivial excuses for not accepting the terms offered him - his young men already had their canoes loaded. Andrew and I could not paddle alone because there were many dangerous rapids. They would have to starve two weeks before reaching the caribou, which were so far away that I would lose courage altogether. His health was not good and perhaps he would stop somewhere and fish instead of making the long trip after caribou.

He said that they had all decided not to make their usual fall hunt for musk-ox, as the days were so short and the season so stormy, that it was altogether too dangerous an undertaking now that they had to go so far out from the timber. Five or six years ago, the musk-ox were found west of the Coppermine River, where a few clumps of stunted spruce maintain a foothold in protected situations, but each year the hunters had had to penetrate farther into the Barren Ground, and at least one of their number had been stricken with paralysis upon each trip. Three years before a hunter had been lost in a storm and never found. They had therefore decided to hunt musk-ox in the spring only. This was a great disappointment to me as I had expected to engage in this hunt during November and be prepared for an early start toward the Coppermine the next spring. Naohmby also discouraged my plan. None of his people ever saw the Arctic Sea; they were afraid of the Eskimos. They could not descend the Coppermine more than one day's travel from the point where they crossed it on the way to the musk-ox country. None of his brigade would accompany me down the river. Nor did he know of any locality where nests and eggs of water birds could be obtained.

The Yellow Knife River. The Indians would not allow me to accompany them on the caribou hunt. It was fifteen days' travel by canoe to the nearest point where the caribou might 
be found, which, in a wilderness of broken timbered hills and lakes, was too far to venture with Andrew alone, as he had come from Simpson the year before and knew no more about the country than I. I decided to make a reconnaissance on my own account toward the Barren Ground by way of the Yellow Knife River, which enters the lake sixty miles southeast of Rae.

I received directions as to the route from four different persons - who all disagreed. An Indian is usually considered a safe guide, though I have known of their sense of orientation being at fault. He may be a safe guide, but I never found him a reliable guide post. My two years' experience was too brief to allow me to generalize; I can only say that such sketch maps as they prepared for me were sadly out of proportion, and nothing further than the existence of a topographical feature could be established.

There were two hundred canoes at the post, but none of them were large enough for two men and the camp outfit, except those made especially for crossing the lake, which it would be impossible to use, owing to the portages. The shortest route to the Barren Ground is said to contain forty portages, so that the birch-bark canoes are made very light for carrying. They are thirteen to fifteen feet in length, two feet beam, with straight sides. The ends are curved upward and decked over with bark for a short distance. Owing to the long upward curve they are short keeled and cranky. They veer so easily that only one or two strokes can be taken before changing to the other side. Double-bladed paddles are never used, though an extra paddle is always carried for use in case one is broken in a rapid or a heavy sea.

Early on the afternoon of July I8th Andrew and I loaded our canoes on the rocky beach before the post, and "amid the applause of the multitude," I made my first attempt at paddling single-handed. It was vain to try to reassure myself with the thought that the spectators were half-breeds and Indians whose opinion, however expressed, could not effect my nerves. I did care very much, indeed, for the estimate formed by the fort métis has great weight with the Indians, and my success as a zoölogical collector depended to a considerable extent on just such trivial considerations. To those people, the appearance presented by a visitor at his arrival and departure is of the 


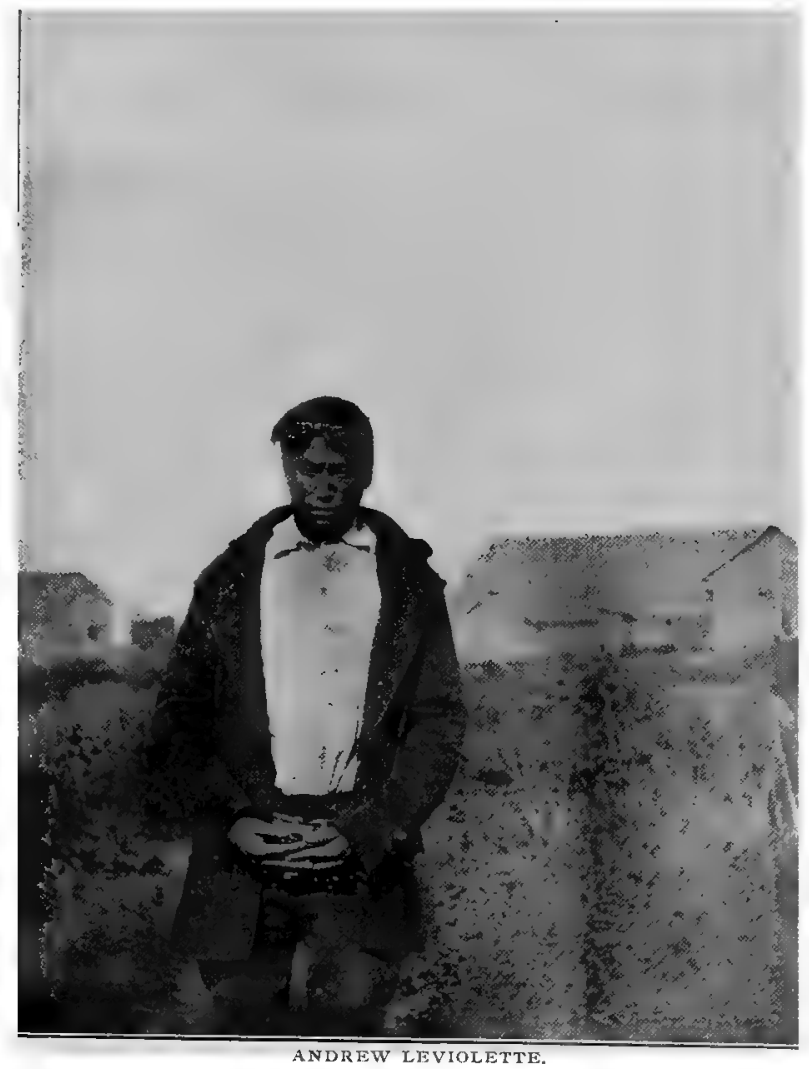



utmost importance. Then it is that the smartest colors are worn; the canoeist takes a deliberate stroke, but those beside him can see the bend of the paddle-blade, and the knotting of his muscles, as he grips the handle more tightly. My canoe seemed disposed, at first, to travel in a circle, and as the direction of the revolution could not be foretold, my companion found it safer to give me a wide seaway. There was little danger of capsizing, however, owing to the load which steadied the craft, and I soon succeeded in making tolerable progress.

The only shelter we had been able to get was a leaky tarpaulin, through which the rain, which came up that evening, dripped upon us for the next thirty-six hours, for the wind held us all that time in camp.

On the evening of the fourth day we passed a group of rocky islands, occupied as a breeding place by a colony of gulls, which rose at our approach and settled in the tops of the slender fir trees on the mainland. The unusual perch and the pretty effect of the evening sun shining upon the snow-white birds, a single one crowning each dark column of needles and cones, attracted even Andrew's attention.

Early the fifth day we overtook an Indian who, accompanied by his wife, was on his way to the Yellow Knife. They had just stopped to cook some Hutchins' geese, and of course Andrew became very hungry at sight of their fire and wished to join them. The old wife in plucking the birds, transferred tufts of down to her own person by frequent attention to the parasites with which all the Dog Ribs are infested. Stripping the viscera through her fingers and eating the choicer morsels, she continued to scratch, thus adding grease and more dirt to her grotesque crown. We continued through the winding chenals (anglicized as "schnys"), among low islands, where we often ran uncomfortably close to sunken rocks. The Indian couple guided us the rest of the day. They had two dogs in each canoe that lay quietly in the bottom until we gave chase to a flock of young geese, when they threatened to capsize the canoes by their attempts to stand on the gunwales. These dogs are trained when young to enter the canoes when called; any disposition toward restlessness is met with a vigorous rap from the paddle.

Within five miles of Yellow Knife Bay the islands became larger with high and precipitous cliffs of granite. 
The next day, which was Sunday, we were compelled to lie in camp by a northeast wind that covered the bay with white caps. In traveling in the North, Sunday is seldom observed as a day of rest. The natives perform the usual service and then continue their journey. Some missionaries remain in camp unless there is a fair wind blowing. Yellow Knife Bay is nearly clear of islands. The shores approach to within a mile of each other, inclosing an inner bay, where we passed a large canoe load of Yellow Knives on their way toward the river. At the river's mouth the current was scarcely perceptible. For the next six miles the channel expanded into three small lakes the first two of which contained islands. We kept to the left at a venture and found that we were following the shortest route.

The first rapid has a descent of about ten feet. It is necessary to make a portage in ascending the stream, but the Indians are said to run the rapids on the return trip.

While "Baron" Leviolette was descending this chute in a York boat thirty years ago, one of the oars struck a rock and killed the man holding it, as the handle was driven forward.

There is a fishery in the strong eddy at the foot of the rapids, where the natives set their gill-nets for whitefish and inconnues or "be-vwu-lĭ cu-g-ă," the Dog Rib name for the river being Be-vwu-li Te. This was the rendezvous of Little Crapeau's brigade of Yellow Knives. About fifty had already arrived and were encamped on the grassy slope below the gorge, through which the noisy stream finds its way from the lake. They were busily engaged in building small canoes for the inland journey to the caribou. The lake canoes were drawn out and left bottom up, in the shade of the trees, where they would remain until required the following spring to transport furs to Resolution. Large rolls of birch bark were lying about which had been brought from the delta of the Slave River, a hundred miles distant, by the canoe route. The canoe birch, Betula papyrifera Marshall, attains a much greater size on the south than on the north shore of the lake. The men were cutting prows and stern-pieces from dry spruce stumps which had the required curve. The women were sewing the squares of bark together with wattap (split pine roots).

Having obtained a few directions, which proved altogether 
wrong, about the route, we crossed the portage of a hundred yards, on the right of the rapids, and launched the canoes upon Prospect Lake. The Yellow Knife River is simply a chain of lakes connected by rapids and falls. The lakes are usually long and narrow, their general direction being north and south or northeast and southwest.

We followed the rugged cliffs on our left for half a mile, then turned to the left through a broad channel into the northern arm of the lake. We camped upon a small bay on the west shore near the site of another "old fort." The lake terminates in two bays. We entered the wrong one the next morning and had to turn back, finding that the stream entered the westernmost by a narrow oblique channel, not visible a hundred yards from the entranc:. We soon reached a series of cascades about a mile in length. The portage trail of more than a thousand paces leads from the east bank of the basin at the foot of the last chute to Fishing Lake, at a point some distance south of the river channel. This was our longest portage and I fully realized the advantage of having a light canoe by the time I had carried mine across.

We were unable to form any estimate of the extent of Fishing Lake as a wooded peninsula shut out the eastern arm from view. A mile and a half northward, we entered the river, where a ledge of rocks compelled us to portage half our load. Crossing a small lake we reached a cascade with a portage of fifty yards on the left. We were now upon the Nine Lakes, a long irregular body of water containing many islands. We crossed to the left through a narrow bay, then turned eastward. We searched for two hours in a bay to the left for a portage, which Andrew said he had been told existed there, and finally gave it up and entered the bay on the right, through which we passed without portaging. Passing a small colony of ring-billed gulls, we camped on the north shore where a cascade came tumbling from a picturesque little chain of lakes above us.

In the morning we chose the southernmost of three bays, before us and found a chute about fifteen feet in height, which we passed by a portage of fifty yards on the left. On our return trip we heard the roar of rapids in the direction of the northern bay, indicating the presence of a tributary of con- 
siderable size. This lake, perhaps the Lower Carp Lake of Franklin, is bordered upon the north by the "ironstone" formation and on the south by cliffs exceeding five hundred feet in height, containing conspicuous bands of feldspar and, in places, considerable quantities of mica. We encamped at the extremity of the lake. Our net yielding no fish, we moved the next morning to the river, which enters the lake near the middle of the south shore and camped at the foot of a short rapid. The next morning we found nothing in the net. We had a gull for breakfast, however, a sharp-tailed grouse for lunch and for dinner the staff of (Northern) life-dried meat.

Continuing our journey, we followed the channel of irregular width for a couple of miles to a large lake extending toward the southward. The sound of rapids directed us to the river, two miles down the east shore, where the chute is at least fifty feet in height. A few trees cut during the preceding winter were the only sign that the place had ever been visited. The portage of two hundred yards on the left was quite open. A spruce standing just above the rapids measured five feet in circumference and was of fair height, but it was noticeably larger than any other that I saw on the trip. The timber was much smaller than near the big lake, and the summits of the hills nearly barren. We followed the lake a distance of three miles eastward, then six miles northward, where from the summit of a high hill, which we ascended, we could trace its course for several miles toward the hills of the Barren Ground, which the Indians afterward assured us that we would have reached by crossing two more lakes. They never follow that route themselves in going to the Barren Ground. The site of Fort Enterprise must have been within our horizon.

The caribou were beyond our reach. The net yielded no fish and our supply of dried meat was nearly gone. I had become convinced that any attempt to collect birds in that region would prove unprofitable, and as geographical exploration was not one of the "scientific objects" enumerated in my instructions, I decided to go no further in that direction. I cut a lop-stick ${ }^{3}$ on the shore of the last lake to commemorate

1 A lop-stick is made by trimming the upper branches from an isolated spruce, leaving a tuft at the top. These are the guide boards of the country: Such a tree usually marks the halfway points between trading stations, the beginning of side trails, or wayside fisheries. 

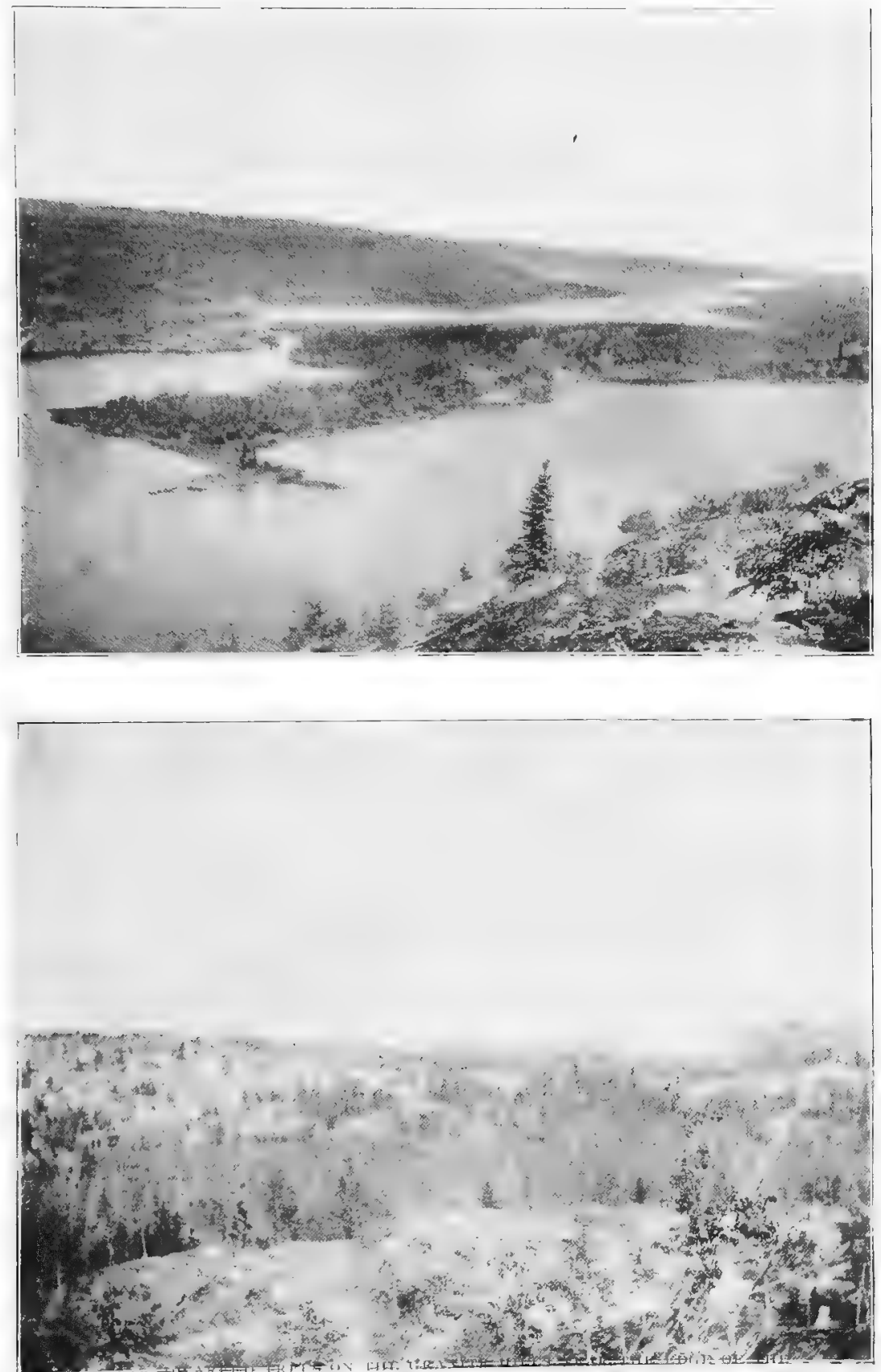
2

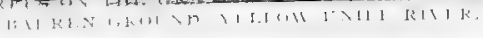






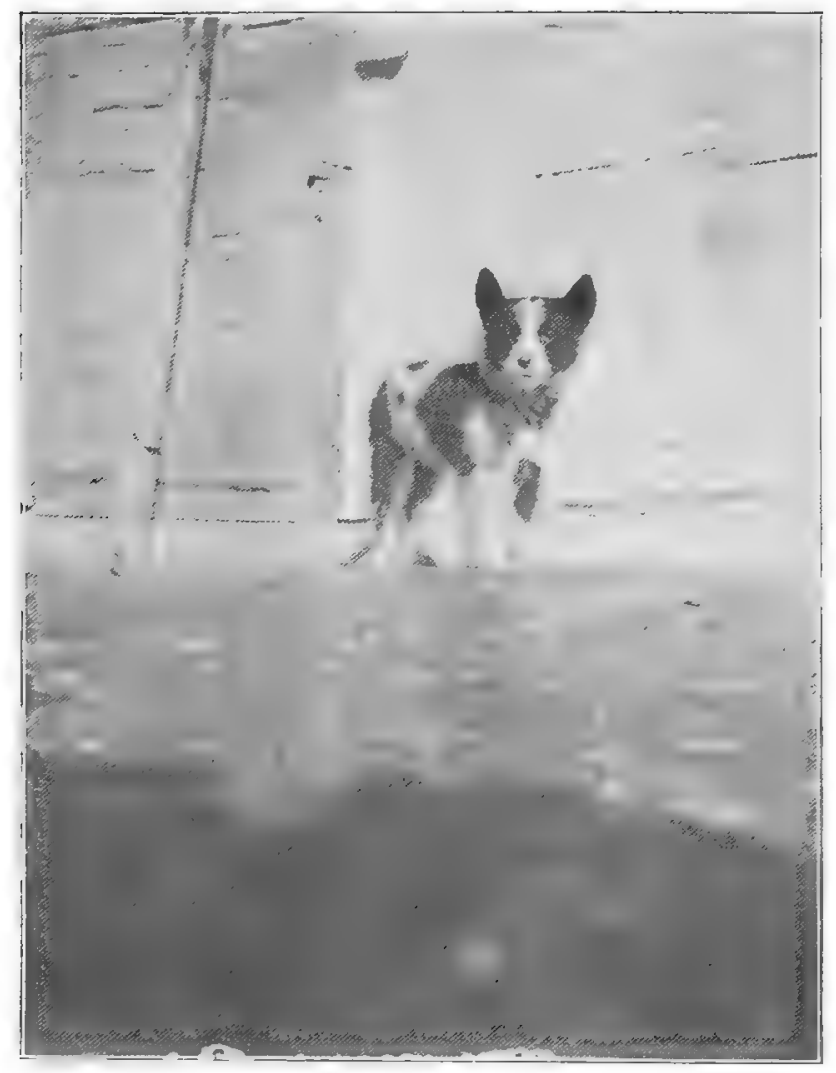

A WAIF FROM AN AMANIONED DOQ RIB CAMIP. 
the visit of an Iowan to that desolate lake, never before visited, I believe, by a white man. Franklin had followed the Indian route more to the northward.

We camped for the night at the head of the Nine Lakes, where the net, set below the falls, yielded, next morning seven yellow suckers, three whitefish, three jackfish, and a lake trout. A head wind prevented traveling that day. I occupied the time in taking photographs of the surrounding country and in collecting land birds, as I had done on several windy days during the trip. Another day's paddling brought us to Prospect Lake, where we found the Indians scattered along the whole length of the west shore. Only a few could use the portage path above their old camp at one time, so that they had been all day in getting under way. There were sixty canoes in all; some of them were new, some were old but patched with bright new pieces of bark, some were without the bark deck and seemed so old and fragile that one involuntarily looked to see how far the occupant would have to swim to reach the shore.

The men had lighter loads than the women. They paddled about in the bays after waterfowl. Shotguns were used, though wounded birds were often killed with steel-pointed arrows. Nearly every canoe contained two or three dogs, which were poor and thin, and naturally of inferior size, so that they added little to the load. The canoes contained a heterogeneous collection of muskemoots (bags of woven babiche), blankets, nets, lodges and other personal property. An occasional clean blanket or a powder keg indicated that a recent visit had been made by the owner to Resolution. They had been given a large amount of "debt" and had an abundance of tea, tobacco, and ammunition; yet every man that was not ashore came alongside to beg for these articles and many others.

We camped on the portage near the deserted camp, the lodge poles of which remained standing. All property not required upon the hunt had been cached on tripods of long poles, the lower half of which had been peeled to prevent the carcajous from climbing them. An abandoned Indian camp is not an attractive spot with its smoke-begrimmed skeletons of former lodges, its rags, heaps of hair, ashes, bones and trampled pinetops.

That day we had nothing but boiled suckers to eat, but the 
next morning we found several excellent whitefish and large inconnues in the net. We reached the Yellow Knife Bay at an early hour and found a heavy sea running, against which we slowly fought our way, being twice driven ashore to empty the canoes of the water that broke over the bows.

On the seventeenth day a beam wind blew steadily offshore and compelled us to paddle continuously on one side to prevent the canoe from veering head to the wind. On the eighteenth, and last, day of the trip a fair wind enabled us to sail. We lashed two poles across the canoes, which were thus securely held about fifteen inches apart. Two light masts, one in each boat meeting at the top, supported the blanket-sail. As the breeze freshened, the water piled up between the canoes and poured in upon us. The primitive sail was reefed until it was little more than a roll, yet we continued to make rapid progress. The islands protected us from the waves of the open lake; still we were running too great a risk. I would not have continued had I not feared that the "Wrigley," which was then due, would leave before our arrival. We were so wet with spray that we did not seek shelter from the rain which fell during the evening. We reached the post at 9 P. M., and I flattered myself at the time that I presented a much better appearance, as I glided easily up to the landing, than I had on starting out. As I look back upon it now, I fear that I did not present a very dignified appearance with a three weeks' beard, clothing wet and soiled, and limbs cramped from sitting in the canoe all the afternoon, with two or three inches of water in the bottom.

We had traveled over two hundred and fifty miles, and had secured a number of valuable birdskins, though the conditions were not favorable for such collecting. He who travels in a large boat, with men to manage it, need have no difficulty in making up half a dozen skins while the camp is being made. But when a man paddles his own loaded canoe all day, it will require all his pluck to induce him to attend to his duties as a taxidermist in the evening.

During my absence Mr. Joseph Hodgson had been placed in charge of the post. This gentleman, a native Manitoban, educated at St. John's College, had spent the last twenty years in the North. For several years he had had charge of McPher- 
son, for which place he was soon "thinking long," looking on his assignment to Rae as an undeserved punishment.

Another agreeable change was that the whitefish were improving in quality and becoming abundant. About fifteen were taken each night in a thirty-fathom net.

August 6 th, the next morning after we had reached the post, the "Wrigley" arrived with the season's outfit and the mails.

Canoe Trip across the Great Slave Lake. On the evening of August 27th I learned that a party of French métis would start the next day for Resolution, or "Slave Lake," as it is called by the Company's people. Alexis Laferté had secured a lake canoe and, assisted by his brother Vitall and an Indian named Émile, intended to move his family across the lake, where he was to enter the service of the free traders. I still hoped that I could "make the fall hunt" for musk-ox, if not with the Dog Ribs, then with the Yellow Knives who trade at Resolution. It was desirable that I should have a more satisfactory interpreter than Andrew. Finally, I wished to make arrangements to hunt buffalo from Resolution in midwinter. "Lixie" was willing to carry a passenger, if I "paddled my own weight." He declared that there would be "small little room " for baggage, and urged me to take only my blanket and a little provision. I took sufficient dried meat for five days, as that was the time usually required, under favorable conditions, to make the trip. The season of autumnal storms was at hand, but we relied upon the net and trout hooks to furnish us with fish in case we should be delayed. After starting, I found that the canoe would easily have carried a half ton more!

On the 28th the several members of the party occupied so much time in bidding their friends farewell, and alternately smoking a last "pipe" and drinking a last cup of tea, that it was nearly sunset before they were ready, when they concluded that it was too late to start, and the fair wind, which had been blowing steadily all day, was not utilized. The next day these ceremonies had to be repeated, so that it was late in the afternoon before we set off, paddling against a strong head wind. We traveled until a late hour to reach an alleged fishing place, though the net yielded only one small sucker in the morning. Shortly after midnight a heavy rain set in and continued until sunrise. My only shelter was the overturned canoe. The next 
morning a strong breeze blew from the northwest. As we were short-handed, no one thought of paddling when it was possible to sail, so we ran gaily before the wind, keeping clear of the rocks by good luck rather than by skillful management. In an hour we reached an island upon which was encamped an old Indian named Tenony, formerly the engaged hunter for Rae, now generally called "The Fort Hunter." He had killed a moose and a black bear on the mainland near by and, with a half dozen of his family, was then engaged in drying the small portion of the meat remaining after they had feasted for two or three days. Moose are rarely killed near Rae, and their meat is prized accordingly. As that was the height of the berry season, the bear was very fat. The sight of bear's grease and moose ribs was sufficient to confirm my compagnons de voyage in the belief that the wind was blowing too strongly for us to continue.

The rocks offered no shelter from the cold and piercing wind which drove clouds of mist, and occasionally rain, down upon us. Every available kettle was soon boiling; the newcomers provided the always acceptable tea, and Tenony hospitably invited us to help ourselves to the meat, which hung upon a temporary drying stage of crooked birch poles. The meat was eaten boiled, roasted, burned, and even raw. We had had our breakfast but a short time before, but that did not deter the métis from gorging themselves, a performance repeated at short intervals throughout the day. I had not yet abandoned the custom of eating but three meals a day, and cared nothing for the tea-drinking and the smoking with which they occupied themselves between meals. I had nothing to read, I was on a rocky islet where I could not collect specimens of any kind, and I could not talk Dog Rib-so that I was very glad when we again hoisted sail and parted from the most hospitable and most persistent beggar of the eight hundred comprising the Dog Rib nation.

I was simply a passenger, with no authority whatever over my companions' movements; I furnished tea for the party and wielded a paddle. Aside from the discomfort and hardship of such an arrangement, it gave the Indians the idea that I was a servant and not a "master," as they term the officers of the Company and explorers traveling through the country. As a 
result, it was hard to convince them that I really could pay when their assistance was required.

On the third day we were again favored with a fair wind which carried us nearly to Yellow Knife Bay. The wind died out in the afternoon and the métis amused themselves in firing at passing crows, shouting "vent derriere!" if the bird fell; notwithstanding the fact that two crows were killed, the breeze failed to freshen, and we paddled until an hour after darkness set in before reaching the bay where we expected to catch an abundance of both trout and whitefish. The canoe had to be hauled out each night as a change in the direction of the wind might cause its destruction upon the rocks. It required the united efforts of the whole party to beach it, as the pine lining was water soaked and heavy.

On the fourth day the wind blew with such violence that it was impossible to cross the ten-mile traverse before us. Not without danger of being swamped we set the net and several cod hooks for trout. Ordinarily lake trout may be caught along that shore weighing from ten to fifty pounds each, but not one could we catch during the trip.

High overhead the cry of the little wavey was frequently heard, as the V-shaped columns sailed swiftly southward, quartering upon a northwest wind. Several loons, attracted by the sight of the light colored canoe, or lured by a shining tin pan, approached within gunshot, but none were secured. The supply of ammunition was now running low; the last bullets were cut into cubes and rolled into rough shot in a frying pan. Thus far every gull, crow, or raven that came within range had been fired at, and the same laugh followed the shot whether the bird fell or escaped. The Indians' guns were of the pattern known in the country as "trade guns." They were of small bore, long, single- or double-barreled, muzzle-loaders of light weight. Twelve to fifteen pellets of $\mathrm{BB}$ shot were used to each load. These guns will carry ball with tolerable accuracy up to a distance of a hundred yards. The balls weigh twenty-five or twenty-eight to the pound.

At night Émile, who spoke French fluently, and Vitall would rise at unseasonable hours and gabble about fish and dogs, the principal topics of conversation with these people, with ceaseless repetition of "Wah wah," "Mon Dieu," etc., until sleep became impossible. 
Émile sometimes worked for the French missionaries, but usually depended on his nets and traps for a living. He understood no English, though he picked up a few words during the trip, which he would repeat upon hearing one of them used by the others, or when he was pleased at the result of a lucky shot. When there was an abundance of tobacco and provision he was good natured and ready to laugh at the most trivial circumstance; when we began to starve his face lengthened, the thickened nether lip drooped, and his complaints became loud and frequent that someone in the party was to blame for the wind and lake being vexed. When we returned a month later and found that an old crone had died about this time, at Rae, he of course saw that she had caused the adverse winds! After witnessing some of his gastronomic performances I could give some credence to the statement that he had once eaten a caribou in two days; at one time he had been a member of a York boat's crew of seven that was given a fifty-pound sack of flour for use while descending the Mackenzie-a journey of several weeks. They received the flour in the evening and ate it all during the night!

On the fifth day we moved to a larger island near by, where we found enough driftwood, that had been driven across the lake from the Slave River, to maintain a good camp fire. We crossed the traverse on the evening of the seventh day, and camped among the islands which for the next thirty miles are much larger than those of the Northern Arm. We would have been without provisions had we not reduced the daily ration to one-third the usual amount. We were four days in traveling the thirty miles of coast between Yellow Knife Bay and the Gros Cape. This point projects from the north shore toward the line of islands which separates the open western body of the lake from the long, island-dotted eastern portion. Our route followed the islands across to the south shore, a distance of perhaps fifty miles from the Gros Cape.

Taking advantage of a calm on the tenth day we crossed the first traverse, and stopped to boil the kettle on a small island. Émile started to gather driftwood, but came back at once shouting, "Les graines jaunes." We all scrambled up the rocks to a stretch of moss, covering the northern half of the island, where a fine patch of yellow berries, sheltered from the 
sun by the slope of the hill, still remained upon the stem, though it was past the season for them. The berries were like large blackberries in shape, but yellow in color and slightly oily in taste. ${ }^{1}$ This island, two hundred yards in diameter, had a little soil among the rocks, which supported prolific red raspberries, red and black currants, saskatoons, and gooseberries, while the surface of the moss was covered with yellow berries, creeping blueberries, cranberries, and crowberries. Our party, which (including Alexis' wife and three children) numbered eight mouths, swept across the island like a swarm of locusts. We crossed the next traverse that afternoon. It was about fourteen miles to the islands in advance, which appeared on the horizon as those behind us sank out of sight. The shifting wind might raise a dangerous sea in a few minutes; realizing this we paddled with all our strength, not missing a stroke for the three hours occupied in crossing.

The next day we continued a few miles among the islands of Simpson's Group until we were again stopped by a norther, that dashed the waves high over the cliffs, and made it impossible to set the net, even in the lee of the little rocky island where we camped. The scrubby timber had been recently burned, making it a charred and dismal place. The gale continued for four days with frequent showers of rain and sleet. We had nothing to eat and spent the time in drinking tea and lying in a sort of torpor. I was not hungry but became very weak, though I was able to paddle steadily from $4 \mathrm{~A}$. $\mathrm{M}$. on the fifteenth day until I I o'clock when we crossed the Grand Traverse, the most dreaded of all, and reached the shores of the Slave Delta at l'Isle de Pierre. We found a few gooseberries there which were fully ripened and as large as cherries. The vegetation was much more varied and luxuriant than upon the north shore of the lake. Waterfowl and muskrats were quite common in the delta, though without ammunition we could not secure any of them. After our feast of berries, having disposed of one whitefish, the total catch of our last station, we started for Resolution, now only twenty-five miles distant.

I Mackenzie mentions the occurrence of " another berry, of a very pale yellow colour, that resembles a raspberry, and is of a very agreeable flavour" (Voyages, p. 69), near the mouth of the Mackenzie River. This is probably the same species and would place its northern limit of distribution at the Arctic coast. It is called " tsuakah" by the Slaveys. 
As we were slowly making our way up one of the channels of the Big River that evening, we met a free trader and his interpreter who were hunting ducks. Mr. Nagle was expecting Alexis and at once asked me if I was M. Laferté! Little wonder that I was mistaken for a half-breed at the end of that trip! The hunters had a dozen cakes and three or four ducks in their canoe. Three muskrats were soon killed and boiled with the ducks. How delicious were those muskrats - my companions attempted to express their appreciation by calling them "castors;" the luxury of eating bread once more! We camped there for the night, as it was still several miles to the post. The next morning our blankets were white with the first heavy frost of the season. Our breakfast-comforting thought, the certainty of having a breakfast-consisted of ducks and rats. I did not stop to see whether my portion was of the former or the latter. A steady rain set in as we were pushing off, which continued until we reached the post at 3 Р. M.

I enjoyed the hospitality of the clerk in charge for a day and a half before starting upon my return to Rae, and I must confess that I lived to eat during that time. I found that the Indians would not arrive for several weeks, and that I could not hire an assistant for the musk-ox hunt at Resolution. I succeeded, however, in engaging an Indian to guide me to the buffalo country during the coming winter.

The free traders had been awaiting Alexis' arrival before sending a scow loaded with goods across the lake; this enabled me to return at once to Rae. We left the post on September I 5 th, and reached l'Isle de Pierre early on the third day. Here two men, who had helped us row through the delta, turned back, leaving us to depend almost entirely upon our sail. We started upon the fifteen-mile traverse with a favorable wind which suddenly shifted to the north and compelled us to run back toward the island. The lake became very rough and the waves soon broke over the quarter which we covered with tarpaulins. Had it been another mile to the island we would never have reached it. We remained there the next day, drying the goods and waiting for a fair wind. On the fifth day we crossed to the Gros Cape, where we again sought shelter from the north wind which howled across the lake for the next four days. On the 26 th of September we sailed into a channel 
covered with new ice an inch in thickness, which cut quite through the planks of the bow before the boat could be stopped. We several times ran upon sunken rocks among Les Isles Fortes, fortunately without breaking the scow. We reached Rae on the 29th, having been fourteen days on the return trip.

On the 29th Mr. Hodgson and I crossed the arm to the "Mountain," about seven miles south of the post, to hunt ducks in the numerous ponds in that vicinity. My companion had bagged almost a hundred there in a few hours the preceding week, but nearly all were gone when we arrived. The lake had frozen over on the $25^{\text {th. I }}$ It had broken up again the next day, but it was not safe to remain on the west shore when the temperature began to fall, as it did on the third day, so we made haste to embark upon our return. Three miles from the post a dense fog enveloped us; there was not a breath of wind to assist us in keeping our course; I undertook to steer my Dog Rib canoe by a pocket compass and, with the sluggish needle and the exceedingly sensitive canoe, it was a difficult piece of navigation. After two hours of wandering we reached the shore, and my canoeing was ended for the season.

October at Rae. When the lake had frozen over a large number of nets had been lost as the ice broke up and drifted southward. This interrupted the fishing, which was not resumed until the Igth of October, when the ice set fast for the winter. Over twenty thousand fish were hung during the "fall fishery" by the Company and the Roman Catholic mission; principally whitefish and inconnues. The whitefish obtained at Rae are small or medium-sized. The best fisheries on the Great Slave Lake are at Resolution, Big Island at the outlet of the lake, and recently at Hay River, where a storm, accompanied by a "big wave," in I890, brought a large species of whitefish to the fishing grounds off the mouth of the river, where it has since remained. Previous to that time the whitefish taken at that fishery had been similar to those at Rae, not exceeding two or three pounds in weight. The lake trout, Salvelinus namycush Walb., is caught in considerable numbers at Resolution during the winter, but is seldom seen at Rae, though common at Trout Rock, twenty-five miles southeast of that post. Inconnues, Stenodus mackenzii, weighing ten to fifteen pounds, are caught in considerable numbers but are of poor quality. They dete- 
riorate as they advance southward from the Arctic Sea. Jackfish, Esox lucius Linn., and suckers, Catostomus longirostris, are somewhat common. The loche, Sata maculosa, is also caught, but only the roe and liver are eaten. This species (if it be the same) sometimes attains very large size; Count de Sainville, whom I afterward met at McPherson, assured me that he had measured a loche, which he had caught in the arctic Red River, that was four and one-half feet long. A stray herring was taken in one of the whitefish nets, the meshes of which are usually too large for this species, seldom found above the mouth of the Liard River. (I did not see the specimen myself.)

The isolated hills about Rae are covered with willows and low bushes; these attracted large numbers of ptarmigan, Lagopus lagopus Linn., which made their appearance on the first of October. They were just assuming their winter garb, and as the permanent snow did not come until the $23 \mathrm{rd}$, their white plumage rendered them very conspicuous amid the grays and browns of their environment. A score of hawks, Accipiter atricapillus (Wils.), soon gathered about the post to prey upon the ptarmigan. The latter when pursued flew high and straight away, seemingly holding their own in the race. If swooped down upon when on the ground, they merely crouched as if relying on their usual safeguard-protective coloration. More than once the hawk was bagged as he rose with his victimdead-in his talons. Until driven away by the dogs and the métis boys, the ptarmigan came about the buildings without fear. It was not an unusual thing for me to shoot them off the roof of my cabin for breakfast. Pot hunting, indeed!

The winter birds were noticeably fewer in number of individuals, and also of species than at the station occupied the previous winter on the Saskatchewan.

\section{Periodical Events Recorded in the Journals at Rae.}

Ice broke up, June Ist, 1857 .

June $7^{\text {th, }}$ I $85^{8}$.

May 30 th, 1859 .

June $3 \mathrm{rd}, 1883$.

June 23 rd, I 884 .

June I 8 th, I 885 .

Lake froze, October I9th, 1857 .

October 6th, 1864 .

October 28th, I88o. 
The ice clears close to the post nearly a month before it disappears beyond the Grosse Isle, ten miles to the southward. It does not disappear au large-beyond Big Point, until late, sometimes the middle of July. In 1859 this entry occurs for June 2oth: "Ice-bound among the islands thirty miles southeast of the fort, and the mosquitoes in myriads." It will be observed that the ice broke up at the post, where the arm is much narrower, on the zoth of May.

August I2th, I884, the journal reads: "Snowstorm all day." A record of the temperature was kept, with some interruptions, from November, 1883, until May, 1885. No other meteorological data have been recorded in the Rae journals.

During the winter of 1882-3 Captain H. P. Dawson, with three assistants, made observations on meteorological and magnetic phenomena at Rae. This point was chosen because it is the nearest of the Hudson's Bay Company's posts to the magnetic pole. 


\section{CHAPTER VI}

\section{WINTER TRAVEL}

"THE Caribou Hunt. Vague rumors had reach Fort Rae con1 cerning the whereabouts of the "deer" during the last week of October, but it was not until the first of November that a party left the post to hunt them.

A few years ago the Barren Gound caribou appeared about the fort regularly upon All Saints day. They were often killed from the buildings, and throughout the winter might be found near the post. In 1877 an unbroken line of caribou crossed the frozen lake near the fort; they were fourteen days in passing, and in such a mass that, in the words of an eyewitness, "daylight could not be seen" through the column. They are now seldom seen within several miles of Rae.

The "Fort Hunter," Tenony, with seven of his followers, was just starting upon a seventy-five mile journey toward the north on the evening of the first, when I learned of his intentions, and after I had agreed to furnish a few skins of flour, tea, and tobacco, and to pay a skin a day for a dog driver, it was settled that I might accompany them into the hunting grounds where the chief, Naohmby, had objected to my going three months before, on the ground that all the game would desert the country if pursued by a naturalist.

I loaded my sled with thirty whitefish, three days' provision for the dogs, and fifteen pounds of dried meat for the boy; during the trip I shared alternately with each, the rank, hung fish driving me to dried meat, and the leathery slabs compelling me to return to the fish.

As the "brigade" only intended getting clear of the fort that evening, I preferred to remain and make an early start the next day. We left the fort at daylight on the second, Yahty running before the dogs. Our course was northward for twelve miles, 
to the end of the Northern Arm of the Great Slave Lake, whence a channel, a hundred yards in width, called Willow River, continues for half a mile before expanding into a small lake extending toward the northeast and connecting by a number of "schnys" with Lac Brochet. Following the eastern shore of the small lake, we crossed a short portage and, traversing a narrow channel for a couple of miles, reached Să-kăton Tu', the Lake of the Bear's Shoulder. This body of water must exceed twenty-five miles in length.

We did not succeed in overtaking Tenony, but encamped near the end of the lake with an Indian, who, with his ten year old son and three miserable giddés, was also in quest of the caribou. He carried a powder horn differing from any that $I$ saw in the North. It was made by boring or burning out a section of the beam of a caribou's antler. He would smilingly beg for tea and tobacco, not becoming in the least disheartened by repeated refusals. I was glad to escape his importunities by leaving camp at $4 \mathrm{~A}$. $\mathrm{M}$. The brisk trot of our well-fed team soon carried us out of reach of the yells of the giddés as the lash was unsparingly applied in his efforts to keep up with the "Mollah" who had such quantities of "lee tea" and "tobah." Passing a couple of miles of short portages we reached another large lake, called by the Dog Ribs, Kwĕm-tă Tu', the Lake of the White Rock, where we found Tenony encamped.

The Indians had been aroused by their dogs greeting our approach with barks and howls, and were huddled behind a roaring fire with their blankets, once white, now a dirty gray, thrown over their shoulders, their hands outstretched toward the welcome blaze, while they guarded the few frozen fish which were thawing and burning at their feet. Behind them a confused mass of dog harness, wrappers, and flat sleds formed a barrier to keep out a score or more of giddés, which were crowding about the camp and fighting for an advantageous position from which to watch for the few bones that escaped their master's teeth. After drinking tea, we followed the lake shore toward the northwest, where a range of granite hills, called Sah-me-t' ie-kfwa, (Petitot) rose high above the general level of the somewhat rugged country about them. When close to the hills, we discovered a small band of caribou, toward which the dogs started at their best pace, barking and straining at 
their collars, and urged to greater exertion by the men, who shouted, "Ayee ecwoh, m'nitla!" there are the caribou, now, go! The alarmed caribou were dashing about in all directions, yet managing to keep out of range, though several shots were fired before they entered the timber. Around us rose the precipitous snow-covered mountains through a gap of which a large stream entered the lake, its cascades giving off clouds of vapor. High above us a bald eagle wheeled in majestic flight, with white crown and crissum flashing in the light of the rising sun. Cutting our way through a brûlé we reached another lake, upon which there was an abundance of fresh tracks. An hour later I left the others and started down the lake with the boy before the dogs. Three or four bands of caribou, perhaps fifty in all, soon came out upon the ice. Yahty ran toward the nearest of them followed by the dogs which dashed past him at full cry as soon as they discovered the caribou. I was seated upon the sled while Yahty, holding the sled line, ran in the cloud of snow which trailed out behind.

The caribou stood motionless until we were within a couple of hundred yards before making off; they soon stopped, side on, to survey their pursuers, snuffing the air for a moment; then they would throw back their heads and leap high in the air, and again dash away at a swift run, passing patches of smooth ice without a misstep. The drifts were small, but the snow was well hardened, making a rough surface for the swift-flying sled. Just as I would be about to pull the trigger, after taking hasty aim, a sudden lurch would nearly dislodge me from my seat and perhaps send the muzzle of the rifle skywards. I succeeded, however, in killing two and breaking a fore leg of another which ran with undiminished speed, in fact, led the band as they entered the timber and so escaped.

Placing a row of pine boughs at intervals of fifteen or twenty yards quite across an arm of the lake, we concealed ourselves on shore, and waited the appearance of the caribou. Only one band approached our barrier, which they followed some distance, but did not venture to cross; they turned away before coming within range. The following day we were more successful in employing this, a common device of the Dog Ribs.

That evening we feasted until a late hour upon the first caribou meat of the season. Several heads were skinned and hung 
from poles before the fire by the mitten cords of the owners: and willow hooks. As soon as the outside was roasted the jaw was turned back and the tongue, one of the choicest bits of all, slightly cooked. The dogs were well fed for the first time in months; we gave them the quarters only, and cracked the long bones for the marrow. which, raw or roasted, is one of the greatest of Dog Rib luxuries. Look down in pity upon "the savage and his marrow bones" if you will, but you might perhaps relish that same marrow if you had "hustled" for those bones yourself as I had done, or you might, after running fifty miles, pass your plate a second time for bouillon made of blood carried to camp in a caribou's stomach. Even the tendons were eaten, and the feet also, after roasting them until the hoof could be knocked off. Although I lived some time with the Dog Ribs, and spent over a year in their territory, I never knew of their eating the contents of the caribou's stomach as do the Eskimos. The unborn calf, the udder of a milk-giving cow, the tongue, the marrow and back fat are the parts held in highest esteem.

Tenony fulfilled his promise of returning after "five sleeps," but marched fifty miles against a heavy gale of wind upon the sixth day to do it.

The caribou came but little nearer during the winter of I893-94. I made three other trips in search of them, and traveled five hundred miles in all, driving my own dogs after the first hunt with Tenony. Out of a large number secured, I selected eight choice specimens, and during the winter obtained the skin of an albino. Albinism is of rare occurrence among them. One of the oldest Dog Ribs assured me that he had never seen a "white deer."

Sledge Trip Around the Great Slave Lake. The winter packet starts from Simpson, the central post of the Mackenzie District, on the first of December. On the same day a dog train leaves Rae to intercept the outgoing mail at Providence. Having secured specimens of the caribou, I was ready to cross to Resolution and engage in the buffalo hunt. Without an Indian to run before my dogs it would have been dangerous to attempt to follow the route traversed in the autumn, so I decided to accompany the packet train around the west end of the lake, thereby doubling the distance. Of late years the winter route 
to Providence has been shortened by using a blazed trail through the bush, instead of following the north shore to Big Island and then descending the Mackenzie. Including its interminable windings, the new route is about one hundred and sixty miles in length.

Henri Laferté, a métis servant, drove the packet team and, Yahty, a strikingly handsome young Indian, whom I had had with me on my first caribou hunt, ran before the dogs. The trail had not been opened for the season, the snow was therefore soft and the way blocked by fallen trees; we were also delayed by waiting for daylight each morning before starting, on account of the trail being so faintly marked in the openings; we often searched for some time to find the exit from the numerous lakes and ponds. The snow was not yet deep enough to cover the fallen timber against which the head of the sled lodged every few minutes. The sled frequently caught against standing trees at the sharp turns; these sudden stoppages injured the dogs' shoulders, and the poor beasts became dispirited and sulked along at a slow pace. At each halt it was necessary for me to wade around the sled, to lift the head of it clear of the obstruction. My small snow-shoes sank deep in the snow and made this very fatiguing work. I helped the team by pushing the sled with a "pushing-stick" attached to the middle of the load.

On the morning of December 7 th we started at two o'clock, expecting to reach Providence that evening. We soon lost our way in the darkness. Yahty and I curled up on our snow-shoes and slept as comfortably as the position and a temperature of thirty-eight degrees below zero would permit, while Henri tramped around until daybreak looking for the trail, though how he could distinguish it, even in broad daylight, was a mystery to me. Yahty missed his way in the afternoon, and we were at last forced to camp, though only seven miles from the post. We were in the middle of an extensive marsh, locally known as the "First Prairie," where there was very little brush for a camp floor and only a few sticks for fuel. Henri and Yahty seemed quite contented with the situation, but the thoughts of the comparative comfort and the companionship of people of my own race at the post made me very anxious to push on, but, as on several other occasions during my journey, the custom of the 
country had to be observed; we must not "arrive" at a late hour.

We reached Providence on the eighth of December. The river packet had arrived from Simpson, and a day and a half later it was sent on in charge of "Old John," the pilot of the "Wrigley." He has driven the packet train across the Great Slave Lake, the most dangerous portion of that two thousandmile mail route, for the last nineteen years. In the bush strong winds cause some hardship, but do not prevent traveling as they do upon the lakes and Barren Ground. "Old John" had many times starved both himself and dogs while a gale had blown itself out, as no extra provision is taken for delays.

The letters were carried in a pine box lashed on the ordinary flat sled. The dogs were smartly dressed in tapis, and the boy who ran before the team wore a pair of new mooseskin mittens which were covered with a mass of beads; they had a manycolored cord attached that passed around the wearer's neck. His leggins, of blue strouding, reached above the knee and had a broad stripe of beadwork along the outer seam, reaching from the ankle to the gay-colored garter; a pair of new trousers, a fine-cloth capote, and beaded moccasins completed his costume.

My dogs had some difficulty in keeping pace with the fresh packet team. I was greatly in need of a few days' rest myself, and shall always remember that run of a hundred and seventyfive miles as one of the most trying trips that I ever made.

Le grand froid ${ }^{1}$ of winter had come. The temperature ranged from fifty to sixty degrees below zero, Fahrenheit. If exposed to the wind while on the march, as we were on the broad river and on the lake, it was difficult to keep our faces from being frozen. At night the intense cold seemed unendurable. We never had any shelter but our blankets; it would have been impossible to have kept a fire burning all night, as the coals thrown off would have burned our blankets, and the quickburning spruce would have required frequent renewal. Toward morning I was nearly always awakened by the bitter cold, which sometimes gave me the impression that my feet were certainly frozen. I sometimes started the morning fire myself.

"Pronounced "frete" by the métis who give the sound of è to the diphthong oi. 
Although there was little comfort in a bed, where I was literally writhing from cold, it was not pleasant to open my blanket covered with frost and snow, and search in the darkness for a strip of birch bark with which to ignite the charred sticks at our feet. After I had put a kettle filled with snow, containing a handful of black tea, on the fire, it was easy to rouse the men; the rattle of a granite cup against the kettle or the cry "lee tea" always brought them up at once. After eating our dried meat, each man loaded his sled as rapidly as possible. It was necessary to use our bare hands in lashing the sleds, which was the coldest work of the day.

We became comfortably warm after running a few minutes, and had accomplished nearly half our day's journey before the first gleams of dawn-"small daylight" - had appeared; though it rose but a short distance above the horizon, the sun's appearance had a wonderfully enlivening effect on our spirits. The boy before the dogs ran with a free and untiring step, the whips cracked merrily, the bells with a hundred tinkling tongues proclaimed the joys of light and life in speeding over that diamond-studded plain of purity.

Toward evening the boy stopped more frequently, the whips fell mercilessly on the heavy coats of the tired team, our limbs moved mechanically as if they had lost the sense of feeling, our hands became so numb that we sometimes had to use our teeth, instead, in loosening the sled lines.

The ice formed a solid mass in my beard, causing my voice to sound muffled, and in time froze against my cheeks; my eyelashes were nearly always covered with frost, which seriously interfered with the sight; the vapor from our heated bodies gathered in feathery crystals on the hair of our capotes, so that we were quite indistinguishable from one another at a little distance, in fact, hardly recognizable as human beings.

Before darkness set in the dogs were halted and all entered the bush, ax in hand, to gather fuel. After piling up half a cord of dead spruce, "Old John" and I scraped away the snow with our snow-shoes and laid down a thick carpet of boughs on which to spread our blankets. The boy brought wood for the morning fire until the camp was finished, when he lighted the fire while we brought up our sleds. The dogs threw all their reserve strength into the effort necessary to force the sled 
through the soft snow, plowing their way over logs, riding down saplings and displaying desperate energy until they reached the dark floor of the camp, where they usually "made themselves awkward" before the sleds were dragged into position at the back and sides of the oblong bed of boughs. After throwing out the blankets and dog fish, we relashed the sleds and covered them with brush to prevent the dogs from gnawing the mooseskin wrappers and the braided caribouskin lines. The mooseskin harness was also hung out of their reach or used as pillows. The fire extended along one side of the camp, the logs being laid up in the form of a very obtuse angle pointing toward us. A pole resting on the walls of snow on either side was placed at our feet, against which the sixteen fish for the dogs were leaned to thaw. The exterior was often burned before the fish were rendered flexible enough to be bent by the hands--when they were considered thawed enough. As soon as they had been taken from the harness the dogs curled themselves up in the snow and laid very quietly, until we rose to give them their ration, when it behooved the cook to look to his kettles, for the dogs were sure to leap over the outer ends of the logs in their excitement. We then ate our meal of dried meat or hung fish. During the evening the foot gear was changed and dried; no other change of clothing was made for the night. Before the fire died away the men ate a second meal in which I never joined them.

We used the provision bags and such portions of our load as the dogs could eat for pillows, where our heads did not long rest before we were overcome by the sleep of exhaustion, which was not to be disturbed by the dogs running over us or lying on top of our bodies. The métis or Indians use a single three- or three and a half-point blanket in summer and in winter add a robe of caribou or hareskin. I have seen them sleep without robe or blanket in very cold weather. Each individual laid upon his vest, if so fortunate as to have one, which was not often, and drew his capote over his head and shoulders; every hour or two he rose to add fuel to the fire, and two or three times during the night tea was boiled and a lunch eaten. The natives make a narrow camp and curl up very much after the manner of the hauling dogs. I always had to lengthen my sleeping place by scooping out a pit at the back. Upon this trip I used a sleep- 
ing-bag made of woodland caribouskin, which I had brought from Iowa City. I afterward found that the light Barren Ground caribouskin robes, such as the natives used, were lighter, warmer, and a great deal more convenient. I started from Rae with two double blankets, but left one pair at Resolution. On the musk-ox trip I used a single blanket, and during the last week gave that away and used the robe alone-and slept about as comfortably as when I had the sleeping-bag and four blankets!

Our first day's travel was up the Mackenzie where we experienced some difficulty in finding sufficient fuel, the dry timber having been used by the many trippers hauling fish from Big Island to Providence. We reached Hay River on the third day, where we spent the night at the house of Mr. T. J. Marsh, one of the most self-sacrificing of northern missionaries. With no companion save a Scotch servant, who has since been ordered elsewhere, he is devoting his life to the little band of Chippewyans who have built cabins at the mouth of the river, upon the site of an old trading post. When he first went among them they demanded exorbitant wages for their services, but their attitude changed to one of respect when they found him quite able to do without their assistance. With the aid of his servant he attended to his nets, cut and hauled the logs, built a dwelling house, and at the time of my visit had a large church building nearly completed. The natives were independent, owing to the excellent fishery before their settlement; the long continued coaxing and wheedling of the traders had made them impudent. They were dressed in capotes woven from strips of hareskin. The round-cheeked and grimy youngsters appeared to be warm and happy in their single thick and fluffy combination garment.

Mr. Marsh spent the night in writing letters. He accompanied us a few miles the next morning, and as we parted at daybreak, I felt as if I were saying farewell to the friend of years instead of to an acquaintance of an hour. We reached Buffalo River that evening, where we passed the night in the single cabin which had been built there by a Chippewyan chief. It was the largest and cleanest that I ever saw occupied by either métis or Indian.

We failed to reach our destination on the fifth day owing to. 
the bodions, ${ }^{1}$ which made our progress slow and fatiguing. Five miles offshore we found the lake free from bodions, and in places swept clear of snow. The dogs slipped and floundered as soon as all four of them were on the bare ice; we could not help them, for our snow-shoes slipped so easily that it was difficult to maintain our own equilibrium. The foregoer of the packet team at last refused to cross the ice at all but circled around on the irregular ridges of snow much to "Old John's" disgust. Early in the day we passed Sulphur Point, where small springs emit strong sulphurous odors. We encamped that evening on one of the Burnt Islands, which we had difficulty in reaching owing to the high and vertical wall of ice that surrounded it.

Early on the I 5th of December we reach Resolution, where I was a second time hospitably entertained by Mr. Mackinlay, the clerk in charge. I then enjoyed a fortnight of much needed rest. I had traveled over eight hundred miles, on my own snow-shoes, in company with different parties of natives, each of which had tried to "plant" me. The trip from Rae had been a "hard" one. The dogs were nearly worn out, and unfortunately there was no extra provision at the post for them. The stock of supplies on hand was the smallest that there had been at that season for years. Easterly winds-offshore-in September and October had made the fall fishery almost a failure. No boat had been despatched to the east end of the lake, where large quantities of dried meat and grease might have been obtained from the caribou hunters. The stock of flour was nearly exhausted and all other supplies for the clerk's table had been lost by the wrecking of the boat containing them in the Athabasca Rapids. The post was subsisting principally on fresh lake trout, caught with hooks set through the ice, from one to five miles out in the bay. I could buy these for one $\mathbf{M B}$ apiece but they were too heavy to carry for dog feed, and unsuited for continuous use as food. The outlook for the projected buffalo hunt was not bright. I could not induce Little François, the Chippewyan hunter, whom I had engaged in the autumn, to start until after the New-year's festin. There were no other men available, I had to await his pleasure-and he knew it.

1 Broken ice pushed up by a storm at the time of its setting fast in the fall. 
The Yellow Knives. On the 22d of December small bands of Yellow Knives began to arrive from the camps across the lake. Each party contained eight or ten men with four or five trains of dogs. At the last camping place clean shirts and moccasins had been put on over the old, and their hair and faces had been freshly greased. Dashing up to the big house, with cracking whips and jingling bells, they crowded into the clerk's office to shake hands and give their "news" before going to the store to receive their "arrival gratuity," consisting of two potspints-of flour, a pot of tea, one of sugar, and two plugs of negro-head tobacco to each man, and a somewhat larger allowance to the chiefs. After begging meat and dog fish, they betook themselves to the cabins of the Company's servants to eat their allowance, which is never spoiled with keeping. Some of them brought a few pounds of dried meat for which they received the regular price and a "present" besides. They then begged for half of it upon which to live during the two or three days spent at the post. "Surely the master will give us a little meat when we are starving, for we have brought meat from far to please him."

Zinto was the most popular leader among them. He was a tall, fine-looking Yellow Knife, though somewhat disfigured by a ferocious squint. Black Head, another prominent chief, kept close to Zinto while the latter was about the post, either from a desire to hold himself aloof from the vulgar herd or to see that $Z$ into did not receive more favors than himself from the master. Black Head had a round, stolid face, with a pug nose, and an expression that was "childlike and bland." $\mathrm{He}$ asked for and obtained a New-year's gratuity, saying that he was going back to his camp at once. Just before New-year he reappeared, ready for another ration!

After their festin they gathered for a big talk. The chiefs seated themselves in chairs, the others sat crosslegged on the floor. Zinto talked half a day, using frequent and graceful gestures. The other chiefs also spoke at length, though of course a great deal of time was consumed in interpreting. Michel, the métis interpreter, translated Mr. Mackinlay's English into the Yellow Knife dialect, which in turn was interpreted in French, making a sort of triangular conversation that was rather amusing to me. Each chief wanted to know why the 
Indian did not get fifty skins instead of thirty for musk-ox robes? Why had he not received the gun promised him, or the suit of clothes, or other present? Would they receive a thousand and one things when the steamer came in July? They wanted iron kettles, field glasses, rifles, match safes, goggles, and medicines, pencils and paper for writing letters in syllabics when sending for supplies, and if the master would give him some of his own tobacco, and a pair of his own trousers the speaker's heart would be glad!

Mr. Mackinlay replied that he was paying them as much for robes as the dealers in the white man's country received for them dressed and lined; that the steamer would bring an enormous stock in the spring of much better goods than the free traders could bring in; that he would give "debt" to help his Yellow Knife brothers, a thing which no other officer in the service was allowed to do. It all ended by his going to the store and dealing out a few skins of tea, tobacco and other supplies, to be paid for when the robes were deliveredif the hunter had been so fortunate as to secure any furs in the meantime which he had not sold to the free trader of whom he also endeavored to obtain as much "debt" as possible.

It was cold work for the "master," measuring dry goods and counting bullets in the storeroom without any fire. During the summer season, when there are hundreds at the post, only one is admitted to the shop at a time. The door is kept locked behind him until he has made his purchases before the broad, high counter, over which the clerk must clamber to reach the goods. As soon as he goes out he is surrounded by his friends who overhaul his bundle and give him such varied and bewildering advice that he would be pleased if permitted to exchange everything.

On Christmas eve a midnight mass was celebrated at the Roman Catholic mission. The church was crowded with natives, who were quite overcome by the splendor displayed, particularly by the scores of candles, the burning of which appeared to be a sinful waste of several pounds of appetizing and palatable grease. I no longer ridiculed their fondness for grease. I had learned to value it above all other luxuries of the country, and would not have exchanged a block of it, while on the march, for the richest plum pudding ever made. 
On Christmas day all the métis and Indians visited the big house, and drank the twenty gallons of tea, which there awaited them; they then moved in a body to the free trader's tea kettles, to the Anglican mission, to the school, and to the Catholic mission, after which they separated to enjoy a good square meal in the métis cabins.

The bush Indians left the post the next day. At New-year a different crowd gathered for another festin. The day opened with a salute from a score of guns before each door; it was spent in feasting and closed with a dance which was continued until 8 A. M., January 2nd. The Indians danced in one of the cabins. They sang improvised songs, descriptive of their hunts or their relations with the traders, or chanted in monotonous but not unmusical syllables, such as Hi! He! He-yah! or Heeja, Hooja! accompanying the voice with hand-clapping and drum-beating. They danced, or rather stamped, in a circle, swaying their bodies from side to side. Sometimes the dancer bent far forward, balanced upon one foot, his whole body quivered, and his voice sank to a guttural huh, huh. Tonality was subordinated to ungraceful and violent body action and the effect, as a whole, was not pleasing.

The whites and mettis danced their jigs and reels in the big house. The festin disposed of the last of the imported provision. Meat was more abundant at the camp, for which the Indians made haste to depart next day.

The Buffalo Hunt. As Little François, in contracting to guide me to the buffaloes, made his demands according to the present advanced ideas prevalent among the Chippewyans, I will narrate the circumstances somewhat in detail. Indian laborers are accustomed to receive daily rations for themselves and families, who, as they never make any provision for the future, would starve the next day if the net and gun failed them. They are given a small plug of negro-head tobacco each day; this is smoked. I never saw a Northern Athabascan Indian chew tobacco.

François demanded double wages; he was getting too old to walk before my dogs; he must take his own team and ride part of the way; another man must, therefore, be hired to walk before the dogs. Henri was willing to go for the same wages that François received. The latter concluded that if I furnished 
the old wife with rations, they must be such as were used at the post; she must have flour and bacon. A woman usually receives a half ration, which is more than an ordinary white man would eat. François thought that fifty pounds of flour and twenty-five of bacon would perhaps keep her from actual starvation for the next fifteen days, but for fear it would not, he wanted another week to hunt moose so that she could have some fresh meat. It was really touching to see how solicitous he was for the welfare of his childless spouse. He then left the post, telling the interpreter to have me bring plenty of tea and tobacco. I took every pound of meat and flour that I could purchase at the store, from the mission, and the free trader, and then did not have enough.

On the 8 th I went to his house at the mouth of little Buffalo River, and found, as I had expected, that he had not gone to hunt moose, but had asked for delay in order that sufficient time might elapse before again visiting his traps which were upon our route. When I reached the house, the old wife wanted tea and tobacco. I had brought compressed tea, for convenience in carrying; this did not suit their cultivated tastes. They were "thinking long" for meat, and would I not give them a supper from the scanty stock on my sled? Could I not give her some more sugar? The men would require plenty of matches, and could I not spare her a few boxes also? François was quite right in making as good a bargain as possible, but he was not so unsophisticated as his ancestors, who would have served me for the sake of the extra buttons on my capote and perhaps one cup of tea on the trip. I purchased here ten sticks of the smallest whitefish that I saw anywhere in the country. They had been caught in the Little Buffalo River, and did not exceed one pound each in weight. I left eight fish for my dogs on the return trip; these were stolen during my absence.

We started at 9 A. M., January 9th, and followed the river for perhaps eight miles. Its course is remarkably straight for that of a small stream flowing through a low alluvial plain. It is sometimes used as a canoe route to Fort Smith, a portage being made into the Slave River. Henri said that its water was brackish, owing to the salt springs near its source. It is mapped as a single, unbranched stream, but it is formed 
by three creeks flowing from the southwest. The first flowed in a narrow, winding channel, cut but little below the plain; the second had a shallow channel, bordered by a narrow marsh, which wound through a heavy forest. We followed its course for a few miles to avoid cutting a trail through the bush. Every few minutes the dogs turned back, whining as they licked their feet, which had been wet by the water lying on the ice just under the crust of snow; for the water was overflowing the ice and prevented from freezing to any extent by the mineral impurities which it contained. The ice gathered at each crossing on the bottoms of the sleds whence it must be scraped with knife and ax before the dogs could haul the heavy loads in the soft snow. The slush gathered on our moccasins and snow-shoes, and froze in a solid mass in a very few minutes. I broke through the ice with one foot, but as the water did not penetrate to the skin, I continued until we camped for the night, with a cylinder of ice reaching to my knee. The third creek, the Indians said, took its rise near Buffalo Lake. It was but a few feet in width with banks about twenty feet in height.

Our course was toward the south, for two days, along François' trapping trail, where he found a few martens and a fisher in his traps and a dozen hares in snares. He would not sell me the fisher and deliver it to me from the trap, at the price that he would receive at the post after carrying it for a week and skinning and drying the pelt.

The buffaloes were said to be found on the prairies, but these were so small, compared with the wooded area, that I kept asking Henri if we were near the prairies yet, not considering the occasional marshy meadows worthy of the name prairie. The country was monotonously level and covered with innumerable "lakes."

After leaving the trapping trail we had to cut our way through the bush. Henri broke the trail with large hunting snow-shoes which sank several inches in the snow, making a furrow in which the dogs floundered along with their backs on a level with the surface. My snow-shoes were of the smallest size, which made the walking more fatiguing. I used the pushingstick on the level, and hauled on the head of the sled in ascending the steep banks of the ponds. As I tramped along in the 
yielding snow, pushing with all my strength to keep up the circulation of the blood, which was not warmed by the snail-like pace, I thought of how much more slowly the buffaloes of the plains would have been exterminated if those who had killed them in sheer wantonness had been compelled to hunt them as I was hunting the wood buffaloes of the North.

At the end of the fourth day we reached the northern limit of the buffalo range, perhaps fifty miles south of the Great Slave Lake. The next day was spent in search of buffaloes, the dogs being left in camp.

The only result of the day's work, was the opening a trail, six or seven miles in advance, which "set" during the night and formed a hard track for the sleds. When the natives travel in winter, the men keep such a track opened a day's march ahead of the women, who follow with the sleds, set up the deerskin lodge at nightfall, and cut wood for the camp-fire. In this way the moose and caribou along the route are secured by the hunters, and not driven away by the noisy company in charge of the sleds, and then, too, the frozen track makes progress possible for the always overloaded and underfed dogs.

We pushed on the next morning at a rapid pace until we fell in with the soft snow again. Early in the afternoon we entered an extensive grove of pines, Pinus banksiana Lamk., the cyprès of the métis. The trees were the largest that $I$ saw in th: country, of this species. ${ }^{1}$ We camped late and were until ro A. M. the next day, in reaching the prairie, at the farther side of the banksian pines. There another day was spent in fruitless search for signs of the buffaloes. We had just enough provision left for the return trip. François said that it was four days' travel to the next prairie, and he did not know the way. I had no alternative but to turn back. The snowstorm, which prevailed during our stay at the last camp, filled our track and made the hauling as heavy as during the outward journey. One of my dogs had injured his shoulder on the way to Providence, and I had to turn him out of the harness and help the others with the pushing-stick.

We started down the Little Buffalo River late on the thirteenth day, against a strong wind. The thermometers at the

II found groves of fair-sized banksian pine as far north as the Sab-met'ie-kfwa Hills, at least fifty miles north of Rae. 
post registered forty-three degrees below zero at that time. Henri left us at a brisk run, yet his nose and cheeks were frozen before he reached François' house. I could only face the wind for a few minutes at a time, but by devoting my whole attention to it I escaped with slight nips where the ice formed in my beard. François' cheeks were frozen; when in sight of his cabin, he bolted for the fire and left his dogs to be attended to by his wife. Imagine my feelings on finding that the fish had been stolen which my dogs so greatly needed, or my own satisfaction in seeing them whip the band of about twenty giddés at feeding time, and recover their own.

I reached the post the next day and learned that the returned packet men had heard that two buffaloes had been killed by the Smith Indians in the fall, and that the main herd had just passed in our direction. As François killed buffaloes nearly every year, the people at the post were confident that we would find them. I had not time to make a second attempt from Resolution or Smith, as the time was near at hand when I must prepare for the musk-ox hunt.

During my absence from the post, a trader had arrived from Willow River, twenty miles north of Rae, accompanied by Chillouis, one of the numerous Laferté family. Chillouis had not been a very successful guide, as they had lost their way and spent a night on the open lake without fire or food. He was cross-eyed and said to be unable "to follow a beated track."

The trader was ready to return and I was glad of an opportunity to accompany him, as I had expected to cross the lake alone. We started on the $24^{\text {th }}$ of January and slept that night in a solitary cabin which an enterprising métis had built near l'Isle de Pierre. We were awakened two or three times by the arrival of small parties of Yellow Knives, who were on the way to the outlying camps. The single room was soon filled with men who, after disposing of several kettles of tea, threw themselves down upon the floor with a heap of dog harness, an extra capote, or the floor alone for a pillow. Each man wrapped in a single blanket, pulled close over the head, stretched his bare feet toward the fireplace, above which the moccasins and ragged foot-wrappings were drying. Notwithstanding the vitiated atmosphere, caused by thirty persons occupying an almost air-tight room, for several hours, I rested 
very comfortably upon that cabin floor and felt little inclined to leave its comparative comfort at $4 \mathrm{~A}$. M. to harness my shivering team in the biting cold of an arctic night and start before daybreak across the Grand Traverse.

The Indians usually cross at night, directing their course by the stars. They dread the cold winds which blow during the day and fill the air with drifting snow until all landmarks are obscured.

Until we reached the mainland north of the lake, we had to dig driftwood for fuel out of the deep snow. We followed the canoe route, with which I had become painfully familiar the preceding summer, As we were plodding along one evening among the islands, my dogs suddenly caught the scent of a band of caribou which was somewhere to windward on the mainland. They had been hauling as if quite exhausted, but that scarcely perceptible breath of air was sufficient to start them at full speed toward the familiar game.

We reached Rae late on the sixth day, though we had to rise at $3 \mathrm{~A}$. M. each morning to make the trip in the appointed time. I suffered from the mal de racquette the last day which, fortunately, had not before troubled me on the whole six hundred and fifty-mile journey; I had been absent two months from $\mathrm{Rae}$, had pushed the sled most of that distance, and had not even seen a buffalo track for my pains.

The prospects for a successful musk-ox hunt, which was the next and the chief undertaking of the expedition, were not promising, so that my spirits were at the lowest ebb during the month of February, I894, which I spent in the cold and lonely cabin at Rae.

During the month Mr. Hodgson and I maintained a "trapping track," or rather, a line of poisoned baits, thirty miles in length. The Dog Ribs were so afraid of strychnine that they would not even touch an animal killed by it. They know that it is very bad medicine indeed, for did not Kwatse die in the springtime from using the water of the Great Slave Lake a few miles from where a bait had been left in the winter's snow? The Loucheux of the Lower Mackenzie are not so timid, they use strychnine for baits without fear. Nearly every clerk sets a few baits each winter, which usually succeed in killing the favorite dog of the post, a red or cross fox, or very rarely a silver fox. 
I occupied the few hours of daylight, at that season in cutting firewood and in writing up my journals. I could not work at night as I had neither lamp nor candles. I had great difficulty in keeping the cabin warm enough to prevent the ink from freezing even when I sat beside the fireplace which was kept well filled. Back, writing at the eastern end of the Great Slave Lake in February, I834, had a similar experience: "Ink and paint froze. I made an attempt to finish a sketch by placing the table as near the fire as I could bear the heat; but a scratchy mark, and small shining particles at the point of the sable, convinced me that it was useless. On one occasion, after washing my face within three feet of the fire, my hair was actually clotted with ice before I could dry it." 1

I several times found that the ice had formed upon my hair in a few seconds so that the comb would not pass through it readily. The fireplace was only large enough to contain a few billets of wood in an upright position. The northern fireplace is never broad or deep. It is designed to throw out as much heat as possible from the small billets of quick-burning pine and spruce wood. It is usually provided with two hooks, one for the tea kettle and the other for the kettle in which meat or fish is boiled. I preferred to cook my own venison, of which I had secured an abundance, and occasionally indulged in a bit of whitefish roasted by suspending it from the rafters above.

Without the daily visits of Mr. Hodgson I should have found the monotony of fort life hard to endure, but his long residence in the Far North had furnished him with a store of experience that enabled him to make the most of the "pleasures of solitude," and had given him a wide acquaintance with the natives and the peculiar cult of the Company's people. Stalwart of frame-standing six feet three inches in height-he was respected by the natives as a man not to be trifled with. The prestige of "The Honorable, the Hudson's Bay" has been in no small degree acquired through the personal valor of its representatives whom I have seen attacked by rowdy natives. (Crees) "out of pure cussedness," though the Northern Indian as a rule is a very timid creature.

${ }^{1}$ Narrative of a Fourney to the Shore of the Arctic Sea, p. 173. 
Each evening the watchman's whistle at the storehouse called some member of the families of the two engaged servants, to receive the rations for the following day. These were called their "pret," and "giving out pret" was the principal event of the day. At some of the posts the servants are summoned for rations by a bell or by a gong, but whatever the signal it is promptly obeyed. A laborer's ration is four fresh fish a day, or four pounds of half-dry, or three pounds of dried caribou meat; one and one-half pounds of tea, and two pounds of negro-head tobacco each month; forty pounds of white pressed sugar, and one hundred pounds of flour each year. The wife gets a half ration and a considerable quantity is usually given for the maintenance of the family, which often contains six or more children, averaging nearly twice the number which the Indian family contains. 


\section{CHAPTER VII}

\section{THE MUSK-OX HUNT}

TOWARD the end of February the Indians gathered in bands $I$ along the edge of the Barren Ground, where they killed caribou in preparation for the musk-ox hunt. A considerable portion of the Yellow Knife and Dog Rib tribes depend entirely on the sale of musk-ox robes to obtain credit at the Company's stores, from which they must buy tea, tobacco, ammunition, etc. Since they had given up the fall hunt, owing to the severity of the season, it became the more necessary that they should succeed in the spring. They were unwilling to run the risk of admitting a white man to the great hunting ground, which is peculiarly their own. Although they looked upon any white man not connected with the Company as lawful prey, who was to pay exorbitant prices for their services, because "he is rich and we are poor," their superstition was stronger than their cupidity. Naohmby sent a message to the effect that I might come to his camp if I wished. True, he had promised to take me to the musk-ox, but he and his followers were starving and it was doubtful if they could kill any caribou for the hunt. This was not encouraging, and as I knew that Naohmby really followed the longest route to the Barren Ground, reaching it at a point northeast of the Great Bear Lake, I gave up the plan of accompanying him and determined to pounce upon the first band of Dog Ribs which made its appearance at Rae.

On the 4th of March I told a party of four, who had come to the fort for ammunition for the hunt, that I was going with them whether they wanted me to do so or not. With the aid of the fort interpreter we discussed the matter until midnight. Johnnie Cohoyla, a petty chief, was leader of the party. $\mathrm{He}$ had been engaged by the Company in his younger days as a boatman, when he had acquired a limited vocabulary of Red 


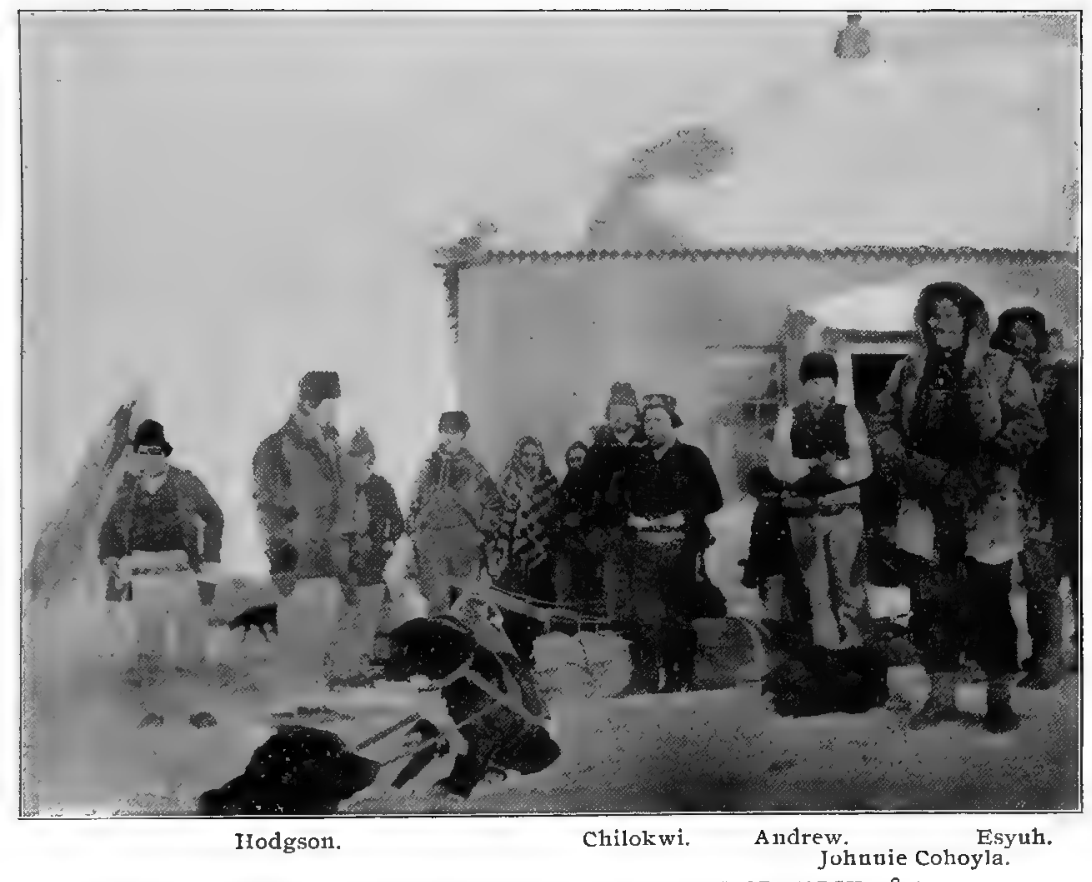

HODGSON'S OUTFIT LEAVING RAE ON THE FOURTh OF MARCH, I894. 

River French. He finally consented to "look after me," which meant to look at me doing my own work, and to cook for meif I purchased meat for him and his family, which became surprisingly large in a short time. In return I agreed to pay two skins, or one dollar a day, and supply tea for our party during the trip.

We started late on the 5 th for the Indian camps at the edge of the timber. I was not in a cheerful mood as I hitched in my dogs for the long journey which, the Dog Ribs emphatically declared, would kill me, as they, accustomed to such a life, "found it hard." I would have to walk or run on snowshoes the entire distance, and not lie in a portable bed or cariole as do most travelers in the interior of the Far North, while some native driver attends to the team. I would not hear an English word for two months, and the antagonism of the unwilling Indians must prove a source of constant annoyance.

My outfit consisted of a 45-90 Winchester and ammunition, fifteen pounds of dried caribou meat, eighteen pounds of frozen bread, several pounds of tea, and a few ounces of salt. My bedding consisted of a single four-point blanket sewed to a light caribouskin robe.

Johnnie tried to "plant" me on the hundred and fifty-mile trip to the camps. He would have walked that distance in two days, but his dogs were not equal to the task, and though they were beaten until their heads were bruised and bleeding, they could not reach our destination in less than three days. My ankles troubled me with the torturing mal de racquette, which made me very glad to see the dirty, smoke-begrimed lodges with their swarm of dogs and half-naked children. The whole camp was soon wrangling over my last pinch of salt. I was dependent upon my rifle or the Indians for meat, ${ }^{1}$ which with tea made up the bill of fare for the next two months.

The Dog Ribs were not ready for the great musk-ox hunt. They must first make new snow-shoes, sled lines, and moccasins; caribou must be killed and pounded meat and grease prepared.

We moved our camps twice during the next three weeks, and

1 I experienced considerable difficulty in obtaining the names of those who sold me meat. I had no goods with me, so that it was necessary to keep an account"of all purchases. It was only by inquiring of others that I could learn the name of the person concerned. 
thus interrupted the drearily monotonous rub-dub of the noisy drums, to the beating of which the men sat and gambled from early morning until midnight. They were not willing to venture as yet upon the bleak desert of snow, known to them as the Tĕch-in hoo-le-_-"No-wood" country. At last, however, it was finally decided that we should start after the Easter festivities were concluded.

On Easter Sunday we all gathered at an early hour in the chief's lodge for prayers. The men, their hair and faces freshly greased, were the first to arrive and took their places in a semicircle round the fire opposite the entrance. The women seated themselves in a group near the door flap. "Jimmie the Chief" occupied the post of honor at one side, on his right sat his wife, beyond whom were the other women and the children. On his left was Johnnie Cohoyla, the choir leader, and I the guest of the band; next came the older men in order of rank. We all sat crosslegged upon blankets, spread on the floor of spruce boughs. The women brought the family tinware, a plate and cup for each person, wrapped with the hymn books in a piece of coffee sacking which afterward served as a table cloth. Over the fire hung a ten-gallon kettle of boiling meat, while beside it stood other copper kettles containing several gallons of tea for the dinner, which always followed the Sunday service. When the prayers were concluded, the chief's son took the meat from the kettle, giving the choicest pieces to the leaders and the poorest to the women. We usually had a few fresh caribou tongues each Sunday, but on this occasion there was one for each person, and a ball of freshly made pemmican. The meat was served in tin or birch pans; those portioning it out took some time to make up their minds about where to put certain pieces and changed them from one plate to another several times. Grace was repeated in concert; then the chief threw a tongue and a small ball of pemmican into the fire and the feast began; as the meat was cut from the bones they were cracked for the marrow.

Two hours later we had a second meal of boiled meat, and as I had given them a little flour before leaving the post, a kettle full of the much-prized rubaboo was also prepared. This was made by cutting up a quantity of back-fat into small cubes and boiling, stirring in flour to thicken it. After this was dis- 
posed of, the women returned to the other lodges-within a few yards of each other-to dress skins and perform other disagreeable labor that had been reserved for an occasion when the lord and master was not at home. The men spent the afternoon in singing hymns, translated into the Dog Rib tongue by the missionaries, and in chanting the old songs of their own composition.

On the evening of the 28 th my dogs were not to be found at feeding time. "Ti-kă ils mangeaient vos chiens, as'soir," said Johnnie. "Yăz-zı̆ ti-kă thlon" said the others. "The wolves will eat your dogs to-night." "Yes, the wolves are very numerous." Without the dogs I could do nothing; missing this opportunity to secure musk-ox, I must remain another year in the country or go back to Iowa without these, the most difficult to obtain of American mammals. After a long search the next morning, I found two of them feeding upon the remains of a caribou six miles from camp, and by 3 P. M., just as I was concluding arrangements to buy two miserable little giddés, the other two dogs made their appearance. I felt that a year of my life had been restored. An hour later we started on the grand hunt, in which only the best men engaged; the women and children, of course, remained at the camps in the woods. There were eleven Indians in the party, with two lodges-Johnnie in charge of mine with three other Indians.

We occupied the greater part of the second day in traversing a long narrow lake called Tĕn-ĕn-di-a Tooh. In the afternoon, from the summit of a lofty granite hill, I beheld the Barren Ground for the first time. Behind us lay the rugged hills, their slopes clothed with stunted pines, upon which a bright sun was shining; before us were hills still more precipitous and barren, everywhere strewn with angular blocks of granite-a cold and dreary waste from which a snowstorm was swiftly approaching. Half-acre patches of pines, from one to three feet high, still appeared for a few miles, but our lodge poles were cut that day; these were trimmed down so slender that they would afford little fuel for the return trip; each sled carried four poles, fourteen feet in length. The country was so rough that we only traveled thirty-five miles.

Before starting on the morning of the fourth day, the regular Sunday service was performed, as it was, also, on the two fol- 
lowing Sundays which we spent in the Barren Ground. Notwithstanding the need of haste, and the discomfort of kneeling for an hour, with only a blanket between their knees and the naked rock upon which our lodge was always pitched, the Indians repeated the appointed prayers in concert, and sang two or three hymns responsively, under the leadership of Johnnie Cohoyla. All remained kneeling with their faces toward Rae throughout the service. ${ }^{1}$ The service was marked by a seriousness which I thought resulted more from a superstitious desire to propitiate the wrath of a savage storm god than from a feeling of reverence toward a beneficent Creator.

We encamped that night in a little clump of pines on the Coppermine River. The Dog Ribs called this stream Tson Te. It takes its rise in a large lake, called Ek-a Tooh, which is two days' journey in length. This was the last outlier of the timbered country and we must henceforth carry fuel on our sleds. The largest of the trees reached a height of twenty-five feet, with thick, twisted trunks. We left the Coppermine with our sleds loaded as heavily as the dogs could haul with wood which we had cut and split into billets of convenient size. What a luxury a good oil stove would have been! As we were about to start, Jimmie, who was leader of the band, and by far the most intelligent man among them, after a long look eastward,

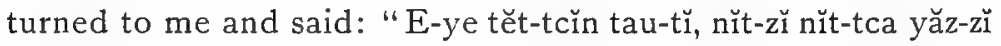
ĕd-să." "This is the woodless country where the blizzards blow and it is always cold." Then drawing his old gray blanket closer about him, and shouldering his double-barreled smoothbore encased in its greasy deerskin gun-coat, he set off at a rapid pace, the seven trains falling into line upon the track of his snow-shoes. We followed the course of a small stream called Kwilond Te for about forty miles, until we reached a lake at least thirty miles in length, called Yăm-bă Tooh.

As we advanced on the seventh day, the hills became more rolling, with gravel and pebbles, but fewer boulders. Wherever the wind had swept the surface clear of snow the reindeer moss, Cladonia rangiferina, and tufts of low grass appeared. Toward evening we passed a few old musk-ox tracks.

1"Les sauvages qui restent loin de l'église, se réunissent le dimanche sur le mont voisin le plus élevé ils s'orientent le mieux possible, se tournent du côté ou ils savent qu'une église se trouve, el chantent des cantiques ou récitent des prières." Farand, Dix-luuit ans chez les Sauvages, p. I98. 
On the ninth day we traversed the largest lake seen north of the Great Slave Lake, which I think must be the Rum Lake of Franklin; it was called Ko-ă-kă-tcai-tì by my companions. Away toward the northern end of the lake, four or five peaks were visible; two of these were lofty cones, standing pure white in their snow mantles; identical in size and shape, with almost perpendicular sides.

We crossed two gravel ridges, trending southeast and northwest, and again encountered the hills of naked granite, strewn with great angular boulders, which necessitated constant watchfulness to prevent our sleds from being broken. These vehicles were the common birch flat sleds of the north, fifteen inches in width and seven feet in length. They soon became grooved from end to end by the sharp points of rocks lying just below the surface of the snow, which plowed across the bottom, ordinarily as smooth as glass, and made the sled much harder for the dogs to haul. Still Jimmie's old gray blanket led the way, straight over the hills, never swerving from a northeast course. Sometimes we would ascend for an hour, and then go pell-mell down a steep incline for two or three hundred feet, holding back our sleds with all our strength, yet landing in the drifts at the bottom, with the sled-dog dragging under and the rest of the team tangled in the harness.

The caribou were now quite abundant, and we had little difficulty in killing enough for men and teams. My dogs were keen hunters and were always ready to dash after the herds of grayhued caribou, which swept over the snowy slopes like the shadows of swift-flying clouds. The only way that I could restrain them was to overturn the sled. In the evening, when they were released from the harness, they would pursue any caribou which might appear near our camp, which caused me considerable anxiety, as the dismal howl of the never-distant wolves gave warning of their certain fate if they left the camp. One of the giddés was lost in this way.

On the tenth day Johnnie, with three other Indians and myself, separated from the others and turned a little more to the northward. We were now in what the Dog Ribs designated the Musk-ox Mountains. After running about ten miles, Esyuh, who was in advance, suddenly turned and began to make frantic gestures. Over the hills, a mile away, appeared a black 
object closely followed by another and another. No need for him to urge us to hasten forward, or to tell us what those huge rolling balls were. "Ět-j'ir-rer! tă-i ět-jir-rer!" Three musk-ox, and a few seconds later the dogs were all released and scattering out over the country, some in pursuit, some on the back track, and other trotting complacently along at their master's heels. They were not well-trained hunters; at sight of the musk-ox even the threatening whip did not prevent them from breaking into howls, and many of them were too spiritless to be of any assistance in stopping the game. We followed as fast as we could run. Then it was that I discovered the advantage of having light clothing, light gun, and little ammunition. The dogs soon overtook the clumsy musk-ox, which turned to defend themselves as from a pack of wolves. They were not held long at a time, but their flight was so hindered that they were overtaken by my companions, who had distanced me, after a run of three miles.

Our lodge was set up that night beside the fallen carcasses, and our teams for once had all they could eat. There were several hundred pounds of meat with fat two inches in thickness on the backs, meat of excellent quality, without the faintest trace of musk perceptible. That from one of the animals was tender and as well flavored as any venison that I ever ate. The others were tough, but the Dog Ribs preferred tough meat to walking a dozen yards to get that of a younger animal. The complexion of our diet was now changed; before we had enjoyed caribou ribs boiled, garnished with handfuls of coarse gray hairs; now we had boiled ribs of musk-ox with hairs of a brownish black.

I awakened next morning with a sense of weight upon my blanket, and my ears were greeted with a rushing roar caused by a northeast gale, which had covered everything inside our lodge, to a depth of a foot or more, with fine flour-like snow. It was impossible to face such a blizzard without freezing in a few minutes. All landmarks were obscured, so that we could not continue upon our course. As we had only wood enough for the time that we expected to be engaged in actual travel, we could have no fire on days like this, when we were compelled to "lay to." We remained in our blankets until midday, when a kettle of meat was (half) boiled and we turned in again. 



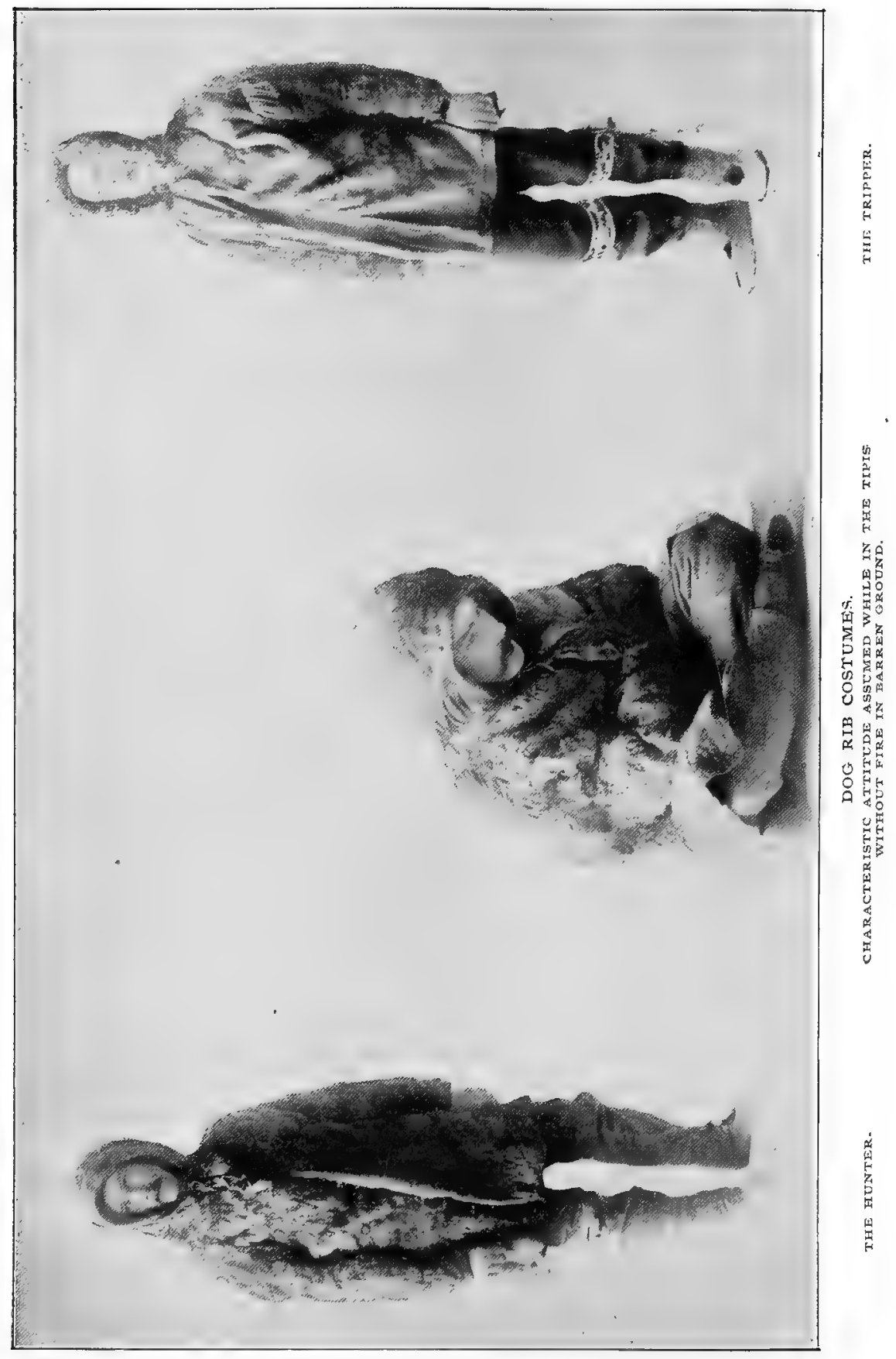


In the evening a fire about the size of a cigar-box was kept up long enough to boil a kettle of tea, one cup for each man; we always wanted four! No meat was cooked, for our appetites were soon satisfied with the large sticks of white frozen marrow from the long bones of the musk-ox.

We usually drank snow water, as soon as snow could be melted, after the camp fire was started. Each individual carried a tin plate on which a block of snow was placed and inclined toward the fire. As the lower side became saturated, we drank the water as from a soggy snowball, and so avoided the cinders and hairs which quickly covered everything about the diminutive fire. Before leaving the woods we had melted snow by fixing large blocks on the ends of poles before the long camp fire; a steady stream soon trickled from the lower end which was trimmed to a point by a few strokes of a knife.

Throughout the trip we washed our hands and faces daily by melting water in tin plates and squirting it, à la Chinese laundryman, upon our hands. The whole party possessed two pieces of soap and one towel. A Dog Rib towel is never washed, its owner's face is often greased and the color of the towel is affected accordingly.

Throughout the following day the storm continued with increased severity, and we were forced to lie in the snow another twenty-four hours.

My dogs never came inside the lodge at night, but coiled themselves up in the lee of the lodge, where the snow soon drifted over them, giving warmth and shelter. The twelve Indian curs came inside as soon as the last man rolled up in his blanket at night. At first they spent a few minutes fighting over the bones about the fireplace, then they rummaged through everything that was not firmly lashed down. As a dog walked over a prostrate form the muffled "marche!" or "m'nitla!" would quiet them for an instant, when their snarling and snapping would break out anew, until some of us would pick up a billet of wood and "pacify them." After we had once fallen into the sleep of exhaustion we were seldom awakened by their fighting over us. In the morning I usually found two or three giddes coiled up in the snow upon my blanket; the heat of their bodies melted the snow, which froze as soon as they left it and made my scanty bedding hard and stiff. 
After sixty hours of such resting we were quite ready to move on, as the thirteenth day dawned bright and clear. Early in the day we caught sight of a band of forty musk-ox already in flight a couple of miles distant. We chased them six miles, but only one of our party reached them, Wisho, who killed four. We were very much fatigued from our long run, and covered with perspiration which froze on our outer garments, as we walked back with the dogs to bring up the sleds. It was after nightfall before we set up the lodge and cold, tired and hungry, sat shivering around a column of smoke over which hung a kettle containing both meat and drink; for our supply of tea was exhausted and we had to quench our thirst with the greasy bouillon or "tewoh" in which the meat was boiled.

The temperature was falling rapidly, giving us some concern about Johnnie Cohoyla, who had not returned. The next morning I was awakened by the monotonous wailing of his brother, Esyuh, who was chanting the virtues of the lost reprobate, and entreating the fates in general, and the North Wind in particular, to spare him.

"Tǐn-nĕh hu-le"-_a man is lost!"

The Dog Ribs repeated the phrase with significant glances at me, as if this "Mo-lă" accompanying them had offended the Great Spirit, so that he had wreaked his vengeance upon the man who had allowed me to enter the Dog Rib hunting ground. A terrific gale prevented us from searching for the lost man; we could only spend the day in our blankets while the snow drifted in and over all. That was one of the most miserable days I ever spent. I had tried twice to run with the Indians, and failed to reach the musk-ox, and there seemed to be no immediate prospect of my getting any. The musk-ox were not numerous they said, and our wood might fail before we secured any more. Johnnie must have perished, as no human being could live through a night of such storm without protection, and it was thirty-six hours before we could search for him. We were shivering in our blankets, even the Indians saying, "Ed-să, yaz-ž̀ ed-să"-"it is cold, very cold."

The next morning proved to be calm, and we set off in search of Johnnie. I had as great difficulty to keep my cheeks from freezing as at any time during the winter, though there was scarcely any wind blowing. 
After running about ten miles, I was recalled by the signaling of another searcher. Johnnie had been found by his brother, safely and snugly rolled up in a couple of musk-ox skins which he had secured, where he had been warmer than if in the lodge, and with plenty of frozen marrow to eat he had been quite comfortable.

On the sixteenth day we continued the journey northward. With the field glass I discovered a band of fourteen musk-ox on the summit of a high hill, so far away that it was impossible to distinguish them from the surrounding boulders with the unaided eye. In a couple of hours we were within half a mile of them, and released the dogs, which soon disappeared over an intervening ridge. My companions had concluded, from the way that I had run, or failed to run, on the two previous occasions, that I could not run very far, and that their best plan to keep me from bringing a magazine gun into competition with their muzzle-loaders, was to give the musk-ox time to get far enough away so that they could "plant" me in the race. I had prepared for this occasion by taking off some of my clothing, and only carrying the ammunition actually required, so that when they did begin to run at a swift pace my snow-shoes clanked close beside them.

We soon came upon eleven of the musk-ox standing at bay in two little clusters, hardly lowering their heads at the dogs, whose ardor had been cooled by the statue-like immobility of the noble animals. Their robes were in prime condition, the long hair and heavy erect mane gave them an imposing appearance. To kill them was simple butchery, yet I had no choice but to fire as rapidly as possible and get my share of them, as they were all doomed anyway.

On leaving Rae, Johnnie had agreed to assist me in skinning the game killed; he now found that his own affairs would require all his attention. Esyuh helped me to skin two, while I finished the third by moonlight, freezing my fingers in the operation. $\mathrm{He}$ afterward demanded seventy skins, thirty-five dollars-for his labor.

It was impossible to skin the heads in the darkness. I wrapped the skins around them so that they would not freeze during the night. Another blizzard was raging in the morning, which prevented moving, but enabled me to attend to the 
heads, which had not frozen very much; but the skins around them were stiff and solid, so that it was impossible to fold them up for transportation.

I spent the day sawing the skulls in halves, so that they might be loaded on the sled, sitting beside a little smoke arising from the bones of the musk-ox which contained enough grease to burn, though not very readily. Our fires were started with birch bark, a small roll being carried by each man for that purpose. The pine wood was cut in sticks a foot in length and finely split, then built up in a "log cabin" or a cone. Each man took his turn blowing to keep it alight, as the wood was not dry and the quantity so small that it required constant attention.

We were destined to spend the next day in the blankets, with the clouds of powdery snow settling down through the smokehole of our lodge upon us. We had had but two meals a day since leaving the Coppermine, and when lying storm bound we ate but one. When traveling, although we were voraciously hungry before nightfall, it was thirst which troubled us the most, as we were running most of the time.

Early on the nineteenth day we sighted musk-ox while yet a long distance from them. While ascending a steep hill I was delayed by my sled sinking in the soft snow until the great awkward balls into which the skins were frozen, projecting at the sides, made the load drag heavily. When I reached the top the others were a quarter of a mile in advance, and instead of waiting for me to come up, they had released their dogs and were likely to kill every musk-ox before I could reach them. Johnnie, remembering the havoc which my Winchester was liable to make in his fur returns, thought best to "suspend the rules" of the hunting code, and let me buy of them if I wanted any musk-ox. Without releasing my dogs, which were wildly tugging at their collars, I started forward with little hopes of killing any musk-ox, but in excellent humor for slaughtering a few Dog Ribs. Fortune, however, smiled upon me. Four bulls of the largest size broke away together, without a dog in pursuit, and came within range. This was not so much like butchering them; they were running much faster than I could on snow-shoes and had a chance for their lives. I killed two as they passed me about a hundred yards distant, and wounded the others so that they were bagged after a run of half a mile. I 
had now killed seven musk-ox, and already had as many on my sled as the Hudson's Bay people had told me it was possible to haul. When Johnnie returned from chasing the scattered herd, I stated my plain and unbiassed opinion of him in all the Red River French and Dog Rib that I could command. His deprecatory "yăz-zi" changed to a sheepish "ne-zi"--good -when I informed him that I had secured all the robes that I wanted. He refused to carry a skeleton for me at any price, not even a head or half a split skull would he carry, though I gave him two robes for carrying back the lodge.

The next day was spent in camp; the others were engaged in skinning the animals killed, and in boiling bones for grease to eat on the return trip. I thus had an opportunity to prepare the two skulls for transportation.

On the twenty-first day of the hunt we started homewardthe turning point of the expedition. We were all heavily loaded with the loose, bulky skins. The sleds were frequently overturned, and if our dogs had not been in unusually good condition would never have been brought out at all. My load extended over both ends of the sled, and was nearly as high as my shoulders. With the four lodge-poles on the top, it was no easy matter to keep everything lashed firmly.

On the twenty-third day a blinding snowstorm prevented moving before midday, when we pushed on through the soft snow without meat for ourselves or the dogs. On the return trip we only secured five caribou, which was less than half rations for five men and sixteen dogs.

We were now burning our lodge-poles for fuel; on the night of the twenty-fifth day the lodge was set up for the last time, with two poles only, and with our sled lines, made fast to the circle of sleds, which were always enclosed, gave sufficient support. We started at 6 A. M., determined to reach the Coppermine, some fifty miles distant, before camping. In the afternoon we came upon a lodge-pole, standing beside a sled track which we had followed all day, upon which a line written in the syllabic characters informed us that Jimmie's party was to reach the woods that evening also.

At half past ten, after sixteen and a half hours of continuous traveling, we reached the little grove of pines, which seemed more welcome than any harbor to the storm-tossed sailor. We 
were all too much fatigued to cut much brush, and fell asleep in a little hole scooped in the snow, before a few logs which made such an uncomfortably hot fire that we did not enjoy it as we had anticipated. But we would no longer have to sleep upon snow or flat rocks, we would not have to sleep with our moccasins and frozen blanket footings next our bodies to dry them, and at noonday we could have tewoh to quench our thirst.

After five hours' rest we were awakened by Jimmie, who reminded us that there was nothing to eat, and that we must push rapidly on. My load weighed over five hundred pounds, and the dogs were getting pitifully weak. I pushed on the sled and carried a load on my back to assist them. We were three days in reaching the camps. We only rested five hours at night and then hurried on again, as the teams were failing rapidly for want of food. On the twenty-eighth day the first signs of a thaw appeared; the snow softened just enough to cause it to stick to our snow-shoes, so that it made them heavy to carry, and, worse still, lumps of ice would accumulate every few minutes which soon blistered the bottoms of our feet over the entire surface.

On the last two days before reaching the camps the heavy snow-shoes caused the mal de racquette to reappear, which made it simply torture to move; yet we were now in the woods, where the soft snow required heavier work in the management of the sleds.

At two in the afternoon of the twenty-ninth day we reached the vicinity of the camping place from which we had started, and fired several rounds to announce our arrival. ${ }^{1} \mathrm{~A}$ few minutes later we dashed into-a deserted camp. The lodges were gone, the snow had drifted over their sites. Their skeleton poles offered a dreary welcome to us as, tired, hungry, and disappointed, we turned away in no pleasant humor to follow the track along which a line of slanting poles indicated the direction of departure. We were upon an old, hard track from which the sled frequently overturned into the soft snow on

1 The Indians about the Great Slave Lake still follow the custom of firing their guns at the time of arrival at, or at departure from, the trading stations, or their own larger camps as in this instance. I witnessed this ceremony several times at both Rae and Resolution. Compare Mackenzie, "We were saluted at our departure with some vollies of small arms, which we returned." Fournal, p. I8. 
either side, and my dogs were about giving up altogether. A great deal more powder was burned as we approached the camps, three hours later. As I passed one of the first lodges my sled swayed off the track and caught against a tree, much to the amusement of a' couple of young women who, after watching my attempts to right it, remarked, "Yaz-zì Mo-lă nät-sŭth-lï"-_" the white man is weak, indeed." One of them grasped the sled line to show me how to straighten up a load, and tugged and hauled and tugged again without producing the slightest effect. I am afraid that I laughed very ungallantly as the discomfited maiden fled to the shelter of the lodge. Mrs. Jimmie came to me with a very cordial greeting, exclaiming, "Merci! Merci-tco! Ne-zi ét-jür-rĕr-kă!"-_"Thanks, big thanks, for the good musk-ox hunt!" evidently ascribing our success, in a measure, to my presence. We had been absent twenty-eight days from the camps, twenty-two of which were spent beyond the Coppermine River.

There was very little meat in the lodges and the caribou were moving out into the Barren Ground, so that the Indians must lead a more than usually precarious existence for the next two months until they could follow the caribou by water. For three days they were quite content to lie about the camp, feasting upon the store which still remained of dried meat and grease. They would not sell me any of this, though I needed a supply very much for my journey down the Mackenzie.

I had left a small bag of articles in Johnnie's lodge, during the hunt, which they had opened and discovered that it contained a few ounces of compressed tea that I had reserved for the trip to Rae. They did not appropriate the tea, but the next day after our return they began to clamor for it to make tea for a Sunday feast. I knew that they had several pounds of tea, and I had no intention of throwing away the only comfort possible on what I knew would be a trying journey. First Johnnie, and then then the whole band, came to me with smiles, whines, and finally threats. Johnnie boiled a large kettle of water and placed it before me with an insolent demand for "lee tea." I could contain myself no longer. I felt dependent on them to guide me to the post, which it was utterly impossible for me to reach, through two hundred miles of trackless forest with my load of musk-ox, without their assistance; but 
three days of nagging, culminating in that defiant act, finally overcame my power of self-restraint and I turned loose my wrath upon Mr. Cohoyla with a vehemence which seemed to have a salutary effect. I believe that I grew rather eloquent in the jargon of Dog Rib and Red River French which I employed, pieced out with gestures and emphatic, though to them unintelligible, English.

On the thirtieth day of April, I started for Rae accompanied by three Indians with two empty sleds, on which they refused to haul any of my load, though I offered to pay them well; they were still sulky about the tea. Johnnie came to me before I started with a long list of the goods from the store that he wished as a reward for his fidelity! Jimmie invited me to a dinner of tongues and pemmican and seemed anxious to atone for the insolence of the others. I could understand him much better when conversing, with the few words of his language which I had acquired, assisted by gestures, than I could Johnnie with the aid of his French.

We followed the course of the Jackfish River toward the southwest, crossing short portages from lake to lake. The descent at the portages was abrupt and of considerable extent; we must have been many hundred feet above the Great Slave Lake when we started. The abundance of stumps at the camping places showed that we were following one of the great highways, which is used in both summer and winter in traveling to and from the Barren Ground.

I had nothing but dried meat to eat or to feed my dogs. I was truly ashamed to offer that leathery "scrap" to my team which was straining to the utmost limit of its strength. Though they could gulp down a three-pound frozen fish in a few seconds, my dogs could scarcely eat the dried meat which I cut in small pieces for them.

On the fourth day it became much warmer and the crust frequently gave way beneath the dogs, the sled, and my own snow-shoes. The sled sometimes rolled over in the soft snow a dozen times in traveling a hundred yards. Strange to say, the mal de racquette, which had made me miserable for the preceding week, left me that morning or I should not have been able to travel all. The Indians urged me to employ their remedy for this painful malady, which I did to please them. 
They held a split stick over the affected ankle while a second stick was turned through one revolution, tightly squeezed in the split. They insisted that I should do this for myself which seemed to afford them great satisfaction, especially as the pain left me soon afterward.

On the fifth day we traveled eighteen hours and reached Rae after one of the hardest day's travel of the whole trip. The snow was rapidly melting, enabling us to find drinking water on the ice beneath the snow crust, through which we frequently broke with our snow-shoes.

As my weary dogs crept over the hill into Rae and dragged the load of five complete skins and heads of musk-ox in front of the door which they had left two months before, they sank down utterly worn out. I lifted them out of the harness and prepared my evening meal with slow and exhausted movements, but sustained by a devout feeling of thankfulness that the journey had been successful.

I had worn goggles constantly to avoid snow-blindness, which causes great suffering among those natives who are not so fortunate as to have protection of some sort for their eyes. Wooden protectors, such as are used by the Eskimos, are unknown by the Dog Ribs. Goggles of smoked, blue, or green glass are in demand, though enough for all have never been brought in by the traders. The smoked glass is the best. Veiling is used when glasses are not to be had. I never heard of a Dog Rib blackening his face to prevent snow-blindness. While in the Winnipeg region I saw a pair of "horsehair goggles," which were superior to any other protectors for the eyes that I ever met with. They were made entirely of hair, woven in a loose mesh, convex over the eyes. I should advise anyone intending to travel in the North to provide himself with them, in preference to glass which is coated with frost at every change of temperature, is always cold to the face and liable to be broken.

From the experience gained during that eight hundred-mile trip, and from conversation with Mr. Mackinlay, at Resolution, I am satisfied that Resolution is a much better post from which to hunt musk-ox than Rae. The Dog Ribs now trade at both stations, and Beniah, one of the most enterprising of that tribe, for the last five years has killed musk-ox within two days' 
travel of the woods at the east end of the lake, beyond the territory occupied by the Yellow Knives. ${ }^{1}$ The distance to be traveled from Rae becomes greater each year, and the post itself is not now so well supplied with provisions or with goods with which to hire native assistants.

My advice to sportsmen is to keep out of the musk-ox country, if life and health are valued. To be sure there is a satisfaction in overcoming the obstacles which must be encountered before the musk-ox are reached, but at the end, when you are within rifle-shot of the long-sought game, you find after all that it is a cruel butchery; you do not feel the triumphant exhilaration which results from successfully pursuing the noble moose or elk; in fact you can duplicate the sensation felt on such an occasion, at far less expense and less hardship, by hiring a pack of hungry curs for an afternoon, and turning them into your neighbor's sheep pasture. When they have rounded up the flock, you can take your stand at a safe distance and shoot down the sheep! The musk-ox is not a "sporty" animal.

During my absence the incoming packet had arrived, with but one letter for me. Fortunately this one was from Professor Nutting, who approved of a plan which I had formed for the summer's campaign and sent out by the December mails.

I had intended to remain another winter in the country if I failed to get the musk-ox, and then to return by the route traversed in going North. As the hunt had been successful I was ready to return, after $I$ had employed my time to the best advantage, in collecting ornithological specimens during the short summer.

Mr. Hodgson gave such glowing accounts of the abundance of game, birds, and other desirable specimens near the Arctic coast that I wished to visit the region even though I would not have time to make a large collection.

1 Compare Pike, Barren Ground, p. 274, who wrote before Beniah entered this new territory. "I am not quite sure that Fort Resolution is the best point to start from. Fort Rae, on the north arm of the Great Slave Lake, lies nearer the Barren Ground, and the Dog Ribs are said to be more amenable to reason than the Yellow Knives, while the distance to travel through a woodless country is shorter." 


\section{CHAPTER VIII}

\section{DOWN THE MACKENZIE}

A FEW travelers have descended the Mackenzie to McPherson, crossed the mountains by the Hudson's Bay Company's trail to Fort Yukon, and then descended the Yukon River to St. Michaels. No one had ever descended the Mackenzie to its mouth, and succeeded in reaching civilization around Alaska. I learned that American whalers were wintering at Herschel Island, near the mouth of the Mackenzie, and that some of the vessels would return to San Francisco at the end of the season. I could not profitably occupy the summer at Rae, nor would I have time to descend the Mackenzie and return home by open water over the same route. It seemed possible to reach the whalers and accompany them to San Francisco. The time and money needed would be about equal to that spent in returning by way of Edmonton, but I would have the advantage of exploring two thousand miles of new territory, which decided me to make the attempt.

The "Wrigley" is hauled ashore for the winter near Providence whence she leaves, as soon as the river opens, for Good Hope. If I could reach Providence before the steamer was launched and started on her northward trip, I could save a month's time in "descending the river, and might reach Herschel Island before the whalers left their winter quarters.

It was reported that a whaleboat would be sent up to McPherson to engage Indians for the summer's whaling. If I did did not meet this it was very uncertain whether or not I could hire Indians to accompany me from the last Hudson's Bay Company's post to the island. The musk-ox skins would require daily attention in drying for several weeks, but $\mathrm{Mr}$. Hodgson volunteered to care for them until they could be sent out by the "Wrigley," two months later. Under his direction 
they were dried and carefully packed. He had secured a year's furlough and was "going out to Red River," so that he accompanied the collection as far as Edmonton. He also packed some specimens which I had left at Smith, and looked after the cases, while ascending the Athabasca, where accidents frequently occur in the rapids. With the collection off my hands, I felt free to make the attempt to reach the whalers, and if I failed and had to spend the next winter snow-shoeing my way to Edmonton, I could stop at Fort Smith and try again for buffaloes.

During the five days which I spent at the post, I was busily occupied in caring for the large skins, and in packing the remainder of the collection. It was too late in the season to travel over the portage trail to Providence, which I had followed in the autumn, as the snow was rapidly melting in the bush. I intended, therefore, to follow the lake shore to the Big Island fishery and there to hire a canoe of the métis or Indians in which to descend the Mackenzie to Providence, forty miles below the island. I was assured that the river would be breaking up, but that I need not be delayed, as there would certainly be a number of canoes at Big Island and I need anticipate no difficulty in engaging one of them with men to paddle it.

To avoid the expense of an extra train and two men, I traveled alone. I left the post late on the Ioth of May, with a heavy load, which included fish for the dogs for five nights, as I expected to reach Big Island in six days.

After two hours' traveling, the snow had thawed so that the dogs could not haul at all, and I was forced to lie by until a crust had formed in the evening, when I pushed on all night.

On the IIth I heard the ducks and geese in the small lakes near Trout Rock, where a little open water covered the ice. I camped at $9 \mathrm{~A}$. M. on the IIth, and set out in the evening at 7 , though the snow was still soft. I soon encountered a large crack which I followed for several miles before I found a safe crossing place. The sun remained below the horizon about six hours, a part of which time it was rather dark to find my way over an unknown and trackless route.

Hauling dogs, however well trained they may be, are accustomed to follow either a beaten track or a man running before them. A team, driven alone, that seems to be exhausted and which the severest whipping will not force any farther, will 
start off at a brisk trot and strain at their collars to keep up if someone runs before. I had to direct mine with the whip and voice alone. They were too heavily loaded to keep moving if I went before them.

In starting out in the evening, I had to wade through a broad strip of slush, lying just outside the heavy shore drifts. The water passed through my moccasins as easily as through a blotter; these and the thick foot wrappings soon froze stiff, as it became colder, making them heavy and anything but warm. I broke through the crust into the water standing on the ice too often to keep them dry by changing. I found it necessary to wear more on my feet than in midwinter to avoid blistering them. The snow-shoes were kept continually wet and wore rapidly away upon the sharp needles of the crust, so that I had to renew the foot-lacing daily. On the 12 th I camped upon a little patch of bare sand, the first camp not made in the snow since November. That day the ring-billed gulls were seen, though there was as yet no open water except upon the surface of the ice.

I lost some time at the Big Slavey Point, in skirting two deep bays, looking for a passage behind the little group of four islands, which I found later to lie so far off shore that no mistake need have been made.

On the I $4^{\text {th }}$ a dense fog compelled me to follow the shore of the broad bay west of the point, where I could have saved several miles by a traverse.

During the night of the $15^{\text {th }}$ a rain fell which prevented the formation of a crust and made the traveling very slow and fatiguing. I.fed the dogs the last fish that night, and, instead of sleeping next day, pushed on until after midnight in the hope of reaching the Big Island fishery. I started in the evening across a traverse, of perhaps ten miles, to the outlet of the lake where the dark line of trees was barely visible on the shores of the bay, which I was crossing, lay below the northern horizon. There were no landmarks whatever to guide me to the fishery, and, to add to the difficulty, the low strip of timber became distorted by mirage until it seemed to be a chain of distant mountains, then three lines of coast appeared one above another. These merged into one again, still slowly shifting until obscured by the darkness. The point which I had left 
soon began to dance in an uncanny fashion, so that I had to direct my course by the stars. The snow was deep and soft and the dogs were nearly worn out, so that it was very late when I approached the shore closely enough to see the dark looming of spruce trees a few hundred yards in advance. A large crack, with open water extending across my course. caused delay; after passing this on a frail bridge, I encountered ice which had several inches of water standing upon it. There was just light enough to enable me to distinguish here and there a black hole in which there appeared to be no bottom. I had been warned to look for rotten ice at the head of the river, and as the black patches appeared to be larger and closer together as I advanced, I was compelled to turn back and wait until daylight. Dragging the sled back to solid ice, I laid down upon it and slept for three hours. When I awoke the sun was shining upon $\mathrm{my}$ face and I could realize the danger which I had been in. I had gone a half mile too far to the northward. The ice was full of holes and I could not get ashore without wading and picking my way very carefully. As I ascended the bank I noticed a few sticks standing in circles here and there in the river ice, and the ridges, which had once been furrows made by the sleds passing to and from the nets, showed that someone had wintered near by. A few wooden crosses, enclosed by a dilapidated picket fence, stood at the entrance of the river. The timber had evidently been cleared away, and the graves and fish stages indicated the proximity of a settlement, still no dogs greeted my approach; the waterfowl were making discordant outcries from every pool, as if the place were deserted, and so it proved to be when, a minute later, I came in sight of two cabins surrounded by such extensive staging as to leave no doubt but that they were the property of the Company.

Releasing the dogs from the harness, I spread the contents of the sled upon the staging to dry, and, after drinking a cup of tea, turned in to get some much-needed rest. The next day I heard the occasional report of fire arms across the river, but searched in vain for Indians.

This delay was very annoying, the condition of the river ice was growing rapidly worse, so that I could not travel far on it; if I left my outfit it would prevent my traveling with the 
steamer. I harnessed the team that afternoon, scarcely hoping that they could haul. They had not been able to ascend the bank the day before and had had nothing to eat for three days, during which they had been almost continuously in harness. Much to my surprise they moved off on the ice at a fair pace. The river was flowing in an open channel along the shore, but the greater portion of the ice had not yet broken up, though it was in a very unsafe condition. After traveling about eight miles I reached the lower end of Big Island, but the only land which I could reach with my load was a small island below, which was covered with willows and poplars. I spent the night there and as I could not proceed further with the sled I cached it upon a scaffold.

I was depending upon ducks and grouse for food. I had left Rae with a few pounds of bread and dried meat, beside seven candles of deer's tallow which proved to be a very acceptable addition to the dry meat.

I started next morning toward Providence, carrying a blanket and shot gun, intending to send for the sled as soon as the river opened. After traveling a few miles I met a party of Slavey Indians, who were coming up the river with two sleds, having high runners, made especially for use on overflowed ice. They were the filthiest and most degraded looking Indians that I met in the North. They knew no English, but seemed to understand the few words of the Dog Rib dialect which I could command. They directed me to Jackfish Point, a short distance below, from which they had just come, where a small band of Slaveys were encamped. As usual, they asked for tobacco, and as usual, they thought my tongue was crooked when I told them that I had none, as no Indian would believe, so universal is the habit, that a man did not smoke, especially a master able to carry such weapons as I possessed, and to drive good dogs. I should like to know whether it was a kindly feeling which prompted one of them to call to me to wait, after they had gone some distance, while he brought me a piece of dried meat, which he might have thought that I needed; or whether his generosity was due to a last attempt to get the coveted tobacco. At any rate I gave him some shot and divided the meat among my dogs.

At the low marshy point I found an open channel two to 
three feet in depth and a hundred yards in width. I waded ashore and searched for the camps, which were of such a material and so well hidden by the willows that I might easily have passed without discovering them.

Instead of the well-made caribouskin lodges of the Dog Ribs, they had nothing but rude enclosures covered with grass and reeds. Two families had smaller canvas tents, adjoining their lodges, which afforded them shelter from the rain.

They were surprised to see a white man traveling alone and soon gathered in the chief's lodge to drink tea. They understood neither French nor English, and we talked and gesticulated for two hours before they seemed to understand that I desired their assistance. They said that the ice was unsafe, the open water did not extend to the post, and to travel through the bush was impossible. They were living on jackfish, which they killed with sharpened poles. I fed the dogs several fish, but found to my surprise that they would not eat more than one fresh jackfish each. After my fourth meal of boiled jackfish, without salt, I, also, had little appetite for them. The next morning I told the Indians that I was going to the post over the ice, and that I would give them no more tea; this decided the matter and two of them volunteered to accompany me. We brought the sled to the camp, loaded everything but the dogs in a canoe and pu shed off.

My dogs were to be fed and brought down to Providence as soon as the river opened. It was not without regret that I parted from that faithful team, which had hauled from the time when the first snow fell until after the last bank had disappeared on the land. They had traveled over twenty-two hundred miles, through trackless bush and dismal barrens. With aching limbs and bleeding feet they had toiled on, their only reward being the half-putrid fish of which I was often unable to give them a full ration. Many a time they had been beaten into the snow when exhausted and hungry. Many a time they had been harnessed in the morning, too weak and stiff to start the heavy load, only answering the cutting whip with their piteous whine. Nudjuk, Treff, Major, and Corbeau, we have hunted, eaten, and slept together for the last time.

We camped that night upon a gravel bar across which the geese and ducks were continually passing, so that we easily killed enough for our use. 



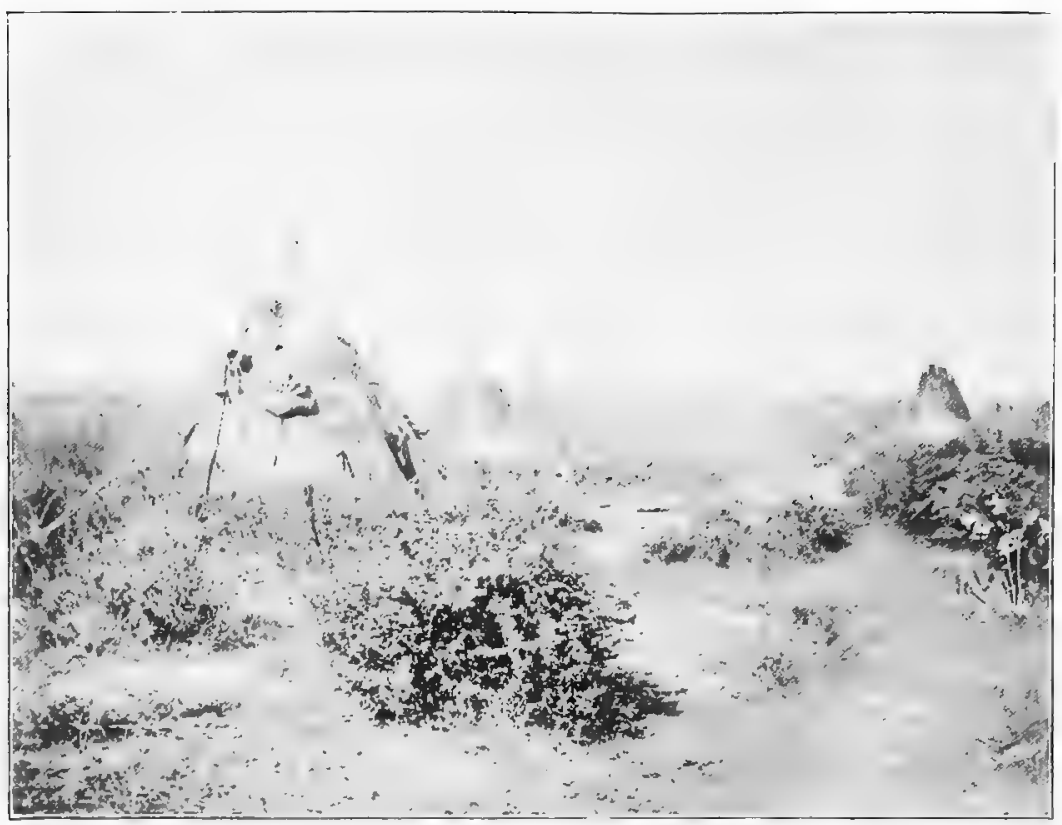

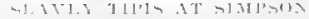

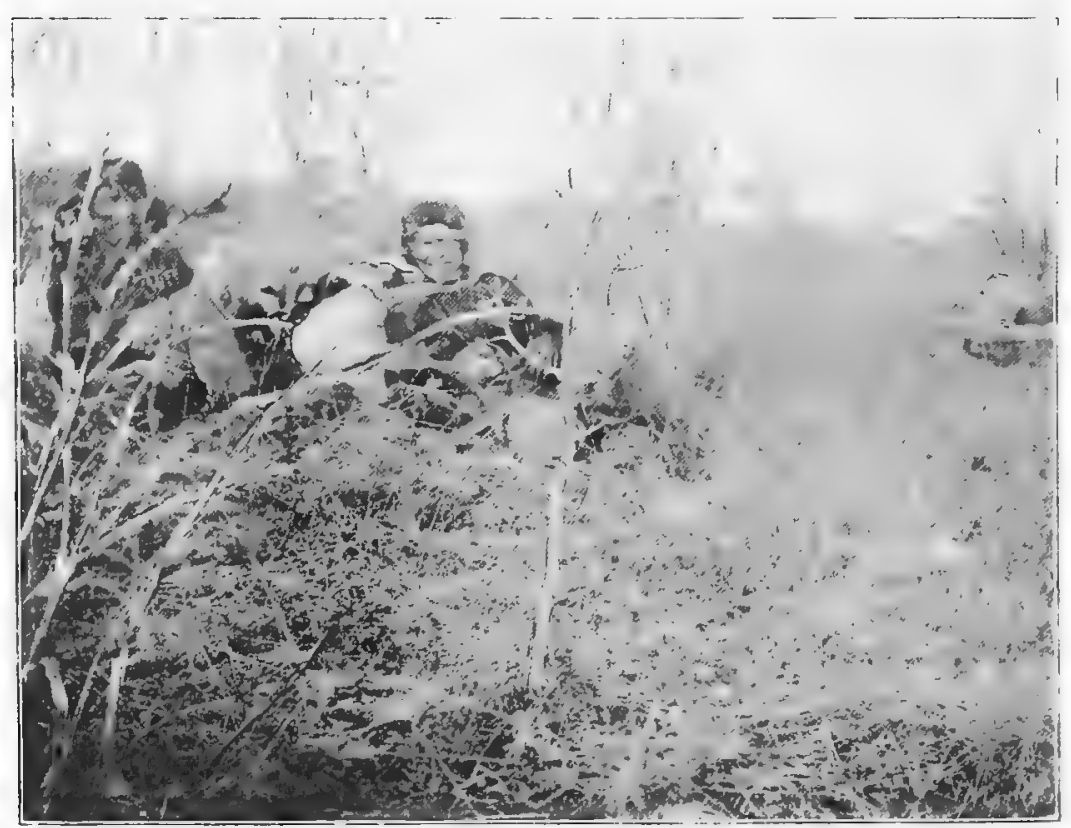

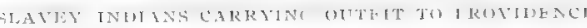


Twelve miles above Providence the narrow channel which we were following terminated in an ice jam. We again cached the load, and continued on foot, reaching the post on the evening of the eleventh day after leaving Rae. I paid the men well for their work and gave them several skins of ammunition besides, which did not deter them from stealing all the powder from the cache when they returned to their camp.

On the 29th the ice had not yet broken up, and a letter from Willow River informed us that the steamer would leave on June 2nd, if the ice permitted. I hired two men to pack down my outfit, and accompanied them to the cache that evening. By carrying a heavy load myself we were able to bring everything except the sled and harness, for which I had no further use. That evening, while Mr. Scott was paying the men in the store, some of their friends, taking advantage of the absence of everyone from the kitchen, stole the fish and potatoes that were standing, cooked for our dinner, upon the stove.

Providence, or as it is usually called, "The Rapids," stands upon the north bank of the Mackenzie, forty miles below the Great Slave Lake and twenty above the Little Lake. There is a strong current in the channel before the post, but the steamer ascends it without difficulty. Providence was originally built on Marten Lake, then near Yellow Knife Bay, then removed to Big Island, and later to its present site.

There is a small clearing, in which both the Company and the Roman Catholic mission raise barley and vegetables. The grasshoppers have made their appearance about every third year and have been more destructive to the crops than the frosts. At most of the Company's stations a few bushels of potatoes and other vegetables have been raised each year. Cattle have been kept for years at every post, until orders came in I 893 to kill them, as the expense of keeping them was too great. Sufficient hay was easily obtainable, but not of good quality. No hay had been provided for a cow which was brought to Rae, late in the fall of 1856 , so that she was fed upon dried fish through the winter. Poultry has been kept at Providence for several years. It is also fed upon dried fish, which is preferred to barley.

On the 2 nd of June I made preparations for an early start for the steamer, to which an Indian was to take me in a birch 
canoe. As the river was full of floating ice we were to follow the "slough," a channel with little current, which cuts off a large island just below the post. We found the slough covered with young ice which had formed during the night, and had to wait two hours for the morning sun to melt it. We reached the "Wrigley" at 2 P. M., and a half hour later we were steaming down the river. The ice was running in a heavy pack before us so that we ran at half speed, and even came to anchor twice to allow the swift current to clear the ice away.

We reached Simpson on the 5 th. This, the largest establishment in the north, is situated at the mouth of the Liard River. It is the central post of the Mackenzie District, to which the goods were brought in former times to be distributed to the various stations between Nelson and the Yukon. The depots are now little used. An upper floor of one of the buildings is occupied by the museum, which contains a few geological and ethnological specimens, and a number of birds and mammals which have been mounted by Captain Bell. The collection makes a creditable showing of the fauna of that region and deserves better quarters, free from dust and museum pests.

The "Mackenzie River Library" contained several hundred volumes, nearly all of which had been carried over miles of portages on men's backs, by way of the long boat route to York Factory. I there read, for the first time, the account of the Journey to a Northern Ocean in $177 x$, by that excellent observer, Samuel Hearne. I had just visited the territory which he has so quaintly described, and was in a position to appreciate the accurate and truthful account which he has given of the "Northern Indians."

We continued our journey upon the Ioth of June. Seventy miles below Simpson we passed the Nahanni River which enters from the west. The Nahanni Mountains, a spur of the Rockies, rising to a height of three thousand feet, here deflect the Mackenzie toward the north. Fifty miles below, the river breaks through this range, which extends several hundred miles farther to the northward. The higher elevations were covered with snow, though it all disappeared during the summer.

We stopped for wood, at a high bank just above Norman, where extensive beds of lignite were burning. A recently caved portion exposed a section of lignite eight feet in thickness. ${ }^{1}$

${ }^{1}$ W. F. Wentzel, an officer of the Northwest Company, wrote in 1807: 
I found the bed of edible clay, mentioned by Richardson, 1 near the base of the cliff. It is used for whitewashing at Norman, and is said to have been used as a substitute for soap by the Indians before the introduction of that article by the traders. ${ }^{2}$

Norman stands at the mouth of the Bear River near the Bear Rock, a solitary butte over four thousand feet in height. Below Norman the banks of the river were lined with mudcovered floes of rapidly melting ice, which had been deposited fifty feet above the ordinary level of the river, owing to an ice jam which had formed at the Ramparts, just south of Good Hope. At that point the river contracts to a width of less than a quarter of a mile and flows between vertical limestone cliffs, two hundred feet in height; the narrowness of the stream, and the sharp angle which it makes in its course, causes the ice to gorge on a tremendous scale at the time of its disruption in the spring.

We anchored before Good Hope at I I P. M., June I2th. Mr. C. P. Gaudette, a veteran who had been over forty years in the Company's service, was in charge of the post. With his kind assistance, I engaged an Indian to take me back in a canoe to the Ramparts, the following day. Fossils were abundant in the cliffs, but neither time nor transportation facilities permitted making as large a collection as I could have wished.

"As to volcanoes, there are some along the north side of the Grand River [Mackenzie], at a little distance this side of Bear Lake River and which are visible from this river. From these, issue several columns of smoke which have a strong smell of coal and sulpher. I was told by Mr. John Thain, one who had personally inspected them, that the fire was not above a foot under ground; the flames are pale and the smoke black; the holes from which the blazes appear, are small and numerous. No irruptions, such as are experienced in the Eastern hemisphere, ever occurred here to the knowledge of the Indians." Masson, L. R., Les Bourgeois, Vol. I, p. 79.

Lignite was burning for several miles on either side of the Mackenzie, above Bear Lake River, in 1836. Simpson, Thomas, Narrative, p. 97.

1"A pipe-clay is very generally associated with the coal beds, and is frequently found in contact with the lignite. It exists in beds varying in thickness from six inches to a foot, and is generally of a yellowish-white color, but in some places has a light lake-red tint. It is smooth, without grittiness, and when masticated has a flavor somewhat like the kernel of a hazel-nut. * * The natives eat this earth in times of scarcity, and suppose that thereby they prolong their lives." Arctic Searching Expedition, p. II8.

Ibid, p. I I9. 
The "Wrigley" started up the river that afternoon on her first trip of the season to Fort Smith. The furs at all the posts above Good Hope, except Rae, are collected on this trip. On her return the steamer goes directly down to the only post north of Good Hope,-McPherson. ${ }^{1}$ On her third northward trip the "Wrigley" goes only to Simpson, and then returns to Willow River to be hauled out for the winter. There is but one post in the Mackenzie District-Fort Liard-which the steamer does not reach.

It was two hundred and seventy-five miles to McPherson, to which I had now to make my way as quickly as possible. I had no definite information concerning the date at which the whaleboat from Herschel Island might be expected at McPherson, and feared that if I arrived too late to accompany it that I would be unable to reach the island alone. I therefore spent no time in zoölogical explorations in that very interesting region, but set off again, the next morning, alone, in a small birch canoe. There were a few pieces to be sent down to McPherson, but the skiff which carried them was too heavily loaded to admit a passenger. The skiff would drift at night while I, not being able to sleep in the canoe, would have to camp on shore; this would prevent me from traveling in company with it, and constant association with the Indians for the past two months had not developed such a fondness for their society that I desired to have Indian guides if I could possibly travel alone.

I filled every inch of space in the canoe with a hundred and eighty pounds of baggage and left the remainder to be brought in the skiff, which I was assured would soon pass me. I started late on the morning of the I4th of June, a memorable date, as I crossed the arctic circle that afternoon and felt that I was really in the North.

The strong current of the majestic river aided me very much, even down the Grand View, which I passed the next morning, where the banks are from two to three miles apart and the river without a bend for miles, the current was still strong. I crossed to the left bank that afternoon to avoid a group of Indian cabins called "Chicago" by the officers of the "Wrigley."

${ }^{1}$ Called Peel River by the Company; the original name of McPherson is preferable, as it is not then confused with the Peel River on whose banks the station is situated. 



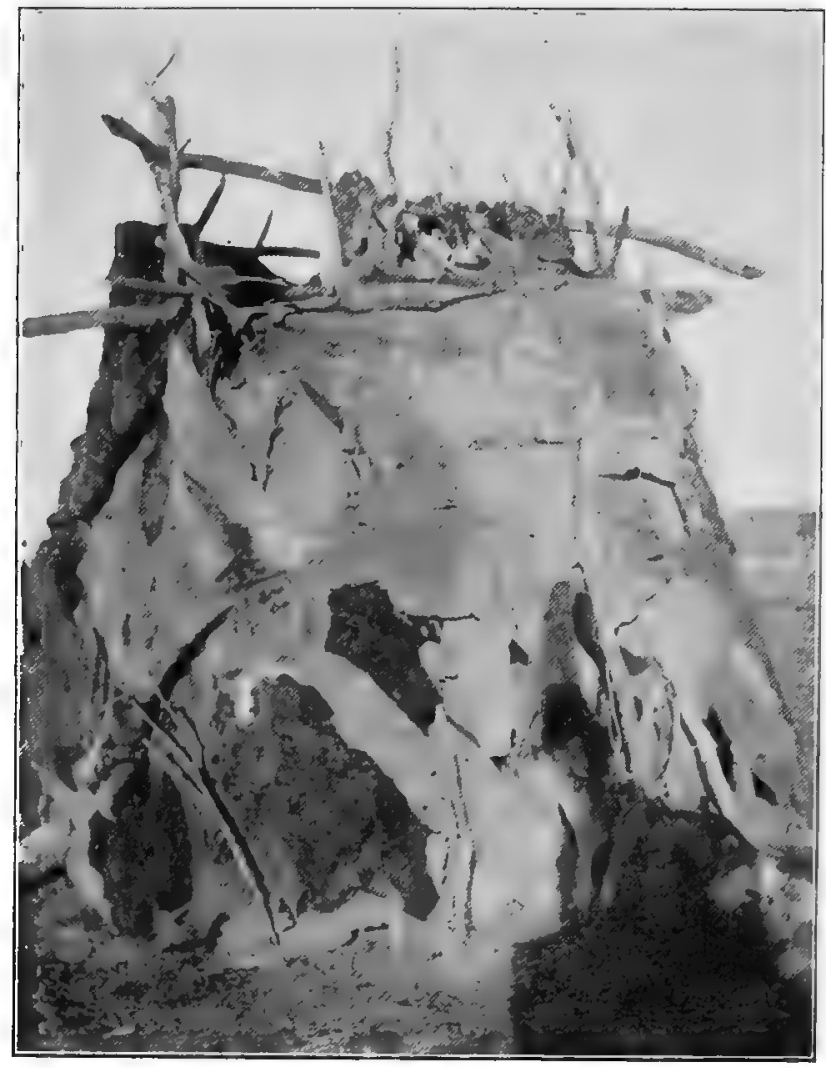

LOTCHEUX SUMMER SHELTER. MC'PHERSON, 
I camped the second night on a narrow ledge at the foot of a bank, three hundred feet in height, opposite the site of the original Fort Good Hope. ${ }^{1}$

On the third day, I was delayed by a head wind so that I only traveled fifty miles though I continued until midnight. I was then in the Land of the Midnight Sun which enabled me to travel at any time. I soon became accustomed to the continuous sunshine and came to prefer it to the usual alternation of daylight and darkness. To save time, I ate my meals while drifting and spent very little time ashore.

I passed several camps of Loucheux Indians whowere living in canvas tents or low lodges of loose skins, pitched at the mouths of tributary streams where the eddies supplied them with fish. I avoided them as much as possible, not having the tea and tobacco to satisfy their importunities, nor time to waste in relieving their curiosity at sight of a solitary "Chi-sai-witc-in" (white man). As soon as they saw that I was going past without stopping they would dash pell-mell down the bank, and come off in their canoes, following me for a mile or two to beg for "lee tea." I expected to find a large band of Loucheux at the mouth of the Red River, to avoid which I kept along the opposite bank. I could see their lodges plainly, and was just congratulating myself on having escaped them, when I reached the sharp turn to the northwest below the Lower Ramparts and suddenly found myself within a hundred yards of a dozen lodges. All was in an uproar in a moment. Some rushed toward the canoes, others began shouting and beckoning to me to come ashore. I thought that the men with the skiff must be close at hand and its occupants had more time to waste than I, so I pointed up the river and imitated the motion of rowing at which they left their canoes and several climbed the high bank to watch for the boat.

An eccentric little windmill, made of three pieces of spruce, was wobbling at a rapid rate on a stake set up in a conspicuous place on the bank. Unlike the superstitious natives about

1 Between the date of Franklin's second voyage in 1826, and that of Simpson, in 1836 , the post was moved to Manitou Island, opposite its present site. The island was flooded with "two fathoms" of water during the June rise of 1836 , which mowed down the forest and injured, but did not carry away, the buildings. The inhabitants escaped in a boat to a lake in the center of the island. Simpson, Thomas, "Narrative," p. 99. 
New Amsterdam, the Loucheux are not afraid of windmills, and amuse themselves by making simple toy wheels, since the windmill was put up by the mission at McPherson. A strong head wind blew steadily all day. The long sweep of the river around Point Separation was fully exposed to the wind which, blowing against the current, raised such a sea that progress was not only retarded but rendered dangerous. This point, at the head of the Delta, was so named by Franklin when, in I826, he divided his party to send Richardson down the eastern channels to the coast. Twenty-two years later Dr. Richardson again reached Point Separation, where he deposited a case of pemmican at the foot of one of the many lop-sticks, for the use of Franklin's party should any survivors succeed in reaching and ascending the Mackenzie. ${ }^{1}$

Many sanguinary conflicts have occurred there between Loucheux and Eskimos." The "Huskies," who annually ascend the river to trade at McPherson, are said to "make themselves awkward" if they meet a party weaker than themselves, so that I was inclined to give them as wide a berth as possible.

I started early, on the fifth day, and soon entered the narrow channel, with many tedious windings, by which the "Wrigley" ascends the Peel to McPherson.

The frozen banks were being rapidly undermined, the falling

3 British Arctic Blue Book, Vol. 35, p. 2.

In a paper to the Institute of Rupert's Land the Rev. W. W. Kirkby writes: "Between Point Separation and Peel's River [Fort McPherson], we met several parties of Esquimaux, all of whom from their thievish propensities gave us a great deal of trouble, and very glad were we to escape out of their hands without loss or injury. They are a fine-looking race of people, and from their general habits and appearance I imagine them to be much more intelligent than the Indians." Hind., H. Y., The Labrador Peninsula, Vol. II, p. I64.

In I790 Mr. Duncan Levingstone, of the North-West Company, with four servants, was killed by the Eskimos at Point Separation, while "on a voy. age of discovery." Masson, Les Bourgeois, Vol. I, p. 95.

Pullen gives an account of the cowardly massacre there of a party of Eskimos by a band of Loucheux at the instigation of a Canadian. British Arctic Blue Book, I852, Vol. 50, p. 54.

On another occasion the two nations had met on friendly terms, but during a dance, the Eskimos had suddenly drawn knives from their wide sleeves and attacked the Loucheux. In the conflict which ensued several were slain on both sides. Richardson, Arctic Searching Expedition, p. 133. 



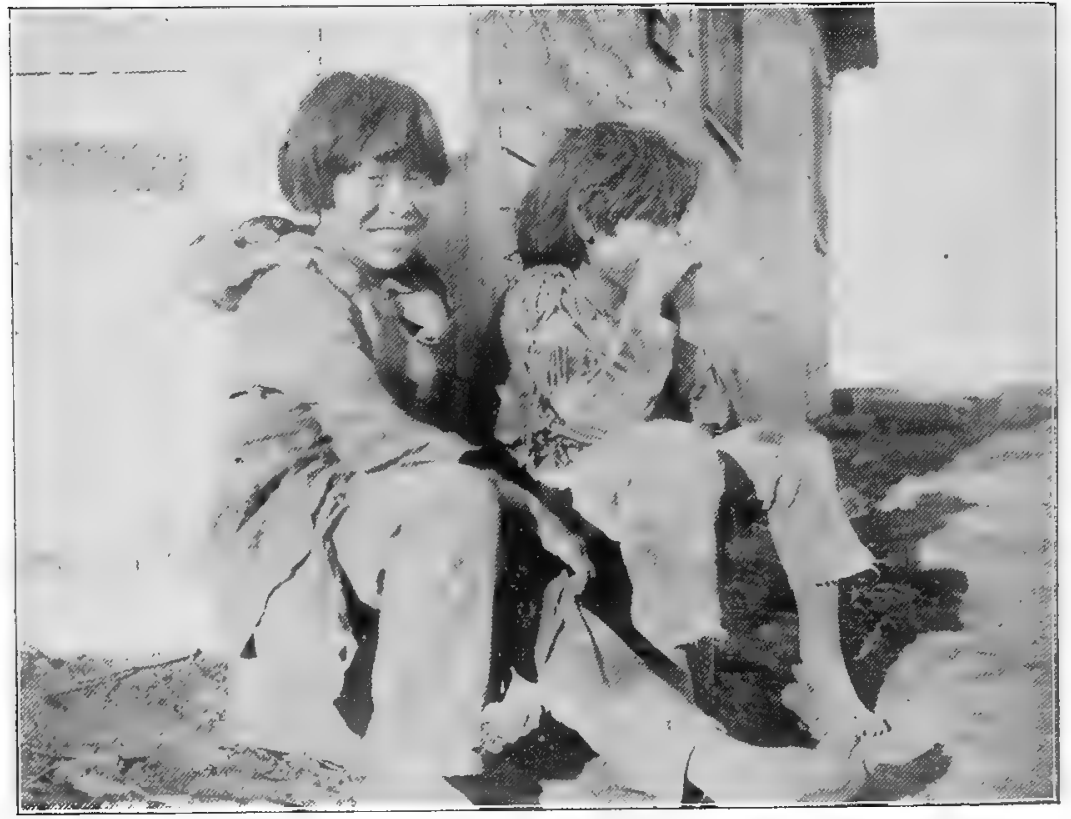

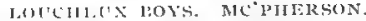


earth was a source of constant danger, as I found it necessary to keep close to the banks in order to make any headway against the swift current. I made slow progress, often advancing only by digging the paddle into the bank and fighting my way inch by inch. I reached McPherson at $3 \mathrm{~A}$. M. on the I 9 th. I had been five days on the journey, and had paddled twenty-two hours to make the last forty miles, most of that distance being against the current of the Peel River. The skiff did not arrive until the day following, on account of being delayed by the strong wind which had caused me such heavy paddling on the third and fourth days.

When I landed fifteen to twenty Indians and métis youths were playing football in the quadrangular space before the big house. They slept during the day, when both the sun and mosquitoes were troublesome, and at "night," when the sun shone just above the forest to the northward, they visited their nets, hunted waterfowl in the partially frozen lakes near by, or chased a homemade football in a noisy pack. They all came to the landing place to shake hands and to carry my baggage up the steep bank. They could see that I had a little flour, a luxury the last pound of which had been consumed at that post months before, and I heard them speculating as to the probability of the various muskimoots containing tea and tobacco.

No boat had arrived from Herschel Island. I found that the explorer, Count de Sainville, was preparing to go by canoe to Herschel Island, also with the intention of taking passage for San Francisco. It would be much safer and much pleasanter to have company on the journey, I therefore waited a few days for the Count to complete his arrangements for departure.

I took advantage of the opportunity to write letters which would be forwarded by the "Wrigley," which would arrive about July I 5 th. I then occupied the time in collecting ethnological specimens and writing a vocabulary of common Loucheux words.

As there were no goods in the store I was not very successful in obtaining specimens from the natives. A few pounds of tea would have enabled me to purchase anything they possessed.

Plain mooseskin moccasins were valued at one skin, beaded ones, two skins; plain mooseskin hunting shirt, four skins; orna- 
mented with fringe, ribbon, and quills, ten skins. The Loucheux, before the advent of the whites, wore caribouskin clothing. The upper garment had a pointed skirt which reached to the knee. The trousers and shoes were joined together, as in those worn by the Eskimo women. This pretty and serviceable costume is no longer worn. There was but one old woman at the post who knew how to make it; she asked only fifty skins for a suit of white caribouskin, as soft as chamois leather, tastefully trimmed with quill-wrapped fringe and beads.

The Count had spent four years in the Lower Mackenzie region and had so gained the confidence of the natives that two of them were willing to assist him to reach Herschel Island, which was in the territory of their hereditary enemies, the Eskimos-though the two races were then at peace-and we would have to traverse a hundred miles of unknown seacoast, after leaving the mouth of the river.

I left the Slavey canoe in which I had come from Good Hope at McPherson, and continued in a small Loucheux birch canoe which had broadly flaring sides, so that it was not at all cranky. It was thirty-two inches in the beam, but it was roughly made and quite "slow." It was fourteen feet in length along the water line and fourteen inches in depth. The Count had a large canvas-covered canoe, which three men could drive at the rate of about four miles an hour when loaded with eight hundred pounds of baggage.

We started for Herschel Island on the $25^{\text {th }}$ of June. Twelve miles below the post the Peel divides into a number of channels, some of which flow toward Point Separation, while others extend nearly to the ocean before mingling their waters with those of the Mackenzie. During the afternoon a strong head wind raised such high waves in the current that we traveled at considerable risk and frequently shipped water.

Muskrats were abundant in the many channels, and ducks, geese, cranes, swans, and loons filled the air with discordant sounds at all hours. Several bald eagles were seen during the day, one of which Vusso killed for its skin which he carried to the coast to trade with the Eskimos. We camped that evening on a point that was covered with the fresh tracks of two grizzly bears.

The sun shone throughout the twenty-four hours of the day, 
and with such power that the snows were melted to a high altitude on the Rocky Mountains, along whose eastern base we were traveling.

The whole country had been flooded a few days before, at the time of the breaking up of the ice that still remained in considerable quantities of black and dripping blocks along the banks. It was difficult to find enough brush to keep our blankets out of the mud which had been deposited by the receding waters. The hares in the Delta had been drowned during the overflow, and we frequently saw their dead bodies suspended among the willows.

As we continued next day the waterfowl became more abundant in the ponds which covered the interior of the islands. All through the cooler part of the day, or night, when the sun hung low in the north, the melodious call of the long-tailed duck, Clangula hyemalis (Linn.), (known to Eskimos by the name a-hau-l'iñ, and to the whites by another onomatopecaccawe) could be heard. I never tired of hearing the note of this duck, which rang out with such wild, mirth-provoking freedom, in contrast with the hideous scream of the loon, Colymbus pacificus Lawr.

The Count assured me that the area covered by water exceeded the timbered portion of the Delta in extent, as viewed by him from the summit of the Black Mountain, just east of which we were passing. Moose and bear tracks were frequently seen. Lieutenant Pullen, who entered the mouth of the Mackenzie on the 27 th of August, I 850 , reported "tracks of bears, moose and reindeer frequent." On the morning of the third day a wolverine was wounded but escaped. We killed geese, ducks, and muskrats and, with the flour which I had brought, we were well provisioned. At 7 P. M., as we were quietly paddling around a long bend, with a low muddy shore, we caught sight of a large grizzly bear walking down stream by the water's edge. As I was the only member of the party who had a rifle, I hastened to draw it from its case and to push forward to get a shot at close range. The bear, without seeing us, entered the stream with the evident intention of swimming across. "Be careful," said the Indians, "he is a wicked beast. If you kill him, you must grab him or he will sink." I was within fifty yards of the animal before he discovered our presence. He 
uttered a roar of rage as he realized his disadvantage, and at once turned back toward the shore which he had just quitted. He held his head well out of the water and continued growling, though he swam rapidly. I waited until he gained a foothold at the shallow margin before I fired. The bullet struck a little above his heart, rendering him helpless but not killing him. He sank to the frozen earth through a foot of soft mud in which he floundered and rolled until no longer recognizable as a bear. It was not difficult then to finish him. We had not met on equal terms, yet I had not felt altogether at ease in attempting to approach and fire from the cranky little canoe which veered quickly when I dropped the paddle to use the rifle, nor did I relish the idea of "grabbing" a dying grizzly to keep him from sinking. As there was no suitable camping place near at hand, we towed the bear a quarter of a mile across the river. It required all of one man's strength to raise the body to the surface in approaching the shore. It was a five-year old male, still in prime condition. We celebrated the event by having a feast of ducks and fresh bread. As I wished to preserve the skin for mounting, it took us some time to remove it, and it was $3 \mathrm{~A}$. $\mathrm{M}$. before we sought our tired pillows.

On the fifth day we passed the last stunted and flat-topped spruce; the channels were fringed with willows nearly to the coast, which was reached the following day. The larger lakes were still covered with ice, though the sea was open to the horizon.

We had been delayed while descending the river by the wind which blew continually on our bows. Though our progress was slow, we were not prevented from traveling, but throughout the voyage before us, along a hundred miles of unprotected sea coast, we would be driven ashore by every strong breeze, unless it blew off the land. My pleasure at beholding the Arctic Ocean at last, was mingled with apprehension at the thought of how unsuitable was the craft with which I would have to traverse its ice-laden waters.

We had first to cross an indentation of the coast, called Shoalwater Bay, which lies between the mouth of the westernmost channel of the Mackenzie and the delta of a mountain stream thrown out some miles from the hills. We were over an hour making this traverse, where even a moderate wind would have 
quickly raised a choppy and dangerous sea, and the extensive mud flats inshore would have made a landing difficult. When midway across, a bumblebee flew past my canoe, straight from the north, toward the land, over two miles distant.

As we approached the battures beyond the bay, we were saluted by several rifle shots fired by two Eskimos, whose camp was pitched on the beach, at the mouth of one of the channels. They were living in a new wall tent, which they had obtained from the whalers; several bags of flour, as much as some northern posts receive for a year's allowance, piled under an overturned omiak, had also come from Herschel Island. A quantity of fresh caribou meat and herring was hanging on a scaffold near by; the woman was kneeling before a wooden vessel of native manufacture, that resembled a neatly-made peck measure, in which she was kneading dough. Such a display of provision and the salute accorded us caused us to land, of course. We were hospitably received by the head of the family, a tall ferocious looking fellow, whose natural ugliness was enhanced by the presence of a disc labret, as large as a silver dollar, in his lower lip.

The Indians conversed with the Eskimos in the trade jargon of the coast, which included even Kanaka words in its vocabulary. We learned that they had just come from Herschel Island, where the "Yankee ships" had been left firmly frozen in.

They were all dressed in caribou or sealskin garments. Their well-made and serviceable clothing was markedly superior to the tattered and inadequate dress of the Indians. Like many other things invented by the Eskimo, his dress is superior to any which the white man can give him. The woman wore an artega, so broad at the shoulders that she could draw in her arm without using the other hand to assist in the act. I was puzzled at first sight of the empty sleeve, as I thought, surely, she cannot be one-armed, but the mystery was explained as she thrust out the arm again with two or three circling flops of the sleeve, still keeping the other hand engaged with the kettles. The short-skirted artega was at first scarcely distinguishable from the frock worn by the two men, father and son, nor could I have known their sex from their manner; the woman talked with the air of an equal, instead of maintaining silence, or with the slavish behavior of the Indian women in the presence of 
strangers. Her costume, though ultra bicyclienne, could but impress one observing such an entire novelty for the first time, as being becoming and sensible. Their clothing was trimmed with the white-haired Asiatic reindeerskin, carcajou and wolfskin.

The two younger children fried the bread, which had been prepared for us, in a pan of seal oil over an open fire of driftwood. The cakes were of the usual Eskimo shape-oblong, and perforated with three pairs of holes. As soon as this doughnut-bread was ready, we were invited into the tightly-closed tent where we succeeded in eating one meal without being tormented by the ubiquitous mosquitoes. In addition to venison and bread, we were given syrup and coffee, articles quite unknown in the interior; the Eskimos of that coast do not use tea.

As we reëmbarked, the woman brought some venison from the stage and threw into each canoe; this act of unsolicited generosity but completed the favorable impression which their conduct had made. The Indian treatment would have begun with begging for tea, and if we had been called back it would have been for the purpose of begging for more tea.

By wading and dragging our canoes for a mile, through a shallow channel, we avoided a long detour around the outlying reefs. The temperature of both air and water was near the freezing point, and our respect for the mighty deep had changed to profound disgust before we reached deeper water again. We early encountered more serious detentions than those caused by shoals. A north wind soon drove us ashore, where we pitched our tent on low ground, with nothing but watersoaked fuel to be had. The wind kept the wet logs blazing, but it pierced through our winter clothing and made the halfclad Loucheux wish that they were within the shelter of the woods again.

The Mackenzie brings down immense quantities of driftwood that is strewn for hundreds of miles along the coast. The largest logs, of spruce and rough-barked poplar, come from the distant Liard. The sand beaches of the coast are literally covered with the white trunks from which the bark and branches have been worn.

The volume of water poured out by the Mackenzie is sufficient to keep the sea fresh and clear of ice for many miles. As 
we passed Escape Reef, the scene of Franklin's adventure with the then numerous Eskimos, we entered the salt water in which we first encountered ice. The floes became more abundant until we found ourselves threading our way through a narrow channel between the ice pack and perpendicular, frozen mud cliffs which rose to a height of one to two hundred feet.

The "Glorious Fourth" was ushered in by the sun standing $I^{\prime}$ and $43^{\prime}$ above the northern horizon at midnight. South of us the lofty, snow-crowned peaks of the Rockies formed a fitting background to one of the most beautiful scenes that I have ever witnessed. The gently rolling hills near the sea were literally covered with flowers, though every ravine was filled with snow. Along the beach the ice was piled in great masses where it had been driven by the wind. Along the northern horizon the floes were closely packed, they floated about us, worn into a variety of grotesque forms by the action of the waves. A faint rosy haze hung over all and suffused and softened the harsh details. At intervals, we passed lagoons inclosed by barriers of sand strewn with driftwood. The Eskimos have encamped for ages upon these beaches; the sites of even their temporary summer camps were marked by cones of short logs set up to keep the wood dry or out of the snow. The winter settlement of Peockcha at Shingle Point was deserted, though there was evidence of its having been occupied during the previous winter. On the high grounds, back of these abandoned camps, were oblong heaps of driftwood, erected over the remains of the dead, which could not easily be interred without tools for digging in the frozen earth.

During the night of the $4^{\text {th }}$ we came upon a family of white foxes, close to the water's edge, and succeeded in capturing two of the young. The siffleux were very abundant, their note of alarm sounded continually from the cliffs above us. Waterfowl were not numerous, and our fare was reduced to redthroated loons and tea. A few ravens were perched about the face of the black and thawing cliffs; these birds were probably attracted by the carcasses of stranded whales which had drifted in from the whaling grounds.

We found a party of natives at Warren Point, whose new canvas wall tents were pitched within a few feet of the sea. The tide rises less than two feet on that coast, and the presence of 
the ice field at that season prevented the sea from being driven in by storms. They had no kaiaks, but set their herring nets with the aid of two or three slender poles spliced together, one end of the net being made fast ashore and the other pushed out from the beach. At our approach they talked and gesticulated in an animated manner. As they walked I noticed the characteristic gait, so frequently mentioned, and usually called "rolling," though the term does not describe it. They are usually considered greatly inferior to the Indians as runners. They are a seafaring race, who hunt caribou in summer only, and at that season the yielding moss would tend to develop, rather than correct, the peculiarity in their stride. The custom of shaking hands, which is so ceremoniously observed by the Indians, was treated rather as a joke by the Eskimos; they would grasp a proffered hand, but with an air of doing so merely to oblige. Some of the men were of tall stature, one of them must have exceeded six feet, and his nose was quite prominent." They were "Anderson River Eskimos," from the coast east of the Mackenzie. The dogs at this camp were large and well fed. The curled tails, erect ears, and heavy coats indicated the pure blood Eskimo dog. They were black in color with white markings.

On the fifth a strong northwest wind, accompanied by rain and snow, prevented traveling. Fortunately, we had a small tent which protected the Count and myself from the violence of the storm. The Indians improvised a shelter from a piece of boat canvas, which they stretched over drift willow sticks, arched in the form of the Loucheux lodge, which resembles an Eskimo ice hut in shape. They crouched under this low roof and passed the time in sleep or chattered with banter and laughter about the strange sights of the sea. After we had been delayed thirty-six hours, the wind suddenly shifted to the southward, allowing us to proceed. We had to make quick work of loading the canoes to avoid being nipped by the floes, which were driven rapidly along by a strong tide. The ice had accumulated during our halt, so that further progress was impossible until the change of wind again drove it offshore.

1"II est parmi eux des hommes fort grands, mais la taille des femmes est généralement petite." Petitot, Monographe, p. 4.

Compare Kelly, Arctic Eskimos in Alaska and Siberia, p. 5 . 
There was still a heavy sea running as we passed Kay Point, where the deepest soundings of the entire coast are found, and we rounded the point with no little difficulty and danger. Twenty miles to the northwestward, the rolling hills of Herschel Island, rising five hundred feet above the sea, were plainly visible. All about us were scattered the grounded floes, worn in arched hollows, in which the waves beat in reverberating monotony. A few yards from shore the unbroken ice of winter extended beyond the limits of our view.

Phillips Bay is partly enclosed by a narrow sandspit upon which is situated the permanent Eskimo settlement of Tekara. The inhabitants were then living in their summer tents. We were scarcely able to reach this camp before the wind, now on our bows, compelled us to land. The Eskimos asked us to enter their tents, which were comparatively clean and comfortable, but smelled strongly of the rancid whale oil, or oakchoak, which taints everything that an Eskimo even touches. Four or five recently-killed seals were being cared for, and fish seemed to be abundant. One old man kept a constant lookout with a long glass for seals. Coffee, flour and syrup from the whaling vessels were used by every family. In twenty-four hours the sea again fell so that we reached the mainland, where we were stopped by the ice field, which was grounded inshore and in places piled high upon the beach. The tent was again pitched on the bar at the mouth of a mountain creek that supplied us with fresh water. Every gully was full of hardened snow which. looked as if it would last through the summer.

While the men slept I examined the graves on the brow of the hill overlooking the camp. In one of such great age that the logs were scarcely distinguishable, and the skull was disarticulated, I found a pair of marble labrets of the usual stud-shaped pattern. An omiak and two kaiak frames, kumotiks, a repeating rifle, bows, arrows, harpoons, ornaments, amulets, cooking utensils, etc., were lying beside the graves. When I returned to camp I found the two men quietly sleeping in a tarpaulin, which was burning in several places; the wind had changed to the westward and carried sparks from the fire upon their covering. They were chagrined at the predicament in which they found themselves, but as long as they escaped with a whole skin, "coca"-never mind. 
As the wind rose the whole ice field moved fifteen to twenty yards from shore, enabling us to proceed by making occasional portages over narrow barriers of jammed ice. The field was marked by pits and channels, a few inches in depth, some of which were deep enough to be utilized in passing obstructed points. Several times I attempted to pass through such a channel, only to find the bottom covered with mud which gave it a false appearance of depth, and to have the canoe strike hard and fast. The rough and jagged ice soon wore away the gum from the seams, but with care the bark itself escaped injury. After five hours' paddling we reached a large settlement of natives, situated upon the mainland, twelve miles south of the harbor. They assured us that it would be impossible to reach the island, and that we might as well camp with them for a few days. One look at them was enough to convince me that we had better move on if possible. They were dressed in the most grotesque costumes, and their dissipated looks did not tend to inspire confidence. Those who wore the native frocks kept their hoods, bordered with long wolf hair, drawn closely about their faces to protect them from the attacks of the swarms of mosquitoes. One of the men wore a new sombrero with a very broad brim. Others had miscellaneous odds and ends combined with their native costumes, with the effect on the beholder of having discarded a portion of their apparel and substituted. an incongruous textile fabric to mark the loss. Several wore tight-fitting, red flannel drawers over their deerskin trousers.

We continued a few miles along the shore, finding progress more and more difficult, until we reached the long projecting sandspit which extends to within a mile of a similar bar from the southeastern point of Herschel Island. After searching for some time to find a passage through the closely-packed floes, with much chopping and pushing to clear our way, and with some portaging, we reached the island, where we found the ice firmly jammed against the cliffs, and further progress toward the harbor, seven miles distant, impossible. We could, of course, now travel overland, but as we were quite exhausted with thirty-six hours' work without sleep, we sought first to obtain a little rest before continuing.

We ate our last bread and a bit of cold loon, set up our mosquito canopies on the sand, and were soon soundly sleeping. 


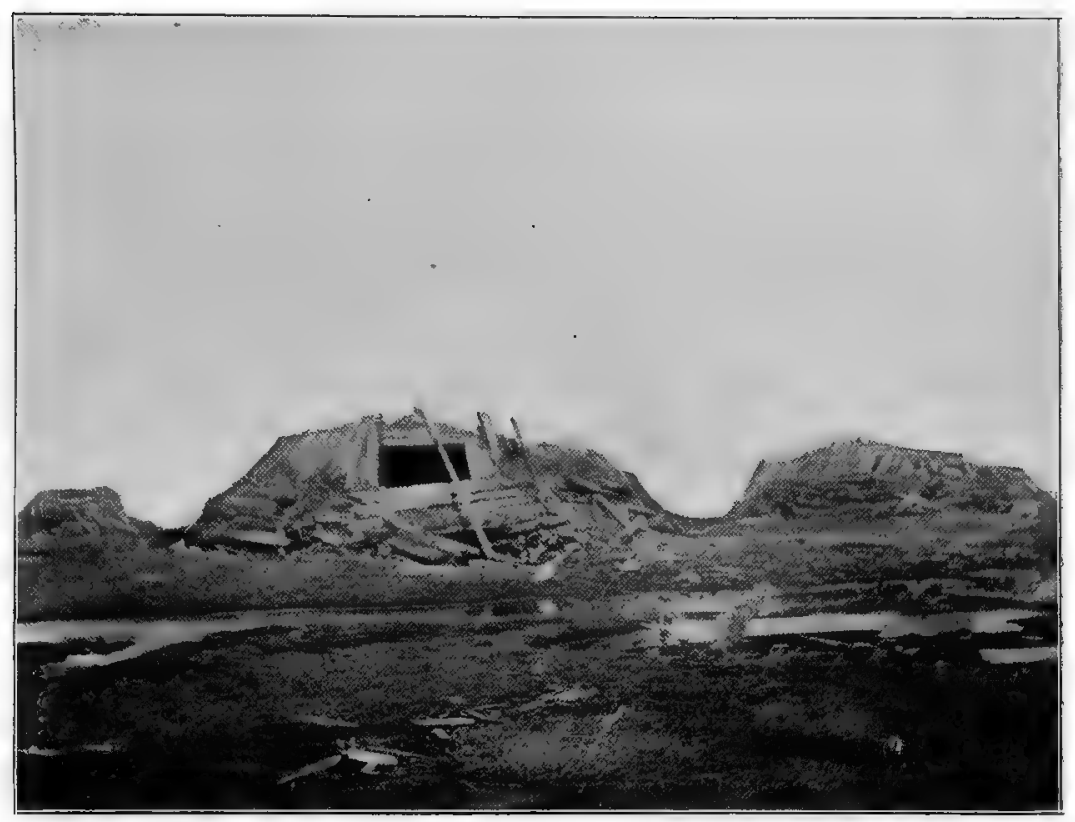

ESKIMO HUTS OF DRIFTWOOD, HERSCHEL ISLAND. 

The midday sun shone directly upon us, the mosquitoes added their vicious and irritating hum to the owdk tchowdk of the waves in the hollows and the grinding of the floes as the tidal currents moved them.

It is said to be more difficult to sleep upon sand than upon rock. I could see little difference myself, but we slept very soundly, nevertheless, for two hours, when Tothin awakened us with the information that the ice was moving. We were not in a mood to care if Herschel Island were adrift and were not pleased to find the barrier as firm as ever. The wind was blowing from a favorable quarter and increasing, so that the ice field, which a few yards out was not yet broken up, soon moved enough to form a narrow lane at the base of the cliffs, through which we beat our way against the gusts of wind and rain which came whirling down the gulches of the rugged coast. At midnight, July 8th, we were within six hundred yards of the vessels, which were lying close together near the beach. They were held at their anchorage by heavy floes, driven in by the ice field. We could neither land upon the muddy precipice nor continue farther with the canoes; a kumotik was sent to our rescue, upon which the baggage was placed by a half dozen Eskimos and sailors. I could not have believed it possible for men to walk over such ice as we traversed before reaching the vessels. Two or three of the men missed their footing in jumping on the loose floes and were ducked in three fathoms of water. The Count and I wore common leather shoes, which were not so well adapted to use upon the ice as the flexible soled Eskimo boots worn by the sailors, and our wild leaps must have been highly amusing to the spectators. We were hospitably received on board the bark "Balaena" by the assembled officers of the fleet. We brought them news only five months old.

The journey from the mouth of the Mackenzie had occupied eight days; had we had a boat, instead of the light canoes, we could have easily reached the island in three days. Sir John Franklin, who was the first white man to explore that coast, reached Herschel Island on the 17 th of July, I826, ten days out from the Mackenzie. His party had two boats, one twenty-four and the other twenty-six feet in length. Dease and Simpson, in I837, left the mouth of the Mackenzie on the gth of July and reached Herschel Island on the $\mathbf{I} 4$ th. They were traveling in 
two clinker-built boats of twenty-four foot keel. In I850 Lieutenant Pullen passed the island on the 22nd of August and entered the river on the 27 th.

We had reached the island just in time. The two heaviest steamers had been "bucking" the ice during the preceding day and had nearly reached the point of the bar enclosing the harbor. Toward the northeast the sea was open, and a whaleboat had been sent to the mouth of the Mackenzie to meet the Count, but had been turned back by the ice encountered there. During the night of the Ioth a second and successful attempt was made to escape from the imprisoning floes. Each captain took his place in the crow's nest at the foremast head, whence the whole field of ice could be seen. The "Balaena" and "Narwhal" were the heaviest vessels, and consequently the most successful in their attacks upon the ice which was tightly held at the extremity of the sandspit. I was on board one of the vessels as she worked herway around. The ice was broken by the weight of the vessels and not by the shock. The bow would rise until the ice could no longer sustain the weight, when it settled and the vessel would back off for another blow. By 2 A. M. on the $\mathrm{rIth}$, the last vessel was anchored outside and the crews sent to bring off the whaleboats, which had been lying on the beach. An hour later the last steamer had disappeared in the fogs toward the eastward. They were on their way to the whaling grounds between Richard's Island and Cape Bathurst, where, during the preceding summer, they had made the greatest catch in the history of Arctic whaling, the "Narwhal" having taken sixty-four bowhead whales, the "Balaena" sixty-two, and the others from nine to forty each. The sea had been unusually open during the summer of I893; one of the vessels had followed the coast of Banks' Land for some distance to the northward without encountering ice.

A few buildings have been erected on the sandspit which encloses Pauline Harbor, in which to store whalebone and supplies. Three men were left to guard this property from fire, the natives who remained about the place being quite indifferent to the fact that their camp fires were built within a few feet of half a million dollars worth of whalebone.

The officer in charge of the station, Captain E. C. Murray, went on board the "Balaena" for the summer, so that the men 
could not leave their post; there were no Eskimos to be hired, so that I was obliged to go alone if I visited the mainland.

There were only a few species of birds to be found about the station. I was desirous of securing specimens of ptarmigan in summer plumage, but there were none to be found upon the island, where they had been abundant during the winter.

It rained or snowed frequently and continual fogs made outdoor work very unpleasant. Two days after the departure of the vessels there was not a cake of ice left in the harbor, but the ice field was unbroken west of the island.

On the Igth I started for the mainland in a heavy dingy. I had to reef the leg-o'-mutton sail before the steady breeze which was carrying me rapidly toward the point of the island. To my consternation I discovered after an hour's sailing that the ice floes had gathered along shore, forming a barrier three or four hundred yards in width; and a field of solid ice prevented me from sailing within a quarter of a mile of the point. I was being driven into a pocket from which it was impossible to beat my way in the flat-bottomed dingy. There was nothing to do but run into the tossing and grinding floes and at least make my own escape, if the boat should be crushed. Running in between two floes, each about twenty yards in diameter, I succeeded in getting the bow of the boat upon one of them before it was nipped. After two hours' hard work I reached the beach, having to cut footholes and drag the boat over the ice one end at a time. I had landed at the debouchure of a little coulée, twenty yards in width, in the bottom of which there was sufficient driftwood for fuel. On each side the overhanging walls of snow'and ice rose to a height of sixty feet. The next day showed no change in the condition of the ice. I could not launch the boat, so the day was spent in examining the abandoned Eskimo village at the southern point of the island. The remains of two other ancient settlements exist at the harbor and at the southwestern extremity of the island. The wretched hovels, built of driftwood, covered with earth, stood on the low, sandy beach. After the departure of the few families which had occupied them the previous winter, the huts had filled with snow through the open roofs. The floor was of earth, the walls of unhewn logs. The low entrance-ways were caving in and filled with water or ice. 
The gale, accompanied by frequent showers of rain, continued during the third day. The ice was rapidly breaking up and disappearing, not drifting away, but being pounded out of existence by the heavy seas. The main field was four feet in thickness and several square miles in extent. Small bergs, ten to fifteen feet in height, were driven into this, and they too were soon transformed into seawater. I occupied a part of the day in baking bread in the frying pan before a fire of wet logs and concluded that a sandy beach and a strong wind is not a happy combination for open air baking. On the 22nd I reached the southwestern extremity of the island, about seven miles distant. I could not reach the mainland owing to the extensive mudflats, which the low tide exposed, but camped for the night on the narrow sandbar which extends three miles from that extremity of the island. The day following the wind was blowing too strong for the dingy to weather it, and I did not get away until evening, when I rowed westward along the fringing reefs, which extend with little interruption to Point Barrow. I halted at a high island of only a few acres extent, where a considerable portion of the property of a band of Eskimos, who were hunting caribou inland, was lying upon stages. I was opposite the mouth of a large creek which flowed through a gap in the mountains, ten or twelve miles distant. The stream had spread in its rapid descent over several miles of plain, across which running water appeared in at least fifty shallow channels. With a canoe, I could have ascended this without great difficulty, but I found it impossible to drag the heavy boat more than five miles through the shallow rapids. I saw but few caribou, and they kept well out on the level ground, where there was not even a creeping shrub to afford cover in stalking. I watched them for some time with the field glasses and noted the fact that they seemed to be greatly annoyed by insects. They were then clothed in the short summer hair and the antlers of the males were of large size.

Returning to the eastward, I camped on the mainland and spent the next ten days in collecting birds. I saw no ptarmigan, though they had been common between the Mackenzie and Kay Point. Red-throated loons and cacawees were the most abundant of the water birds. Ravens were common, perhaps attracted by the carcasses of whales, seven of which were within 
five miles of the camp. Sparrows and longspurs were everywhere abundant. I collected a few siffleux, one of which I boiled to test the quality of its flesh; it tasted much as a house rat looks. The almost continual rain and fog made camping alone with a boat sail for shelter very monotonous. During the last two days the mosquitoes were unusually vicious and in such numbers that they obscured the color of my clothing and surroundings with their gray-hued legions.

During my absence one of the vessels had returned to repair a rudder, which had been broken in the ice. The officers declared that the ice was heavier and more abundant than they had ever known it to be before. They could not advance beyond Pelly Island, where one vessel had been driven ashore but had been hauled off without serious injury. No whales had been seen. Point Barrow natives, whom they had established on Bailey Island, had not secured any whales during the spring. There seemed to be some doubt among the officers of the island fleet as to whether or not the outside fleet would succeed in passing the reefs, midway between the island and Point Barrow, where the ice always lies close inshore, and, it is said, does not during some seasons open sufficiently to allow a vessel to pass at all, although the whalers have reached Mackenzie Bay each summer since I 889. During that year the United States Steamship "Thetis" visited Herschel Island and examined the harbors at the eastern and southern capes. Though Pauline harbor is half a mile in length, the extent of good anchoring ground does not exceed an area four hundred yards long by three hundred wide.

On the 8th of August signal smokes on the mainland announced the arrival of the Rat Indians who annually visit the island with dried meat and skins. The Eskimos went to meet them with a whaleboat.

Early on the morning of August igth a steam launch arrived, which had been despatched from Return Reef, where the outside fleet had been stopped by the ice. Captain Ellis reported the loss of the bark "Reindeer," which had been driven ashore by the ice. He had killed three polar bears while working through the ice, one of which he presented to the University of Iowa.

At I P. M. the first steamer hove in sight around the northern 
headland, to be followed twenty minutes later by another. Over a dozen vessels came in, attracted by the remarkably successful catch that had been made during the summer of '93. In that year the first vessel arrived at the island on the 24th, and in I892 on the Igth, of August. On the 23rd the "Jeanie," drawing over three fathoms, arrived with supplies for the vessels that were to spend a second winter at the island.

On the zoth day of August I left Herschel Island upon the brig-rigged whaling steamer "Jeanette," Captain E. W. Newth. We were to proceed at once to Wrangel Island, for a month's whaling, before starting homeward. We cruised along the edge of the ice field, to which we sometimes anchored at night if the wind permitted. Nearly every day the boats were lowered for whales, but without success.

The temperature ranged from twenty-five to thirty degrees during the night, when large quantities of ice formed upon the rigging. We were almost continually enveloped in fog or kept inside by rain and snow. On the $5^{\text {th }}$ and 6 th of September we were pitched and tossed by a northerly gale which threatened to close the ice in between us and Point Barrow. On the $7^{\text {th }}$ we steamed all day among favorable leads, only to find in the evening that we had run into a pocket from which all haste was made to escape, and we steamed all night to get back again to open water.

On the gth we fell in with three other vessels, also pushing westward. We "gammed"-visited with their captains, during the day as we steamed through a quiet sea. On the morning of the Ioth we reached Point Barrow, the northernmost point of Alaska, situated in latitude $7 \mathrm{I}^{\circ} 23^{\prime} \mathrm{N}$., longitude $156^{\circ} 40^{\prime}$ W., west of which the sea does not close until October. The inside fleet is beset at Herschel Island a month earlier. Two whaling companies have stations located at Cape Smythe, the nearest high ground, twelve miles southwest of the Point.

During the summer of ' 94 the whalers had been unusually successful and had taken twenty-one thousand pounds of whalebone. There is also a government refuge station maintained at the Cape for the benefit of the whalers.

A Mr. Brower, who had spent seven years in the country, a member of one of the whaling crews, said that with his party of natives he had killed one hundred and thirty-two caribou that 
summer. While inland, he had seen "fifty musk-ox skulls." The oldest Eskimos say that their fathers hunted musk-ox but there were no caribou then. In a large lake, south of Cape Halket, which had but a single outlet to the sea, through which no large fish could pass, he declared there were large shark-like fish, which exceeded twenty feet in length, and that he had himself seen their bones in abundance upon the beach, but had never heard of this species in the sea or in any other lake.

Near Cape Lisburne, a few miles down the coast, coal is found, and in the accompanying strata, fossil "leaves, birds, tracks, bones and shells are abundant." South of that point fossil trees are said to be common. The country about Point Barrow is a barren, gently rolling tundra, with no mountains in sight.

We left Point Barrow on the morning of September I Ith and steamed through loose pack ice for the next four days. We frequently felt a shock as the vessel struck an ice floe, because of the narrowness of the lead or the indifference of the officer in the crow's nest, who usually gave the command "port" or "starboard" in time to veer away from the ice. On the I 8 th we were tossed and rolled by an arctic gale, which drove the Count and myself to our bunks and added to the general discontent of the officers and crew. Day after day the boats had been lowered, but without killing a whale. Only one had been taken during the summer, to the eastward of Herschel Island.

On the Igth Herald Island was sighted. This island is only six miles long by two wide, and is one thousand feet high. Twenty-five miles west of it is Wrangel Land, an island seventyfive miles long by twenty-five wide, and having peaks exceeding two thousand feet in height. These islands were discovered by the English discovery ship "Herald," on the I $7^{\text {th }}$ of August, I 849 . $^{1}$

On the 2 Ist and 22 nd we rode out another gale. A cold, which I had contracted at Herschel Island, had grown steadily worse, and I had little strength left to "hang on" as the vessel rolled. The next three days saw us tossed in cross seas. Snow every day and frequent fogs prevented successful whaling. On the 26 th we ran into an immense school of whales, "Over a hundred in sight!" The five boats were lowered at 7 A. M. and

1 British Arctic Blue Book, Vol. 35, p. 9. 
were out ten hours. The second mate struck a whale which capsized the boat, but the crew were rescued by another boat. The whale sank and was lost. The vessel was kept on two hour tacks during the night and in the morning the whale, which had risen to the surface was discovered. I then had an opportunity of seeing a whale "cut in." The process occupied all hands for four hours.

That afternoon we passed two walrus, the first seen that season. Observations taken that afternoon showed that we were northwest of Herald Island in the lead which the exploring steamer "Jeannette" had entered in 1879 . The current which had carried that vessel so far after she was beset had caused our vessel to drift fifty miles toward the northwest in the last four days.

On the 28 th the young ice covered the surface of the water in broad, flaky patches. Steaming to the northward we encountered the pack in latitude $72^{\triangleleft} \mathrm{IO}^{\prime} \mathrm{N}$.

During the night of October Ist there were several whales close to the vessel, their presence being shown by the flashing phosphorescence and the sound made by their flukes striking the water. Nearly every night while in the western Arctic I noticed the brilliant phosphorescence of the water in the wake of the vessel. On the 2 nd the temperature fell to ten degrees below the freezing point. Owing to the cold and rough weather Captain Newth decided not to wait until the Ioth, the usual date of departure, before starting homeward, but on the 5 th to the joy of everyone on board the prow was turned toward the Straits and all sail was set. On the 8th five hawks rested for some time in the rigging. They had probably been blown off from the Alaskan coast by the easterly wind of the preceding day. We reached East Cape on the Ioth, where a few natives were landed with their belongings. The Eskimo settlement is situated at the extremity of the rugged headland; the low earth covered hovels cling to the steep slope like the nests of barn swallows. Three omiaks filled with men came off to the "Jeanette" which drifted rapidly in the strong tide. While they remained on board the light skin boats beat against their fenders of inflated sealskin without injury, where an ordinary whaleboat would have been dashed to pieces.

The mountains, which rise abruptly from the beach, were 



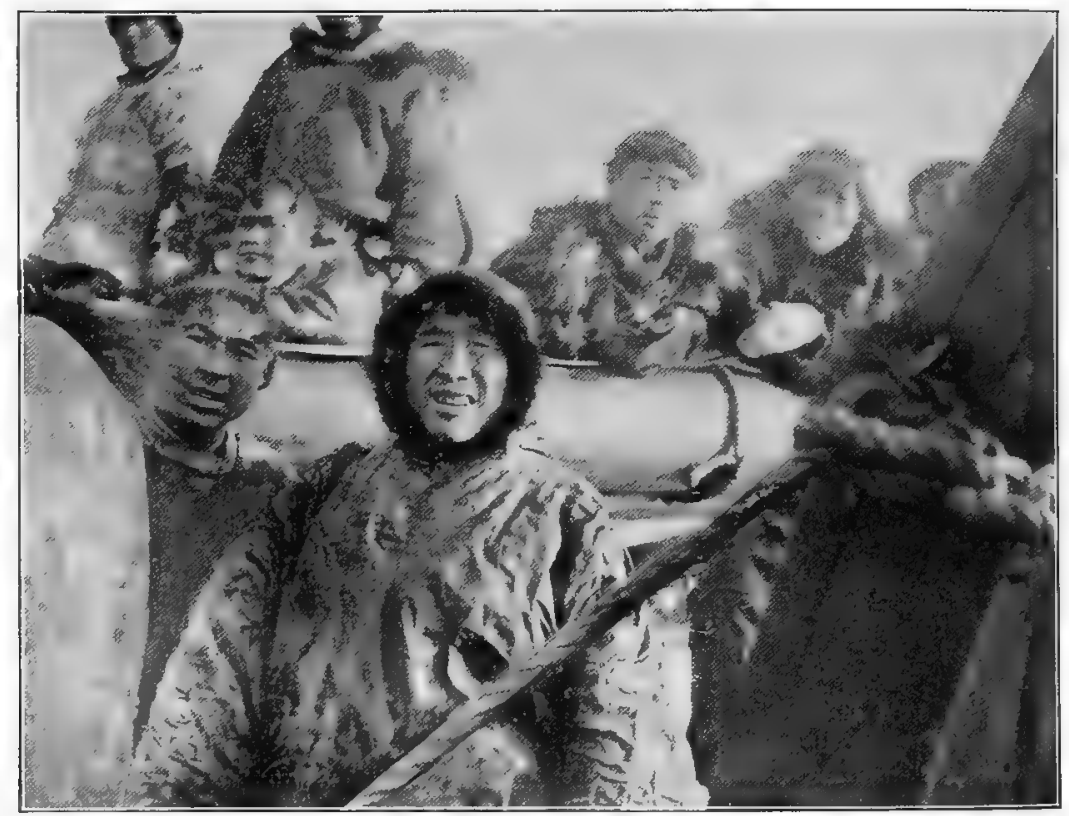

SIUERIAN CHAPLIN. NATINESAT CAPE, 
covered with snow. Toward the southeast the bluish white rocks, known as the Diomede Islands, were sharply outlined against the sunlit masses of vapor which concealed the American coast from view.

On leaving the cape our course was shaped for Cape Tchaplin, or Indian Point, as it is known among the whalers, situated a hundred miles farther down the Asiatic coast. We reached the Point on the morning of the IIth, and spent the day anchored off the long low sandspit, upon which the settlement stands, engaged in trading for whalebone and walrus ivory with the natives, who came aboard in such numbers as to fill the cabin and cover the decks.

Their chief, Gohara, was among their number. He was a dignified and intelligent looking man and had little to say, even in trading. He is said to possess a herd of reindeer, whaleboats and trading goods amounting in all-valued at San Francisco prices-to fifty thousand dollars.

Considerable quantities of alcohol and other liquors have been distributed among these people, though the nefarious traffic is now about suppressed. The natives have been "educated" until they are nearly a match for the whisky trader. The chief will no longer buy a demijohn of alcohol without testing it from the bottom. He remembers the time when he drank the first draft from the vessel and became very "molly kelly"-drunk, while his followers quenched their own overpowering thirst with the water on which a pint of alcohol had been carefully poured. Captain Murray told me that he had once purchased two bundles of whalebone, of a native of that coast, in which two heavy iron bars were concealed. When the trick was discovered, the thrifty Eskimo laughed and said, "alle same white man!"

An unusually large and handsome polar bearskin was brought on board which had been dressed in such a manner that it could be mounted. This I succeeded in purchasing for the University.

We set sail in the evening with a fair wind which carried us across Behring Sea in four days. The Aleutian, or Fox, Islands as they are known to the whalers, were passed on the I $4^{\text {th }}$ of October. The volcanic peaks on either hand were obscured by snow squalls until we were fairly within the pass of Unimak, when the clouds lifted sufficiently to reveal the sterile and forbidding coasts. 
The waters of the Pacific were noticeably darker than those of the shallow, muddy seas which we had left. The officers took great pleasure in relating yarns describing incredible achievements in arctic navigation, especially in the presence of the Count, who was an experienced navigator, and who had no patience with the rule-of-thumb methods of many of the old whaling captains. For example, "there was old Captain Silas $\mathrm{B}$ _ who, when he left the whaling ground, headed straight for the American coast, from this he shaped his course for Behring Straits. When he decided by the log that he had passed this, if the thick weather or darkness obscured the land, he steered for "seventy-two" (Amukta) Pass and, if he sighted no land there, he turned toward San Francisco as soon as he struck blue water!"

The run of two thousand miles to the Golden Gate was a stormy one. During one of the gales the order to "heave to" came too late, and one of the quarter boats was swept away as if it had been held by pack thread instead of lashed as securely as hemp could hold it. There was no place for me to sleep except on the cabin sofa which extended athwart ships. If I was awakened during the night and found my heels two feet higher than my head, to which the blood had rushed, I knew that we were sailing on the other tack! When the ship came about I had to tack also. The vessel was very small and the North Pacific, or the Arctic itself, in October, has no mercy on such craft. The mal de mer claimed both the Count and myself for its own. The change from the simple diet and active life of the northern voyageur to the more palatable though less wholesome food, and the confinement on shipboard for two months, greatly reduced our strength.

When the weather permitted, the crew was employed in washing and bundling whalebone. The crow's nest was taken down, and the top-gallant and royal yards returned to their proper place which the lookout box had occupied while the vessel had been in Arctic seas.

Day by day the temperature rose, until the 26 th, which was the warmest experienced that year. On that day the worn fur garments of both officers and men went over the rail, and creased and wrinkled clothing which had been packed away for twenty months was substituted. 
We entered the harbor of San Francisco early on the 27th of October. The morning sun rose from behind the eastern mountains upon a scene of beauty which to our eyes, so long accustomed to snow and ice fields, seemed like a glimpse of heaven. On either side of the narrow entrance the rugged hills rose abruptly from the water's edge where the heavy ground swell broke in long lines of sparkling foam against the dark cliffs. How different the green hillsides, dotted with trees, viewed through the balmy air of a perfect day, from the barren, fog-enveloped, and snow-covered mountains of the Aleutian Islands which we had passed twelve days before!

We were landed too late in the day for me to transact any business so that I could not leave for the east until the following Monday, and even then the ferry gates were closing as I rushed through to board the Oakland boat.

As I neared Iowa City on the 2 nd of November, I received a score of congratulatory telegrams from friends and organizations, which somewhat prepared me for the flattering reception by the faculty, students, and citizens, to the number of several hundred, who met me at the railway station. 


\section{CHAPTER IX}

\section{THE NORTHERN ATHABASCANS}

THE Athabascan family is separated, geographically, into 1 three primary groups: Northern, Pacific, Southern.

The Northern group includes the tribes inhabiting the region which is bounded by the narrow territory of the Eskimos on the north and east; by the Churchill River and Lake Athabasca on the south; and on the west by coast tribes of other stocks. They occupy nearly the whole of the interior of Alaska, and reach the coast at Cook's Inlet and at Copper River. The Pacific group includes a number of tribes in Washington, Oregon and California, the names of which are not widely known. The Southern group embraces the Navajo, Apache, and Lipan tribes.

The best description of the Northern Athabascans is that given by Samuel Hearne, who crossed their territory, without flourish of trumpets, in 177I-2. This officer of the Hudson's Bay Company was the first explorer who reached "The Frozen Ocean," north of this continent, overland. ${ }^{1}$ His excellent description of the natives acquaints us with their character before it had been modified by contact; it shows us that there has been little change in their condition during the century and a quarter which has since elapsed.

At present I can offer only a few observations regarding these people, with whom I was hardly in sympathy when I was with them. They did not wish to see mountable specimens of the caribou and musk-ox taken out of the country, ${ }^{2}$ and as I did not attempt to buy their good will I did not obtain it, except in a few instances. During the three years which have passed since my residence among the Dog Ribs, I believe that

1 See p. I32, ante.

- See p. $7 \mathrm{I}$, ante. 
I have come to have a better understanding of the "Indian mind." They were more intelligent than I supposed, but I made the mistake of judging them by our standards, and my first impression was followed by disappointment. They occupy what Professor Mason terms the "birch-bark region;" 1 the few and extremely primitive arts of which, apparently, have not advanced their mental development. They were never stupid, but always light hearted, even under the most depressing circumstances. Twice, while at the edge of Barren Ground, the whole band was without food, and the caribou were scarce; the men gathered in one of the largest lodges to consider the situation and to form plans for remedying it. One of their number began the discussion by cleverly mimicking the speech of an absent chief. They closed their by no means solemn deliberations by singing a number of native songs, notwithstanding their very empty stomachs.

I several times saw the men pick up spruce sticks and, after cutting down one side until they had a smooth white surface, mark on them in charcoal in the syllabic character; the others present would then try to imitate the first, but the "copy" was soon thrown aside. Indeed the children are now taught to read and write by the Roman Catholic missionary at Rae and both men and women can read their prayer books readily. ${ }^{2}$ But the use of denotive symbols has not yet affected their mode of thought. Their ideas are not capitalized, so to say, by recorded language. ${ }^{3}$

The women always occupied the coldest place at the camp fire-that next the entrance to the lodge. They performed the labor of making and caring for the camp and of dressing skins, the latter no inconsiderable task, as nearly everything made and used by these people is of caribouskin or birch. The women did not often cut the firewood or haul in the game which the men killed. This work was almost always done by the children.

A harmless lunatic, who wandered about the camp with star-

1 American Anthropologist,Vol. VI, p. I5I.

- See $\mathrm{p} 3 \mathrm{r}$, ante.

8 "Chose admirable, ces hommes de la nature ou des dispositions naturelles qui leur permettent de saisir promptement ce qu'on leur enseigne: en moins de trois semaines un grand nombre savaient lire et écrire." Farand, Henri, Dix-huit ans chez les Sauvages, Paris, I866, p. 89. 
ing eyes and dishevelled hair, was always greeted with jeers. A hunchback, of apparently vicious disposition, was silently ignored, though he seemed to be in fear of even the boys.

Population. The officers of the company, of whom I inquired concerning the Indian population, were of the opinion that the number of inhabitants had not materially changed during the past twenty years.

I am indebted to Mr. J. S. Camsell for the following census which was prepared for the Canadian Government.

\section{Population of the Mackenzie River District.} MEN. WOMEN. BOYS. GIRLS. TOTAL. JUne' 81 . 1858 .

\begin{tabular}{|c|c|c|c|c|c|c|c|c|c|c|}
\hline Rampart $\mathrm{Hou}$ & se, & & • & . 37 & 39 & 39 & 49 & 164 & 286 & \\
\hline La Pierre's H & lou & & & . $3^{2}$ & 39 & 49 & 48 & 168 & 286 & \\
\hline McPherson, & . & - & * & · 99 & 107 & I 38 & I I I & 455 & $35 \mathrm{I}$ & 337 \\
\hline Good Hope, & . & . & • & .162 & I 57 & 97 & I3I & 547 & $5^{8} 3$ & $4^{6} 7$ \\
\hline Norman,. . & - & . & . & . 86 & 74 & 82 & 82 & $3^{2} 4$ & 254 & $3^{63}$ \\
\hline Wrigley,. & . & . & . & - 36 & 39 & $5^{8}$ & $3^{I}$ & $164\}$ & 500 & \\
\hline Simpson, & 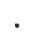 & . & . & . 74 & 76 & 45 & 39 & $234\}$ & 500 & 745 \\
\hline Liard, . & 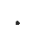 & . & - & - 70 & 54 & 53 & $4^{2}$ & 219 & $216\}$ & 397 \\
\hline Nelson, & $\cdot$ & . & - & - 54 & 54 & 66 & 50 & 224 & $209\}$ & \\
\hline Providence, & $\cdot$ & & . & 90 & 90 & I39 & I 17 & $43^{6}$ & $45^{6}$ & \\
\hline Rae, . . & · & . & $\cdot$ & - I68 & 188 & I 76 & 179 & 711 & 615 & 657 \\
\hline & & & & 708 & 917 & $94^{2}$ & 879 & 3646 & 851 & 56 \\
\hline
\end{tabular}

It will be seen that this vast area is but thinly populated. It is not probable that their relations with the traders will have any material effect upon their numbers. The inhabitants of the trading stations during the winter of '93-'94 were upon the verge of starvation themselves, and certainly could not have relieved the natives in case of famine. The use of improved firearms insures the extermination of the game birds and mammals of the country, so that the ultimate destiny of the Northern Athabascans is to become fishermen.

Lodges. The caribouskin lodge ${ }^{1}$ is supported by a framework of twelve to thirty poles. In pitching camp in winter, sticks are thrust through the snow in order to find solid earth for a floor; if the stick enters soft moss the place is avoided, as the camp fire would spread and undermine the lodge. When a suitable site is found the men clear away the snow with their

1 See p. 25, ante. 
snow-shoes and perhaps assist the women in cutting and carrying the lodge-poles. It is the women's duty to carry bundles of spruce boughs with which to cover the floor of the lodge. The brush is laid carefully, branch by branch, so that the stems are under the tops and point away from the center. This floor is renewed every Saturday afternoon. The fireplace is surrounded by a pole of green wood, three or four inches in diameter, cut so as to be bent in the form of a polygon. Above the doorway a pole eight feet long is lashed to the lodge-poles in a horizontal position, six feet from the ground; this, and a similar one on the opposite side, supports from six to ten poles, crossing above the fire, making a stage on which to thaw and dry meat. Each hunter's powder-horn and shot-pouch is suspended from a lodge-pole at his back, his gun stands in its cover against a pole or lies on a stage outside. Near the doorflap are several hungry and watchful dogs, which, by constantly running in and out, make an opening for the cold wind to enter. The dogs are tied at night to prevent their pilfering; one end of a stick, three feet long, is tied to a lodge-pole, the other end is provided with a thong long enough to pass around the dog's neck; this manner of fastening prevents them from gnawing the line and setting themselves free. The side of the fire next the entrance is allotted to the children and visiting women. On either side sit the wives, for there are usually two families in one lodge. Behind them are muskimoots and an inextricable confusion of rags, blankets, bones, meat, etc. If a crooked knife, a tea bag, or anything that is in the heap is needed, everything is tumbled about until it is found; nothing seems ever to be lost. The sled wrapper is extended behind the lodge-poles and serves as a catch-all for stores of meat, bones to be pounded and boiled to extract the grease, and odds and ends not in constant use. The next space is occupied by the men of the house, that farthest from the door is reserved for the young men and the men guests. At night each adult rolls up in a single three-point blanket, or a caribouskin robe, and sleeps on an undressed caribouskin. A piece of an old blanket generally covers the small children in a bunch.

Migration. The natives dependent upon the Barren Ground caribou for subsistence, not only follow them in their annual migrations, but are changing their hunting ground in conse- 
quence of the general eastward movement of the game. The Slaveys, who formerly killed large numbers of caribou between the Mackenzie and Rae, are now compelled to live principally upon fish, and when these fail, as they did during the winter that I spent in the country, they are reduced to actual starvation. The score or two of Slaveys whom I saw at Providence were dirty, thievish and poverty stricken.

The recently established trade in robes has caused the muskox to be driven out into the Barren Ground until they are almost beyond the reach of the Dog Ribs. Several bands of this tribe have therefore moved along the lake shore, into and beyond the territory occupied by the Yellow Knives.

The disappearance of the caribou from the neighborhood of Good Hope and Norman has caused the Indians to withdraw to a greater distance from the trading stations, and a few, such as Naohmby, have encroached upon the Dog Rib hunting grounds. An Indian made his appearance at Rae on the first of February who had attended the Christmas feast at Norman. $\mathrm{He}$ had come by the way of the Great Bear and Marten Lakes.

The various bands seem to be more restricted in their movements than before the advent of the traders, if we may judge by the accounts of Hearne. This is due to their intercourse with the traders, to whom they are always bound by "debt," and especially to the influence of the missionaries.

Religion. Nearly all the Indians of Mackenzie District are nominally christians. The Trout Lake, numbering forty hunters, and some other Western Indians still adhere to the faith of their fathers, whatever that may have been. Those professing christianity are either Episcopalians or Roman Catholics. The Dog Ribs are very strict in their observance of the outward forms of the Catholic Church. No meal was ever eaten in my presence, during a two months' residence among them, without grace being repeated in concert, and it sometimes required a strong effort of the imagination to see anything to be thankful for. The Sunday services were very ceremonious functions which always terminated in a feast when in camp. If traveling, prayers were said before the day's journey was begun. They displayed heroic faith when they knelt in the snows of the Barren Ground to offer up prayers with chattering teeth, shifting their rosaries with half frozen fingers. In their hymn and 
prayer books they carried from one to a dozen cards and photographs which, even if they were all exactly alike, were carefully spread out upon the blanket before their possessor before the service began.

One effect of the introduction of christianity has been to abolish polygamy. I heard of but one Dog Rib-rejoicing under the euphonious name of Buggins-who had more than one wife. Several women are said to have been left to die of starvation as the result of the too abrupt introduction of the new order of things.

Many of the old superstitions still obtain. When moving our camp at the edge of the Barren Ground, a two days' trip, two of the young women were forced to break new tracks with their snow-shoes in the soft deep snow, several yards from the trail. How such a senseless and cruel custom could have arisen, much less be perpetuated under the eyes of the missionaries, it is difficult to understand, as the monthly recurrence of their condition causes a great deal of unnecessary hardship, owing to their journeys in the pursuit of caribou.

Provision. The Company's posts are built upon the shores of the lakes and rivers at points where fish may be obtained in large numbers. Only sufficient flour is imported to allow the officer in charge and his family from two to four hundred pounds, and the engaged servant but one hundred pounds, a year. Dried fish or dried caribou ribs are kept for the use of the men while traveling, and frequently as the regular ration when the fishery fails. Fresh meat is the most desirable provision, for which the Indian receives a fair price. Pounded meat, grease (marrow, tallow and bone grease), tongues, beaver tails and moose muffles, are not traded so much as formerly. The Indians say, when questioned, "You do not give us your good things, so we will eat our choice food ourselves." While at the Dog Rib camps at the edge of the Barren Ground, I saw large quantities of pounded meat, grease, and tongues eaten, and all was hospitably shared with me, yet they refused to sell any of these luxuries if carried away from the camp. Though they were offered a high price, they did not bring onefourth of the grease needed at Rae during the winter of I893-4. The Indians when visiting the trading stations are lodged in the cabins of the métis servants, to whom they bring considerable 
quantities of their best provision, "to show how well the Indian lives."

Syrup. A very inferior quality of syrup is made at many posts from birch sap. I found but one entry in the Rae journal regarding the date,-May 20th, I885, "Syrup makers off to gather sap." The camp is about three miles east of the station; the sap is collected in birch rogans which are made on the spot and kept there en cache during the winter.

Leaders. Hearne's remarks regarding the influence of the chiefs of the Northwest Indians of a hundred and twenty years ago, are equally true today: "It is an universal practice with the Indian leaders, both Northern and Southern (Athabascan and Cree), when going to the Company's Factory, to use their influence and interest in canvassing for companions; as they find by experience that a large gang gains them much respect. Indeed, the generality of Europeans who reside in those parts, being utterly unacquainted with the manners and customs of the Indians, have conceived so high an opinion of those leaders, and their authority, as to imagine that all who accompany them on those occasions are entirely devoted to their service and command all the year; but this is so far from being the case, that the authority of those great men, when absent from the Company's Factory, never extends beyond their own family; and the trifling respect shown them by their countrymen, during their residence at the factory, proceeds from motives of interest." 1

The first camp to which I went with Johnnie Cohoyla contained forty men but no leaders. They were to engage in the musk-ox hunt in small bands, and that being the greatest commercial venture of the year would, it might be presumed, cause them to accompany their chiefs upon the hunt. Yet when "Jimmie the Chief" visited the camp, seeking to induce more hunters to join his party, but two men would accompany him, making but ten in all, with the most respected of the Dog Rib leaders.

Still the chiefs themselves strive to increase their prestige; the gratuities from the traders are liberally shared with their followers, and the most eloquent begging is kept up as long as they remain at the post. None but a successful hunter need aspire to the hand of a chief's daughter. Mr. Hodgson, being

${ }^{1}$ Hearne, Fourney, p. 288. 
desirous of obtaining a musk-ox's head, asked a Dog Rib, whom he had heard was a good hunter, if he could kill a caribou. The Indian, not understanding the humor of his question, did not deign to reply. "Do you think you could kill a musk-ox?" Drawing himself up he replied, "You do not seem to know me. I married the daughter of the chief Rebesca."

The principal Dog Rib leaders at Rae were Jimmie, Rebesca, and Naohmby, while Beniah, Little Crapeau, Dry Geese, and Castor traded at Resolution, to which the Yellow Knives also resorted under the leadership of Zinto, Zyena, Black Head and others.

Language. When at Rae, I prepared a list of six hundred words of which I wrote, phonetically, the Dog Rib equivalent, as interpreted by Henry Cadien, a métis freeman, who had been at one time the fort interpreter. It is an exceedingly difficult language to express with the Roman characters; nasals and aspirates abound; when separated I could easily indicate the proper sound, but combined, and with a burring $\mathrm{R}$ added, I found difficulty in pronouncing and still greater difficulty in writing the sounds. At Providence, Joseph Bouviar, the post interpreter, translated the same list into Slavey. Kenneth Stewart, a Scotch métis at McPherson, acted as interpreter in preparing a Loucheux vocabulary. Owing to so many sources of error in their preparation, notwithstanding the time and care bestowed upon them, I prefer to defer the publication of these vocabularies in the hope that I will have opportunity to again visit the country where the dialects are spoken.

Calendar. From the missionaries the Dog Ribs now obtain slips of paper on which the days are marked in vertical lines, and every seventh day with a cross. The days are pricked off as they pass, with a needle, on this primitive calendar, which is in the keeping of their leaders. They differ among themselves as to the names applied to the months.

$\begin{array}{lll}\text { January, } & \text { Ét-se să } & \text { Cold sun. } \\ \text { February, } & \text { Nitt-se să } & \text { Small wind sun. } \\ \text { March, } & \text { Nit-se-chă să } & \text { Big wind sun. } \\ \text { April, } & \text { Win-di-thi-che-ko să When the dogs travel with tails }\end{array}$

1 We travel far between sleeps in the spring when the days are long and the dogs go well. 
May, Ne-wik-ŭn să

June, Wen-ă-kĭ să

July, Wĕn-a-chy-kon să

August, Wĕn-ăt să

[or]

Wěn-di-e-inn-e-ti să

September, Wĕn-ă chă să

October, Ěk-olă-chĭn-co să

November, Wĕn-de-ton ${ }^{\mathrm{n}}$ să

December,
Sore eyes sun.

Egg sun.

When the wing feathers are moulted sun.

When the caribou enter the woods sun.

When the berries are ripe sun.

When the caribou are abundant in the woods sun.

Paddle shoulder sun.

(Alluding to the practice of striking a scapula against trees in luring moose at this season.)

When the ice sets fast sun.

SLAVEY NAMES OF THE MONTHS.

January, E-toz-in-e-cho-ke să

February, Ni-tsyă să

March, Tĕ-to ${ }^{\mathfrak{n}}$ sho să

April, Ni-tsyă-cho să

May, Be-ken-ot-o-to-ni-non-ta să

June, Chi-mĕ-ăb-ě-ya să

July, Bĕk-kĕ-chi-ě-yă-tĕn-nĕ-ť să

August, $\quad$ Colon-ye-kĕn-ak-e-ne-i-a- să

September,

October, Thlu-ǐ-kă-tse-de-tĭ să

November,

December,

DOG RIB.

\section{2 , Tän-dizĕ}

$I, \quad$ In-klai-1

2, Nă-kì

3, Tă-1

4, Ding

5. Sind-lă-ì

6, $\left\{\begin{array}{l}\mathrm{U}^{\mathrm{n}} \text {-ke-ton } \\ \text { Ekk-e-tă-i }\end{array}\right.$

7. $\quad \breve{t} t-\breve{a ̆}^{n} d \breve{i}^{n} g$

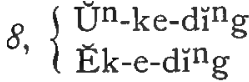

NUMERALS.

SLAVEY.

Be-ki-zin

The-i-gă

Ǔn-kĕ

Tă-yĕ

Tin-ghĕ

Să-sŭnd-lă-ĕ

Tsinn-tă-ĕ

Thănt-tìng

Ět-sand-ting
New-year's sun.

Small wind sun.

Eagle sun.

Big wind sun.

The geese arrive sun.

Ducks are laying sun.

Berries ripen sun.

Moose rutting sun.

Fishery sun.
LOUCHEUX.

Tĕn-jer.

İq-lŭk.

Nă-kĭg.

Ti-äk.

Tän-kŭ.

Klo-hŭn-dě.

Nì-kĭ-tŭk.

Dĭt-zì-hă-tsi-ne-kì

Nǐk-ĕ-tan 
DOG RIB.

SLAVEY.

LOUCHEUX.

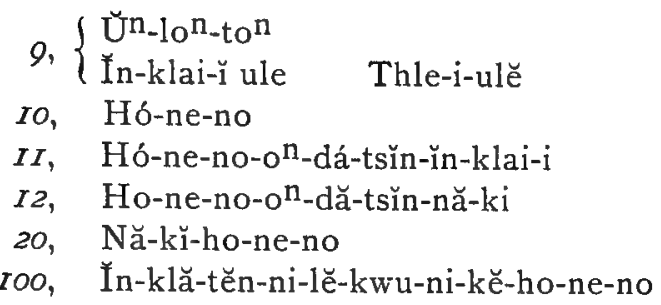

Uัn-trŭn-to-kwă.

GEOGRAPHICAL.

DOG RIB.

Willow River, near Rae, Kai-i-tă-ni Te

Jackfish River, near Rae, Ǔn-te Te

Coppermine River,

Yellow Knife River,

Tson $\mathrm{Te}$

White Rock River,

Be-vwu-lĕ Te

Jackfish Lake,

Little Jackfish Lake,

Kwĕm-be Te

Ǔn-tă-kă Tu'

Marten Lake,

Unn-te-ĕ Tu'

Bear's Shoulder Lake,

Son Tu'

Rae,

Să-kon-ton Tu'

Nì-cĕ-ku'

Providence,

Yă-tı̆

Resolution,

Tĕn-ni-du-ă

Simpson,

Eth-i-tlin-ku'

Smith,

Chippereyan,

Kwĕm-bă-chă

Kă-ĭ-te-ku ${ }^{n}$

Island Hill Post. Priests.

Moose Island. The Forks Post. Big Rapids. Willow Ground.

SLAVex.

MackenzieRiver, ${ }^{1}$ Tĕn-di-ci-cho

Slave River, Tendoykua-cotega tendethy

Peace River, Tsă-o-ti ni

McPherson, Tă-tlă-ku End of the World Post.

Good Hope Kă-tco-o-ti-ne ku Arctic Hare Indian Post.

Norman, Să-tco-tu-e-ku Big Bear Lake Post.

Liard, A-tco-tĕn-ku Trout Lake Indian Post.

McMurray, Tĕ-tco-ku Rapids Post.

1 Compare Petitot, "Carte," etc. In the Dialect of the Providence Slaveys, Dis-nedhe-yare. The Wrigley Slaveys, T'i-kka. The Hares, Nakotsia-kotcho. The Loucheux, Nakocho-ondyiz. 


\section{CHAPTER X}

\section{ETHNOLOGICAL MATERIAL SECURED IN THE HUDSON'S BAY COMPANY'S TERRITORY}

THIS list includes several specimens not made by the In1 dians, but all of which are typical of those used in the Fur Country, exclusive of the northern border where the Eskimos have arts peculiar to themselves. With the exception of the deservedly much-praised birch-bark canoe and the birch flat sled, it is believed that every article ${ }^{1}$ of Dog Rib manufacture, of any consequence, is included in this list. They use gill nets, unrepresented in the collection, but they are made by the women after the manner taught them by the métis voyageurs. They are almost without arts, and lead a wandering life which prevents the accumulation of any considerable amount of property. One industry, at least, that of dressing skins, has been fairly well developed, as naturally might be expected in a country where so many skins are absolutely necessary for their protection.

Caribouskin Lodge. The collection contains a skin lodge from Rae, which was made for the chief Naohmby. It is made from the dressed skins of forty caribou. It is 13 feet in circumference at the top and 57 feet at the bottom. It is 12 feet from the top to the base. When carried it is rolled in two rolls so that the middle, opposite the open side, may receive a pole in the loop at the top with which to raise the rolls in position against the cone around which they are unrolled in setting up the lodge. The free edges overlap and are made fast by thongs 4 feet long. The two wings at the margin of the smoke hole are shifted, according to the direction of the wind, by two poles resting against the outside of the lodge. It is much easier to enter a Cree lodge than to scramble into that of the

${ }^{1} \mathrm{~A}$ dog harness, a general description of which is given in the narrative, p. 16 , is included in the collection. 
Dog Rib, through the opening made by lifting the lower edge at the point where the sides meet. The two circular seams are usually marked by a red ochre band, an inch wide. The upper part of the lodge is soon blackened by smoke and soot. Besides the opening at the top, 3 feet in diameter, ventilation is secured by means of the innumerable grub holes with which the skins are perforated.

Clothing. The adoption of the costume of civilized man has not been a hygienic success. The women wear light print dresses which are a poor substitute for the warm skin clothing of former times. A few gowns of dressed leather are still worn by the Dog Rib women, and both sexes wear capotes of caribouskin in the hair while traveling in winter.

Nearly all children under ten years of age are insufficiently clothed. I saw Dog Rib urchins in midwinter playing outside the lodges or gathering fuel while literally half naked. The younger ones frequently complained, though the older ones seemed as happy and contented as those of warmer climates. The young men are more fastidious in the matter of dress, and wear more beads, quills, silk, and feathers than do the young women, and, I may add, are more cleanly. The Northern Indians are neither so well clothed nor so well housed as are the Eskimos; the latter manufacture waterproof boots and frocks while the former have no form of foot wear except the moccasin which is wet at all seasons; and from the rain they have no protection whatever.

Hunting Frocks. These are common among the Crees and Athabascans. They are also worn by the métis, by whom they are elaborately decorated with porcupine quills, ribbons, beads, and silk embroidery. There is a mooseskin frock, No. I0,914, in the collection, from McPherson, which was made by a Loucheux woman. It is short in the skirt and sleeves and broad across the shoulders. There are two pairs of thongs, at the throat and breast, by which it may be closed; it broadly overlaps at the waist where it is confined by the belt. The front is hemmed with black cotton cloth backed by a narrow red ribbon. The shoulders are occupied by epaulets of black and green cloth, with a margin of caribou leather fringe whipped at the base with red and purple porcupine quills. The fringe encircles the arms at the shoulder and extends across the back. The sleeve has a 
single button at the wrist. This frock is 32 inches long, 26 inches across the shoulders, 54 around the waist, and 20 around the neck. The sleeve is $2 \mathrm{I}$ inches long. It has been worn and, owing to the method of tanning, has a strong smoky odor.

Leather Gown. The collection contains but one, No. I0,850, which was worn by a Dog Rib woman, the wife of Johnnie Cohoyla. It is of dressed caribou leather made up in a polonaise. The only cloth used is in the belt, I.5 inches wide, and a velvet hem 0.5 in width. It is closed in front by a pair of thongs at the throat and by three brass trousers buttons at the waist. It is 48 inches long and I 3 inches across the shoulders. The sleeves are 16 inches long. It is sewed with sinew and has many rents and patches. It has been long worn and is covered with dirt and grease. The skins of five caribou were used in making it.

Capotes. The men of the Dog Rib tribe wear capotes of caribouskin, dressed with the hair on. These are usually made from the skins of animals killed in early autumn, when the soft summer pelage is at its best. No. 10,853, of winter caribouskin, a typical specimen, was made for use upon the musk-ox hunt. It is large enough to be worn over another capote by a man of average size. The skins of three caribou were used in making it; the largest one forms the back and hood; a second, cut in halves, forms the sides, and the third the sleeves and front of the hood; this last is a piece 3.5 inches wide at the top and tapers to a point 26 inches below, the ends hanging free for Io inches below the chin; it is double, the inner piece being turned with hair inward to protect the face. This is the only lining about the garment, and I know from experience that the bare leather soon becomes cold and disagreeable against the neck and face in severe weather. This capote is 3 feet long with a $2 \mathrm{I}$ inch sleeve. It is closed by two pairs of thongs and by the belt.

Caps. North of Athabasca Landing the usual head covering of the Indian is his heavy hair, confined by a bandana handkerchief in summer, which has replaced the hair or deerskin headband of the past, or by the hood of his capote in winter. A few wear hats obtained from the traders and others a "birch cap" of their own manufacture. I obtained one of these caps from a Cree at Chippewyan. It is made of a band of birchwood 2.5 inches wide and 7.5 inches in diameter. It is covered 
with coarse woolen cloth and lined with print. The sides are ornamented with beads upon a background of dark red ribbon. There are several black bead stars on the top to which is attached, by a string 2 inches long, the figure of an animal cut from heavy tin. Loosely tied around the outside is a piece of cheesecloth intended to be drawn over the eyes to prevent snowblindness in spring. The wearer had used the crown for a needle case. When at the Narrows of the Saskatchewan I obtained a boy's cap, No. 9,608, made of the skins from the necks of five loons (Urinator imber). It is lined with a piece of white cotton cloth. Its owner was greatly pleased at receiving a common cloth cap for it from the store.

Leggins. These are worn at all seasons by the métis and Indian women and by the men in winter. The collection contains a pair of women's leggins, No. 10,897, from McPherson. Like nearly all others of that country, they are of blue strouding and are ornamented by a double row of white beads at the bottom and a zigzag pattern in blue beads above it. There is a quarter inch hem of black cloth around the bottom and extending half way up the outer side. They are I 4 inches long and 8 inches broad to the seam, which is 2 inches from the margin. There is also a pair of men's short leggins, No. 9,609, from Isle à la Crosse. The beaded portion on the outside of the leg extends nearly the whole length of the leggin. It is of black broadcloth, nearly covered with beads in flower patterns, and surrounded by a quarter inch hem of pale blue ribbon. There are four tufts of narrow colored ribbons at the sides. The piece is 14 inches long and 5 wide. The leggin is of navy blue flannel, with a drawing-string of print at the top; it is 14 inches long and 8.25 wide. A pair of garters, 17 inches long and 2.5 wide, was worn with these leggins. They are also braided and have a rosette and lines and tassels at the ends of variegated worsted. The typical men's leggins reach above the knee and are fastened by leather thongs to the belt. They are sometimes made of white strouds with a scarlet stripe along the outer seam, but usually they are blue with the gray selvage at the top, and have a narrow braided piece along the outer seam below the knee. A pair of these pieces of beadwork, No. I0,898, from Good Hope, are of black velvet nearly covered with beads. They are 12 inches long and 3.25 wide. 
Moccasins. These are worn by all of the métis and Indians of the North; the whites in the country soon become accustomed to their use and are loth to return to the hard and cramping "English shoes." They are all made after the same general pattern; a single piece around the foot, a semi-elliptical more or less ornamented piece over the instep, and a top of light leather or canvas which folds around the ankle. They are fastened by a pair of leather strings which draw around the heel and pass two or three times around the ankle. Dressed moose leather is the best material obtainable by the Northern Indians for the manufacture of moccasins; caribou leather is also used, especially by the inhabitants of the caribou country, where few moose are to be found. The moccasin is certainly the best form of foot wear for use in the fragile birch canoe or for walking upon snow-shoes. But it is not a perfect protection for the foot, as the soft and flexible mooseskin will admit water as readily as blotting paper, and then wear away rapidly and stretch immoderately. Four or five pairs a day are sometimes required in tracking, and in spring traveling they are soon cut to pieces by the ice, though they are sometimes protected by a sole made from the skin of a caribou's leg with the hair on. They are sewed with sinew thread, which is strong and durable.

The collection contains a pair of moccasins, No. 10,835, of caribou leather, which were made for use upon the musk-ox hunt of the Dog Ribs in I894. They are quite large, to admit double blanket foot wrappings. The central piece is of scarlet cloth without embroidery and bordered with narrow blue and yellow tape. The top is of an inferior quality of leather.

I obtained a pair of slippers, No. I0,887, at McPherson, which are of heavy moose leather smoked a dark brown. The central piece is of blue strouding ornamented with a simple pattern in beads and bordered with two rows of horsehair colored blue and yellow. Around the tops is a strip of strouding, I.5 inches wide, free at the lower edge which is crenulated. These were made after a métis pattern by the wife of the Eskimo interpreter.

There is a pair of "silk-worked moccasins," No. 9,597, in the collection from Grand Rapids, which is an excellent example of métis art. The tops are of woodland caribouskin with a I inch piece of white-tanned Barren Ground caribouskin inserted 
in the seam. This is a common pattern, the insertion being frequently a piece of bright colored cloth, variously toothed or crenated at the free margin. The central piece is of white leather embroidered with silk in a floral design. Around this is sewn a four-ply braid of red and purple porcupine quills, bordered with one roll of light red and two of aster-purple colored horsehair. They are exactly alike but are worn as rights and lefts, the flexible leather adapting itself to the foot on the first wearing.

The collection contains a pair, No. II,229, from Macleod, made by a Piegan woman, which is of a different type. They are of cowhide with canvas tops and strings. They are made as rights and lefts. The soles are in two pieces. Along the middle of the instep and the outer margin of the upper there are a large number of beads arranged in geometrical patterns. There is a double fringe of red and blue flannel around the tops.

Duffels. The Indians wear pieces of blanketing for socks, but they sometimes obtain the loose, heavy woolen cloth known as duffel. The fibre is straight and coarse, but the loose texture makes it more suitable than blanketing for socks, mittens, etc. The whites and métis use it exclusively. A pair of duffels in the collection, No. 9,592, from Grand Rapids, are made in a single piece sewed around one side and at the heel. There is a broad tongue and no top, though this is usually made similar to that of a moccasin. The Indians and poorer class of métis tear the cloth in pieces a foot square and do not sew them at all. This form of foot wrapping has the advantage that the points of greatest wear may be shifted and the cloth does not become threadbare and cold so quickly.

Mittens. The Indians protect their hands by mittens of dressed leather lined with pieces of blanket, duffel, or rabbitskin and occasionally caribouskin with the hair inside. They are worn with a line around the neck to hold them when the hand is removed, as it frequently is in handling sled lines, dog harness, and in shooting. They are always large, loose fitting, and in severe weather afford insufficient protection. Those worn by the métis and whites are longer in the wrist, and ornamented with ribbons, silk, and beads, besides fur trimming and cords of variegated worsted. The collection contains a pair, No I0,834, from Rae, of moose leather lined with blanketing. They 
are 10 inches long by 6.5 broad. The thumb is 3 inches long and 3 broad. They are hemmed with a 2 inch piece of strouding at the wrist.

Sash. There is a beaded sash in the collection, No. 9,635, from Norway House. It is of black broadcloth, hemmed with green braid and lined with drilling. The beads are arranged in flower pattern, but with superior excellence and harmony of colors. It is 44.5 inches long and 2.6 wide. The ends are provided with two light thongs each.

Carrying Straps. The collection contains two of these from McPherson. They were made by métis women and are more elaborately ornamented than those used by the Indians. One of these, No. 10,900, is of caribouskin covered with black velvet, with a quarter inch hem of blue cotton cloth. It is ornamented with six rows of white beads and a central band of colored ones in alternate stars and circles. Along the lower margin are short strings of large beads terminating in worsted tags. The ends are furnished with brass belt fastenings obtained at the store. It is 44 inches long and 2.75 broad.

The other strap, No. I,090, is of mooseskin covered with blue strouding with a plaid margin. The beadwork is in flower patterns. The ends are provided with mooseskin thongs for tying. It is $4 \mathrm{I}$ inches long, 3.3 wide in the middle, tapering to 2 inches at the end.

Dog Shoes. These are used in lake travel, late in winter, when the sharp granular snow soon renders the dogs' feet raw and bleeding, or in spring when traveling upon the needle ice, after the snow has disappeared. The collection contains a half dozen shoes of caribouskin. They are simple bags, 8 inches deep, and 5 inches across, rounding at the bottom and having leather tying strings at the top. Common cloth, canvas or leather is used, but all wear out rapidly or fill with ice and cause so much suffering that many travelers discard them altogether.

Tobacco Pouches. Each of these contains flint, steel, touchwood, a small quantity of plug tobacco and a medium-sized pocket knife. The "fire bag" is usually made of fine cloth or velvet, ornamented with silk or beads. . The collection contains one, No. 10,888 , from McPherson, which is ornamented on both sides by beads in flower patterns. The top has a double drawing-string of worsted. This bag is 7 inches long and 6 broad. 


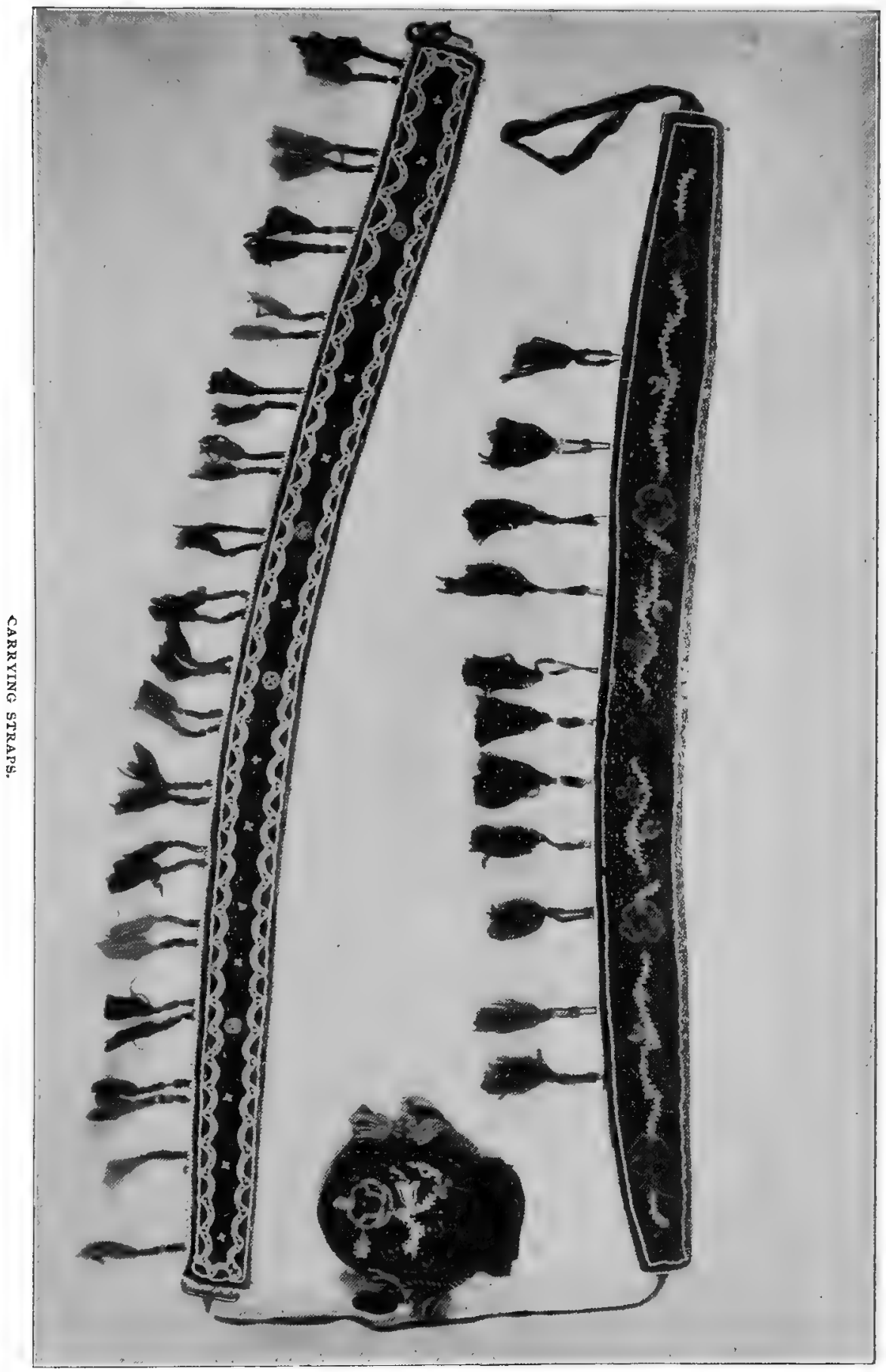



Another, No. 10,889, from the same locality, is of black velvet beaded upon both sides, closed by a silk drawing-string and further ornamented by a silk thread around the bottom.

Specimen No. I0,89I, is of a single swan's foot. There is a hem of cloth at the top, containing a drawing-string of threeply, braided wrapping twine. It is cloth lined and has been used. I obtained this pouch from Rat Indians visiting Herschel Island.

I obtained a fire bag, No. $9,6 \mathrm{I} \mathrm{r}$, which is very old and much worn, from an old Cree medicine man, on the Saskatchewan. It is of broadcloth with a narrow margin of green ribbon and white beads. The top is plain but the lower third of each side is beaded with flower patterns in startling color combinations. There is a closely clipped roll of variegated worsted at the bottom, from which hang worsted tassels at the ends of short thongs on each of which are strung three large blue beads. The open top is furnished with a short loop of three-ply, braided worsted, probably to hang it by when not in use, as it is then kept closed by being drawn under the belt. It is I I inches long and 5.5 broad.

Shot Pouches. The collection contains one, No. 9,634, which was made by a métis woman at Norway House. It is the best specimen of the imitative flower pattern beadwork that I saw in the North. It is of dark blue broadcloth with a sash 2.5 inches wide and 4 feet long, by which it was suspended so that the lower part of the pouch passed under the belt which prevented its contents from falling out and kept the pouch itself in place. It is 10.75 inches long in the back, 7.5 in the front and 6.5 broad. It is lined with light canvas. Both pouch and sash are heavily beaded.

Fire Steel. Flints and steels for striking fire are still supplied by the Company to the Northern Indians. Steels are commonly made by the natives from old files. I obtained a well made specimen, No. I I,006, from a Chippewyan at Resolution. It is rather heavier than common and has a short bit at the open end to be used as a screw-driver.

The flints are imported. A specimen, No. 9,639, in the collection, is a quadrilateral truncated pyramid, 1.25 inches long by I wide. For touchwood the Indians use the hard fungus from dead birch trees. They beg for matches at every oppor- 
tunity, as they do not enjoy the experience of striking fire for five minutes before getting the pipe alight, when the hands are exposed to a temperature of $70^{\circ}$ below zero.

Work Bags. There is one, No. 9,6I4, in the collection, from Chippewyan, that is rather unique in design. It is of the skin of four swan's feet, two on each side, with a one inch strip of mooseskin around the bottom. It is ornamented with tassels of worsted attached by thongs covered with quills and beads. It is 9 inches deep and ro broad.

Drum. The collection contains one drum, No, Io,829, from Rae. The frame is of birch wood, 0.5 of an inch in thickness, 2.I wide and 14 in diameter. The ends are scarfed together and lashed with babiche. It is provided with two babiche lines crossing each other at right angles by which it is held when in use. The head is of caribouskin parchment. It contains one grub hole and two cuts which have been sewed. It is fastened near the rear margin of the frame by babiche, which passes through holes which are in pairs at intervals of an inch and a half, and over a band passing around the head. There are three snares, two of twisted babiche, and a central one of thong. The head is tightened by heating. The stick, which I saw used for weeks before I obtained the drum, is a worm-eaten fir branch with a slight natural curve. The bark is partly removed, but the ends are broken and rough. It is 12 inches long and 0.5 in diameter.

Sinew. The thread used in sewing moccasins and most of the leather garments of the country is made from the broad sinews of the back of the caribou. This is dried and the fibres separated and twisted by the palm of the hand upon the knee until a thread is formed of convenient length for use. The rough sinew is usually carried and a small quantity of thread made as it is used, or it is made in quantity and kept loosely braided in plaits. A bundle of sinew, No. 9,636, in the collection from Grand Rapids, is of pale straw color. The threads are from 20 to 24 inches long and somewhat larger than coarse linen thread. One end tapers from about 6 inches to a fine point which is used in lieu of a bristle in sewing with an awl, a needle being seldom used. At present the only needles in the country are the ordinary imported glovers' needles.

Canoes. The collection contains but one model, No. 9,62I, 


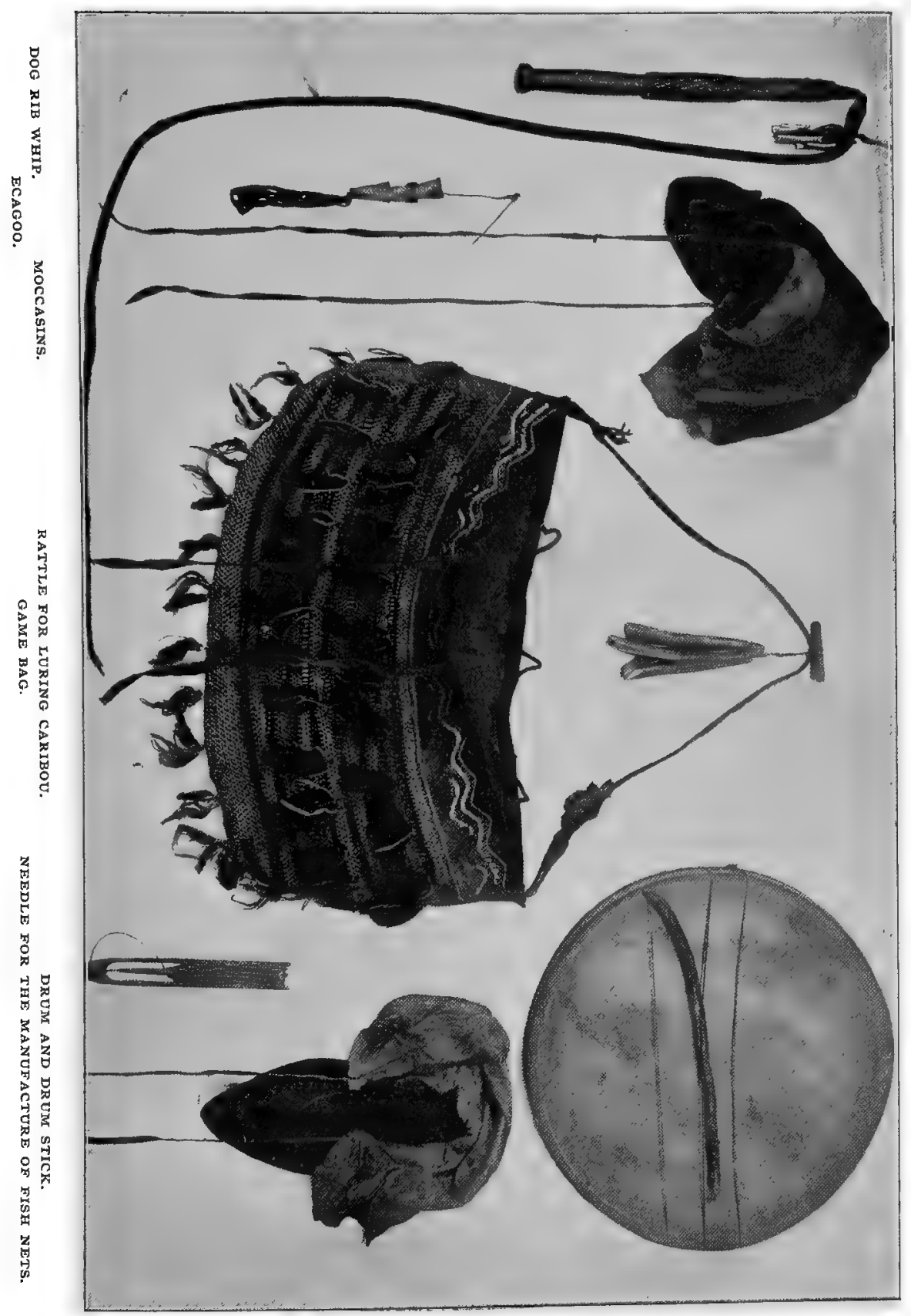






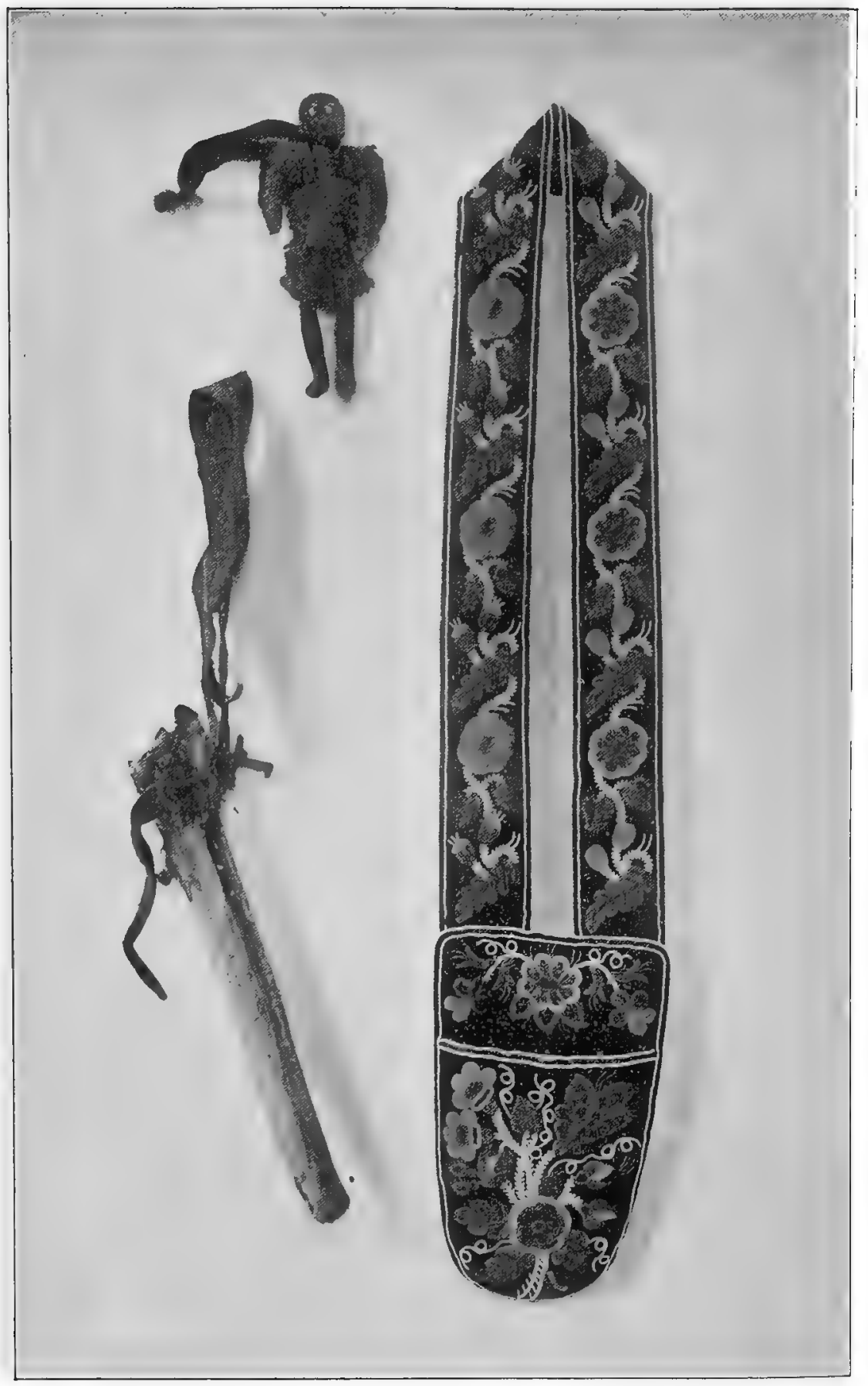

CREE MANITO PAUGUK.

CREE SHOT POUCH, NORWAY HOUSE.

GRAINING TOOL, DOG RIBS, RAE. 
of the Indian birch-bark canoe. It contains but a single piece of bark so that the seams between the sections of the large canoes are not represented. It is sewed at the ends and top with wattap which is 0.2 inch wide and so closely placed that there is no space between the turns except upon the curved ends. There is a light and roughly made gunwale nailed on outside the wattap binding. It is lined with spruce which completely covers the bark on the inside. There are ten ribs, rather roughly made. A thin upright piece at each end cuts off a short space next the stem and stern. It is gummed at the ends as high as the water line only. There are two paddles with the canoe, which are of spruce, 23 inches long and 1.8 wide. The blade is nearly as long as the handle; it is flat upon one side and convex upon the other; the end is sharpened at an angle of 45 degrees.

Skin Scrapers. There are four instruments in the collection which have been used in dressing skins; three are to be used with one hand and one is double-handled. No. II,548 represents the type that is most used. It is a graining tool made from the tibia of a moose, rounded off with an ax and obliquely cut to a sharp edge just above the distal enlargement. This edge is $I .5$ inches across and contains 13 teeth. Attached to the dried ligaments of the proximal end is a mooseskin thong which forms a loop which prevents the hand from slipping down the shaft. This specimen was obtained at the Grand Rapids of the Saskatchewan and is almost identical with No. 10,838 from Rae.

There is a scraper, No. II, 228 , of the same pattern from the Piegan Indian reservation near Macleod. It is of iron covered on the handle with cowhide.

The beaming tool, No. I I,547, from Grand Rapids, is a tibia with one side of the shaft cut away leaving a sharp edge. It is used as is a drawing knife, the broad ends serving as handles. When using this scraper the skin is stretched over a short, smooth log, six or eight inches in diameter.

Ladles. These are made of musk-ox or mountain sheep horn. Before the hunt in the spring of 1894 , there were but two in the camp of six lodges, but after we returned each family was provided with one or two, so that I supposed them to be lost or thrown away during their migrations when everything not abso- 
lutely necessary to their existence is abandoned. No. 10,842 was made by one of our party from a horn of the the first muskox killed. It was carved out with a crooked knife; being kept hot while it was worked by boiling or by holding over the fire. It is 8 inches long, the bowl being 4.5 long by 2.3 wide with sides 0.1 inch in thickness.

Gun Cases. All the Northern Indians have a covering of cloth or leather for their guns. These are usually of either moose or caribouskin, ornamented with fringes of quill worked leather strings, beads and bands of porcupine quills. The case is not fastened in any way and may be readily slipped off so that it is kept upon the gun until the hunter is about to shoot. Not unfrequently a wing shot is lost by the gun cover catching on the hammers in the excitement of the moment. I obtained a well-worn specimen, No. I0,839, from the Dog Ribs. It is of caribou leather, 52 inches long, 9 inches across the larger end, 2 at the other. It is made of two pieces with a single seam along the side sewed with heavy sinew. It is not ornamented save by a few tags of caribouskin at the smaller end. It is old, torn and a poor cover even for an Indian to carry.

There is another case, No I,090, which was made by a Trout Lake Indian woman, who had seen white people but on one or two flying visits to Providence. It is of mooseskin, well made and tastefully decorated. The butt is eight inches across and ornamented by two bands of porcupine quills, worked with a neat geometrical pattern in four colors and edged with beads. It is gathered over the hammer by another broad band of quills, and tapers slightly in the barrel to the muzzle which is surrounded by quills and terminated by a number of moose leather strings, Io inches long, whipped at the base with quills. A similar but shorter fringe of caribouskin is sewed under each band of quills. A half inch strip of strouding extends along the seam from the muzzle to the band six inches from the butt.

Game Bags. The various tribes of Athabascans use a game bag of their own manufacture, which is everywhere of the same pattern. It is woven from small babiche with an open mesh so that the snow will fall through and it is at the same time very light and strong. A line attached at the top passes across the points of the shoulders and the breast when carrying a load. No. I0,83I was obtained from the Dog Ribs. It is 20 inches 


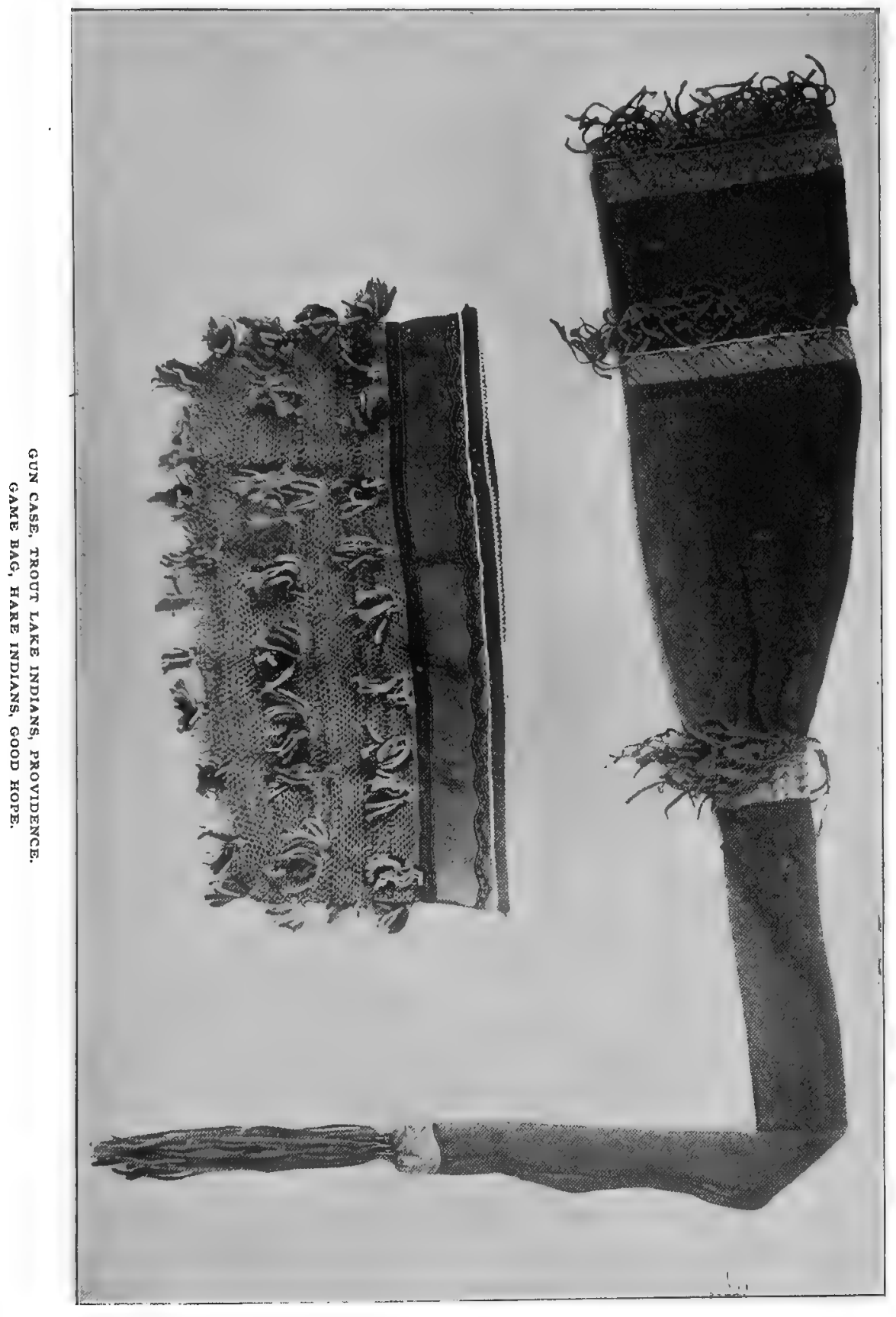



long and I deep. The front is made with eight bands of open work, each a half inch in width and stained black or red. The ends are of dressed leather, 2.5 inches wide. The back has five bands of open mesh one inch apart. The top is of caribou leather, 3 inches wide, with two sinuous lines of porcupine quills, which are sewed on without the slightest attempt at harmony of colors. There is a hem of blue strouding around the top. Three thongs in front serve to close the bag by passing through loops in the back. The front is ornamented by tags of colored worsted. The line attached to the end loops is of four-ply babiche, two feet long.

A specimen made by the Hare Indians at Good Hope, differs slightly in detail and is more decorated and with better taste.

Babiche. This is a line cut from a wet, partially dressed skin and stretched and dried. Two women work together in cutting babiche; one holds the skin and the line as it is cut; the other draws the knife in long steady strokes, skilfully gauging the width with her thumb. Two lines are usually cut together. A caribouskin fairly riddled with grub holes may be quickly transformed into a strong and serviceable line. The collection contains several specimens of babiche, No. 9,638, and articles made from it. No. 10,833 is a line used by the Dog Ribs in lacing sleds, etc. It is of six-ply braided babiche, 0.4 inch wide and 30 feet long. I saw a few an inch wide and several fathoms long and stained, but these were unusually large and they are not usually colored.

Deer Snare. These are now used as a last resort when ammunition cannot be obtained. I saw but two in the country. One of these, No. 10,839, is of three-ply twisted babiche.

Dog Whips. I purchased specimen No. Io,832 as a type of the dog whip used by the Northern Indians. The stock is of birch, a foot in length and $\mathrm{r}$ inch in diameter. There is a raised section in the middle, marked with raised incised lines. The handle is 4.7 inches long and enlarged at the end to prevent its slipping through the hand. The outer end is flattened on opposite sides to receive the broad thongs from the lash which are seized with babiche in two circular grooves. The lash is 50 inches long and 0.3 inch in diameter. It is smoothly rounded, ten-ply braid, and is loaded with shot. The cracker is II.5 inches long of three-ply twisted babiche. Near the handle 
there are eleven cylindrical tags of tin pinched upon the ends of short thongs. These make a loud rattling noise which the dogs recognize as a danger signal. I saw but one which was more elaborately carved and this was unfortunately lost when returning from the musk-ox hunt. The métis usually have a large bunch of worsted on the handle to prevent the whip from sinking from sight when dropped in soft snow. The whip is usually carried with a bight of the lash drawn under the belt.

Rattle. A child's rattle is sometimes made by the Dog Ribs. of shot and caribouskin parchment. I obtained a specimen, No. 10,827, which has a handle of birch bent in the form of an elongated figure 6 . It is 8 inches long. The head is 3 inches in diameter and 0.8 inch in thickness.

Idol. Old Ooskanatchet, of the Narrows of the Saskatchewan, made a small image for me, which he said represented the Cree death angel-the Pauguk, one of the most dreaded of the heathen deities. The figure, No. 9,6ro, is of moose leather stuffed with rags. The body and arms are sewed with a welt which projects half an inch and is cut in a fringe. There is an extra piece over each shoulder and a narrow apron in front, also fringed. The head is a flat piece of birch wood with a hole drilled through for a mouth and two leaden plugs for eyes; the face is concave and the back of the head convex. The face, shoulder and arm fringes and the middle of the legs are colored a deep crimson, probably with a dye obtained from the trader. The sides of the head are burned black with a hot iron.

Pipes. The Indians now use imported clay and wooden pipes and only two stone pipes were seen in the North, both of which were collected. One of these, No. 9,594, is of fine-grained sandstone, discolored and darkened through long use. It is ornamented with incised lines next the stem and with rows of irregular circular depressions around the top and base of the bowl. It is 2.3 inches deep and I.4 inches across the top of the bowl. The base is quadrangular, $I$ inch across and 3. inches long. The stem is 16.4 inches long and 0.6 of an inch in diameter.

The other, No. 9,632, is of fine grained schist with a brass finger ring around the top of the bowl. It is well made but without ornament except two incised lines upon one side of the base. The bowl is 0.8 inches across the top and 2.3 inches deep. The base is 1.7 inches long, 0.8 wide and 0.3 thick. 
Ecagoo. There are two of these in the collection, both obtained of Dog Ribs at Rae. I saw the same apparatus in use among the Stoney Indians of Morley, and among the Slaveys ${ }^{1}$ at Providence. No. I0,844 consists of three small pieces of bone rudely fashioned in hollow cones through which passes a slender thread of twisted sinew. Each cone is 1.5 inches long and 0.8 inch in diameter at the larger end. They are hollowed at the base so that they fit into each other. The thread is six inches in length and is attached to a strip of caribouskin at one end. This leather is 4.5 inches long and has nine slits reaching within half an inch of the ends and in which the point may catch in throwing. The needle is of bone 2 inches long and 0.1 inch in diameter. It is attached to the end of the thread which is towards the base of the cones. In using the ecagoo the thumb and forefinger grasp the end of the needle where it is enlarged by the sinew seizing, and the whole is swung outward and upward. The thread is just long enough to admit the point of the needle into the base of the first cone, when they are crowded into each other. The object to be attained is to pass the needle through the center of the cones or a slit in the leather at the top as the ecagoo falls. In gambling, a score is kept of the points made. Johnnie Cohoyla, from whom I obtained this, in the use of which he was an adept, said that the catching the point in the slits scored one, on the first cone, five, in first and second, ten, in all three, fifteen, and in second and third, twenty. I saw it used in his camp as a gambling device, but elsewhere merely as a child's toy.

No. I0,847, differs from this only in having a wooden needle.

Snow-shoe Needle. These are made of bone or wood and are used in lacing snow-shoes. A specimen in the collection from

1 The Montagnais of Labrador have a similar apparatus which Hind describes as made of wood and resembling the nah-ba-wah-gun-nuk of the Ojibways, which is constructed in the following manner: "The bones are made from the hoof of the deer or caribou, and made to fit one within the other to the number of $\mathrm{I} 2$, the one nearest the hand when the instrument is held for play being the largest. The players agree upon the stakes which are placed before them in the lodge, and one of them takes the bones and begins to play. His object is to catch as many as he can on the needle or skewer in a certain number of trials. The last bone, if caught singly in one of the holes drilled through it, counts highest; if the tail is caught it also counts next to the last bone." The Labrador Peninsula, Vol. I, p. 277. 
Grand Rapids, No. 9,612, is of bone. It is 5.6 inches long and 0.3 inch wide in the middle whence it tapers to a rather sharply pointed end. The babiche passes through a hole in the center.

Rabbit Snares. The northern hare is taken in snares made of wrapping or netting twine. To avoid the exposure of the hands, in setting them with slip knots to trip the spring, they are provided with short sticks which act as levers. A typical specimen, No. 9,6I7, is of wrapping twine 25 inches long with a slip noose at the lower end and a loop at the upper to pass over the end of the spring. The catch stick is 3 inches from the loop and is 2.7 inches long by 0.25 in diameter. It is fastened by a simple knot at each end.

Pack Saddles. The collection contains two frames from the Piegan reservation near Macleod. One of these, No. I I,230, is of two curved slabs of pine joined at the ends by strongly arched sections of deer antler. The sides are 18.5 inches long by 5.25 wide and curved to fit the back of the horse. They are firmly lashed to the arches which rise 4 inches above them and hold them 5 inches apart. The whole is covered with a single pice of rawhide. The girth was attached to thongs passed through two holes at each end of the side pieces.

Snow-shoes. There is a pair of small or "tripping" snowshoes in the collection, No. 10,826, from Grand Rapids. They were intended for use on hard snow, either upon Lake Winnipeg or in traveling behind a loaded sled through the bush. The frame is of birch wood, 42 inches long and 9 wide. The sides curve upward in front meeting in a point. Each piece is 0.8 inch wide and 1.25 inches deep. There are three bars; the smallest serves to spread the frame at the upward curve; 7 inches back of this is the toe bar, which is $I .2$ inches wide and 0.3 inch thick, with its edges well rounded. It is I 2 inches from this to the heel bar, which is somewhat smaller. The sides are fastened at the rear by a single heavy screw, the point of which is cut off flush with the surface. They are not "rights and lefts;" such shoes are not met with among the Wood Crees, Along the sides of the toe and heel spaces, a pair of holes a half inch apart appear at intervals of 2 inches, through which a strand of babiche is fastened in a simple knot holding a tuft of colored worsted on the outside of the frame 


and by the beckets on the inside affording attachment for the lacings. The foot lacing is of heavier babiche, with a little larger mesh, and passes at the sides around the frame which is wrapped with print to prevent wearing on the sharp edges. The toe hole is transversely oblong, 2.8 by 2.2 inches. The bridles on its sides are of 5 strands of babiche loosely wrapped.

There is also a pair, No. 10,849, of hunting snow-shoes from the same locality. They are 75 inches long and 15.5 wide. The side pieces are oblong with their greatest width transverse in front and vertical at the sides and rear. They curve upward I I inches in front where they meet in a point and are secured by two strands of babiche through holes on the inner side. They are not wrapped under the foot lacing. The holes along the sides pass obliquely outward and meet at the outer surface where they are closed by wooden pins. There are 5 bars, 2 of them supporting the frame in front of the toe bar. The toe hole is 4.2 inches wide, bordered by bridles of 4 strands carelessly wrapped. The upper surface of the bars and of the rounded point of the frame are dyed purple. These are typical specimens of the snow-shoes used by the Crees.

The pair of Loucheux snow-shoes, No. 10,848, in the collection is by far the most skilfully made of any that I have seen in the North. They are $6 \mathrm{I}$ inches long by $\mathrm{I} 2.5$ wide. The sides curve upward, but are broadly rounded in front and meet in a long lap-splice. The side pieces are elliptical, flattened in section, I.I inches in their greatest vertical diameter by 0.8 in the transverse. The side holes meet within the side strips and do not pass through, except at the foot lacing which passes through 5 holes. The beckets of the toe and heel lacing are short-I.5 inches, and the babiche used is very small. An incised line extends from end to end above the lacing. The foot lacing consists of 6 heavy transverse strands of babiche, the first 2 of which are gathered together behind the toe hole, and of 2 bridles of 5 strands neatly whipped, from toe to heel bar. Single strands of babiche, parallel with the frame, fill the rest of the space. There is a single strand of fine babiche passing along the middle of the toe and heel lacing; along this are oval spots colored, as is the entire framework; with red ochre.

Amulets. While with the Dog Ribs I noticed two bunches of antler points which were carried while hunting caribou, either 
through a superstitious belief in their aiding the wearer or to be used as rattles, as a piece of birch or deer's scapula sometimes is, to lure deer or moose within range of the hunter's rifle. Not without difficulty I secured a specimen, No. 10,846, which had been carried by Johnnie Cohoyla. It contains 4 points, 6 inches in length, which have been roughly cut from the antler with an ax. The tips are held within an inch of each other by sinew threads tied in a deep circular groove; these lines are braided together a distance of 2 inches and attached to the middle of a birch stick 2 inches long which is passed under the belt.

In addition to the specimens here described, the collection contains a number of articles which I obtained at Grand Rapids.

3 Stone pipes

I Clay pipe

2 Skin scrapers

I Flat skin scraper

Shot

I Pan

Fire steel

3 Buttons

Touchwood

Knife
Ǔs-si-mi-us-pwâ-gŭn

Wâ-pe-tu-nŭsk us-pwă-gŭn

Míq-kĭ-kwŭn

Pŭsk-wŭ-hi-kŭn

Sin-1̌-ĕ

Pi-we-biss wi-nă-gŭn

A-pět

Sa-go-pa-sŭn-ŭk

Pu-sa-gŭn

Mo-ko-män, Kich1-mo-ko-män

(Big Knife, name given to "Americans"-citizens of the United States. Compare the Athabascan Bischo.)

Canoe model

2 Paddles

7 Rogans

Birch cups

Flat sled
Wŭsk-wai-che-măn

E-pu-ì

Wŭsk-wai-ǐn-e-kŭm

Wŭsk-na minn-ı̌k-wă-gŭn

Nŭk-yŭ-ti-pän-äsk

6 Books printed in syllabic characters.

5 Letters written by Cree children.

Duffels, cradle, thread, moccasins, snow-shoe needle, netting needle, dressed skins.

\section{Methods of Dressing Skins Employed by THE Wood Crees.}

Moose. In former times, when the Indian was an unrestrained carnivore, moose might be had for the killing. Now they are becoming rare, though Grand Rapids is one of the 
posts at which they are sufficiently numerous to furnish all the leather needed in that locality.

With no other tools than a knife and the leg bones of the animal killed, and no other tanning agent than its brain, an "old wife" can convert a green mooseskin, weighing fifty pounds, into light serviceable leather in five days. The finished product is soft and pliable, nearly as thick though far inferior in wearing quality to cowhide.

The process, though simple, requires a good deal of labor. The fresh skin is trimmed and stretched in an oblong frame, 8 or to feet across, which is made by lashing four poles together. Every particle of flesh is then scraped or rather gouged from the inside. This is done with a graining tool made from a leg bone by cutting off one end and sharpening the shaft. This instrument applied for a few minutes to a green hide by a skilful "old wife," will save the future taxidermist hours of labor with the steel scraper.

When the skin is half dried the hair is scraped off. A horn or bone instrument may be used for this purpose, though the skins which I have seen dressed were trimmed with an adze made from an old hatchet blade, set transversely in a clumsy wooden handle which was about 18 inches in length.

The skin may now be dried as parchment and used in making carioles, etc.; if it is to be made into leather it is sprinkled with a little oil. Fish oil is preferred as it is most readily absorbed. It is then smoked slightly on the outside and soaked over night in water containing the brains of an animal from which the skin was taken, or from any other freshly killed. It is soaked the next day in water, then pulled before the fire until dry and soft. Finally the leather is smoked over a fire of rotten wood, until it takes on a light yellowish brown color; if ordinary dry wood is used it becomes black instead of brown.

Deer. A deerskin is treated in a similar manner until it is ready to be dried; it is thinned down by shaving on the grained side. The instrument used is the beaming tool. ${ }^{1}$ It resembles a carpenter's drawing knife but is pushed away from, instead of drawn towards, the operator. While it is being scraped the skin is held upon a peeled log which is 5 or 6 inches in diameter and as many feet in length. The leather is made much thin-

1 See p. 177 , ante. 
ner and softer than that made from mooseskin. The hair is usually removed from deerskin with a sharp knife after which the flat scraper is used. It is then soaked in brain water and hung out to freeze; when it softens a little it is taken in by the fire and pulled. An iron hoop, in which teeth have been cut, is hung on the wall by a line; the skin is then drawn back and forth through the hoop and is occasionally warmed before the fire during the process. If it is to be finished as white leather it is hung out of doors until bleached to a snowy whiteness. It is then smoothed with a piece of porous bone until it is soft. and velvety. 



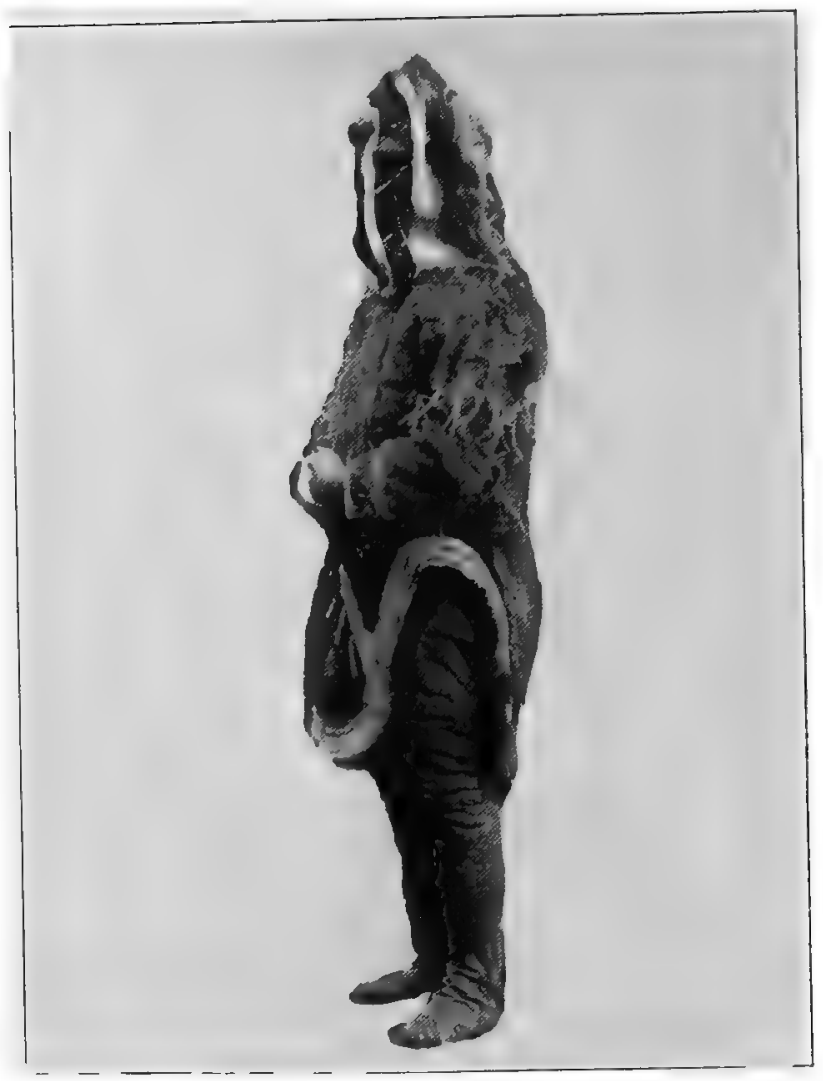

WOMAN'S DRESS, HERSCHEL ISLAND ESKIMOS. 


\section{CHAPTER XI \\ ETHNOLOGICAL MATERIAL OBTAINED FROM THE ESKIMOS}

$\mathrm{T}$

HESE specimens were secured from the central Eskimos who trade at McPherson, from Herschel Island natives. and from the Western Eskimos, either directly or through the kindness of the whalers. Such material has been sought after so long and so persistently that the only wonder is that a single genuine article of native manufacture and use remains. I was without goods with which to purchase specimens, and in many cases the prices demanded were exorbitant. The Eskimos made many articles for sale after ancient patterns which are now no longer used. Unless otherwise noted, the following brief descriptions are of specimens which show unmistakable evidence of their genuineness.

Clothing. The Eskimo costume is well suited to the needs of its wearer. The whalers have adopted it, even for summer use. Sealskin boots are supplied to every man before the mast, and seal and caribouskin frocks are always in demand. The women wear frocks with rounded skirts reaching to the knees and open at the sides.

Frock. The collection contains a specimen, No. 10,905, which was worn by a "Kosmollik" woman at Herschel Island. The body of the garment is of plain brown caribouskin in the summer hair. A large proportion of the costumes of the Herschel Island natives was of spotted Siberian reindeerskin, obtained both by trade among themselves and from the whalers. The hood is large but is not bagged at the nape for carrying a child. Its sides are cut from the under parts of the skin, so that the margin around the face and the V-shaped throatpiece on each side is white, shading into dark brown behind. It is edged with two strips of mountain sheepskin with the hair closely 
trimmed. The inner strip is .25 and the outer .5 inch wide, with bits of red and blue worsted, so small as to be scarcely noticeable, sewed in between. The back of the hood contains a narrow pointed piece, continuous with the body of the garment which is bordered by sheepskin. The front and back are each in a single piece. Under the armpits lighter colored pieces are inserted with tags of red worsted in the seams. The skirts are bordered by four strips of sheepskin with worsted in the seams, and trimmed with wolverine fur sewed to a half inch strip of caribouskin, having the fur inside. The arms are short; they are trimmed at the wrist by a half inch band of caribouskin. The seams, at the shoulders and elsewhere, are ornamented with a 3 inch fringe of caribouskin. The length in the back is 38 inches, the front flap being 2 inches shorter. It is 23 inches across the shoulders and 20 at the waist. The sleeves are 12 inches long and 7 wide. This is a rather plain dress frock, but is much better than those in common use which are lined with drilling or calico and worn with the fur side in.

Rain Frock. At Cape Tchaplin I obtained a specimen, No. ro,99I, of the "Massinker rain coat." It is a frock made of seal intestine, ornamented with narrow strips of the fur seal on the shoulders and hood, and with the hair of the young seal sewed upon the outside of the seams elsewhere. The hood is small and close fitting. The sleeves are 13 inches long and 8 wide. The strips of intestine are 4 inches wide and 6 feet long, the garment being 3 feet across the waist. There are 8 breadths in the front, making it 32 inches long. The wrists and skirt are trimmed with white hair, apparently plucked from a polar bearskin. The seal hair is not continuous but interrupted every 3.5 inches by a clear space of I inch. This garment was obtained from a wealthy young Tchukche, for whom it was more elaborately trimmed than such garments usually are. It is very light and flexible yet perfectly waterproof.

Trousers. Trousers are worn by the women both with and without a continuous foot covering. Those worn by the men are shorter and not attached to the boots. A pair of woman's pantaloons, No. Io,903, were obtained with the frock, No. I0,905, which are rather roughly made of winter caribouskin, worn with the hair inside. They are lower behind than in front and made to fit rather closely to the leg. The foot is unshapely 
and intended to be worn inside of boots. The leg is in a single piece ornamented along the outer seam with ten caribou leather strings whipped with red and purple porcupine quills. With the view to improve upon the appearance of this garment they often wear tight-fitting red flannel drawers outside.

Mittens. The collection contains a pair of mittens, No. I0,908, of polar bearskin, which were obtained at Herschel Island. They were said to be used temporarily as brooms in brushing away snow, with the long hair, rather than as a regular protection for the hands. They are short, unlined and without a connecting cord.

Boots. There are three pairs of boots in the collection, all of which were made upon the Siberian coast. A pair from Cape Tchaplin, No. I0,9I I, is of the common type used by the natives in summer, hundreds of pairs of which are made for the whalers. The soles are of heavy black sealskin roighly crimped The leg is of more flexible sealskin with the hair removed, and reaches above the calf where it is tied with a drawing-string of seal thong. There is a pair of broad thongs sewed into the seams on each side of the instep which pass through a loop on each side of the heel and around the ankle and tie in front.

Another pair, No. I0,9I2, from the same locality, has legs of sealskin in the hair which is worn outside. Hip boots are sometimes made of sealskin from which the hair has been removed.

I obtained a pair of dress boots, No. I0,9I0, which were made at East Cape, Siberia. The sole is of white whaleskin neatly crimped at the toe and heel. The leg is of Siberian reindeerskin in four pieces, those in front and rear being white with oblique patches of brown at the top; the side pieces entirely brown. Around the top of these is a band of marten fur I inch in width, above which is a $I$ inch band of caribouskin; the hair of this is trimmed in two bands down to the skin between which a strip of sealskin $\mathrm{I} / 8$ inch wide, holding tags of red and blue worsted, is sewed. At the top is a I inch band of dark caribouskin which contains the drawing-string of seal thong, which is about the size of common babiche. Between leg and sole is a piece of red-tanned sealskin, 3 inches wide. The grain side is out. The tie strings are of the same material. They are $I$ inch wide where they are sewed in above the red leather and are 30 inches long. 
Buttons. A few buttons of native manufacture are still in use. Specimen No. I0,908 will serve as a type. It is of walrus ivory, 1.75 inches in length. It is carved in the form of a whale with four transverse lines across the outer face. There is a slight projection on the back under which a hole has been drilled for the sinew thread.

Labrets. The majority of the men among the American Eskimos west of Cape Bathurst wear these alleged ornaments. While at McPherson my attention was attracted to one old man, with long snow-white hair, who had his face disfigured with an unusually large pair of marble labrets. The first man whom we met west of the Mackenzie wore a large, very conspicuous labret with half of a large blue bead attached to the marble flange and surrounded by a disk of walrus ivory I.5 inches in diameter. The practice seems to be falling into disfavor at Herschel Island, where several of the young men did not have their lips pierced; others wore but one labret, or a part of the time none. Several wore labrets made of glass stoppers, with the heads ground down for flanges. Individuals wearing one plug-shaped labret seemed to delight in shifting it with the tongue from one side of the mouth to the other.

Specimen No. I I,028 is of the commonest type. It is of polished marble with a rounded head 0.7 inch in diameter; the flange is $\mathbf{I}$ inch long and 0.6 inch wide; it is curved slightly to fit the jaw. This labret, purchased from the wearer, is almost identical in size and shape with a very old pair from a grave at Stokes' Point.

Another specimen, No. I I,O3I, resembles the ancient single labrets which are said to have been worn at Point Barrow. It is of steatite, 2.2 inches long by 0.9 wide and 0.5 inch thick. ${ }^{1}$

Pipes. The collection contains eleven pipes of walrus ivory and two with wooden stems. Those of ivory were probably made for sale, as they habitually use pipes with metal or stone bowls. A pipe from the Anderson River, No. I0,858, will serve as a typical specimen. The stem is of birch wood, I2.5 inches long, I.I in its greatest diameter and diamond-shaped in section. It is of two pieces, one upon the other, firmly lashed together with thong, which also secures the foot of the bowl. There is no mouthpiece or picker. The bowl is of iron, I.5

${ }_{1}^{1}$ See Murdoch, John, Ninth Ann. Rep. Bur. of Eth., p. I43. 


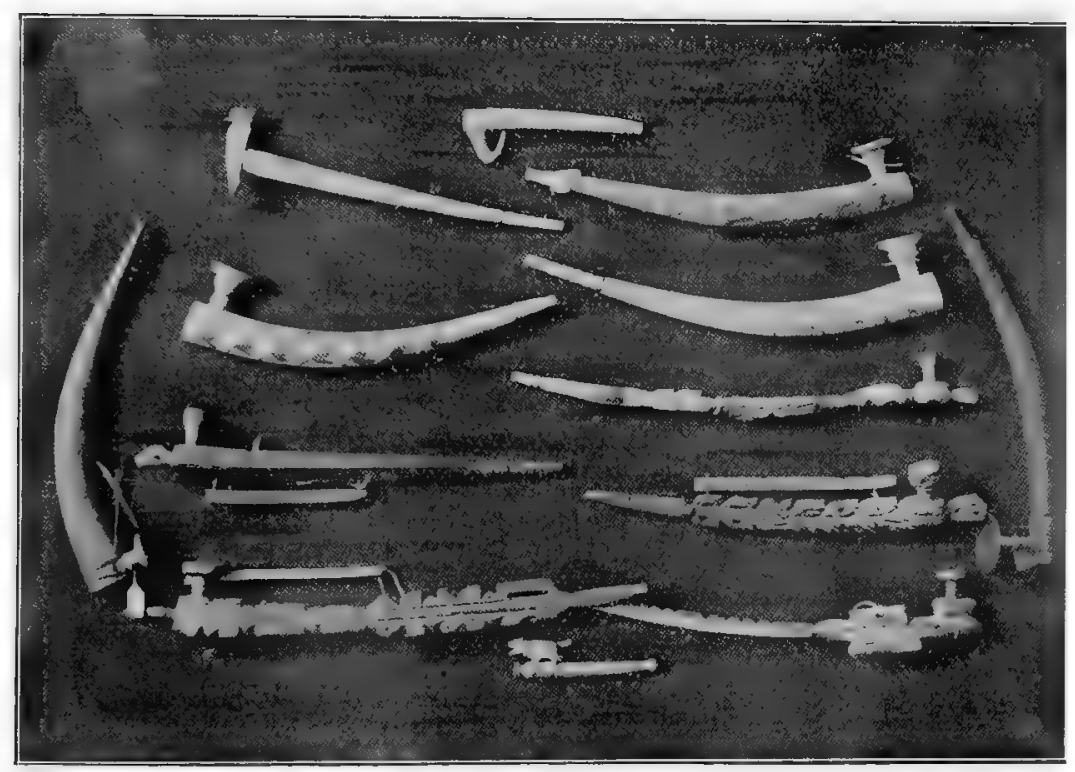

ESKIMO PIPES. 

inches deep with an internal diameter of only 0.3 inch. The slightly concave rim is of brass, 2 inches in diameter. This pipe has been used, as has No. II, 003 , which has a brass picker for cleaning the bowl attached by a double line of braided sinew. The mouthpiece is of ivory ornamented with grooved rings. The stem is of a single piece of birch, the hole through it having been drilled from both ends, meeting in an obtuse angle in the convex lower side where the opening is closed by a small piece of wood neatly inlaid. The larger end is closed by a brass cartridge. The bowl is of hard greenish-gray stone. This pipe was obtained at the Diomede Islands.

At present Herschel Island Eskimos use the clay or wooden pipes obtained from the whalers. They have learned to smoke cigarettes and the collection contains two carved cigarette holders of walrus ivory.

From a grave at Herschel Island a metal bowl, No. 10,952, was obtained, which has a shank of lead, lined with copper, and a copper ring around the middle. The saucer is surrounded by a thin band and its surface is inlaid with eight radiating strips of copper.

\section{Eskimo Weapons.}

The Central Eskimos are now supplied with American repeating rifles, notwithstanding the watchfulness of the United States revenue cutters which are directed to enforce the laws prohibiting the entrance of rifles and liquors to the Alaskan natives. Very few of those at Herschel Island would carry the light muskets used by the Indians. Shotguns are little used, and the strong sinew-corded bow will soon be known only by tradition.

Bows. The Eskimo bow, with its reinforcement of tightly twisted sinew cable, is far superior in strength and neatness to the self bows of the Northern Indians. Three specimens were collected, all of brittle spruce driftwood, straight when relaxed. The largest, No, 10,859, is 46 inches long, somewhat elliptical in section, flattened upon the back and narrowed and thickened at the handle and near the ends. The backing is a three-ply braid of sinew, twisted in two strands from a point 14 inches from the handle. Beyond the twisted portion it is whipped firmly around the bow in nine bands of 4 hitches each and one 
of Io. The backing is seized at the handle by sealskin. The string is of several strands of three-ply braided sinew twisted together. It is whipped with whalebone at the nocking point for a distance of 4 inches. This bow was obtained from the Richard Island natives, when they visited McPherson in July, I893.

The other two specimens were obtained at Herschel Island; they are provided with ivory bridges and do not differ from the "Arctic type" of Murdoch.

Arrows. There are eight arrows in the collection, which vary in length from 22.5 to 28.5 inches. Four are bird bolts with short shafts; the others deer arrows with long, barbed piles of walrus ivory. All but one have two feathers which are laid on straight; the shaft of the feather is split, the web is cut to less than half an inch in width and tapers to the ends which are seized with fine sinew the end of which is fastened in a slit on the stele; falcon and gull feathers are used. The shaftment is flattened, tapering and stained with red ochre; the shaft is from 0.3 to 0.4 inch in diameter and elliptical in cross section.

No. 10,865 is of spruce, 28.5 inches long. The pile is easily detached; it is 6 inches long, .6 inch in diameter with a sharp, four-sided point. There are three barbs on each edge. One side is more rounded than the other and both are ornamented with incised lines. The notch is U-shaped and deeply cut. No. 10,960 has a trihedral pile with three barbs. No. 10,863 is similar but much smaller, being only 22.75 inches long. No. Io,867 is a specimen of a common type of bird arrows, used to kill or disable without piercing. The head is cylindrical, .5 inch in diameter and 1.6 inches in length; four deep grooves or notches give the shape of a cross to the blunt end; the tang tapers to a point, so that the pile may be detached as easily as the barbed ones. No. I0,864 is much larger, with a short pile of heavy bone into which a cylindrical hole has been bored to admit the blunt tip of the stele.

There are twenty-five piles in the collection; they are made of shale, walrus ivory, bone and steel; there are four of bone which are deeply concave on one side, sharp edged, with four barbs near the base; they are from 6 to 8 inches long. There are four piles with a barbed ivory shank, into a cut in the end of which is inserted a sagitate head of steel. No. I0,953 is an iron pile, 3 inches long, with a blunt notched tip. It differs from 
the piles of the other bird arrows in the material from which it is made, and that the tang is wedge-shaped. No. 10,965 is of greyish shale, I.2 inches wide, and 2.2 inches long. No. 10,966 is of dark indurated shale, 2 inches long, .8 inch wide, with a a broad tang.

Harpoons. Eight harpoon heads were collected at Herschel Island; these are of walrus ivory and heavy bone. Owing to the presence of the whalers throughout the year, there is little need of such weapons, and they, with other articles of Eskimo manufacture, are going out of use.

Bird Darts. These are used in capturing large birds, such as geese and ducks, and are especially effective when the birds are unable to fly during the moulting season. They are provided with a long heavy head and a set of three prongs near the middle of the shaft, the object of which is to catch the neck of the bird if missed by the head of the dart. They are thrown by means of a throwing stick, of which no specimens were obtained.

No. II,032 furnishes a good example of the common type. The shaft is of spruce, 53.5 inches long and .5 of an inch in diameter; it is enlarged at the insertion of the prongs to a diameter of .8 of an inch; the butt is hollowed slightly to fit a projection on the throwing stick; the head is of walrus ivory, a foot in length; it is trihedral, with one sharp edge in which are cut seven barbs, extending to within 3 inches of the point; the tang is wedge-shaped, and secured by a whalebone pin and strong lashing of sealskin line; another line passes through a hole in its base and is made fast near the butt of the shaft. The prongs are of walrus ivory, attached 2 inches above the middle of the shaft; they are sunk in slits and bound at the base with braided sinew, an inch forward of this is a hole in each, through which the line from the head passes and secures the prong with two hitches around the shaft; two of the prongs have two barbs each on the inner edge, the third has a barb on each side, so that it would be of service only in piercing and not by holding the neck of a bird against the shaft.

No. I I,033 is somewhat smaller; its line is of two-ply twisted sinew; the prongs are directed forward until parallel with the shaft, and have four barbs each on their outer edges, making them effective as piercing weapons only. 
Knives. The Eskimos inhabiting the coast west of Cape Bathurst now obtain sheath or butcher knives from the whalers, or from the Hudson's Bay Company; so that flint and slate are no longer used for knife blades. Specimen No. I0,929 has a light ivory handle, 7.75 inches long; it is attached to the steel blade by steel rivets; the blade is 5 inches long and I. 3 inches wide. This and the crooked knives described below were taken from graves near Herschel Island.

The crooked knife with the Eskimo, as with the Indian, is an important tool, which he uses with considerable skill in carving and wood-working. One of those collected, No. I0,929, has a bone shaft I 3.5 inches long; there is a small piece of bone riveted to the back, apparently to allow the hand a better grasp. The blade is 3 inches long and 8 inches wide; it is curved upwards slightly in its terminal third. Another, No. I0,930, has a shorter, broader haft of a single piece; the blade has a uniform curve throughout, which is continuous with the curved end of the haft. The "woman's knife" is made by the natives from saw blades; the pattern, which is that of a mincing knife, and the manner of using remain the same as when made of stone; the women use them in cutting cloth, leather, or meat,-in fact for every purpose for which a knife may be employed; the cut is made by pushing. No. I I,OIO was obtained from Richards Island. It is of dark slate, 4.4 inches in greatest length and 2 inches at the back. It is 2.9 inches wide and .25 inch thick. The edge is beveled upon both sides, and worn blunt and smooth. It is without a handle.

Snow-knife. A large sabre-shaped snow-knife, No. 10,964, was obtained from Cape Bathurst. It is of coarse, heavy bone, flat upon one side, slightly and uniformly rounded upon the other, and equally dull upon the edges; a part of the point has been broken away; the handle is transversely notched, and the end enlarged to afford a better grasp; there is a hole at the end for the passage of a thong.

Bow Drill. The collection contains but one drill, No. I0,943, from Herschel Island. The steel point is I.4 inches long, .25 inch in diameter; the shaft is of birch, 10.7 inches long, tapering to a rounded end a quarter of an inch in diameter; the winged mouthpiece is of spruce, 3.6 inches long by 2 broad and I.I thick. The socket is made of a triangular piece of limestone. 
Fishhooks. A combined fishhook, sinker, and bait, No. I I,009, was obtained from the Anderson River Eskimos: It is of walrus ivory, 4 inches long by .7 .inch broad, and resembles a small fish in shape; the hook is a sharpened nail without a barb. It is weighted with five plugs on the side and a forked bar of lead upon the back; two small blue beads serve as eyes. They now obtain fishhooks from the whalers which they use in both coast and river fishing.

Net Sinkers. The net sinkers used at Herschel Island were of heavy bone, instead of stone, which is commonly used by all Northern Indians. The collection contains one set, No. 10,96I, which was made from cylindrical bone, 1.8 inches in diameter, sawed in sections, 6.5 inches long and again in half longitudinally; there is a groove sawed upon the convex side 25 of an inch from each end; they are attached to the net by twine passed through a small hole drilled in each end; another form,. No. 10,963, is cylindrical, 4.3 inches long, with a large hole through the outer rim at each end.

Net Floats. These are frequently made of cottonwood bark. Specimen No. 10,960 will serve as a type; it is in the form of a low pyramid with rounded corners; it is 4.3 inches long by 3.2 wide; a loop of whalebone is fixed at each end to two holes drilled half an inch apart.

Netting Needles. These are made of ivory or caribou antler. A specimen from Herschel Island, No. I0,95I, is of a poor quality of walrus ivory; it is 8 inches long, I inch wide at the base of the prong, and slightly narrower in the handle, which is 3.4 inches long.

Lamps. The soapstone lamp of native manufacture is being. replaced by imported oil stoves in which kerosene is burned instead of whale oil. A few are still in use at Herschel Island, where I measured a house lamp that was 18 inches long. The collection contains one traveling lamp, No. 10,928, of steatite from the same locality. It is 5.3 inches long by 3.2 wide, and is excavated to a depth of .5 of an inch; the wall of the more convex side is nearly vertical and ornamented with an incised line; the opposite side, which bears the wick of moss, slopes inward more gradually.

Hammer. The collection contains but one, No. I0,84I, which was obtained from the Anderson River Eskimos. The handle 
is of willow, 5.7 inches long; it passes around the head in a groove made to receive it and, doubling back upon itself, is firmly bound with babiche; the head is of a dark, coarse-grained trap rock and weighs $16 \mathrm{x} / 2$ ounces.

Harness Swivels. These are used to prevent the traces from becoming twisted. The collection contains two specimens from the Diomedes. They are of walrus ivory, with heavy. loops of seal thong at each end; the link of one, No. I I,004, is carved to represent a seal, with inlaid eyes of whalebone. It is 2.8 inches long and 1.2 inches in its greatest diameter. The pin is carved as a seal head and works freely in the larger end of the link, through which it is prevented from passing by a narrow shoulder. It is 1.5 inches long by .4 of an inch in diameter.

The other specimen, No. II,005, has a heavy barb of ivory instead of a link. A short loop is fastened to holes in the end of this and the pin turns upon the center. Both pieces are carved to represent seal heads.

Walrus Ivory. A few pounds of walrus tusks are yet obtained annually from the natives of Behring Sea and Strait. They are brought on board the vessels tied in pairs by a sinew cord passed through holes drilled in the point. An unusually large pair was obtained from the Diomede Islands. They are 33.5 inches long, and 3.75 inches in diameter at the point of insertion, whence they taper slightly towards the base and gradually to the blunt tips. They weigh 24 pounds.

Drawings. The Eskimos exhibit no mean degree of skill in drawing, carving, or engraving upon ivory. Captain Beechey, as early as 1826 , says of the natives of Kotzebue Sound: "On the outside of these instruments there were etched a variety of men, beasts, and birds, and so forth, with a truth and character which showed the art to be common among them." At both East Cape and Cape Tchaplin specimens of engraving were offered to us for barter. The designs were darkened with soot or gunpowder, and sometimes dyed red or green. The collection contains a slab of ivory, No. II,022, I7 inches. long, with I I figures of men, women, and seals engraved upon it. A companion piece, No. I I,023, has in the center a drawing of a building which has evidently been copied from a tea chest. There are two thin ivory plates, Nos. II,024 and 
I 1,025, which are 7.2 inches long by .8 inch wide, covered with small figures upon a convex surface and deeply hollowed upon the opposite side, where a number of incised lines suggest that they have been intended for hunting scores.

Fire Bags. These are not so important a part of the paraphernalia of the Eskimo as of the Indian or métis. The only one in the collection, No. 10,892, was obtained at Herschel Island. It is of caribouskin, dressed with the hair on, with a sealskin top and a sinew drawing-string. It contains three small pieces of flint, a small pouch of soft leather, containing willow catkins for tinder, and a slender link of steel made from an old file.

Ladles. Ladles of various sizes are made of bone, wood, and horn. The collection contains one, No. I0,908, from Herschel Island, of the horn of a mountain sheep. It is 2 feet in length and 6 inches across the bowl. A short crack in the rim has been closed with an iron rivet.

Needle Cases. One of these, No. I I,016, from the Diomedes, is of walrus ivory, 2.8 inches long and .7 of an inch in diameter. It is polished and stained with use. The cylinder is ornamented with 6 encircling lines. The strap is 8 inches long and has a metal trousers button at one end to keep it from slipping through. The other end forms a loop for attachment at the girth.

Omiaks. The Eskimos are obtaining whaleboats from the vessels at all the settlements on the Arctic coast as far eastward as Cape Bathurst, so that the large skin boats, or omiaks, are now seldom used in whaling. Nearly every family at Herschel Island which did not have a whaleboat owned an omiak. The frame is made of spruce driftwood, of which there is an abundance along that coast. The boats, or canoes, as the whalemen call them, are light and easily beached. The covering is of walrus, seal, or even bearskin, sewed in a double seam with a blind stitch. I saw only a few of them in use, but all required occasional bailing. I noticed both men and women in them on several occasions; the women pulling independently of each other at the short and narrow oars, and the men paddling and pushing aside ice floes.

The collection contains an omiak model, No. 10,999, from Point Barrow. It is 33.5 inches long, with a depth of 4 inches, and a 9 inch beam; being proportionately too broad, as an 
omiak 30 feet long does not exceed 6 feet in the beam. It is covered with a single piece of light yellowish sealskin stretched on without any seam. It is sewed to the gunwale, the ends of which pass through holes in its edge near the bow and stern, and are lashed with seal thong over the gunwale to the inside streak along the sides. The keel is broader than deep, and fastened with a scarf joint and tree nails to the stem and sternposts. The stem is bent upward in the knee, having a greater rake than the stern. Both are broad and flat on the inside and taper to a sharp edge, continuous with the keel. A short board is lashed to the top of each, that in the stern affording a seat for the steersman. The bilge-streak is deep and narrow and lashed in an offset in the stern. The side streaks are inside the ribs, and are 6 in number, and are lashed to the bilge streak and gunwales, against which they rest with notched ends. The gunwales are round, and project at the bow until they meet, but without fastening. At the stern they project an equal distance, and are separated by a space of I inch. There are 5 narrow floor timbers, and 3 thwarts.

Scrapers. I obtained two skin scrapers, which had been made at the Diomedes. No. II,027 is a fair specimen of the type most commonly used. The handle is of fossil ivory, 4 inches long, 2.2 inches wide, and strongly arched. The upper surface has two long and shallow grooves for the fore and middle fingers. The left side is deeply hollowed to receive the thumb. The right side is deeply excavated for. the third and fourth fingers, which are separated by a projecting ridge. The butt is slightly flattened. It must have been recently made, for it is nearly white, though smoothly polished. I have seen several that were stained a dark brown with age and oil. This handle contains several cracks which are bound with whalebone, and prevented from extending farther by holes drilled at their ends. The blade is of flint, .5 of an inch long, 1 inch wide, tightly wedged into a groove 1.6 inches wide.

The other specimen, No. I I,026, is a wooden handle without a blade. It is smaller and more roughly made than No. II,027. There are two circular depressions for the fore and middle fingers; the third and fourth are not separated. A deep vertical furrow crosses the hollow from the left side, perhaps intended to prevent the thumb from slipping. 
Another model that I noticed had a curved projection between the thumb and forefinger which prevented the hand from slipping forward.

Mode of Burial. Soon after my arrival at Herschel Island, the death of an old woman gave me an opportunity to see how an Eskimo funeral was conducted. The preliminary ceremonies were concluded before I heard of it, but I was an interested spectator at the tomb. The corpse was wrapped in two woolen blankets, a robe of heavy winter caribouskin, and a robe of light summer skin; the clothing of the deceased, consisting of calico and Siberian reindeerskin frocks, was laid over the body, and the whole was enclosed with several yards of gray flannel, securely lashed with seal thong. Two heavy logs, 6 to 8 feet long, were placed transversely at the head and foot of the corpse, which was laid upon the surface of the ground. Smaller logs were laid across these, parallel with and entirely covering the body. Short, heavy pieces were inclined against the sides and placed across the top, making the whole about 3 feet high. A medium sized kumotik, in good condition, was left beside the tomb. Knives, needles, and other personal property were placed with the body, showing that six years of contact with the whites had not affected their burial customs.

\section{Cranta.}

While at Grand Rapids, I obtained three crania and the greater part of three skeletons belonging to the race which occupied the Winnipeg region prior to the advent of the Crees; also two skeletons of Wood Crees. At McLeod I collected the cranium of a Piegan. I secured two Dog Rib skeletons at Rae; and at various points between the mouth of the Mackenzie River and Herschel Island, I collected nine crania of Western Eskimos.

A few of the most important cranial measurements are presented here; the small number prevents a detailed account being given. The cranial capacity was obtained with a set of Broca's gauging instruments and No. 8 shot. 


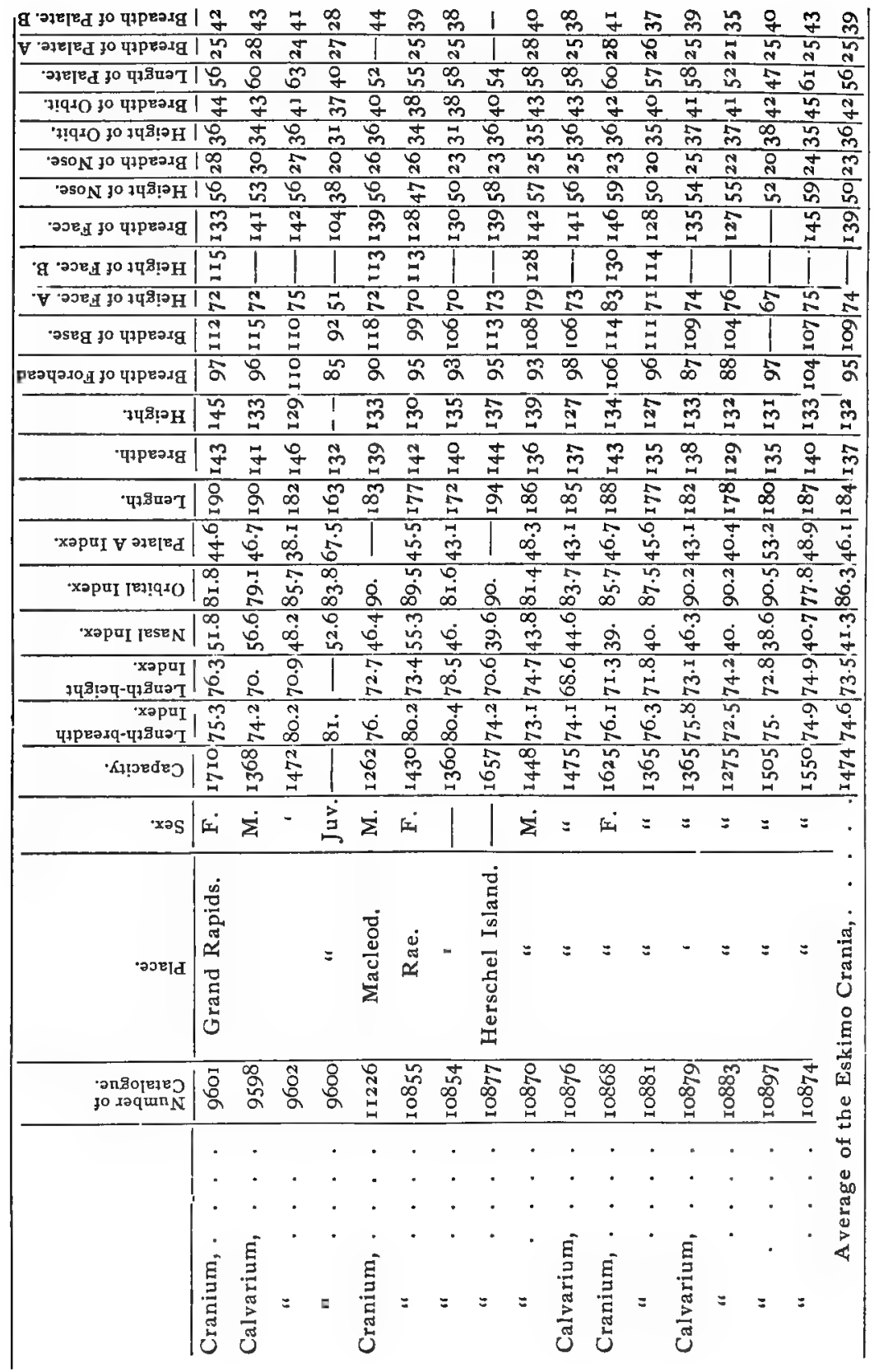




\section{CHAPTER XII \\ MYTHS OF THE WOOD CREES}

$\mathrm{T}$

HE Grand Rapids natives seemed quite willing to aid me in recording their myths, yet the number of these tales was much less than I had expected. "Old Joe" 1 was always pleased when he found "a new story" among his "band" for me, after the more common myths had been written, and, as he was one of the most influential men in the tribe, I think that most of the myths known to them were told to me. Not all of the mass of exceedingly vulgar material which was offered has been rewritten for publication. To the credit of the narrators be it said that they apologized for the coarseness of many of the tales, saying, "It is not fit to tell a bourgeois (the term applied to officers of the company and travelers passing through the country, all other whites being known as 'servants' or voyageurs) but then I did not make the story you know."

The myths are written as nearly as possible in the words of the interpreters. I did not acquire a sufficient acquaintance with the language to consider it advisable to attempt to write the Cree text.

Wisagatchak is the central figure in their mythology; the tales relating his marvelous adventures "would take a summer and a winter in the telling."

Petitot gives a brief account of the Wisagatchak creation myth, ${ }^{2}$ and then states ${ }^{3}$ that the history of Wisagatchak continues and blends with that of Efwa-éhé of the Hares. He caused the animals to suffer, the buffaloes to die through loss of breath, he flattened the face of the lynx, produced touchwood by burning his own fiesh, and, finally, he assembled all

1 See p. 2, ante.

2 Traditions Indiénnes du Canada Nord-Ouest, p. 472.

B Ibid, p. 474 . 
the animals in a great medicine lodge which he shook and pulled down, and in its downfall all animals perished. "Wissaketchok is then, at once the Noah and the Sampson of the Crees."

The story of the deluge which here appears is quite different in its details from that given by Petitot, and of the other tales which he mentions, only one, that accounting for the origin of touchwood, was related to me.

\section{The Beginning of Wisagatchak's Wanderings.}

Wisagatchak's father was very found of roast beaver. Every day he hunted his favorite game and every evening, when he returned, his wife had no wood for the fire. As it is one of the first duties of a good wife to procure firewood, he became suspicious of her conduct and asked his two little sons, "Where does your mother go every day?" "She takes her robe and goes off that way," said they, indicating her course.

The next day he killed a beaver, as usual, but left it where it lay. In the morning he told the old wife to go after the game, and as soon as she left the camp he hastened away in the direction in which she was accustomed to go in his absence. He followed her track until he came to a hollow stump which was full of snakes. The reptiles hearing his footsteps, and thinking that they were made by the old wife, came rushing out to meet him with a more than cordial greeting. Angered by the perfidy of his spouse, he killed the snakes and took a quantity of their blood back to the camp with which he made a rich soup. The woman, upon returning with the beaver, suddenly became very industrious and volunteered to go after firewood.

"Eat, before you go," said he, placing the soup before her She ate it greedily and pronounced it very good.

"That is the blood of your snake lovers."

"If you have killed them, I will kill you," she cried, running off in a rage. Calling his boys to him, the father gave them a flint, an awl, and a beaver's tooth, saying, "Be off, I am going to kill your mother."

When she returned, they began a desperate fight. After a long contest he succeeded in cutting off her head which went rolling swiftly away. The headless body continued the struggle 
and the pair began to ascend into the heavens, where, still fighting, they became lost to view forever.

The head fell upon the trail of Wisagatchak and his brother and started in pursuit of them. The boys saw it coming and knew that it meant to kill them. Throwing down their awl, they wished that it might become a mountain covered with awls, their bristling points upraised to stop the pursuit of that terrible head. Their wish was, of course, granted, but the head, only retarded in its progress for a short time, came bounding after them again. Throwing down their flint, they wished that it might become a mountain strewn with sharp and rugged rocks. Even this proved unavailing. Only the beaver's tooth remained, and this was cast down with the wish that it might become a broad river. On coming to the stream, the head rolled into it only to bound back upon the bank unable to cross. The head called to a pelican to come and carry it across. This the bird tried to do, but on being addressed with offensive language threw off its burden in midstream. The head was instantly transformed into a sturgeon in the magic river. Breaching high above the surface the fish cried, "As long as the earth shall stand I shall be called nemao!"

\section{How his Brother was Transformed into a Wolf.}

Wisagatchak was older than his brother, and naturally took the lead in their subsequent adventures. As they were playing by the river, the younger boy began crying. To divert his. attention, Wisagatchak gave him a string of bears' claws. Just then an old man, named Waimesosoo, came down the stream in a canoe. He made no stroke in the water with his paddle, but simply struck the top of the canoe which shot swiftly through the water. Seeing the children he stopped close beside them, and on catching sight of the bears' claws, he transferred them to the canoe by a mere effort of his will. Wisagatchak protested against this robbery, saying, "You will make my little brother cry again." "Come and get them then," said old Waimesosoo, putting out his paddle for the boy to step upon. As soon as his foot touched it, Wisagatchak was thrown into the canoe which sped rapidly away. Seeing himelf thus deserted, the little fellow on the bank dolefully cried, "Nĕs-te-se nă-cu-ta hoo-yi-na ěs-i-gŭm ně-me-nŭ-cu-nĭ-wĭn" -If you leave me I will 
turn into a wolf. Such indeed, was the fate of Wisagatchak's brother; slowly, one side at a time, he became transformed into a wolf.

\section{How he Found a Wife.}

Waimesosoo carried Wisagatchak far away, but the canoe touched the shore at last and was hauled up and overturned with the boy under it. The old man went up to his lodge, and told the elder of his two daughters that he had brought home a husband for her. The girl went to see Wisagatchak, but said, "Oh, that is only a boy, and he is too ugly, anyway."

The younger sister was better pleased with him and brought him new clothing, which transformed him into a strong and handsome young man.

"We will both have him," said the elder daughter.

"Oh, no! you had the first chance and you did not take him."

It seemed that old Waimesosoo had a habit of kidnapping young men, only to exercise his ingenuity in killing them. Wisagatchak was put upon his guard by his new-found wife. One day the two men went to gather eggs among the islands. Waimesosoo kept urging his son-in-law to go farther out.

"The eggs are better beyond. You will find some nice yellow ones on the little island, away there," said he. As soon as they reached the island the old man upset Wisagatchak's canoe and deserted him. Wisagatchak killed a gull and exchanged its body for his own. He reached home before Waimesosoo, who found his little grandson eating a gull's egg nutside the lodge.

"Where did you get that?"

"My father brought it."

"Oh, no. I offered him as a sacrifice," said the old man, but a moment later he was greeted by the smiling manito in his proper person.

Not long afterward they made a journey to a distant island to procure some arrow wood for the son of Wisagatchak. Again Waimesosoo deserted his son-in-law, who escaped as he had done before. Upon his return Waimesosoo found his grandson shooting with his new arrows.

"Where did you get those arrows?"

"My father brought them."

And the old man knew that he was again foiled. 
A third time they set out together, intending to procure some quills for the arrows obtained upon the preceding trip. They came at last to an island upon which lived an enormous eagle.

"I will give this man to you to eat" said Waimesosoo, deserting him as before.

"Oh, I know you from long ago, we are old friends," said Wisagatchak, and he flattered the eagle until he was allowed to escape in the form of a gull. On reaching home Waimesosoo boasted to his grandson.

"You will not see your father any more, for I have given him to the great eagle."

"See the quills he has just brought me," replied the boy.

On the following day Waimesosoo said, "Let us go and have a swing." The swing was upon the verge of a precipice and had frequently been used by the old man to destroy his victims. Wisagatchak knew that he would be hurled out of the swing by a jerk of the rope, and just as the act of treachery was performed he transformed himself into a crane, so that instead of falling headlong upon the rocks below he flew gently down in safety.

"Now, it is your turn." said Wisagatchak, and he swung the old man long and high, finally tripping him at the right moment. Waimesosoo assumed the form of a whiskey jack to escape being dashed to pieces. Wisagatchak blew so hard upon the little bird that it was killed by the violence of the gale and the long contest was ended.

Wisagatchak returned to his home alone, but not to stay, as he was destined thenceforth to be a wanderer upon the face of the earth. He met with many strange adventures, and could talk with all the animals, and trees, and stones; all spoke the language of the Wood Crees. It seems probable that the point of this myth has been forgotten, and the one which accounted for the origin of the sturgeon has been lost by interpretation into English; the mischievous whiskey jack (Perisoreus Canadensis) ought to have originated in this way instead of being destroyed.

\section{The Creation of the World.}

Nearly every people has its own legend to account for the creation of the world, and among the Wood Crees this is not wanting. It is a combination of a creation myth and the equally universal tradition of a flood. 
One day Wisagatchak's brother "was going along," in the form of a wolf, and was feeling very hungry. Coming upon the trail of a moose, he followed it until he came to the shores of a great lake. He had been warned by Wisagatchak not to venture into the water, for in it lived the long-tailed misipisiwuk (lynxes) which would kill him; but hunger overcame his prudence and he followed the moose track into the lake, with fatal result.

When the wolf did not return, Wisagatchak traced him to the lakeside, where he found a kingfisher, which was sitting upon a dead branch, looking out upon the lake and,mournfully crying.

"What is the matter?" asked the manito.

"My spear is too small," was the reply. Wisagatchak made the bill of the bird long and sharp, as it remains to this day, saying, "now try it." The first dive resulted in a fish being impaled upon the perfected spear.

"What were you looking at when I came along?" asked Wisagatchak.

"I was looking at a wolf's tail which the misipisiwuk were playing with."

"What do they do in the middle of the day?"

"They come ashore on that sandy beach to sleep."

The manito then provided himself with a spear and went to the sands, where he transformed himself into a pine stump to await the coming of the lynxes. Some of the wisest of these were alarmed when they arrived, declaring that the stump had not been there before, but the others were as positive that it had. Two of the strongest misipisiwuk tried to dislodge it by locking their tails together and pulling, but as Wisagatchak retained his hold they decided that it was certainly a stump and proceeded to frolic about on the shore. When all were tired and had lain down to sleep, Wisagatchak resumed the form of a man, caught up his spear and killed them one by one, leaving his spear sticking in the last, which still lived.

This resulted in the waters rising until the earth was flooded. Wisagatchak built a raft and placed a bit of earth in a tree. The water rose so rapidly that he forgot this in his haste, when he embarked upon the raft. While floating, he heard something gnawing at the logs beneath. 
"Who is eating the logs of my raft?" he cried, and a big beaver thrusting his head above the surface, answered in person.

"What were you doing there?"

But the beaver only laughed in reply, exposing his teeth. Wisagatchak, angered, knocked some of his teeth out with a sudden blow, hence the gap which exists between the incisors and molars of the beaver.

Suddenly the raft began to sink and the manito saw that the misipisiwuk were dragging it down.

"You can't sink the raft that way, just put your tails on the side and overturn it," which the unsuspecting lynxes tried to do; but no sooner did their tails appear on the side than the manito cut them off, and the wildcat tribe is tailless to this day.

Wisagatchak was not alone upon the raft, but was accompanied by his brother, the wolf, who had been restored in some miraculous manner, and by all kinds of animals. He was now anxious to recreate the earth; he therefore ordered the muskrat to dive down and bring him a little mud from the submerged land. The rat obeyed his master, but was unable to reach the bottom, and drowned before he could rise to the surface again. Wisagatchak thereupon restored him to life, and promising to resuscitate him yet again, should he die, ordered him to try once more. This time the rat was more successful, for he caught a little mud in his mouth and one paw, but came back lifeless. Restoring the rat to life a second time, this master of all the living creatures laid the mud in the sun to dry, and then blew upon it until it begun to grow larger and larger. At last he sent his brother out to see if the world was big enough. The wolf did not return for a long time but Wisagatchak was not satisfied and again blew upon the earth increasing its size. The wolf was again sent out but never returned, whereupon the manito decided that the world was large enough and the occupants of the raft were landed.

\section{Wisagatchak as a Doctor.}

One day, as Wisagatchak was going along, he discovered a strange track. After following it a short distance he heard the sound of a conjurer's rattle and soon saw an enormous frog who informed him that he was a doctor.

"Where are you going?" asked the manito. 
"To visit the wounded misipisiwuk that Wisagatchak speared."

"How do you treat them?"

"I blow this way," said he, inflating himself vigorously, "then I use my rattle."

Wisagatchak killed the frog and put on its skin. He then set out for the lodge of the misipisiwuk who admitted him without question, as the frog had been treating their wounded comrade for some time.

"I am going to employ a new remedy," said he. "Put out the fire and darken the lodge." This order was obeyed and then taking hold of the spear, which had been nearly removed, he thrust it deeper than ever, remarking that it was very warm inside. The false doctor left the lodge. The misipisiwlk becoming suspicious at his long absence went out and found the frog skin and the rattle lying beside the door, and on lighting a bit of birch bark they discovered that the patient was dead. Whereupon an old wiseacre remarked, "It is always dangerous to have anything to do with Wisagatchak." ("When you sup with the devil," etc.)

\section{Why Some Trees are Twisted.}

One day, as Wisagatchak was going along, he came across a bear lying in his path.

"Get up you lazy beast, you sleep too much," he said, giving the bear a kick, but finding that it was dead he thought to himself, "Now I will have a feast." So he built a huge fire and roasted the entire animal. "I cannot eat all that," thought he, "without making room in my stomach." So he placed himself between two trees and told them to squeeze him. The trees complied but warned him that they would not let him go, but they relaxed their hold and he began to eat, soon returning, however, to give the order, "That is not enough, you must squeeze harder." This time the trees were true to their word and held him fast. The whiskey jacks came to feed upon the roasted meat, then came the crows and all kinds of carnivorous birds and mammals, until nothing but the bones remained of the delicious repast. Then the trees released him. In his anger, Wisagatchak caught their tops and twisted them so far 
that they remained permanently awry, which accounts for the occurrence to this day of twisted trees which will not split straight.

\section{How Animals Obtained their Fat.}

"I will have my share after all!" said he, as he gathered the bones together that he might boil them and extract the grease. Putting this in a bladder, he went down to a little river to cool it. There he heard somebody crying, which he soon found to be a muskrat. "What are you crying for, my little brother?" asked the manito.

"My tail is too big," was the reply, and it was indeed true; the little animal was unable to manage the broad, beaver-like caudal appendage which clogged his movements. Wisagatchak stripped away its sides, making it small and narrow.

"Is that the way you want it?"

"Yes," said the delighted rat, beginning to play about the water.

"Take this grease and swim about with it to cool it, but go slowly," said he, as he tied the bladder to the rat's tail. The muskrat soon began to swim faster and faster until checked by the hungry manito, who again cautioned him. The rat went slower but gradually swam beyond reach.

"Now," said the rat, "I will play a trick on Wisagatchak."

So he dived beneath the bladder, and gnawing a hole in it allowed all the tat to escape.

Wisagatchak, unable to save it, called all the animals of the forest about him. Taking the rabbit he threw it into the stream but withdrew it as soon as a little fat had adhered to its neck and breast, where it remains to this day. All the animals were dipped in the river; the bear, being allowed to remain longest, secured the most fat.

\section{Wisagatchak AND THE GRIZZLy.}

One day, as Wisagatchak was going along, he came upon an unusually large pine tree. He noticed the excellence of the wood and decided to use it in the manufacture of a full set of weapons. He fell to work cutting and splitting the trunk into billets from which he made knives, hatchets, and arrows. "Now," said he, "I wish that I could meet a grizzly." 
His wish was soon gratified, for he came upon one which was digging roots near by. Wisagatchak fired an arrow, but it broke against the bear's tough hide. Another and another shaft was sent until his quiver was empty, and he took to flight with the grizzly in swift pursuit. As he ran, Wisagatchak turned and hurled one of his hatchets which shivered to pieces against the head of Bruin, as were the others in quick succession. The bear was now so close that the fleeing manito turned and struck at him with a knife, but it, too, failed him. After breaking all his knives, he came to a little bush around which the chase continued. There was a moose horn beside the bush, partly buried in the earth. Every time he passed this he gave it a kick, until it became loosened so that he snatched it up and made such terrific passes and bellowed so loudly that the grizzly fled in terror. What effect this had on anything "to this day" is not divulged.

\section{Wisagatchak and the Night HaWk.}

One day, as Wisagatchak was going along, he came across an enormous granite boulder.

"Now, let us have a race," said he to the rock.

"No," was the reply, "I am fixed here forever."

"Oh, come on," and off they went, down a long incline, the manito in front with the boulder following close behind After a long chase the rock overtook him and leaped upon his back pinning him to the earth. After vainly trying to escape, Wisagatchak called to everything which passed for help. His entreaties were in vain, until a night hawk flew over them.

"My little brother, come and take away this rock," he cried. Down swooped the night hawk, utternng its peculiar and characteristic booming sound as it struck the boulder a terrific blow which split it in twain and released the prisoner.

\section{The Thunderbolt.}

One day, as Wisagatchak was going along, he came upon a large granite boulder.

"Let us have a race," said he.

"No, I am to remain here as long as the world stands," was the reply, but he prevailed upon the rock to run at last, and away they sped. They ran until the boulder overtook the manito, 
as they were descending a hill, and leaped upon him and pinned him to the earth.

"Come, my brother, let me go," he entreated.

"No, so long as the earth remains and waters run you must stay here," said the rock. Wisagatchak then fell asleep; he awakened after the lapse of years to find that his face was overgrown with lichens and his hair was full of moss. Then he called to the thunder, "My brother, take this rock from my back."

The crushing weight was immediately broken and scattered over all the land, where the fragments are seen to this day.

\section{OKASKEWAYSESUK.}

As Wisagatchak was going along, one day, he came upon a pack of young grouse.

"What is your name," said he.

"Okaskewaysesuk" (I-startle-you), they said.

"You cannot startle me," said the manito as he continued upon his way. The old grouse returned to find her brood sadly frightened. Meditating revenge upon Wisagatchak, she collected a great covey of her friends and relatives together upon the banks of a small river, where they concealed themselves in the path of the advancing manito. When he reached the bank of the stream Wisagatchak concluded that he could jump across it. Moving back some distance to gather impetus he rushed down the bank only to pause at the brink without leaping. A second time he ran, and a second time his courage failed him. "I will jump this time," said he, and the listening grouse knew that he meant to make the attempt. Just as he was springing into the air the grouse started up in a body, producing such a sudden noise and confusion that Wisagatchak, instead of clearing the stream fell with a splash in the middle of the current.

"Yes, it is true they ought to be called Okaskewaysesuk," he soliloquized as he pulled himself up on the bank.

How the Ermine's Fur came to change with the Season.

Wisagatchak was once more free. As he was going along, he fell upon the track of a bear. The bear turned upon him saying, "You will be a dead man before the day is done. Gather firewood at once, I am going to roast you." 
Wisagatchak was thoroughly frightened, and at once obeyed. In his search for wood he found an ermine, to which he appealed for assistance.

"My little brother, you can save me from the bear; you run and jump down his throat and gnaw his heart. Do not be afraid for I will not let him kill you."

The ermine did as directed. The bear became impatient.

"Be quick! be quick! my heart is aching!" and again, "hurry! hurry!"

Wisagatchak purposely delayed until the bear fell, dying from the wounds inflicted by the little ermine. Then he threw heavy sticks upon him, saying, "There is your wood, much good may it do you."

In those days the ermine's fur was red, making it a pretty but conspicuous animal. Wisagatchak found that his little friend had perished, but life was at once restored by the manito, who dismissed him with these words, "You have helped me, my little brother, I will reward you by changing your color, so that your enemies cannot see you. You shall be brown in summer and white as the snow in winter."

\section{How Touchwood Originated.}

One day, as Wisagatchak was going along, he came upon a large flock of waterfowl, including a number of nice fat geese. Quickly forming a plan to get some of them, he went into the muskeg and gathered a bag of moss with which he approached the geese, who called to him, "What have you in that bag?"

"Those are my songs, I am a musician."

"Make us a dance, then."

"All right," said Wisagatchak, "I will make a big medicine lodge, and you must do as I tell you in the song."

They promised to do so, and fell to dancing, gradually arranging themselves in a long line with their necks crossed and their eyes shut as the song proceeded. A loon near the door noticed that the manito sometimes mumbled his song or ceased altogether for a moment; becoming suspicious, he opened one eye a little and saw the singer biting off the head of a goose, several of which were already lying dead.

"Ho, Wisagatchak! Wisagatchak! He will kill us all!" cried the loon. Everything was instantly. in an uproar. As the 
fleeing birds passed him, the angry manito gave a savage kick at the loon, driving its legs far back, where they are fixed to the present day. Wisagatchak made preparations to have a feast. The geese were buried in the sand with their legs above the surface, and a roaring fire was built over them.

"Now," said he, "I will have a nap while they are roasting."

One side of his body was to remain on guard while the other slept. The sleeping side was soon awakened to be told that a boat load of foxes was passing. They soon disappeared and the waking half was so berated for disturbing the slumbers of the other, that it resolved to go to sleep also, and not incur further displeasure. The foxes soon returned and, discovering the geese, removed them, leaving only the legs sticking in the sand. Wisagatchak discovered his loss upon awakening and, in his anger, heated a large stone and pressed it against the offending side. As it began to burn with a hissing, chee, chee, he exclaimed, "Oh yes, I will make you sing chee-e-e-e-e, chee-e-e-e-e, for allowing all my geese to be stolen."

As he went along, while the wound healed, a piece of dried flesh fell at his feet. Not noticing whence it had come he picked it up to eat it. Kitche Ganeseesuk flitting about among the bushes called out, "Wisagatchak is eating his own flesh." Throwing the piece in his hand against a birch tree he exclaimed, "Let that be called pusagun (touchwood) forever."

\section{WisagatchaK's Adventure with the Beaver.}

One day, as Wisagatchak was going along, he came upon a beaver which was cutting green cottonwoods for food. Seeing him approaching the beaver sank down, feigning death.

"Why do you not work?" said the manito. Receiving no answer, he concluded that the animal was dead. He then fastened a line about its neck and hung it over his shoulder, having to take off his fire bag to make a place for it. The fire bag was disposed of by being tied to the beaver's tail. When he reached a suitable camping place the manito built a fire and went to cut four sticks upon which to roast the four quarters of the beaver. During his absence the beaver escaped. Hearing it splashing in a creek near by he rushed back and discovered its flight.

"My fire bag! Give me my fire bag," he cried, but the beaver only laughed in reply. 
"My little brother, give me my fire bag," he again entreated. The beaver threw out the bag which lodged in a branch above his head. Wisagatchak saw the image of the fire bag reflected from the surface of the water and, mistaking it for the object, reached toward it, not finding it he plunged to the bottom in search of it; as he turned he caught sight of it in the tree. Angered by his mishap and planning vengeance upon the beaver he hastened to its lodge to await its return. After waiting a long time he fell asleep, in which condition he was discovered by the whole beaver family which covered him with mud and sticks up to his neck so that he was quite helpless.

"Now, we will waken him by scratching his face," said his tormentors, who eluded his pursuit, when he had worked himself free, by dashing away into the muddy waters of the lake.

\section{The Magic Arrows.}

As Wisagatchak was going along, he came upon a lodge whose only occupant was an old wife who informed him that she lived with her four sons, who were then away hunting. They returned in the evening, carrying their arrows with their points uppermost. The young men said nothing, but left the camp next morning again in search of deer. Wisagatchak's curiosity was aroused by their conduct so that he stayed until evening, when they returned, carrying their arrows in their hands and having each a deer's heart upon his back.

"My sister, I should like to have arrows like those," said the manito; at the request of their mother the hunters gave Wisagatchak a handful of the magic arrows and allowed him to accompany them upon their hunting trip the next day. They instructed him in the manner of holding the arrows, that when the heads were pointed upward the person holding them was borne swiftly through the air; when they were pointed toward a deer, both arrow and hunter passed through the body of the animal. Wisagatchak was so successful with his first attempt that he declared, "I will go hunting alone, now."

"You will kill yourself if you miss the ribs," said the others, as he left them.

He soon discovered a large moose and, not heeding the warning, pointed his arrows at its head against which he crashed, killing the moose and stunning himself. When Wisagatchak 
did not return the old wife was much concerned and sent her sons to search for him. They soon found him and by blowing (formerly the principal "medicine" of Northern Indians, vide Hearne) restored him.to consciousness and brought him back to their lodge. As they mended the shattered arrows he recovered; when they were quite perfect he was well and strong again.

The young men had a quiver for their arrows which Wisagatchak coveted. That night he stole it and fled. When he laid down to sleep, at last, he kept the quiver in his grasp. Toward morning he was awakened by the old wife who said, "You have been stealing."

Much to his discomfiture, he found himself once more in the lodge. The next night he again took the quiver and went away a long distance. Instead of lying down to sleep he tied himself to a tree. He was awakened at daylight by the words, "You have been stealing again," and he found himself tied to a tree before the lodge. The woman advised him to ask for the quiver. He did so and it was given to him. He then set off upon his travels once more. As he was going along, he discovered an Indian camp toward which he crawled. Its inhabitants caught sight of the manito, and fired upon and nearly killed him. He remembered his quiver of arrows in time to save himself by flying through the camp.

\section{He Becomes Blind.}

As he continued his endless journey, he heard someone calling for his eyes, and he came upon a medicine man who threw his eyes into the air, shook his staff at them, and called upon them to return.

Wisagatchak, of course, was anxious to acquire this power, and asked, "Why do you do that?"

"That is the way I treat them when they are sore," was the reply of the magician, who readily divulged the secret to Wisagatchak. He was cautioned not to attempt the feat unless his eyes really needed treatment. He soon forgot the warning and exercised his new power with success.

"That is my trick now," said he laughing to himself. Pretending that his eyes were sore he again cast them from him, but instead of returning the eyes fell far beyond his reach. As 
he crept about on his hands and knees searching for them, he was discovered by a fox which caught up a stick and thrust the end into the empty eye-sockets of helpless Wisagatchak, caushim to cry out with the pain. The fox was delighted with its success and tried again, but the manito succeeded in catching it.

"Now, I will kill you," said he.

"Why do you not keep me, and I will lead you about?" asked the fox. Seeing the wisdom of this, he spared the life of the fox and continued his journey holding to its tail. Wisagatchak soon tired of that manner of traveling and told the fox to bring him some clear spruce gum. When he obtained this, he shaped two pieces for eyes; after rubbing them a few times he was able to see a little. Again he rubbed until his sight was wholly restored. He then released the fox, saying, "Now, make your own living."

The fox ran off and soon fell asleep upon a grassy point which projected into the lake. Wisagatchak fired the grass and the fox perished in the flames.

\section{END OF WisagatchaK.}

Continuing his wanderings he fell in with a family of bad Indians, from whom he endeavored to escape, but was pursued by muskrats, employed by his enemies to bring him back. Wisagatchak blew upon the muskrats driving them back, saying, "Go, build lodges for your children, and wherever there is a people they shall know where you live and shall use your skins." And the muskrat builds its lodge and is killed for its fur down to the present day.

But the rats drove Wisagatchak out of this country. The narrators of the legends all agreed that this was his last adventure in America.

\section{ANIMAL MYTHS.}

\section{The Moose and the Hare.}

A hare accosted a passing moose one day with the remark, "You are proud."

"I am no prouder than you are," was the reply.

"Yes, you are, for 1 go into any snare; even a woman's garter will catch me. I serve as food for a great many."

"I am more benevolent than that, for when a man kills me he has a great deal of meat." 
The Moose and the Jackfish.

As a jackfish was lying with its back out of the water, a moose came down to the stream to drink.

"You look very proud," said the jackfish.

"You, also, look very proud," replied the moose.

"Oh, no! I am kind-hearted; I allow the women and children to catch me, and I keep them from starving. But you are a coward. You run away if you see a man's track in the bush."

The moose was angry at this, and struck the fish upon the head with its forefoot.

"Your head shall always be shaped like my hoof," said he. And so it is to this day.

\section{The Owl and the Cascade.}

Pafunagesup, the little owl, was the husband of Wahpenao, the ptarmigan, and brother of Ohomashoo, the night owl. Pafunagesup was going along, when he came upon a cascade. Perching upon a lofty branch of a dead tree, he said to the waterfall, "We shall see who can call the longer."

The fall stopped and answered, "Oh, no, my little grandchild, you will never call as long as I; for I shall call as long as the world shall stand."

"Never mind, I shall call the longer, anyway," said the vainglorious little pafunagesup, as he began his cry. Soon the cascade again stopped to remonstrate. "My little grandchild, it is of no use for you to continue, for I shall never stop."

But the owl would not desist. After a long time, the cascade again ceased its roaring. "Aha! I told you that I would call longer than you," said the owl.

"No, I only stopped to warn you, for the last time, that I shall call forever;" and again they continued. Little pafunagesup called and called, until his head dropped off, and his neck was all worn away, which accounts for the apparently headless condition of the bird to this day.

How Sea Water became Unfit to Drink.

At the beginning, all the small fur-bearing animals were in constant fear of their lives, owing to the existence of a very large skunk which preyed upon them. They at last gathered 
to hold a great council to consider ways and means by which they might rid themselves of the common enemy. It being reported that the dreaded monster was approaching, the mink was sent out to reconnoitre. Catching sight of huge footprints in the distance, the mink, fearing to run across the crust of the snow, dived beneath it and burrowed his way to the track. He recognized it at once and hastened back to give the alarm. The assembly fled in a body and did not halt until they had passed through a narrow defile in a lofty range of hills. The carcajou then climbed a tall tree, and reported, "From here I can see a lake. There is a point extending into it and enclosing a bay shaped like a beaver house. Let us go out on the lake, and turn back into the bay, there the lynx and I will kill our enemy the secak."

In the meantime, the secak had been disturbed at the time the mink came upon his trail. Turning back upon the track, he soon came upon the footprints which the mink had discovered. Divining the cause of the tunnel under the snow he followed it to the deserted camp, where he found an old marten which had been deserted by the frightened counsellors. The marten taunted him, saying, "You are sharp-nosed, you have narrow bony jaws. All of the other animals run away from you, because you are so ugly."

"My grandmother, here is a little hair-grease for you," said the secak, throwing some of his mephitic oil upon, and instantly killing, the old marten He set off upon the track of the fleeing multitude, following them until he came out upon the lake, where he was seen by the pursued. His tail appeared like a great sail and the ice cracked beneath his tread. The carcajou, having taken command, concealed his forces under the snow and dug tunnels that they might communicate with each other. The secak came up to the carcajou, which was sitting beside one of the holes: "Why do you all run away across the hills?"

"We are afraid of such an ugly brute as you," replied the carcajou, diving into the snow, as the angry skunk strove to cover him with its oil. The carcajou came up through one of the numerous passages, and laid hold of the secak from below, crying, "I have him! Come, everybody! Strike him! Spear him!"

They all came pouring forth from their hiding places, bring- 
ing ice-chisels and other weapons. The carcajou called for the lynx, which had wandered away, but was returning upon hearing the uproar. Mounting an overhanging branch, he surveyed the situation and wondered what made it so smoky. At last he was able to distinguish the secak through the haze. Leaping upon the monster's back he began to bite and scratch. He was caught and his legs were bent, as they are to this day.

At last, the secak was killed. The carcajou, totally blind and covered with the vile odor, asked, "Where shall I wash myself?"

"Go to the big water. Go to the sea. If you wash here it will spoil our lake."

They showed him the right course, and he set off to find the great water. "What tree are you?" said he, catching at a stick now and then as he passed along. One replied, "I am a pine that stands on the high ground."

Another said, "I am a birch that grows in the valley." And at last, "I am a willow that grows by the sea." Then he knew he was near his journey's end. Plunging into the water he cleansed himself thoroughly. Hence the pollution of sea water, which renders it unfit to drink to the present day.

The carcajou started homeward, loudly proclaiming his triumph in song. A band of wolves heard him singing and said, "Let us frighten our little brother." So they hid themselves and as he was passing they suddenly sprang out upon him. The startled carcajou climbed a tree, but quickly descended when they assured him that it was only a trick. They then journeyed on together. The carcajou becoming hungry, an old wolf dispatched the younger ones after a moose whose track they crossed. They soon found and killed their game. After eating the meat, an old wolf remarked: "I am going to make grease of the bones and you must not look to see how it is done."

He was grinding up the bones to get the marrow, when the carcajou, unable to restrain his curiosity, opened his eyes a little to peep at the performance. Scarcely had he done so when he received a terrific blow in the face which flattened it; and so, as a reward for his curiosity, it remains to this day.

The other animals held a council after the departure of the carcajou to consider what should be done with the carcass of the secak. They finally decided to cut it up and scatter the 
pieces all over the world for fear it might regain its life. This was done; and accounts for the small size and wide distribution of this pretty but unsavory animal.

\section{Teena's Story.}

Teena was an old Loucheux, who lived at McPherson. Some time after the establishment of the Anglican mission he called on Archdeacon McDonald and related the following:

"I have been out hunting. I had no luck away there, but as I was crossing a small prairie I saw a little smoke before me, which seemed to move away as I went on. I found it strange, but kept on, thinking what a fun to have a camp ready made. At last I came up, and found to my suprise that it was the devil who was sitting before the fire.

" 'Can I camp with you?' said I.

“' 'Yes, lay some brush for yourself there,' said he.

" 'I have no luck of late in hunting,' said I.

". 'It is the same with me,' said he. 'Ever since the mission was started I have had no luck at all here. I have been around two or three days this trip and have no one yet." 
NATURAL HISTORY 



\section{MAMMALS}

THE primary object of the expedition was to collect mam1 mals, especially the larger ones, and birds. There was little time to follow other lines of investigation, which would have received attention by a better equipped and larger party. Previous experience had taught me that "the only way to collect is to collect," which induced me to spend every available hour in the field.

A great deal of labor was required which did not directly advance the scientific purposes of the expedition; a month's time was lost in Winnipeg, weeks and months were spent in traveling.

The region traversed extends from the Saskatchewan River to the mouth of the Mackenzie, and from Lake Winnipeg and Bathurst Inlet to the Rocky Mountains, embracing an area of nearly a million square miles.

The Indians and Eskimos that inhabit this vast territory are carnivorous beings. They are provided with firearms, with which they kill nearly every living thing which it is in their power to destroy, without mercy or discrimination. Most of the mammals here considered have a commercial value at the trading stations, either for their flesh or skins, or both. There are about fifteen species of the order carnivora, also preying upon the animal life of the region. "It is a country of death."

Throughout the valleys of the Peace and Saskatchewan Rivers there are more or less extensive prairies. But the country in general is wooded, except the Barren Ground, which occupies the northeastern portion of the continent, beyond the line drawn between the mouth of the Churchill River, and Richards Island at the mouth of the Mackenzie. ${ }^{1}$ This limit of forest growth corresponds closely to the summer isotherm of $50^{\circ} \mathrm{F} .^{2}$

1 See Report on the Forests of North America,' by Chas. S. Sargent, Tenth Census of the United States.

seebohm, Henry, in the Geographical Fournal, London, Vol. II, p. 337. 


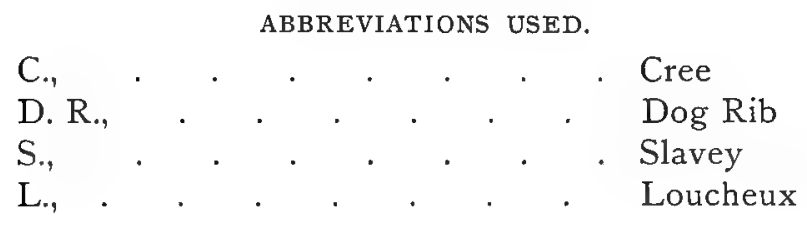

Cariacus macrotus (Say).

Mule Deer.

This species is now becoming rare in Alberta among the eastern foothills of the Rocky Mountains. One specimen, the head of a male, with large antlers.

Rangifer tarandus caribou (Kerr).

Woodland Caribou.

Tän-tž̆, D. R. Be-tsĭ, S.

The antlers of this species which $I$ have seen have a flatter beam than those of the Barren Ground caribou. They are never symmetrical. I obtained a pair from an old medicine man near Cedar Lake, who had kept them because of their symmetry, which, however, was not perfect; the brow tines are heavy and slightly palmated, the bez tines are flat and broad, but not expanded at their points, and are proportionately larger than in the other variety of caribou.

Southwest of the Great Slave Lake we frequently came upon their trails on the small prairies, where they had plowed up the snow over considerable areas in their efforts to reach the grass.

They are usually found in bands of four or five. I was told by the Indians that they did not occur east of the Northern Arm of the Great Slave Lake, but west of it, on the traverse between Rae and Providence. I crossed several of their trails between Birch and Lion Lakes. The woodland caribou is unknown at McPherson.

Their skins are said (by Richardson) to be infested with gadfly grubs, as are those of the Barren Ground caribou, but the dressed leather traded at Grand Rapids and Resolution showed no trace of grub holes. The leather made from their skins is nearly as heavy as moose leather but, as I learned from sad experience, without its wearing qualities.

The flesh is traded by the Indians, who receive $5 \mathrm{MB}$ for a whole caribou, and from 3 to $6 \mathrm{MB}$ for a dressed skin. 
They occur in the wooded portions of this region south of the Great Bear Lake.

Represented in the collection by a fine pair of antlers from the Saskatchewan.

Rangifer tarandus (Linn.).

Barren Ground Caribou. ${ }^{1}$

Ek-wo', Wĕ-tsi, D. R. Vŭth-zi, L. No-ti, S.

The Barren Ground and woodland caribou are the only American cervidæ which have antlers in both sexes. These are shed so irregularly that some individuals in a herd may be seen with them at any season. The new horn begins to grow late in April. It had just appeared on the heads of the caribou which we killed at the termination of my musk-ox trip. The velvet is not all cleared off until November. The old males are the first to shed their antlers; some of those which I secured late in November would probably have cast them very soon, as they broke away easily in handling the heads. While in the Barren Ground, in March and April, I saw large numbers of both sexes with antlers, and on the fifth of April killed a buck, four or five years of age, still bearing them. One of those collected in November, 1893 (No. I0,802), a male of two years, carried simple spikes, I 8 inches in length; 2 inches above the head they are flattened laterally and curved backward. The terminal third curves upward and inward and is again compressed obliquely; the greatest spread is 13 inches. The antlers of No. I0,8I I have a spread of 3 feet, and are 3 feet 7 inches in length. One brow tine is a spike, the other a plow, $8 \mathrm{r} / 2$ inches in width. The bez tines resemble a half closed hand. The crown contains 4 points on the right and 5 on the left side. Another large male (No 10,808), has antlers fully as long as those of the preceding but with a much heavier beam and with palmated crown tines.

The Barren Ground caribou is called the reindeer, caribou, or, most commonly, deer, in the North. It is provided in summer with a covering of soft hair, not exceeding an inch in length, of a uniform brown above and a lighter shade on the lower parts. The natives hunt them in August and September for their skins which are then in their best condition for being

1 See p. 88, ante. 
made into clothing; later the long, coarse hair of winter appears, which is heavy and easily broken. Their color in winter-roan -readily assimilates with the gray-hued, moss-hung pines.

Albinism is so rare among them that old Dog Ribs assured me that they had never seen a "white deer." Yet I secured an excellent mountable specimen (No. 10,820) which had been killed by the Yellow Knives, who hunt northeast of the Great Slave Lake. This animal, an adult male, was entirely white, except the head, which was but little lighter in color than it should have been in a normal condition. They feed in winter upon dried grass-I have seen acres of snow pawed over in search for it-and the cream colored "reindeer moss" (Cladonia rangiferina), one of the commonest lichens on the hills of the region.

The caribou are gregarious, ordinarily ranging in bands of a few score, but during their migrations gathering in vast herds containing thousands of individuals. They seem to have moved eastward, as they have entirely deserted the timbered country along the Mackenzie River. They are not abundant in winter around Rae, where they were killed by hundreds ten years ago. Only one small band crossed the lake toward the west during the winter of $1893-4$. Thousands remain in the Barren Ground with the musk-ox, never reaching the timber at all; the others gather in immense herds in October when they enter the woods and work southward as far as the Great Slave Lake, Lake Athabasca, and Reindeer Lake. North of the Great Slave Lake between longitude $109^{\circ}$ and II $8^{\circ} \mathrm{W}$., the greater part of those which enter the timber are massed together into a single herd, which is so erratic in its movements that the Indians, who depend entirely upon the caribou for food, are often reduced to the verge of starvation. They move against the wind so that the direction-whether toward Rae or Fond du Lac- depends upon the prevailing winds during the last fortnight in October. In March they return to the edge of the woods. It is said that only the females reach the sea coast, where they drop their young in June, but I have seen both sexes wading in the shoal water of the Arctic Ocean, south of Herschel Island, in July.

West of the Mackenzie they are still abundant along the barren coast and in the mountains south of it. They migrate 
southward in autumn, but how far, is not known. Rampart House was a "deer post," being situated in a pass traversed semiannually by the caribou.

The whalers reported that the caribou were abundant among the islands between the mouth of the Mackenzie and Cape Bathurst in July, I894. They also declared that they saw steam arising from hot springs around which the natives say that the caribou become mired in quicksands.

Hearne has described the habits of this species and given an account of the method of capture. The Copper Indians of that time built large pounds into which the caribou were driven and captured within the enclosure by the use of snares. One of these snares (No. I0,839), which I obtained from the Dog Ribs, is 9 feet in length and made into a hard line .25 inch in diameter from 6 twisted strands of babiche. During a year's stay in the country I saw but two such snares; their use has been practically abandoned by the Yellow Knives and Dog Ribs of the present day. At the time of Hearne's visit the caribou were also killed with spears made of copper from the Copper Mountains. At the present time thousands are slaughtered by being speared in the back while swimming across the long narrow lakes which are so abundant in the Barren Ground. The spears are now made from old files which are drawn out into a shank 8 to $\mathrm{I} 2$ inches in length, with a diamond shaped head $I$ inch in width (see specimen No. 10,843). Hundreds are killed from a single band in this way; the light canoes surround them, the bewildered creatures are herded together until within reach of the long, slender spears, a single thrust of which is sufficient to kill.

In winter they are now hunted with muzzle-loading trade guns. When the caribou are wary and few in number, the hunter pursues them upon snow-shoes, stalking if the contour of the country permits. When they are abundant, the hunter takes his stand at the margin of an ice-covered lake upon which converging lines of pine brush, laid at intervals of fifteen or twenty yards, have been placed; the caribou will not cross the lines but approach the concealed hunter, who usually kills several before the band makes off. On one occasion two frightened caribou approached my line at full speed; when they caught sight of it they stopped, turned back and again 
came on, advancing each foot cautiously, as if trying unsafe ice, until past the barrier. When I hunted them with dogs, I could but pity their stupidity; when a mile from their pursuers, with the woods and safety near at hand, they often turned abruptly and came flying back into danger.

The Barren Ground caribou is of great value to both the Indians and Eskimos. Some bands of Crees, Chippewyans, Caribou Eaters, Yellow Knives, Dog Ribs, Slaveys, Hares, Loucheux, and Rat Indians depend almost entirely upon them for food and skins for lodges and clothing. Every part of the animal is utilized; the antlers, before the advent of the whites, were used for ice chisels, the name for this tool and horn being the same in the Dog Rib language; later, they were bored out to make powder flasks, but are now discarded with the hoofs. The flesh, including portions of the intestines, the feet, tendons, and blood are eaten. The tongues were formerly dried and salted for export by the Company. The unborn calf, the udder of a milk-giving cow, the tongue, the marrow, and the back-fat are the parts held in highest esteem.

Although I lived for two months with the Dog Ribs and spent a year in their territory, I never saw them eat the contents of a caribou's stomach, ${ }^{1}$ though I have frequently seen them empty the stomach to use it as a receptacle for containing the blood. until frozen.

A gadfly (thought to be Hypoderma lineata by Dr. Riley, but in the absence of specimens it is uncertain) deposits its eggs. in the backs of the caribou, in some individuals to the number of several hundred, which renders the skins utterly useless for leather. The grubs were well developed in the latter part of April when I left the Barren Ground. The Indians did not remove them from pieces of meat destined for the kettle. Hearne says of them:2 "The Indians, however, never could pursuade me to eat the warbles, of which some of them are remarkably fond, particularly the children. They are always eaten raw and alive out of the skin and are said by those who like them to be as fine as gooseberries." Richardson writes: "It is. worthy of remark that in the month of May a very great number of large larvæ exist under the mucous membrane at the:

1 Compare Hearne, Fournal, p. $3^{16}$.

Ibid, p. 197 . 
root of the tongue and posterior part of the nares and pharynx. The Indians consider them to belong to the same species with the oestrus that deposits its ova under the skin; to us the larvæ of the former appeared more flattened than those of the latter." This variety of caribou is found only in the Barren Ground, in summer; hence it occurs only along the northern and northeastern border of this region.

They are becoming restricted in their range east of the Mackenzie, but after seeing them in their thousands in the Barren Ground, it hardly seems possible that they will be exterminated for many years to come as none are killed by white men, except a few by whalers or exploring expeditions, owing to the comparative inaccessibility of the territory which they inhabit. The Eskimos are driving them from their hunting grounds by the use of repeating rifles. The Indians are also beginning to use improved weapons with disastrous effect.

Ten specimens, seven skins and two heads at Rae; one albino from Fond du Lac, Great Slave Lake.

Alces machlis (Linn.).

Moose.
Mus-wa, C.
Tĕn-di, D. R.
Tiñ ${ }^{-g i k}, \mathrm{~L}$
Co-lŏn ${ }^{n}$, S.

I have followed the classification of Flower and Lydekker who consider the American and European elk as varieties of a single species. The large size of the moose and its imposing antlers has made it a favorite subject for the taxidermist, yet the ordinary mounted specimen gives us but an imperfect idea of the grandeur and majesty of bearing of the moose in its native forest-the moss-hung conifers of sub-arctic regions. The great palmated antlers without brow or bez tines, the long slim legs, and the pendulous lip but add to its homeliness, when removed from its natural surroundings.

The moose when alarmed makes off at a shambling trot which is said to be swift enough to soon distance a man, yet in September, I892, I ran in pursuit of a three year-old moose that had been thoroughly frightened, upon which I gained a hundred yards in a half a mile and which I succeeded in killing. Hearne states that, "Of all the large beasts in those parts the buffalo is easiest to kill and the moose are the most difficult." 1 Having successfully stalked them in September and

1 Fourney, p. 254 . 
October, both with and without Indians, I am satisfied that a white man can secure them without the aid of natives. They are killed along the rivers from the decks of steamers, which they will allow to approach within rifle range. In winter they are stalked as in summer, though when the snow is very deep they are said to be pursued by runners upon snow-shoes. During two winters in the north I knew of no instance where they were so hunted. From two to five are usually found together, and it is very seldom that the Indian hunter does not succeed in killing more than one of them.

The flesh of the moose is preferred to that of the caribou, whether fresh or dried. Moccasins, gloves, mittens, coats, lodges, harness, gun covers, sled wrappers, boats, etc., are made from the skins. Thread is made from the sinew of the back, and skin scrapers from the long bones. From 2 to 5 dollars is paid for a dressed skin and about half as much for the meat.

Mooseskins are supplied to all Company's posts, where the moose are not found, from which to make moccasins, etc., for officers and servants.

The moose is found throughout the wooded portion of this region and even beyond the timber line among the willowcovered islands of the Mackenzie Delta. William Flett, the interpreter at Fort Smith, one of the most intelligent of the Loucheux, declares that the moose west of Rampart House (abandoned 1893) have hoofs like the mountain goat. They are said to be very numerous and easily approached in the mountains west of Norman.

McConnell speaks of the region between the Devil's Portage and Hell Gate on the Liard River as "probably the best moose country in North America." 1 They are common west of the Northern Arm of the Great Slave Lake but rare east of it. ${ }^{2}$ The Indians assert that this is due to the presence during a part of the year of the Barren Ground caribou. I think it quite as likely that the absence of proper food for a browsing animal may account for such distribution.

Sir Alexander Mackenzie states that, in 1789 , moose were not found north of the mouth of the Liard River $\left(6 \mathrm{I}^{\circ} 34^{\prime} \mathrm{N}\right.$.); this

1 Ann. Rep. Geo. Sur. of Canada, Vol. IV, p. 46.

2 According to King they have been found as far to the northeast as the Fish River, east of the Great Slave Lake. Narrative, Vol. I, p. Ig2. 
must have been an error as they were common throughout the Mackenzie valley in the early part of this century upon the advent of the traders. The Loucheux of the lower Mackenzie have a tradition that the moose have migrated from the westward. Three specimens, Grand Rapids.

Bison Americanus Gmelin.

BUfFalo. ${ }^{1}$

The wood buffalo, or-to use a more exact term-woodland bison, is described as larger and darker than the buffalo of the plains; this I believe to be partly due to the fact that our knowledge of the northern variety is based on the study of skins taken at the most favorable season of the year and under circumstances which would cause the largest animals to be killed. The herd at present consists of a few hundred only. They are so wary that but one effective shot can be fired when they betake themselves to instant flight, and, as with the moose, pursuit is altogether futile. They cannot be hunted in summer as the country which they inhabit is an impenetrable, mosquitoinfested, wooded swamp at that season. The Little Buffalo River is unfit for navigation and the lakes and ponds cannot be utilized as water routes. They can only be killed by stalking in midwinter when their pelage is at its best.

There is an abundance of grass on the "little prairies" and on the borders of the small lakes which everywhere abound; this, of course, must be uncovered by the buffalo in winter as they do not browse. Ogilvie states ${ }^{2}$ that twenty-eight years ago a heavy fall of rain in one of the winter months saturated the snow, which formed a heavy crust of ice and prevented the buffaloes from grazing, which resulted in their almost complete extermination.

The Indians along the Peace and Slave Rivers make occasional trips into the buffalo country with dog teams to establish lines of marten traps. When they discover a band of buffaloes they of course kill as many as they can, but they have not made systematic efforts to hunt them for their robes, as they have the musk-ox. Fortunately, the officers of the Company have exerted their influence toward the preservation of the buffalo, not trading for the robes, until the recent advent of rival traders.

1 For description of buffalo hunt, see p. Ioo, ante.

2 Ogilvie, William, Ann. Rep. Geo. of Canada, Vol. -, p. 39. 
During the winter of $1892-3$ forty buffaloes were killed, the largest number that had been secured for several years. I saw most of these robes which were very dark, the hair thick and curled, making a robe superior to that of either musk-ox or plains buffalo; they were so large that the Indians had cut many of them in halves for convenience in hauling on the sleds.

From 20 to roo MB are paid for the robes. The traders are trying to induce the Indians to preserve them as mountable skins.

The northern limit of the range of the buffalo, as given by Mackenzie, was the Horn Mountains, north of the Little Lake. Père Ruore, of the Saint Michel Mission at Rae, who has crossed the Rae-Providence traverse several times, assured me that he had seen buffalo skulls on the prairies which lie within fifty miles of Providence, northwest of the western end of the Great Slave Lake. I saw no remains of buffaloes when I crossed these prairies in December, owing to the snow, but the country is similar to that south of the lake where they are still found.

Black Head, an old Yellow Knife chief, living at the mouth of the Rivière au Jean, told me that he had killed "plenty of buffaloes" in the delta of the Slave River. About fifteen years ago a few were killed near Liard, but they are seldom seen in that quarter. They formerly frequented the "Salt Plains," forty miles northeast of Fort Smith. Franklin's party killed a buffalo in that vicinity at the time of their visit in $1820 .{ }^{1}$ Richardson states that in 1848 there was an abundance of deer and buffalo meat obtainable on the Salt Plains. ${ }^{2}$

They are at present confined to the neutral ground between the Chippewyans and the Beavers.

The Rev. C. G. Wallace, in 1892 , found the skull of a fossil buffalo ( $B$. antiquus?) on the Porcupine River, and others have been reported from the Yukon valley.

The collection contains a very large skull of the plains buffalo, which was secured at Pincher Creek, Alberta.

Ovibos moschatus (Blainv.).

MUSK-OX
Ět-jı̈r-er, D. R.
Ǔk-ki, L.
Ota ĕt-jŭr-ĕr, S.

The musk-ox is a short-limbed, heavily-built animal, weigh-

I Franklin, Sir John, Narrative, p. I77.

- Arctic Searching Expedition, p. I49. 
ing, according to Parry, about 700 pounds; the head and hide I 30 pounds. ${ }^{1}$

The pelage in winter is much darker than it is in late springthe season during which they are hunted for their skins. They are nearly black on the head, neck, and sides. The back is of a dark seal brown except an oval patch, a foot in length, over the lumbar region. This "white spot" is the only part of the body where the under wool is not hidden by the longer hair. It is of a dark chestnut underneath but bleached to cream buff on the surface. The long hair of the flanks is black with a lighter brown intermingled. The legs, below the "knees," are protected by short hair only, pale grayish in color. The long hair of the hump is curled and about 8 inches in length. The coarse outer hair on the other parts is straight, attaining a length of 20 inches on the throat and over 30 on the flanks.

The Barren Ground, which they inhabit, is a vast area of rugged hills; most of them are boulder-strewn, with mosses, lichens, and occasional plots of short grass on slopes that have not been denuded of soil; in places, high, rolling hills of gravel occur. We invariably found the musk-ox among the boulders at the summits of the highest hills. These rocks afforded but partial concealment, however, as the color of the musk-ox is too dark to assimilate readily with its surroundings at any season. They probably frequented the hill tops because the high winds, which prevail in that region, sweep away the snow, enabling the animals to graze with little digging.

There are usually twenty or thirty in a band, but they sometimes assemble in herds containing over a hundred. Hearne states that, "there are only two or three males in each band which is under the leadership of an old bull." In one band of eleven which we killed there were eight males; in another, in which twenty-five were killed, there were only two females, and from this herd I shot four bulls which broke away from the dogs together; all were of the largest size and evidently quite old.

The musk-ox presents an imposing appearance with his huge, shaggy head and formidable horns. The thick coat exaggerates his size; the erect mane gives the appearance of a large hump which in reality only rises $2 \frac{1}{2}$ inches above the line of the back.

'Supplement to App. to First Voyage, p. Igo. 
The length of one of the males (No. 10,775) from end of nose to root of tail exceeded 7 feet. The circumference of the body next the fore legs, after the skin had been removed, was 64 inches; depth of chest, 26 inches; circumference of neck, 30 inches; of fore leg next the body, ${ }_{5} 5$ inches. The measurements of the four large males referred to above varied but a trifle.

The horns of the males are expanded and flattened until they cover the crown of the skull for a distance of 10 inches back of the eyes. They have a spread (No. 10,775) of 26 inches and a total length of 29 .

The orbital ring is very prominent, projecting $2 \mathrm{x} / 2$ inches from the maxilla, thus carrying the eyes beyond the thick woolly covering of the head. In skinning the heads I found a mass of matted hair and dirt tightly wedged under the horns against the side of the head. The horns are not united in the oldest bulls, but are always separated along the median line by a space of a quarter of an inch which is filled by fine, grayish hair.

The flesh, in April, was well flavored without the slightest perceptible taint of musk. The animals from which it was taken were very fat; the fat itself was clear white, sometimes with a tinge of azure. Major Fielden says, " "The cause of the disagreeable odor which frequently taints the flesh of these animals has received no elucidation from my observations. It does not appear to be confined to either sex or to any particular season of the year; for a young, unweaned animal, killed at its mother's side and transferred within an hour to the stew-pans was as rank and objectionable as any. The flesh of some of these animals of which I have partaken was dark, tender, and as well flavored as that of four-year old Southdown mutton. * * * Leaves and stems of willow, with grasses, were in the stomachs I examined." Richardson observes, "that when the animal is in good condition the odor of musk is not noticeable, but when lean both bulls and cows smell strongly of musk." The marrow is large and white in the heavy leg bones, and is highly prized by the natives; they are also very fond of the fœtal calves, which by the middle of April seemed fully developed; the skins of these are purchased by the traders who have caps, etc., made from them; the hair is short, dark brown, and curled.

\pm Zoologist, Vol. I, 3rd Series, p. $35^{8}$. 
The Indians kill the musk-ox simply for the robes. The flesh is wasted, except an insignificant quantity which is consumed by the hunters and their dogs on the spot. They depend upon killing caribou on the way to and from the territory inhabited by the musk-ox, so that no meat is taken away. The musk-ox have been driven back so far into the Barren Ground that they are not now hunted in summer. The robes are trimmed nearly square by cutting away a broad strip along the breast where the hide is thick and the hair long; experience has taught the hunter that he will get $50 \mathrm{MB}$ for the robe be it large or small, so he cuts it down in order to make room on the sled for a larger number.

It is commonly supposed that the musk-ox form in a circle when surrounded by the dogs, which are released from the harness to chase and round them up. I had an excellent opportunity to observe their behavior on one occasion, when we approached within thirty yards of a dozen musk-ox, held at bay by as many dogs. They were in two groups about twenty feet apart, an old bull standing between them. They were not formed in a circle nor in two circles, but all turned toward any dog which ventured too near, seldom lowering the head but standing firmly, the head in line with the back. Two other herds, when pursued by the dogs, scattered in all directions; they would run a few yards, then turn to dash at the dogs as they closed in, repeating this performance until overtaken by the hunters to whom they fell an easy prey. Pike says, "There is an idea prevalent in the North that on these occasions the old musk-ox form into a regular square, with the young in the center, for better protection against the dogs, which they imagine to be wolves; but on the two occasions when I saw a band held in this manner, the animals were standing in a confused mass, shifting their position to make a short run at a too impetuous dog, and with the young ones as often as not in the front of the line."

The musk-ox was formerly common between the Mackenzie and Behring Straits, as evidenced by the remains which are scattered over the tundra. The oldest natives at Point Barrow say that their fathers killed musk-ox which were then abundant. Their present distribution is from the vicinity of the

1 Barren Ground of Canada, p. 104. 
Mackenzie north of the Great Bear Lake to Sabine Island $\left(74^{\circ} 45^{\prime} \mathrm{N}\right.$.) on the east coast of Greenland, and from $60^{\circ} \mathrm{N}$. in the Barren Ground west of Hudson's Bay through the Northern Islands as far as man has penetrated.

Five specimens killed near Bathurst Inlet.

\section{Ovis montana Cuv.}

Mountain Sheep.

I attempted to secure specimens of big horn in southwestern Alberta in April, I893, ${ }^{1}$ but was unsuccessful. I afterward learned that the Stoneys use dogs in hunting them at that season. Two specimens, a skull, and a head bearing horns $14 \mathrm{I} / 2$ inches in circumference and 32 inches long, weighing, without the lower jaw, 24 pounds.

Ovis montana dalli (Nels.). ${ }^{2}$

Alaska Mountain Sheer. ${ }^{3}$

The specimen of this rare animal, secured by Mr. Russell through the kindness of Capt. F. C. Murray, of Herschel Island, is an adult male in good condition. The pelage is coarse, like that of the common mountain sheep, but very thick and heavy, the individual hairs being $5-6$ inches long. The color is white throughout, with a yellowish wash on the forehead and in front of the tarsi.

The most conspicuous anatomical difference between this form and $C$. montana is in the shape of the horns, which are much more spreading in the former, one specimen showing a spread of $2 \mathrm{ft}$. $5 \mathrm{in}$. between the tips, and another $\mathrm{I} \mathrm{ft} .8 \mathrm{in}$. The common form shows a spread of only I ft. 5 in. and I ft. in the two specimens before me. The arctic specimens have much larger and more distinctly separated corrugations on the basal half of the horn than are found in the specimens of the southern form with which they were compared. The distal portion of the former is more conspicuously flattened than in the latter, and the proximal portion more distinctly triangular in cross-section. There is also a notable difference in the relative size of the hoofs.

The following measurements of mounted specimens will show

1 See p. 47 , ante.

2 Proceedings U. S. Nat'l Mus., Vol. VII, p. I2.

'These specimens having been received during the absence of the author, this description is contributed by the curator of the museum. 
the comparative proportions of $C$. montana dalli and $C$. montana, as represented by a good mounted specimen of each:

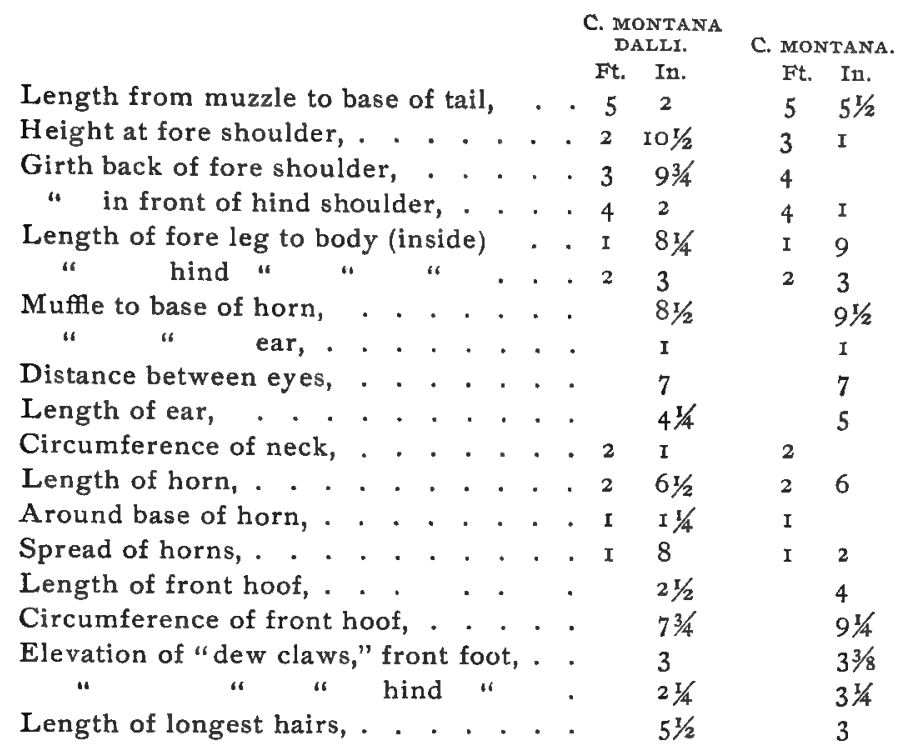

The above measurements show that var. dalli is a heavier and stockier form with more conspicuously corrugated horns having a greater spread, with much longer hair, shorter hoofs and less elevated "dew claws" than its southern relative.

A comparison of the skulls of these two forms does not disclose differences which may not be due to age or other purely individual causes.

C. C. N.

Haploceros montanus Rich.

Mountain Goat.

A head obtained from the Stoneys is among the specimens from Pincher Creek.

Putiorius erminea (Linn.)

ERMine.

Si-kwe-su, C.

Common throughout most of the region visited. The skins are purchased by the Saskatchewan traders for 5 cents each. I do not think that they are traded in the North. 
Seventeen specimens were secured; one at Rae, just assuming the winter pelage; three at Grand Rapids; and thirteen skulls from Cedar Lake.

Mephiticus mephitica (Shaw).

SKUNK.

Si-käk, C.

Common on the Lower Saskatchewan, where the skins are purchased by the traders for 50 to 75 cents. It is unknown to the Dog Ribs who have no name in their language for it.

One specimen, Grand Rapids.

Lutreola vison (Schreber).

Mink.

Säk-we-su, C. Tĕch-u, D. R. Chi-thă, L. Teh-u, S.

The mink is decreasing though still comparatively common throughout the wooded portion of this region; they are somewhat rare at the mouth of the Mackenzie. They are taken in "mink traps"-number I $1 / 2$ steel traps. The Dog Ribs, fearing the evil consequences which may ensue if a minkskin is kept in the lodge, always put them on a tree or scaffold outside.

The price paid varies from $\mathrm{I}$ to $3 \mathrm{MB}$.

One specimen in the collection, from Grand Rapids.

Mustela americana Turton.

Marten.

Wâ-p̆nn-ǐs-tän, C. Nŏh-we, D. R. Tsuk, L. Noth-ă, S.

The marten is the most abundant of the carnivores of this region. Five or six thousand are annually obtained at a single station.

They are much darker in the southern portion than they are north of the parallel of $6 \mathrm{I}^{\circ} \mathrm{N}$. They are also said to be larger in the southern districts, but I had no opportunity to verify this by an extensive series of measurements. I have never heard of albinos among them but I saw a light, tawny yellow skin at Simpson, which was received during 1893 .

They are sometimes caught in steel traps, but the greater part of them are caught in "marten traps"-simple dead falls. These are quickly and easily made and are quite as effective as more expensive traps.

The fur is not used by the Indians save for an occasional 
cap, but the sale of marten skins is the only source of revenue of many of them. They receive from $\mathrm{I}$ to $3 \mathrm{MB}$ for a prime skin.

The traders assert that the marten is subject to periodic murrains, as is the varying hare, but when these periods occurred and whether at seven year intervals they did not know. The marten is found throughout the wooded portions of this region. They are not decreasing in numbers except in some of the southern districts.

Two specimens, Crow Nest Pass.

Mustela pennanti Erx.

Fisher. ${ }^{1}$

U-tcek, C. En-e-i-won, D. R. No-tha-cho, S.

This species, usually called the Pekan in literature, is known in the North as the fisher. They are described by the trappers as "big black marten"; the Slavey name signifies "big marten."

They are caught in dead falls, similar to but heavier than those used for martens. Steel traps are also used.

Prime skins are worth from Io to I 5 MB in the country.

They are not common anywhere in this region. They extend northward as far as the Great Slave Lake, but are not found between Lake Athabasca and the Great Slave Lake except along the Slave River. They have been seen just north of the Mackenzie at Providence. A trader who has spent twenty years in the North assured me that he had seen but one fisher in the Mackenzie District and that one was taken at Lake Bischo in $188 \mathrm{I}$.

Lutra hudsonica ( $L a c$.).

OTter.

Nĕk-ı̆k, C. Nom-bä, Tcho, L. Nŭm-bä, S.

The otter is one of the rarest of the fur bearing mammals of the North.

I have seen an otter track in the snow near Rae in November far from open water.

The finest skins are said to come from the Peace River District. I was told by a former resident of Nelson (abandoned in 1893 ) that the otter was comparatively common there, but that the superstition of the Indians prevented them from killing the animal. At many other posts the natives prefer to bring

1 See p. I02, ante. 
the animal unskinned to the trader or, if they do the work themselves, the skin must be kept outside the lodge.

They are worth from Io to $15 \mathrm{MB}$.

The otter is found as far as the Arctic Coast but does not enter the Barren Ground. Hearne ${ }^{1}$ gives $62^{\circ} \mathrm{N}$. as its northern limit on Hudson's Bay.

Gulo luscus $S a b$.

Carcajou.

$$
\text { Kwi-kwe-ke-o, C. }
$$

This species is called in the North the carcajou, the name wolverine being almost unknown. The caracajou is cordially hated for his thieving propensities, which impel him to rob caches enclosed in frozen earth, beneath heavy stones, or in trees. The Crees engaged to travel from the Saskatchewan to Selkirk with me deposited fish at three places for use on their return. They cut a pit in the ice large enough to contain the fish, then broke a hole, through which the water rose, and soon enclosed the fish in solid ice; the snow drifting over it no sign of a cache remained to attract the carcajous or foxes.

The carcajou is too cunning to be taken in the ordinary trap but is sometimes caught in a modified form of the dead fall. Most of those secured are shot.

The skins are worth from 5 to Io MB in the interior, but along the coast they are more highly valued by the Eskimos who use them for trimming their skin clothing. The Eskimos pay the Loucheux and Rat Indians a higher price for the carcajou skins than do the traders. The whalers even bring the skins from San Francisco to trade to the Eskimos. The carcajous are decreasing in the southern part of this region throughout which they occur. They are common in the Barren Ground and I have seen them within fifty miles of Mackenzie Bay.

Felis canadensis Raf.

Canada Lynx.

No-tă, D. R.

Ni-chi, L. No-thă, S.

The lynx is said to have the same periodicity of increase as the northern hare upon which it preys. They should have been at their maximum during the winter of I893-4 but in the Great Slave Lake region, where I then was, the "pishew" or

1 Fourney, p. 374, 
"link" was by no means common. They are decreasing in numbers, but not because of the decrease of the hares. Districts which a few years ago received thousands of $l y n x$ skins now obtain but a few hundred. The Crees make a very warm and serviceable robe from the fur of lynxs' feet when the animals are abundant. The price varies from 2 to $6 \mathrm{MB}$.

They are usually caught in snares similar to those set for hares, but with a larger springe or a heavier weight. One which we passed in a York boat on the Athabasca River stared at us until we were within fifty yards before it thought best to make off. They occur in all the wooded portions of this region. They have been killed on the islands in the delta of the Mackenzie.

The flesh is white and is considered equal to that of the hare for food.

Canis lupus ( $\operatorname{Lin} n)$.

WOLF.

Mŭ-hi-kŭn, C. Ti-kă, D. R. Zo-tŭk-ĭ, white; Zo-rhĭ, black, L. Ti-kă, S.

They are not killed in considerable numbers anywhere, and the number of skins seen was too small to make any study of variation of color. At one Slave Lake post, only one gray wolfskin has been received during the last five years. In a band of half a dozen, which pursued me some distance in the Barren Ground, two were snow-white, the others were a light gray.

While in the Barren Ground we heard them nightly, howling about some musk-ox carcass, near our camp. On one occasion three of our party left their guns lying beside fallen musk-ox which they were to skin the next morning; during the night the wolves ate the gun-covers. One of our dogs, which ventured too far from camp, was devoured.

During the winter a large wolf was seen at Willow River, near Rae, trying to entice the dogs away from the buildings by its gambols. It kept whisking about as if in play, at the same time working farther away, followed by the younger dogs which were disposed to join in its sport and would soon have fallen easy victims had not the marauder been discovered. ${ }^{1}$

1 "These animals which are here large and formidable, often roaned at 
Wolfskins are purchased from the Indians for from 6 to Io MB.

Wolves are found throughout this region, but are not abundant in any portion visited except in the Barren Ground.

Canis vulpes Linn.

Fox.

Red, U-se-se-wŭk-ı̌s-u; Cross, —_ Silver, Su-nĭ-au-ŭk-i-su, Black, Kŭs-ki-iä-mŭk-e-su, C.

Red, Nŭ-ki-te-kwon ; Cross, Nŭ-ki-äk-lĕn-i-tzu; Silver, Nŭ-ki-wilân-di; Black, Nŭ-ki-te-zon, D. R.

Red, Ek-o-tso; Cross, Nĭn-ŭ-lri; Silver, —_ B Black, Ak-e-ř̆, L.

Red, Nŭn-kĭ-de-ço; Cross, Nŭn-ki-de-zon-be-ke-te-co-de-ze; Silver, Nŭn-ki-de-zon-be-ge-le-ko-te-ge; Black, Nŭn-ki-de$\mathrm{zo}^{\mathrm{n}}, \mathrm{S}$.

While I saw several hundred foxskins during my journey, I have had no opportunity to study either specimens or the literature concerning them sufficiently to feel justified in placing the fox in a separate genus from those admittedly belonging to the genus Canis. Flower and Lydekker state that, "The best cranial character by which the different members of the genus (Canis) can be distinguished is that pointed out by Burmeister, viz, that in the animals generally called dogs, wolves, and jackals the postorbital process of the frontal bone is regularly smooth and convex above with its extremity bent downwards whereas in the foxes this process is hollowed above, with its outer margin (particularly of the anterior border) somewhat raised."

I have seen litters of young containing both red and cross foxes. The natives assured me that they had found red, cross, and silver foxes in the same family. The skins show every possible shade of intergradation between these varieties. Among about fifty silver foxskins which I saw there were four which were practically black.

night amongst the buildings of the post." Dawson, Capt. H. P., Observations of the International Circumpolar Expedition, Rae, p. I3.

Franklin gives the measurements of one which was killed at Fort Enterprise, east of Rae, during the winter of I82I-22. It was 4 feet, 4 inches long, including the tail, 5 feet and 4 inches; height, 2 feet, to inches. Narrative, p. 655 .

-An Introduction to the Study of Mammals, p. 547. 
Lahonton, ${ }^{2}$ writing two hundred years ago, states that the black foxes "are very scarce and whosoever catches one is sure to sell it for its weight in gold." The Cree name for the silver fox signifies the "money fox." Rival traders have so impressed the Indians with the value of the black and silver foxskins that exorbitant prices are demanded; after receiving ${ }_{5} \circ \mathrm{MB}$, the fortunate hunter asks a sack of flour (40 MB) and other articles of trade as a "present." The value of a red foxskin, worth I MB, is sometimes enhanced by the use of soot or gunpowder to that of a black fox; such skins are traded at night, and the same trader seldom allows "Johnny Injun" to swindle him a second time, either with painted foxes, or mink with marten tails. The cross foxskins are worth from 5 to $15 \mathrm{MB}$ in the country.

The several varieties are all taken in steel traps (No. 2), which are buried in the snow, with scraps of frozen fish, meat, or grease strewn about them for bait. Those that have escaped by leaving a foot in the trap are exceeding wary, but I cannot agree with most writers in extolling the sagacity of this species which often allows itself to be caught in poorly concealed traps. They are frequently killed by means of strychnine. A red fox which had been poisoned near Rae, in January, I894, was dragged some distance by another fox, then buried in the snow and the covering well tramped.

They are certainly decreasing in number, though they still occur in all parts of this region. They are found along the barren Arctic coast, but they are probably not common in the Barren Ground. The Indians do not bring any foxskins to trade from that quarter. One silver fox was killed on Herschel Island during the winter of '93-4, while forty white ones were taken there that season.

One skull, Cedar Lake, and a complete skeleton from Rae.

Canis lagopus Linn.

White Fox. Wă-päk-e-su, C. Et-sĭm-bă, D. R. Ak-e-vĭ, L. Täl-i-yĕhn, S.

Traders in the Mackenzie valley obtain several hundred skins annually, yet they secure but a small portion of the great catch made along the Arctic coast. The number of blue foxes received by the Hudson's Bay Company in Mackenzie District

Memoirs of North America, Vol. I, p. 235. 
varied from none in 1890 , to thirteen in 1887 . The most of the arctic foxskins that reach the markets of the world are obtained from the Eskimos, who catch them in traps made of blocks of ice which no self-respecting $V$. fulvus would even approach. ${ }^{1}$

A young specimen (No. I0,885), probably of this variety, perhaps two weeks old, is of a uniform seal brown on the back and flanks and grayish white beneath. Another individual (No. 10,886), about half grown, is seal brown along the back, somewhat darker on the flanks and legs where there is an admixture of white hairs; the sides are a deep buff becoming white beneath. This animal was evidently about to assume the adult pelage as long hairs were beginning to appear. The two specimens were playing about a burrow on the. Arctic coast, where they were shot from the canoe as we passed. Taxidermists should note the fact that they are hazel eyed. ${ }^{2}$

The natives receive about a dollar each for prime skins.

They are more abundant than the other species of foxes in America but are said by the traders to be decreasing in numbers.

The white fox is widely distributed throughout the Arctic zone being frequently met with on isolated islands or ice floes. They occur along the northern border of the territory visited, their southern limit of distribution being the Great Slave Lake.

Three specimens; one winter skin from Herschel Island, and two young, Warren Point, July 5th.

Thalarctos maritimus Linn.

WHITE BeAR.

Sa-te-kĭ, D. R.

Chr̈-zi, L.

While at Herschel Island I was informed by the Eskimos that the "nanook" sometimes gathered in scores about the carcass of a stranded whale. The flesh of a polar bear, killed near the buildings, was all eaten except the liver, which even the dogs avoided. ${ }^{3}$ The skin was removed entire, that is, in such

1 Compare Parry, Second Voyage, p. I5I. "These animals were found to. be so stupid that they allowed themselves to be caught a second time in the same trap after they had escaped from the ship." Fifteen were caught. in four hours in a cask with a sliding door.

" "Eyes a clear light hazel." Lyon, Capt. G. F., Fournal, p. 74.

a Compare J. C. Ross: "The skin peeled from the body of men eating those killed at Fury Beach, also on Parry's Expedition the men's skin peeled on feet, legs, and arms after living several days wholly on two bears." "The Eskimos give the liver to the dogs." Appendix to Narrative of Second Voyage, p. 7 . 
a manner that it could be used as a natural history specimen, as are many of the skins now taken by the Eskimos. These skins are taken to San Francisco in salt, or as dried skins which have been stretched and scraped to remove the thick lining of fat. The natives receive from 5 to 15 dollars in trade for prime skins.

The polar bear occurs along the northern border only of this region. A few years ago one penetrated as far inland as McPherson-over a hundred miles - robbing meat caches and playing havoc among the dogs.

A skin and two skulls were secured at Herschel Island, and a large skin at Cape Tchaplin, Siberia.

Ursus americanus Pall.

BLACK BeAR.

Sas, D. R.

Soh, L.

Sa-tĕn-di-clĭ, S.

I met several hunters who had seen both black and brown cubs in the same litter, yet they recognize the fact that the brown form of this species is very different from that of $U$. horribilis. A great many bear stories were told, but in one instance only had a wounded animal of this species turned upon its pursuer. One clerk declared that he had "killed over two hundred black bears without one of them ever showing fight." In descending the Mackenzie we approached within two hundred yards of one before he became alarmed and made off. At nearly every trip of the "Wrigley" a bear is killed along shore from her deck, these wary animals not yet having learned the dangerous character of the huge shape which appears so seldom and approaches so swiftly.

Their flesh is highly prized as food and the grease serves a variety of uses.

In the northwest they are caught in log deadfalls with a heavy, crushing weight. The No. 5 steel trap is also used. In the Slave valley they are sometimes caught in snares. The line is passed under a root so that when the springe is released the bear is dragged down and strangled. They are being exterminated along the Saskatchewan and Peace Rivers, but remain unchanged beyond the Peace.

About fifty skins are traded annually at Resolution. The price paid the Indians varies from 20 dollars in cash in the Northwest to 20 or $30 \mathrm{MB}$ in the North. 
Mr. John Firth, for several years clerk in charge at La Pierre's House, states that there were no black bears in that vicinity. During the ten months spent at Rae only three were killed within a radius of twenty miles of the fort. They are frequently seen in descending the Athabasca River and along the Mackenzie below Wrigley. They do not occur in the Barren Ground.

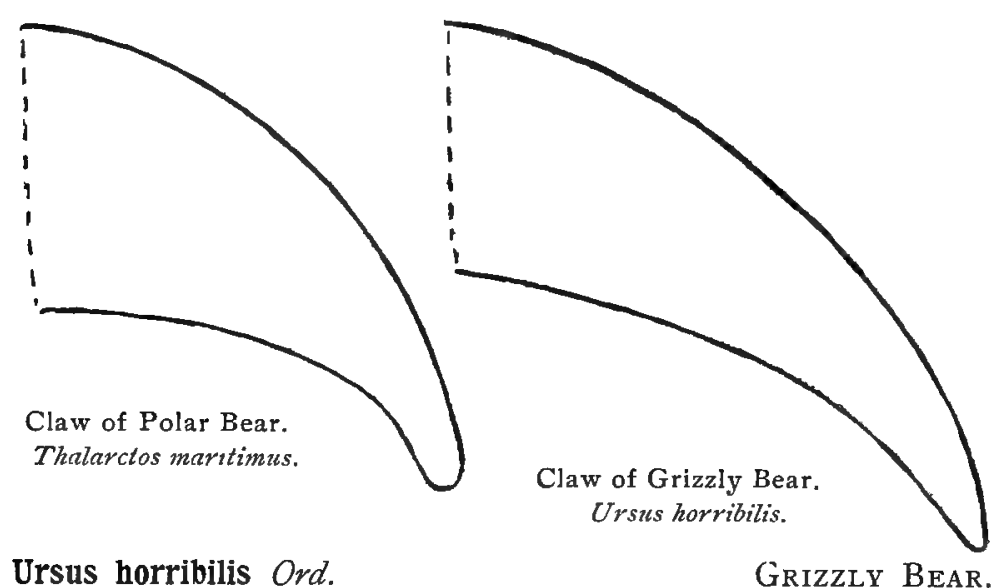

The Loucheux look upon the grizzly with dread and often fire repeatedly at the lifeless carcass, as experience has shown them that the grizzly sometimes recovers from the shock and attacks the unwary hunter. After killing one of this species, while traversing the delta of the Mackenzie, I noticed that our Loucheux canoemen seemed to have a much greater respect for me. ${ }^{1}$ This specimen weighed about seven hundred pounds and its specific gravity was such that it required considerable effort to raise the carcass to the surface after dragging it across the river.

Handsome silver-tipped robes are brought to the trader at McPherson. Another variety, according to Mr. Joseph Hodgson, "varies in color from reddish brown to yellowish white; this is not the Barren Ground bear (U. richardsoni Reid), the skins of which are brought to us by the natives living east of the Mackenzie Delta."

I saw at least a hundred skins from the coast between Bathurst Inlet and Cape Tchaplin, Siberia, which exhibited every

1 See p. I40, ante. 
variety of coloration by the admixture of black, white, and brown. The grizzly bear is not decreasing in numbers in the northern ranges of the Rocky Mountains. The true grizzly is in this region found only along its western border.

I did not hear of their being caught in traps. The natives of the interior kill them with muzzle-loading smooth-bores. The flesh is not eaten. The skin is sold for about the same price as is that of the black bear.

One specimen, obtained in the Mackenzie Delta.

Lepus timidus Linn.

Arctic Hare.

Ka-cho, D. R.

On the 26th of March, 1894 , an arctic hare was killed near our camps, situated a hundred and fifty miles northeast of Rae, and brought to me as a specimen rare for that region. It was conspicuously larger and heavier than the northern hare, L. americanus, with softer, thicker pelage. The fur of this specimen (No. II,034), which was taken in March, is pure white throughout, except the tips of the ears which are deep black in color for the distance of $1 / 2$ inch. There is a much greater proportion of under fur to outer hair than in L. americanus, and it is white to the base. ${ }^{1}$ The ears equal the head in length-4 $1 / 4$ inches. The hind feet are $6 / 5$ inches in length and densely furred over the entire surface to the depth of $I$ inch. The nails of the middle toes are $3 / 4$ of an inch, in length, all are horn-colored along the convex median line, reddish brown on the basal half and white on remainder of sides. They are grooved beneath.

The Indians assured me that the arctic hare was common in the Barren Ground, yet neither I nor any other member of our party discovered a trace of them during twenty-two days which we spent in that region. Richardson gave as their habitat the clumps of spruce-fir along the border of the Barren Ground. They occur along the upper Yukon, yet, strange to say, are quite unknown about the mouth of the Mackenzie, and along the timber line west of it. They were rarely seen south of the Churchill a hundred years ago, but were very common north of that river. ${ }^{2}$ Their footprints on the snow of the frozen sea

1 "Fur resembles swan's down rather than hair." Lyon, Fournal, p.69.

* Hearne, Fourney, p. $3^{82 .}$ 
have been seen twenty miles north of Grinnell Land in latitude $83^{\circ}$ IO $^{\prime}$ N. ${ }^{1}$

One specimen; Rae, March 20th, I894.

Lepus americanus Erx.

VARYing Hare.

Wă-pus, C.

Ka, D. R.

$\mathrm{Ke}, \mathrm{L}$.

$\mathrm{Ka}, \mathrm{S}$.

The northern hare makes a complete change of pelage in winter throughout this region. Specimens from the Saskatchewan do not differ from others taken at Rae. As it is a well known species, no detailed description need be given. The rabbit, as it is called, has been of inestimable value to the inhabitants of the north, both white and red. When the fishery fails, or the "deer" migrate by a different route, the only resource is the rabbit snare to save them from starvation. The northern hare is subject to periodic epidemics which kill immense numbers of them. They seemed equally common during the winters of $1892-3$ and 1893-4; the natives at different posts gave different dates as the year of greatest abundance, so that I am inclined to think that they do not increase and decrease simultaneously over the whole region, but that it is by periods of seven years each all seemed agreed. ${ }^{2}$

I was in the bush almost every day, yet in summer I saw very few hares. At the time of their autumnal change of color, they are very conspicuous for a few days before the snow appears, though the transformation is very quickly accomplished. ${ }^{3}$

They are caught in snares made from "jackfish twine." The noose is set across their run ways, the upper end of the twine being attached to a springe or a pole used as a weight which is balanced over a convenient limb for a fulcrum and held down by passing the twine under a prostrate young pine which also serves to keep the animal in the path. As soon as the noose pulls enough to turn down the stick which is tied in the twine it is tripped and the hare is caught either by the neck or hind foot, and lifted four or five feet in the air.

The skin of the northern hare, while it has no commercial

1 Fielden, Zoologrst, Vol. I, 3rd Series, p. 353.

2 They are said, by Richardson, to die after a wet summer. Parry's Second Voyage, p. 326.

3 See J. A. Allen, On the Seasonal Change of Color in the Varying Hare. Bull. Am. Museum Nat. Hist., Vol. VI, p. 107-28. 
value, is of great service to the natives. They cut the skins into strips and weave them into robes which are said to be the warmest made. The Slaveys, Trout Lake, and other Indians, south and west of the reindeer country, weave capotes of the skins. I noticed that nearly every man, woman, and child at Hay River had such a garment. The traders buy hares for the flesh at six cents each.

They occur throughout the wooded portion of this region and among the willow-fringed islands in the delta of the Mackenzie beyond the limit of forest growth.

Twelve specimens were secured; eight at Grand Rapids, two at Chippewyan in summer pelage, and two at Rae.

Sciurus hudsonius Pallas.

RED SQUiRRel.

Än-ìk-wai-chäs, C. Tlo, D. R. Clo, S. Tlŭk, L.

Common throughout the wooded country, seen at all seasons. Their loud scolding chatter often proved annoying when I was in pursuit of wary birds.

Twelve specimens were secured at Grand Rapids.

Sciuropterus volucella sabrinus (Shaw). Flying Souirrel.

Tswäg u-nǐk-wai-chäs. C.

A single specimen was obtained at Grand Rapids, where they are very rare.

Tamias asiaticus (Gmelin) Allen.

Chipmunk.

Chäs-se-cŏw-e-pı̌s-kus, C.

Two specimens were secured at Grand Rapids, where they are not uncommon.

Spermophilus empetra

Ground SQUirReL.

Ground squirrels or "siffleux" as they are known to the Company's people, are a characteristic feature of the barren portions of Arctic America. In summer the traveler is greeted from every dry knoll and hilltop by their pert whistle. The skins are used for clothing by the natives.

Three specimens were secured at Herschel Island. 


\section{Peromyscus leucopus articus}

White-Footed Mouse.

A single specimen from Rae.

Another woolly mouse from the same locality belongs to the genus Microtus. The collection also contains a common house mouse (Mus musculus) from Grand Rapids, where they were abundant notwithstanding the isolated situation of the post and the apparently extremely unfavorable habitat.

Fiber zibethicus (Linn.).

Muskrat.

Wŭh-chŭsk, C. Dzon , D. R. Dzuñ , L. Te-kă-ĭ, S.

The muskrat does not differ materially in color as we advance northward, though there are localities where melanistic forms are said to occur in considerable numbers, as along the Saskatchewan River below Prince Albert. Nearly every post receives an occasional albino, for which a "present" is always expected.

The muskrat finds in the North an environment perfectly adapted to its aquatic habits, during a portion of the year at least. They do not build winter houses as extensively as those farther south, but usually burrow in the banks of streams and ponds; they prefer the streams to the swamps, and are especially abundant in the deltas of the large rivers, where they may be seen by day, but at night they fairly swarm in the smaller channels. In traveling there by canoe one notices the blackish muzzles moving about, followed by long, ever-widening ripples; every few moments there is a startling plunge at the bow of the canoe. The Indians try to entice the rats toward them by a peculiar teasing, "kissing" sound.

They have little commercial value, yet, owing to their numbers they are the main dependence of the Crees on some of the Saskatchewan reserves. Over twenty thousand skins are sometimes received during one winter at a single station. In the month of February, I893, the Cedar Lake Indians were killing them at the rate of six hundred a day. A whole family would engage in the slaughter, stationing the wife and children, armed with spears, at the air-holes; the hunter would frighten the rats out of the house to be killed as soon as they rose to breathe. Later in the spring, hundreds were shot as they swam about in 
the water on the overflowed ice. A métis-old Antoine Chartier-at Grand Rapids told me that he had secured sixty in a day in this way and that others had killed over a hundred. Those which are trapped of course furnish better skins than those which are mutilated by spears or shot.

They are worth from two to four cents apiece in the country. In the far North the traders discourage their capture as the cost of transportation exceeds the profits when the market price is low.

Muskrats are a common article of food among the natives, and when fat are not to be despised.

They are found as far north as the mouth of the Mackenzie. They have been seen, in the mountains west of McPherson, 3,000 feet above the sea level.

Four specimens; one from Grand Rapids, two from Chippewyan, and an albino from Simpson.

Castor canadensis Kuhl.

BEAVER.

$$
\text { U-mĭsk, C. Tsă, D. R. Tse, L. Tsă, S. }
$$

During the six months which I spent at Grand Rapids, only one beaverskin was brought to the post, and that came trom a distance. No trace of them is to be found within several miles of the fort. Farther up the river a small annual catch is made but the industrious and populous communities, which in the past so materially modified the appearance of the country, are gone. The broken, grass-grown earthworks of the beaver meadows are sad reminders of our accountability for the destruction of these intelligent animals.

Whole families of albino beavers have been seen in the Peace River Region (Mackinlay).

Mr. James Hislop trapped a beaver near Athabasca Landing so large that it attracted his attention though he yearly handled hundreds of skins. Unfortunately he took but one measurement, noting that the tail was 7 inches in width; beavers weighing 40 to 50 pounds measure 4 or 5 inches across the the tail. The heaviest recorded weight is 60 pounds. ${ }^{1}$

Beaver tails are sometimes used by the white trappers as bait for their fox traps.

' Morgan, L. H., The American Beaver and his Works, p. 23. 
Fifteen years ago the York boats, which carried the Company's freight on Peace River, depended upon the beavers killed en route for provision, now they are so rare that only occasional beavertails reach the posts as presents from the Indians. The beaverskin was originally the standard in bartering with the Indians. ${ }^{1}$

Five to eight MB are paid for a beaverskin at the present time. The beaver occurs throughout the wooded portions of this region, excepting those localities where it has been recently exterminated. They are not known to occur in the Barren Ground.

2 See p. 59, ante. 


\section{B I R D S}

O WING to the difficulties of northern transportation, goose, swan, and other bulky skins were not saved. All the specimens here enumerated were made up by the writer, except eight skins which are the gift of Mrs. W. C. King, of Cedar Lake, and one specimen from Rae. With the exception of the Crow Nest Pass collection, all were dried before being packed, and reached Iowa City in excellent condition. A number of crania, sterna, and internal organs were preserved.

The Grand Rapids specimens were obtained between August 30th, I 892, and February 20th, I893. Together with those collected in $189^{1}$ the list of birds to be found at that post is believed to be fairly complete. Cedar Lake is certainly a much better station for an ornithologist.

Macleod is on the border of the Rocky Mountain region and, while it is not a desirable location, would be a good starting point from which to enter the Crow Nest Pass. The prairie region, which contains many lakes, between Winnipeg and Macleod is the great breeding ground of the smaller water birds as well as of Canada geese and many of the ducks. North of this, toward the North Saskatchewan, a scattered growth of poplars, alders, and other small deciduous trees, offers a barrier to the further northward movement of many of the land birds. Beyond the Saskatchewan the country east of the Mackenzie system is nearly uniform in its nature, consisting of low Archæan hills scantily covered with coniferous forests, interspersed with muskegs and lakes.

The Chippewyan collection is a fairly representative one for the month, May I5-June I5. I stationed myself on the most conspicuous island in the midst of the large delta-plain at the western end of Lake Athabasca, where I could devote my

1 See report by Professor C. C. Nutting, in Vol. II, No. 3, of the Nat. Hist. Bull. of the State Univ. of Iowa. 
attention to both land and water birds. Such small birds as crossed the lake might be expected to halt at that point which was the first high ground on the north shore. Any species recorded from that place might reasonably be expected to be found as far northward as the Great Slave Lake.

Near Smith a well known breeding place of the white pelican is to be found in a picturesque spot among the rapids of the Slave River.

The Great Slave Lake presents the most formidable barrier to the passage of the smaller land birds that is to be found in the whole county. North of the lake the observer is impressed with the change in plant and animal life. It was my privilege to travel along a considerable portion of the north and south shores both in summer and in winter. There are very few species of birds to be found north of the lake in winter; even in summer, birds are not abundant around the lake.

The delta of the Mackenzie is by far the best locality in this entire territory for the collecting naturalist. Game birds are abundant so that the food problem, which becomes an important one in that inaccessible region, is easily solved. Many western species occur there. I very much regretted the necessity which compelled me to pass specimens which were new to me, and I was disappointed in the hope of finding some of them at Herschel Island. Only water birds or a few species peculiar to barrens are to be found at that station. In July and August the cacawees may be seen in enormous flocks along that coast; the brown crane breeds near the mouth of the Mackenzie; loons are common all along the coast. Gulls and jaegars are not abundant.

2. Colymbus holboellii (Reinh.). Holbcell's GREbe. One specimen; Rae, August 22. Not uncommon.

\section{Colymbus nigricollis californicus (Heerm.).}

American Eared Grebe.

One specimen; Rae, August 22.

7. Urinator imber (Gunn.).

LOON.

One specimen, of; Prospect Lake, Rae, July 29. Common about the lakes which contain fish throughout this entire region. 
The natives imitate its strident note, but are more successful in bringing it within gunshot by flashing some white object in the sunlight. I have seen the Indians cook this bird, but one mouthful was too much for them.

I I. Urinator lumme (Gunn.).

RED-THROATED LOON.

One specimen; King Point, July 5. Abundant along that portion of the Arctic coast which I passed in my canoe-between the Mackenzie and Herschel Island. The red-throated loon is not as wary as the preceding; its flesh is tolerably palatable.

\section{Stercorarius parasiticus (Linn.). Parasitic Jaeger.}

One specimen; an egg from the coast, near the mouth of the Mackenzie, June 27. The nest was simply a level bit of dry moss on the tundra, a few yards from the water's edge, and contained but one egg. The parent bird, which tried to drive me away from the locality, was also collected, but the skin was unfortunately lost in traveling to Herschel Island.

\section{Stercorarius longicaudus Vieill. LONG-TAILEd JAEger.}

This species is said to pass Rae in considerable numbers during the spring migratory season.

A specimen, which had been killed during the spring of 1893 , was obtained from a young Indian at the station. He had mounted it fairly well upon a board and had inserted shoe buttons for eyes.

\section{Larus glaucus Brïn.}

Glaucus Gull.

One specimen, 9 ; Herschel Island, August 4.

\section{A. Larus argentatus smithsonianus Coues.}

American Herring Gull. Two specimens; Rae, July $2 \mathrm{I}$; one $\hat{\delta}$, one $q$.

\section{Larus delawarensis Ord. \\ Ring-BILled GuLl. Ki-äck, C.}

Eight specimens; Grand Rapids, five juv; Chippewyan, two $\hat{b}$, one $q$; Rae, one juv. Commonest of the gulls, not abundant 
at Chippewyan, said to breed on a small island twenty miles east of the post. I found these gulls abundant and very fat at Big Slavey Point, May I2, the snow still deep.

70. Sterna hirundo Linn.

Common Tern.

Two specimens, f;; Grand Rapids, September I2. Abundant about Lake Winnipeg and Cedar Lake, less common northward.

86c. Fulmar glacialis rodgersii (Cass.). ROdGERs's Fulmar.

One specimen; at sea, latitude $7 \mathrm{I}^{\circ} 5 \mathrm{O}^{\prime} \mathrm{N}$., northwest of Herald Island, September 26.

96. Puffinis tenuirostris $($ Temm.).

Slender-billed Shearwater.

One specimen, which alighted upon the deck of our vessel, while crossing Behring Sea. This bird seemed to be uninjured, yet could or would not rise to escape before I caught it with my hands.

\section{Pelecanus erythrorhynchos Gmel.}

American White Pelican.

Ten specimens; Mountain Rapids, Slave River, July 3; three young birds at different stages of development were selected from the many score that were on an island at the head of the rapids. Seven eggs have survived the vicissitudes of northern travel. White pelicans are common at Grand Rapids, and at a few other points about Lake Winnipeg. ${ }^{1}$ The Mountain Portage is the most northerly breeding place of which I have any knowledge. They are rarely seen as far north as the Great Slave Lake.

129. Merganser americanus (Cass.). American Merganser.

Four specimens, one $\&$, three juv.; Rae, August 22. Not uncommon, breeding.

132. Anas boschas Linn. Mallard. "Stock Duck." Aĭ-ĭn-i-sip, C.

Three specimens; one from Cedar Lake, s, two taken at Chippewyan, May 20, $\delta$. Abundant during the migratory season at

1 See p. 1 , ante. 
such feeding grounds as the deltas of the Saskatchewan (Cedar Lake), Athabasca, Slave, and Mackenzie Rivers. Rare along the Northern Arm of the Great Slave Lake. This species is systematically hunted in the fall and "hung" for winter use at many of the Company's posts.

\section{Anas penelope Linn.}

WidgEON.

Two specimens; one from Grand Rapids, September I; one $q$, Rae, August 22.

\section{Anas americana Gmel.}

BAIDPATE.

Two specimens; Cedar Lake; Chippewyan, \&, May 23. Only one seen at the latter station during the month spent there.

\section{I39. Anas carolinensis Gmel. Green-winged Teal.}

Two specimens; fo and +, Chippewyan, May 20-30.

\section{Spatula clypeata (Linn.).}

SHOVELleR.

One specimen, 占; Chippewyan, June 7. Not uncommon, breeding.

143. Dafila acuta (Linn.).

Pintail.

Two specimens; Chippewyan, ô, May 18-June 3. Perhaps second to the mallard in value for food; not so wary. Common at Chippewyan, breeding.

I49. Aythya affinis (Eyt.).

Lesser Scaup Duck.

Six specimens; two from Chippewyan, June 5 ; five, one $q$, three juv., Rae, August I. Common among the islands of the north shore of the Great Slave Lake, where they are "little black ducks," breeding. Rare at Chippewyan.

I 50. Athya collaris (Donov.).

RING-NeCKed Duck.

One specimen; Chippewyan, May 22. No others seen there.

I 55. Histrionicus histrionicus (Linn.) HarLeQUiN Duck.

One specimen, 9 ; Rae, July 27. 
I66. Odemia perspicillata (Linn.).

SURF Scoter.

One specimen, 9 ; Rae, July 27.

167. Erismatura rubida (Wils.).

RudDy Dưck.

Two specimens; Cedar Lake.

I68. Nomonyx domincus (Linn.).

MASKed DUCK.

One specimen; Cedar Lake.

172. Branta canadensis (Linn.).

Canada Goose.

I72A. Branta canadensis hutchinsii (Sre. \& Rich.).

Kă, D. R. Hutchins's Goose.

The "gray goose" is common throughout this region, at least during the migratory season, and furnishes food in the spring for many natives. The arrival of the first goose in the spring is a matter of record at every post. The Indian bringing the first specimen of the season to the station is rewarded with a handsome "present," the engaged servant who first kills a goose also receives a gratuity amounting to several skins in value. The average date of arrival of the geese at Simpson for a period of thirteen years is April 28th. The record is as follows.

\begin{tabular}{|c|c|c|c|c|c|c|c|c|c|c|c|c|c|}
\hline I88I, & & & • & . & & April $3^{\circ}$ & I 888, & & . & & & & May 3 \\
\hline I882, & & • & - & . & . & April 29 & I889, . & ${ }^{\circ}$ & . & & • & & April 23 \\
\hline ×883, & & & • & • & . & April 26 & I89o, & & . & & ${ }^{\circ}$ & - & April $3^{\circ}$ \\
\hline I 884 , & & & - & . & & April 27 & I891, . & & . & & - & & $\longrightarrow$ \\
\hline 1885, & 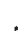 & $\theta^{\prime}$ & . & . & & April 25 & 1892, & & . & . & - & - & April 24 \\
\hline I886, & . & • & . & . & & May 8 & $1893,$. & 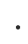 & & . & . & • & May 8 \\
\hline โ887, & . & & . & . & & April 26 & I 894. & & . & . & . & . & May 4 \\
\hline
\end{tabular}

Geese are purchased at the rate of two for I MB. Large numbers are salted for use at the stations. The snow geese are killed by thousands at Chippewyan. A much smaller number than formerly is obtained at Big Island, a famous "goose ground," and they are surely passing away.

223. Phalaropus lobatus (Linn.). Northern Phalarope.

One specimen, $f$; Herschel Island, July 14. Common on the tundra.

233. Micropalma himantopus (Bonap.). Stilt Sandpiper.

Two specimens, fo; Chippewyan, June 6-12. Passing north- 
ward in considerable numbers during the month of June. Called by a Cree visitor-mŭc-e-ow se-ge-měs-a (big mosquito).

\section{Tringa maritima Briinn.}

Purple Sandpiper.

Ten specimens; Chippewyan, two fo, two o, two ?; May 30June 8; Herschel Island, three f, one of; July I3-August I4. Abundant at both stations.

\section{I. Tringa bairdii (Coues).}

BAIRD'S SANDPIPER.

Three specimens, one ô, two ơ; Chippewyan, May 25-June I. Common.

246. Ereunetes pusillus (Linn.). Semipalmated Sandpiper.

Eleven specimens; Chippewyan, four t, two + , two ?; June 2-I2; Herschel Island, one t, two o; June I4-August 2.

248. Calidris arenaria (Linn.).

SANDERLing.

One specimen, 9 ; Chippewyan, June 7.

262. Tryngites subruficollis (Vieill.).

BUfF-breasted Sandpiper.

One specimen, Herschel Island, August I 3 .

263. Actitis macularia (Linn.).

Spotted Sandpiper.

Eight specimens; Chippewyan, three o; May 23-June 9. Four eggs and a nest were collected, the nest was a depression in the sand, scantily lined with grass. This is the commonest shore bird of the north, it is to be found along along all shelving beaches.

270. Charadrius squatarola (Linn.). Black-Bellied Plover.

One specimen, ô; Chippewyan, June 8. Not common.

272. Charadrius dominicus Miill. American Golden Plover.

Two specimens; Chippewyan, one $\hat{o}$; June I; Herschel Island, August I3. A few flocks halt at Athabasca to feed in the deltas. Not uncommon at Herschel Island where they first arrived from the northward on the $13^{\text {th }}$ of August. 


\section{Aegialitis semipalmata Bonap. Semipalmated Plover.}

Three specimens, one $\delta$, one 9 , one ?; Chippewyan, June 2I2. Not common.

\section{Dendragapus canadensis (Linn.). Canada Grouse. Měs-tı̌k-o-pĕn-e-o, C.}

Ten specimens; Grand Rapids, two ô, seven juv.; September 5-December 3; Chippewyan, one \%; May 29. Common at Grand Rapids.

300A. Bonasa umbellus togata (Linn.).

Pa-pas-ku, C. Canadian Ruffed Grouse.

Eight specimens; Grand Rapids, five f, one \%, two -; September 10-December 29; Chippewyan, May I8. During our boat voyage down the Athabasca, we heard the drumming of these birds at all hours of the night.

3Оов. Bonasa umbellus umbelloides (Dougl.) Gray.

RufFed Grouse.

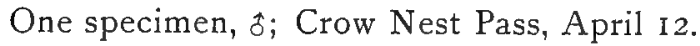

301. Lagopus lagopus (Linn.).

Willow Ptarmigan. Wa-pĕn-e-o, C.

Twenty-two specimens; fifteen from Grand Rapids, two $\hat{b}$, nine $q$, four - ; November I2-February 8; seven from Rae, four 8 , three 9 ; October 2-May 7. The ptarmigan made their appearance at Grand Rapids on the 12 th of November in 1892 . The Indians brought the first specimen to me, but it was so torn by No. I shot and the beautiful plumage so covered with blood that it was almost impossible to make a good skin of it.

The ptarmigan were not abundant that season. I never secured more than two or three during a day's hunt that could be saved as specimens so easily did their immaculate plumage become stained when even the smallest shot was used. They frequented the sandy dikes of the lake shore where they fed upon the willow buds. They were not easily distinguishable at a little distance from the balls of snow which were common in the willow tops. In flight they keep so near the surface of the snow that wing shots are rather difficult unless they pass before a dark background of pines. 
The specimens from Rae form a series showing the complete transition from the summer-brown to the winter-white plumage. A male bird which was taken in a snare May 7 th, has a chestnut brown head and body as yet white. ${ }^{1}$

302. Lagopus rupestris (Gmel.).

Rock Ptarmigan.

An Indian in our party killed a rock ptarmigan in the Barren Ground over one hundred miles from the edge of the woods, during the musk-ox trip in April. There was no thaw in that region until over a month later.

308. Pediocaetes phasianellus (Linn.). Sharp-tailed Grouse. Aq-sco-pĕn-e-o, C.

Fourteen specimens; eleven from Grand Rapids, one $\$$, three o, seven juv.; August 30-November 2I; Rae, two $\hat{\delta}$, one $q$; October 4-7. Abundant at the first station, rather common at Rae during the autumnal migration. They are highly esteemed for their flesh by the natives, and are certainly superior to either the ptarmigan or the white-fleshed ruffed grouse.

\section{I. Circus hudsonius (Linn.). Marsh Hawk. \\ Pi-pun-e-su, C.}

Three specimens; Swampy Island, Lake Winnipeg, 9 , August 28; Chippewyan, ㅇ, June I; Rae, juv., August 22.

332. Accipiter velox (Wils.). Sharp-Shinned Hawk.

Four specimens; three from Grand Rapids, + , September 6I9; Rae, o, August I7.

\section{Accipiter atricapillus (Wils.). American Goshawr. Con-o-chikk-in-o-chi-we-su, C.}

Nine specimens: Grand Rapids, two juv., September I5; seven from Rae, juv., \&, ?, July 26-October 5. The commonest representative of this order about Rae. ${ }^{2}$

337. Buteo borealis (Gmel.).

ReD-TAILED HaWk.

One specimen, 古; Grand Rapids, September I9.

1 See page 86 , ante.

- See page 86, ante. 
348. Archibuteo lagopus sancti-johannis (Gmel.).

American Rough-Legged Hawk.

One specimen, of; Herschel Island, August 4.

352. Haliaeëtus leucocephalus (Linn.).

Bald EAgle.

$$
\text { Mi-ğ̌-su, C. }
$$

One specimen, juv.; Grand Rapids, October I4. Not uncommon throughout the North. I saw a bald eagle on November 3d, at Rae, which seemed to be following the caribou in their migration.

356. Falco peregrinus anatum (Bonap.).

Duck Hawk.

One specimen, o; Herschel Island, August I6.

357. Falco columbarius Linn.

Pigeon Hawk.

Two specimens, 占; Rae, May 5.

360. Falco sparverius Linn.

American Sparrow Hawk. Pĕ-pi-ge-sis, C.

One specimen, juv.; Grand Rapids, September 5. Common.

364. Pandion haliaeëtus carolinensis ( $G$ mel.). American Osprey

One specimen, 8 ; Rae, July 26. Not uncommon about the Great Slave Lake.

366. Asio wilsonianus (Less.). American Long-Eared OwL.

One specimen, 9; Crow Nest Pass, April I 5.

370. Scotiaptex cinereum (Gmel.). Great Gray OwL.

One specimen, o; Rae, May 4.

375. Bubo virginianus (Gmel.). Great Horned Owl.

$$
\text { Co-co-tco, C. }
$$

Two specimens; Grand Rapids, 9 , February 8; and a halfgrown specimen from Salt River, June 28.

377A. Surnia ulula caparoch (Miill.). American Hawk Owl. Tci-pom-o-tciz, C.

Five specimens; four in the Grand Rapids collection, one $\delta$, one ?, two ?; December 6-January I. One from Rae, $\delta$; October 2 . 
390. Ceryle alcyon (Limn.).

Kis-ki-mĭn-e-suq, C.

Belted Kingfisher.

Three specimens; Grand Rapids, one \&, two ?; September I3-I9. Everywhere common.

393. Dryobates villosus (Linn.).

HAIRy WoODPECKer.

Four specimens, one 8 , three $q$; Grand Rapids, November 5-February 16. Common.

393A. Dryobates villosus leucomelas (Bodd.).

Northern Hairy Woodpecker.

Two specimens, 今; Grand Rapids, November 16.

394. Dryobates pubescens (Linn.). Downy WoodPecker. Pa-pa-tcez, C.

Seven specimens, three $\delta$, three \%, one ?; Grand Rapids, September 7-November 29. Common.

400. Picoides arcticus (Swains.).

Arctic Three-toed Woodpecker.

One specimen, §, Grand Rapids, November I; one f, Chippewyan, June 2 .

40IA. Picoides americanus alascensis (Nels.).

Alaskan Three-toed Woodpecker.

Two specimens, ô; Grand Rapids, September Io-October 3 I. Not common.

402. Sphyraphicus varius (Linn.).

Yellow-Bellied Sapsucker.

One specimen, received from Cedar Lake. I should suppose them to be rare in that region, as I saw none myself, though I took some pains to collect a representative series of the Picidæ.

405. Ceophloerus pileatus (Linn.). Pileated Woodpecker.

One specimen, 8; Grand Rapids, Oct. 26. The first killed about that post for several years. Later in the season, I heard the loud note of another, but failed to approach it successfully. I killed three while in the Puget Sound country and found them exceedingly wary. 
412. Colaptes auratus (Linn.).

U-ni-kwa-ne-o, C.

FLICKER.

Four specimens; three from Grand Rapids, two $\delta$, one ?, Sept. 2I-Dec. 30; one 8, from Chippewyan, May 22. Everywhere common.

4I3. Colaptes cafer (Gmel.). Red-Shafted Flicker.

One specimen, $\delta$; Crow Nest Pass, April II. One seen at Chippewyan, May 2I.

420. Chordeiles virginianus ( $G m e l$.).

NIGHT-HAWK.

One specimen, 古; Chippewyan, June I2. Abundant at Grand Rapids, not uncommon at Chippewyan.

456. Sayornis phoebe (Lath.).

Phøвв.

One specimen, 古; Chippewyan, May 20. I found this species abundant at the time of my arrival, May I8.

467. Empidonax minimus Baird. Least Flycatcher.

Two specimens, of; Chippewyan, May 26-30. Common; a shy but noisy little wretch, ever ready to raise an alarming outcry when its own skin was quite safe.

469. Empidonax wrightii Baird. Wright's Flycatcher.

One specimen, ô; Crow Nest Pass, April I I.

474A. Otocoris alpestris leucoloema (Coues).

Pallid Horned Lark.

Six specimens; one of, taken at Grand Rapids, September I3; five at Chippewyan, four $\delta$, one $q$, May 20-25. Not uncommon at both stations.

477. Cyanocitta cristata (Linn.).

Blue Jay

Two specimens, of; Grand Rapids, Nov. 2. Very rare at that station.

484. Perisoreus canadensis (Linn.). Cinada Jay. Kwi-kwé-su, C.

Thirty specimens; Grand Rapids, eleven $\hat{\jmath}$, ten $\$$, six ?, Sept. 5-Feb. I7; Chippewyan, two juv., May I9; Rae, one f. Oct. I3- 
19. Everywhere common, a well-known camp prowler. Whiskey jacks are often caught by the natives in snares and tortured in various ways on account of their supposed evil influence on sailing winds. ${ }^{1}$

486A. Corvus corax principalis Ridgre. Northern Raven. Ka-ka-gé-o, C.

Six specimens; Grand Rapids, two, Sept. 2I-Nov. 26; Fort Smith, one f, June 28; Rae, one $f$, one $q$, one juv.?, August 3-I8. Not uncommon throughout this region; a winter resident at the fishery refuse heaps at Grand Rapids, but I have not seen it in summer at that station; a rare winter resident at Rae. We saw several ravens perched on the "mud cliffs" between the mouth of the Mackenzie and Herschel Island. The raven is called "crow" in the North.

488. Corvus americanus Aud

American Crow. A-ha-cu, C.

One specimen, f; Grand Rapids, Sept. I 3. Common. Richardson places the northern limit of range of the "barking crow" at "The Rapids" or Providence. ${ }^{2}$ Mr. Hodgson, of the Hudson's Bay Company, who traveled up and down the Mackenzie each summer for many years, assured me that he had never seen the crow below the "Head of the Line." Mr. McConnell states ${ }^{3}$ that the barking crow made its appearance at Simpson on the 20th of May, in 1888.

49I. Nucifraga columbiana (Wils.). Clarke's Nutcracker.

Three specimens, 古; Crow Nest Pass, March 28-April I2. Common.

495. Molothrus ater (Bodd.).

COWBIRD.

Five specimens, of, one o, three juv.; Grand Rapids, Sept. 13Oct. 27. Abundant.

497. Xanthocephalus xanthocephalus (Bonap.).

One seen at Chippewyan.

1 See p. 36, ante.

- Arctic Searching Expedition, p. I02.

${ }^{3}$ Ann. Rep. Geo. Sur. of Canada, Vol. IV, p. 86D. 
509. Scoleocophagus carolinus (Mïll.). Rustr Blackbird.

Two specimens, o; Chippewyan. May 19-23. Abundant.

510. Scoleocophagus cyanocephalus (Wagl.).

Chu-tcŭk-e-nu, C. BREWer's BLACKBIRD,

Two specimens; one from Grand Rapids, Sept. 7; one from Chippewyan, 8, May 23. Abundant at the latter station. Grand Rapids, sex?, Sept. 6.

515. Pinicola enucleator (Linn.).

Pine Grosbeak.

Four specimens, two 8 , two o; Grand Rapids, Oct. I4-Nov. I 7.

517. Carpodacus purpureus ( $\mathrm{Gmel}$.).

PURPLe Finch.

Two specimens, f; Chippewyan, \&, June 5. Only two were seen at that station.

522. Loxia leucoptera Gmel. White-Winged Crossbill.

One specimen, ; Grand Rapids, Nov. 3. A rare visitor.

\section{Leucosticte tephrocotis Swains.}

Gray-Crowned Leucosticte.

Seven specimens, three of, four o; Crow Nest Pass, April I4. Abundant.

528. Acanthis linaria (Linn.).

REDPOLL.

Fifty-two specimens; Grand Rapids, nine $\delta$, seventeen $q$, five ?, Oct. 27-Dec. 29; Crow Nest Pass, one $\hat{\delta}$, three ?, April I5; Rae, one $\delta$, four + , seven ?, Oct. 7-I 2; Herschel Island, one $q$, together with a nest and three eggs, July i6. Very abundant at every post at which I collected.

534. Plectrophenax nivalis ( $\operatorname{Linn}$.).

SNowflake.

Forty-three specimens; Grand Rapids, three 8 , two ?, Nov. I-Dec. I 5; Rae, eleven $\delta$, twenty o t, two ?, Oct. 5-13; Herschel Island, five $\hat{8}$, July 16-18. Abundant in the winter at the first station; killed by the natives about the buildings at Rae for food during the fall migration. Common at Herschel Island throughout the summer. I saw a large number in the Winnipeg markets in March. 
- 536. Calcarius lapponicus (Linn.).

LAPLAND LONGSPUR.

Thirty-six specimens; Chippewyan, one $q$, May 24; Herschel Island, twelve $\$$, fifteen o, nine?, July I3-Aug. I 3. Very abundant at Herschel Island. Only one seen at Chippewyan.

\section{B. Ammodramus sandwichensis alaudinus (Bonap.).}

Western Savanna Sparrow.

Five specimens; three $\delta$, one $q$, one ?, Herschel Island, July I6-August I8.

554A. Zonotrichia intermedia Ridgze. Intermediate Sparrow.

One specimen, $\delta$; Rae, July 2 I.

558. Zonotrichia albicollis ( $G m e l$. .). White-throated Sparrow.

One specimen, $\delta$; Chippewyan, May 22. Common at Grand Rapids. Their long-drawn, out-of-breath note often heard at Chippewyan.

559. Spizella monticola (Gmel.).

Tree Sparrow.

Seven specimens; Grand Rapids, two f, Oct. I8; Rae, one \&, Oct. II, one +, July 2I; Crow Nest Pass, April II-I 5 .

559A. Spizella monticola ochracea Brezust.

Western Tree Sparrow.

Two specimens, ô; Chippewyan, May 23-June 9.

560. Spizella socialis (Wils.). Chipping Sparrow.

Three specimens; one $f$, one $q$, one ?, Chippewyan, Oct. II. Abundant.

560 A. Spizella socialis arizonae Coues

Western Chipping Sparrow.

One specimen; Chippewyan, May zo.

56I. Spizella pallida (Szains.). Clay-colored Sparrow.

Two specimens; Rae, one juv.

567. Junco hyemalis (Linn.).

Slate-colored Junco.

Twelve specimens; Grand Rapids, one ?, Nov. II; Chippewyan, May I9, one $\delta$. Abundant at both stations, breeding at 
the latter one, at least, where I collected a nest containing five eggs; it was in an exposed situation in a recess at the foot of a sloping bank. Crow Nest Pass, one s, three?, April ro-I I.

583. Melospiza lincolni (Aud.).

LinCOLN'S SPARRow.

One specimen, q, Chippewyan, May 28. Rare. Constantly moving, "tipping" like a sandpiper about the roots of swampwillows.

584. Melospiza georgiana (Lath.).

Swamp Sparrow.

Two specimens, f; Chippewyan, June 2.

607. Piranga ludoviciana (Wils.).

Louisiana TANager.

One specimen; Fort Smith; June 28. Rare.

6i4. Tachycineta bicolor (Vieill.). White-Bellied Swallow.

Four specimens, one $\hat{\delta}$, one + , two ?; Chippewyan, May 20. A pair were building in a hollow tree, June $3 \mathrm{~d}$; no eggs at that date.

6Ig. Ampelis cedrorum (Vieill.). CEDAR Waxwing. Co-sa-go-pa-ton-e-chase, C.

Three specimens, two \&, one ?; Grand Rapids, Sept. 8-9.

621. Lanius borealis Vieill. Northern Shrike.

One specimen, o; Crow Nest Pass, April i I. Common.

624. Vireo olivaceous (Linn.). RED-Eyed Vireo.

Two specimens, one $\delta$, one $q$; Chippewyan, June 6 . Common. 626. Vireo philadelphicus (Cass.). Philadelphia Vireo.

One specimen, $\therefore$; Chippewyan, June 5. Only one seen.

636. Mniotilta varia (Linn.). Black and White Warbleer. One specimen, $\delta$; Chippewyan, May 26. Not uncommon.

647. Helminthophila peregrina (Wils.). Tennessee Warbler.

Four specimens, two $\delta$, one $q$, one ?; Chippewyan, May 30June 6 . Abundant. 
650. Dendroica tigrina (Gmel.).

Cape May Warbler.

One specimen; Chippewyan, May 3I. Only one seen. A straggler?

652. Dendroica aestiva (Gmel.).

YeLLOW WARBLER.

Four specimens; three $\delta$, one 9 , Chippewyan, May 24-June 6. The first warbler to make its appearance (May 24), and by the middle of June the commonest species of the order.

655. Dendroica coronata (Linn.).

Myrtle Warbler.

Six specimens; Chippewyan, two ff, two o, one ?, May 24-30; Rae, one o, July 27.

657. Dendroica maculosa (Gmel.). Magnolia Warbler.

One specimen, f; Chippewyan, June 6. A Cree, who saw me making up the skin, admired the beautiful plumage, and remarked, "Täp-ı̌s-kute pi-e-sis o-ki-mow"-probably it is a king among the little birds!

661. Dendroica striata (Forst.). Black Poll Warbler.

Two specimens, one 3, one 9 ; Chippewyan, May 31.

675A. Seiurus noveboracensis notabilis (Ridgw.).

Grinnell's Water Thrush.

Two specimens; Chippewyan, f, May 24-26. Abundant for two weeks and then disappearing--passing northward.

687. Setophaga ruticilla (Linn.). AMERICAN Redstart.

Three specimens, $A$, Chippewyan, June 5. Common, very tame, often coming within a few feet of me.

697. Anthus pensilvanicus (Lath.). American Pipit.

Two specimens; Chippewyan, o, May 20; Herschel Island, \$, July 18. Rare at both stations.

735. Parus atricapillus Linn.

Chickadee.

Twelve specimens; Grand Rapids, Nov. 18-Feb. 8. Common. 
735A. Parus atricapillus septentrionalis (Harris).

LONG-TAILED CHICKADEE.

One specimen, ơ; Chippewyan, May 30.

740. Parus hudsonicus Forst. Hudsonian ChickadeE.

Eight specimens; Grand Rapids, seven, Nov. 9-Feb. 10; Chippewyan, one, 今, May $3 \mathrm{I}$.

749. Regulus calendula (Linn.). Ruby-CROWNEd KInglet.

Two specimens, of; Chippewyan, May 30-June 9. The following spring I heard the loud note of this pigmy songster at Big Slavey Point, north of the Great Slave Lake, on May I3; the ground was still deeply covered with snow. There could be no mistaking the note--"fatal use," "fatal use;" or, "chappie, chappie, jackfish."

761. Merula migratoria (Linn.).

American Robin.

Pa-pes-cha-o, C.

Six specimens; Grand Rapids, one f, one , Sept. 7; Fort Smith, nest and three eggs, June 28. 


\section{F I S H}

Coregonus clupeiformis (Mitch.) Mil.

WhiteFish.

U-tǐk-u-me-kwă, C. Thlu-ĭ, D. R. Thlu-ă, S. Tluk-tŭk-ı̌-, L.

As the game animals disappear the settlements become more and more dependent on the food fishes of which the various species of coregoni are by far the most important. Fortunately the whitefish is abundant, occurring in nearly every stream and lake in the region visited. It is a gregarious fish which may travel long distances in search of food at the different seasons, or in order to reach shallow waters in which to spawn. As a result of these migrations, whole tribes of Indians are sometimes reduced to starvation. The Company's trading stations, though located near the best fisheries, frequently suffer from the partial failure of the fall fishery. The scarcity of fish at Resolution in the fall of 1893 was ascribed to the high easterly winds which prevailed during the season.

This fish appears to supply all the necessary elements for the nourishment of the body, as it is not only the sole article of diet, but is even preferred by many of the voyageurs while engaged in severe labor. I have eaten no other food but whitefish for weeks at a time, and certainly preferred them to dried caribou meat, though they were nearly always prepared by boiling. On this subject, Richardson" says, "Though it is a rich, fat fish, instead of producing satiety it becomes daily more agreeable to the palate; and I know from experience, that though deprived of bread and vegetables, one may live wholly upon this fish for months, or even years, without tiring." "The mode of cooking the attihawmeg is generally by boiling. After the fish is cleaned, and the scales scraped off, it is cut into several pieces, which are put into a thin copper kettle, with water enough to cover them, and placed over a slow fire;

1 Fauna, p. 195. 
as soon as the water is on the point of boiling, the kettle is taken off, shook by a semi-circular motion of the hand backwards and forwards, and replaced on the fire a short time. If the shaking be not attended to exactly at the proper moment, or be unskilfully performed, the fish coagulating too suddenly becomes comparatively dry to the taste, and the soup is poor.' I was told that the reason for this shaking was " to keep it from sticking to the kettle." Usually no attention is paid to the soup which is, as may be imagined, without salt, not very palatable, though we greatly relished it during our starvation trip across the Great Slave Lake in September, 1893.

The stomach is said to be a "favorite morsel with the voyageurs;" it is not "cleaned and boiled with the rest of the fish" by the Dog Ribs, who usually roast it directly upon the coals, while the kettle is boiling; after scraping the ashes from this blackened morsel they appear to relish it very much and frequently give it to the children. Of the two methods of cooking in vogue, roasting is much the better; the fish is opened along the back, cleaned, scraped, a skewer run through to spread it laterally, and then fixed on the end of a stick which may be set in the ground or snow before the fire. It is opened along the back because the thick flesh at the edges of the cut does not curl and cause it to cook unevenly when subjected to heat.

The inhabitants of the country, especially those in charge of the "pret" become expert in judging the condition of whitefish. The "fat fish has a "scooped head," that is, the shoulders are raised and plump with fat; they are, also, deeper posteriorly.

The lake whitefish arrive at Grand Rapids about the Ioth of May, and move out about twenty miles off shore early in July. After that date the four fishing companies, which annually export several thousand pounds of frozen whitefish from Lake Winnepeg, set their nets on the Saskatchewan Grounds. They have freezing stations at Swampy, Reindeer, and Selkirk Islands and at the mouth of the Saskatchewan and Little Saskatchewan Rivers. Several miles of gill nets are maintained, and the catch in 1892 exceeded that of any preceding year.

The most of the Company's posts have been established near fisheries or points where the whitefish come during the spawning season. They are then taken in large numbers and "hung" for consumption during the long winter. 
The harvest time of the Grand Rapids Indians is in October when the fish come into the shoal waters, which extend for several miles southeast of the reserve. Each family buys or begs six balls of twine from which the women soon weave a net, sixteen meshes wide, and twenty-five to thirty fathoms long. This is a stormy season and the coast is fully exposed to the northerly gales which frequently prevent them from visiting the nets for days and sometimes the net, heavily loaded with fish, is carried away and lost, a serious misfortune to the poverty-stricken owner. Ordinarily the net is visited two or three times a day. The fish are hung at the fishery in "sticks" upon staging, to dry and freeze; a stick, an inch in diameter is thrust through the tail and they are hung heads downward in bunches of ten. The flesh becomes firmer by this process which usually tends to improve them, but if warm weather overtakes them while on the stage the characteristic "hung" flavor becomes unbearably rank. Larger fish are reduced to the whitefish standard by hanging fewer of them in each bunch.

The gill nets used in the eddies of the streams are shorter than those of the lake. Scoop nets are used at the Grand Rapids of the Saskatchewan in September and October. They are two to three feet in diameter with a handle twelve feet long. The net is swept down with the current, sometimes, bringing up two or three fish at a haul; again, the fisherman casts for hours without success. It is very fatiguing work, standing in the snow and swinging the heavy net, dripping with ice-cold water. The whitefish taken in the river are much smaller than those from Lake Winnipeg.

What are known as "small whitefish" weigh two to three pounds. I found these in the Saskatchewan, Slave, and Buffalo Rivers, and at Rae. The "large whitefish" were abundant in Lake Winnipeg, at Resolution, Hay River, and Big Island, about the Great Slave Lake and on the Lower Mackenzie and the Peel River. Old Jack Fiddler sent two fish to the post, during my stay, which weighed fifteen and sixteen pounds each. Whitefish have been caught near Grand Rapids which exceeded twenty pounds each in weight. The nets are set under the ice in winter, especially if the fall fishery has been a failure. This is done by cutting holes at intervals through which by means of a long, spliced pole a line is passed by which the net is 
dragged under when the ice becomes five or six feet thick. Considerable labor is required to dig the deep trenches in which to pass the pole under. Sticks are set up in a circle around the ends of the net, which support the blanket of the fisherman when the net is visited; the shelter being placed on the windward side, nothwithstanding this precaution it is bitterly cold work, handling the net, when the hands are raised out of water. Two persons are required to handle a net under the ice, one attends to the net itself and the other, to the line by which it is reset. ${ }^{1}$

The average fall catch made by the Indians at Grand Rapids is about II,000. The largest number secured by one family was 1,000 , the smallest, I 40, the average, only 375 . This was, of course, an insufficient supply, and several families were "starving" before February, that is, either living on hares, owls, martens, and other fur-bearing animals from the traps, or stealing from the log pens in which their more industrious neighbors had cached their fish along the lake shore, to be hauled in by dogs in the winter.

Two specimens, skeletons, Grand Rapids.

\section{Acipenser rubicundus Le Sueur. \\ Ni-me-o, C. \\ Lake Sturgeon.}

A fair-sized sturgeon is occasionally taken from the nets far off shore in Lake Winnipeg, but since the advent of the steamboats in 1872 , they are never found about the post. Previous to that time they' were abundant at all seasons except during the month of March (according to McLean). Richardson ${ }^{2}$ states that, "The great rapid which forms the discharge of the Saskatchewan into Lake Winnipeg, appears quite alive with these fish in the month of June, and some families of the natives resort thither at that time to spear them with a harpoon, or grapple them with a strong hook tied to a pole." "The Saskatchewan sturgeon weighs from ten to twenty pounds, and rarely attains the weight of sixty." It is common in Cedar and Moose Lakes and along the Saskatchewan.

Sturgeon were caught at the narrows, the outlet of Cedar Lake, throughout the winter of 1892 . The isinglass, air blad-

1 Vide Schoolcraft, Part II, p. 5 I.

${ }^{2}$ Fauna, p. 280. 
der (nemaskwa), is purchased at the Company's posts for 67 cents a pound; ten fish furnish one pound.

Esox lucius Linn.

Ink-tă, D. R. Un-tă, S. Ŭl-tĭn, L.

JACKFISH.

The pike, or, as it is generally known in the North, the jackfish, is found throughout the region visited, but it is far less abundant than the whitefish and less esteemed for food.

I first saw them in Lake Winnipeg south of Grand Rapids where they were abundant in the reeds along the shore of shallow bays. I found them quite common on the north coast of the Great Slave Lake and in the Yellow Knife River. The Slavey Indians near the outlet of the lake were subsisting upon them when I passed that point in May, I894. The jackfish is said to be fat and well-flavored at that season but it was certainly inferor to the whitefish. My dogs were starving at that time yet they ate sparingly of them, and when well fed on whitefish, refused to eat jackfish.

Nets intended for their capture are made of "jackfish twine," somewhat heavier than that in other nets, but they are rarely used. Holes torn in the nets at Rae were generally attributed to the jackfish. 


\section{IN SECTS}

\section{Class HEXAPODA.}

THE insects ${ }^{1}$ collected on this expedition are comparatively 1 few in number, in consequence of the time being fully taken up with more conspicuous forms of life. Aside from a locust (Melanoplus bivittatus Say), an humble-bee, a Phryganeid and a small fly (Dilophus), all from Grand Rapids, they belong to the orders Lepidoptera and Coleoptera, and in general represent species which are characteristic of or common in the pine-covered regions of Canada and the country of the Great Lakes; some of them indeed extending even far to the southward of the Canadian boundary.

\section{Order LEPIDOPTERA.}

\section{Vanessa antiopa Linn.}

NYMPHALIDE.

Several specimens of this species, which is common to both of the northern continents, were obtained at Fort Rae in August.

Vanessa milberti Gdt.

Milbert's BUtterfly.

Fort Rae, August I2th.

Attacus cecropia Linn.

SATURNIDA.

One specimen, Fort Rae, August I2th.

Order COLEOPTERA.

CARABIDAE.

Trachypachys inermis Mots.

Slave Lake, one specimen. This species is widely distributed in North America, through the northern and mountain regions.

1 Report furnished by H. F. Wickham. 
It occurs in Alaska, Vancouver Island, Washington, Oregon, Idaho, and in the mountains of New Mexico and Colorado.

Bembidium variegatum Say.

Grand Rapids, L. Winnipeg. One specimen. Common in Canada and the United States.

Pterostichus orinomum Leach.

Grand Rapids. A common insect from Alaska to Labrador and occurring also in Oregon, Idaho, and the mountains of Colorado and Montana.

\section{Amara erratica Sturm.}

Grand Rapids. Northern America, Asia, Europe; in this country extending from Alaska to the Atlantic, south to Lake Superior and Vermont.

Platynus sinuatus $D e j$.

Slave Lake. Common in the northern regions from New England to British Columbia.

Platynus obsoletus Say.

Fort Rae. This has lately been placed in synonymy with $P$. bogemanni Gyll., of northern Europe. Alaska, Oregon, British Columbia, Canada, North Eastern and Middle States, west to Colorado. Siberia.

Platynus picipennis Kirby.

Slave Lake. Occurs in Canada and the Lake Superior region.

Harpalus basilaris Kirby.

Fort Rae, one specimen. Extends southward to Colorado and Wyoming (Greeley and Cheyenne).

DYTISCIDE.

Iybius pleuriticus Lec.

Slave Lake, on the ice. Also found in Pennsylvania, Iowa, and at Lake Superior. 
Gyrinus maculiventris Lec.

GYRINIDÆ.

Grand Rapids, one specimen.

Hydrobius fuscipes Linn.

HYDROPHILIDE.

Slave Lake. Common in Europe; in this country it extends across the northern half of the continent, from the Atlantic to Oregon and thence along the Pacific coast down to Southern California.

SILPHIDE.

Necrophorus pustulatus Hersch., var. melsheimeri Kirby.

Grand Rapids. A widely distributed northern form.

Silpha lapponica Herbst.

Grand Rapids and Fort Smith. Common in the northern and western portions of this continent and in the north of Europe.

STAPHYLINIDE.

Arpedium cribratum Fauv.

Slave Lake.

COCCINELLIDE.

Coccinella transversoguttata Fald.

Slave Lake and Fort Rae. Abundant in parts of Canada and the Rocky Mountain region of the United States; occurs also at Lake Superior, in Greenland, California and Mexico.

Coccinella monticola Muls.

Slave Lake. Also occurs at Lake Superior, in Oregon, Vancouver Island, and the Rocky Mountains of Colorado.

Corymbites morulus Lec.

ELATERIDÆ.

Fort Rae. Known also from Colorado.

Dicerca tenebrosa Kirby.

BUPRESTID王.

Fort Smith, Found not uncommonly in Canada and the states adjoining the Great Lakes. 
Melanophila longipes Say.

Fort Smith. Has a wide northern and montane distribution in the United States and Canada.

Ellychnia corrusca Linn.

LAMPYRIDE.

Grand Rapids. Common in Canada and most of the United States east of the Rocky Mountains.

Merium proteum Kirby.

CERAMBYCIDAE.

Fort Smith. Also occurs in Alaska, British Columbia, Canada, and our northern states.

Xylotrechus undulatus Say.

Grand Rapids. More or less abundant in British Columbia, Canada, and our northern states generally.

Leptura sexmaculata Linn.

Fort Smith. Reported also from Europe and Siberia, Canada, the Rocky Mountains, and several of our northern states.

Monohammus scutellatus Say.

Fort Smith.

\section{Monohammus confusor Kirby.}

Grand Rapids. Both of these are characteristic of the great belt of coniferous forests and its southern extension.

\section{CHRYSOMELIDE.}

Chrysomela multipunctata Say.

Fort Smith.

Galerucella nymphaeae Linn.

Slave Lake.

Haltica ignita $I l l$.

Fort Rae, All of these Chrysomelidæ are of wide distribution and common far to the southward of the localities in which they were taken. 
TENEBRIONIDE.

Upis ceramboides Linn.

Fort Smith. Europe and Asia; extends across the northern portion of North America, particularly in the coniferous belt from Maine to Montana.

CURCULIONIDE.

Lepyrus colon Linn.

Fort Smith. Found in Europe and Siberia; Mt. Washington, New Hampshire, Hudson's Bay region.

Pissodes affinis Rand.

Fort Smith.

SCOLYTIDÆ.

Xyloterus bivittatus Mann.

Slave Lake. Reported from Alaska, British Columbia, Canada, and our northern states in general, extending southward to California and New Mexico. 


\title{
LIST OF THE FOSSILS.
}

\author{
DEVONIAN.
}

MIDDLE DEVONIAN.

Cyathophyllum cæspitosum (Goldfuss) Meek.

Cyathophyllum arcticum Meek.

Cyathophyllum (sp?)

Cystiphyllum americanum var. arcticum Meek var.

Spirifer sublineatus Meek.

Cyrtina hamiltonensis Hall.

Atrypa reticularis Linnaæus.

Atrypa aspera Schlotheim.

Pentamerus comis Owen.

Newberria lævis Meek.

\section{UPPER CRETACEOUS.}

Unio (sp?)

LARAMIE.

Viviparus prudentius White.

Physa copei var. canadensis Whiteaves.*

*This last species is scarcely distinguishable from Bulimus disjunctus White. 



\section{INIEEX}

Acanthis linaria, . . . . 266

Accipiter atricapillus, . . . 261 velox, . . . . . . . 261

Acipenser rubicundus, . . . 274

Actitis macularia, . . . . 259

Aegialitis semipalmata, . . 260

Albino Caribou, Skin of, . 91, 226

Alces machlis, . . . . . . 229

method of capturing, . . 229

range of, . . . . . . 230

value of, . . . . . . 230

Aleutian Islands, . . . 155, 157

Allen, J. A., . . . . . . . 248

Amara erratica, . . . . . 277

Ammodramus sandwichensis alaudinus, . . . . . 267

Ampelis cedrorum, . . . . 268

Amulets, . . . . . . 183, 184

Anas americana, . . . . . 257

boschas, . . . . . . , 256

carolinensis, . . . . . 257

penelope, . . . . . . 257

Anthus pensilvanicus, . . . 269

Archibuteo lagopus sancti-jo-

hannis, . . . . . 262

Arctic Circle, across the, . . 134

Arctic Ocean, . . . . . . 140

Arpedium cribratum, . . . 278

Arrows, . . . . . . . . 192

Asio wilsonianus, . . . . , 262

Athabasca Lake, . . 49, 55, 59

landing, . . . . 49,51

river, . . 34, 40, 49, 55, 59

Grand Rapids of the, . 51, 55
PAGE.

Athabascans, . . . . . . 158

calendar, . . . . . . 165

education, . . . . . . 159

habits, . . . . . . 159

language, . . . . . 165

leaders, . . . . . . 164

lodges, . . . . . 160,161

migration, . . . . 161,162

provision, . . . . 163, 164

religion,. . . . . 162, 163

superstitions, . . . . . 163

Atkinson, "Old" Joe, . . . 2, 27

Attacus cecropia, . . . . . 276

Aurora, . . . . . . . 12

Ayee ecwoh, m' nitla! . . 90

Aythya affinis, . . . . . . 257

collaris, . . . . . . 257

Babiche, . . . . . . . 179

Back, Captain George, . 8, 66, 106

Bailey Island, . . . . . . 151

"Balæna," on board, . 147,148

Barren Ground, . . . 70, 71, 76

first sight of, . . . . . 111

journey through, . 112, 113

start for, . . . . . . 72

superstitions about. . . 71

Bear, grizzly, . . . . 138, 139 polar,. . . . . . 151,155

Begg, Alexander, . . . . . 28

Behring Sea, crossing, . . 155

Bembidium variegatum, . . 277

Big Island, . . . . . . . 131

fishing at, . . . . . 85

journey to, . . . . . 127 
Bird Darts, . . . . . . $\begin{array}{r}\text { PAGE } \\ 193\end{array}$

Birds, collecting in Delta, . . 60 at Grand Rapids, . 2, 10,33 at Herschel's Island, . . 149 on Mackenzie River, . 138 at Rae, . . , . . . . 86

Bison americanus, . . . 231 range of, . . . . 232

Bison antiquts, . . . 232

Boiler Rapids, running, . $\quad 55$

Bompas, Bishop, . . . . 29

Bonasa umbellus togata, . 260 numbellus umbelloides, . 260

Books printed in Cree syllabics,

Bow Drill, 184

Bows

Branta canadensis, . . 258 canadensishutchinsii, . 258

Breach of promise case at Grand Rapids,

Bryce, Dr.,

Bubo virginianus, . . . 262

Buffalo Hunt, . . . . . . 100

Buffalo River, night at,

Bull, Head, . . . . .

Burial Places of Crees, . .

Buteo borealis, .

Buttons,

"Cakes," .

Calcarius lapponicus, . . . 267

Calico Island, . . . . 33

Calidris arenaria, . . . . 259

Carnse11, J. S., . . . 45, 68, 160

Canis lagopus, . . . . 243 Inpus, . . . 241 vulpes, . . . . 242

Canoe model, . . . . . 184

Canoes, . . . 176, 177

Canoe trip across Great Slave Lake, . . . . . 79

Cape Bathurst, . . . . . 148

Cape Snythe, whaling stations at, . . . . . 152

Cape Tchaplin, . . . 155, 188

Cariacus macrotus, . . . . 22 t
Caribou hunt, first, . . . 88 preparations for hunt, . 74 superstitions about, . . 71

Carpodacus purpureus, . . . 266

Carrying Straps, . . . . 174

Cascade Rapids, . . . . 54

Castor canadensis, . . 251

Cedar Lake, . . . . . . 33

boat trip to . . . 10

Ceophloeus pileatus, . . 263

Ceryle alcyon, . . . . . 263

Charadrius dominicus . . 259

squatarola, . . . . 259

Chartier, Antoine, . . 29, 36

Chemawawin, Indian Reserve of, . . . . 10

arrival at, . . . 12

Chest Portage, . . . . . 61

Chillouis,. . . . . 104

Chippewyan, . . 45, 49, 56, 57

Chi-sai-witc-in,. . . . . . 135

Chordeiles virginianus, . 264

Christmas day, . . . . . 100

Chrysomela multipunctata, 279

Circus hudsonius, . . . 261

Clangula hyemalis, . . . . 139

Clay, edible, . . . . 133

Clearwater River, . . . . 55

Coccinella transversoguttata, 278 monticola, . . . . . 278

Cohoyla, Johnnie, 108, 109, 111, 112 $113,116,117,118,121,164$

Colaptes auratus, . . . 264 cafer, . . . . . . 264

"Colville," . . . . . 1

Colymbus holbollii, . . . 254 nigricollis californicus, . 254 pacificus, . . . . 139

Coppermine River, . 45, 71 in camp on, . . . . 112

Coregonus clupeiformis, . . 271 manner of cooking, . . 271 method of capture, . 273

Corvus americanus, . . 265 corax principalis, . 265

Corymbites morulus, . . . 278 


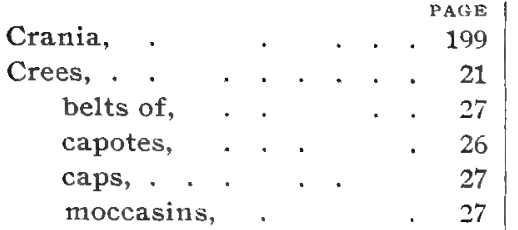

Cross Lake, . . . . . . . 11

Crow Nest Pass, . . . . 48

Cups, . . . . . . . . 184

Cyanocitta cristata, . . . . 264

Dafila acuta, . . . . . 257

Dawson, Capt. H. P., . 69, 87, 242

Deer, Dressing skin of, . 185, 186 snare, . . . . . 179

Demi-charge Rapids, . 11, 33, 35

Dendragapus canadensis, . . 260

Dendroica astiva, . . . 269 coronata, . . . . . 269

maculosa, . . . . 269

striata, . . . . . . 269

tigrina, . . . . . . . 269

Dicerca tenebrosa, . . . . 278

Dilophus, . . . 276

Dogs, cruel treatment of, . 15.16

disappearance of, . . . 111

driving, . . 14

feeding, . . . 95, 104

training, . . . . . . 15

shoes. . . . . 42,174

whips, . . . . . 179

Dog Head, journey to, . . . 4.3

Dog Ribs, . . 70, 71, 80, 109, 112 $114,115,116,119,123,162,163$ capotes of, . . . . . . 170 caps of, . . . 170,171 caribou skin, lodge of, . 168 clothing of, . . . 169 hunting frock, . . . . 169 leather gown of, . . . 170 leggins, . . . . . 171 moccasins, . . 172

Drake, Sir Francis, . . . 26

Drum, . . . . . . 176

drawings on, . . . . . 37

drumstick, . . . . . . 37

Dryobates pubescens, . . 263 villosus,

PACE

Duck-hunting, . . . . . 12,85

Duffels, . . . . . . 173

East Cape, settlement at, . 154

Easter among Dog Ribs, . . 110

Ecagoo, . . . . . . . 181

Eddy Brothers, hospitality of, 48

Edmonton, . . . 35, 49, 126

Embarras River, . . . . . 56

Emile, . . . . . . 79, 81

superstitions of, . . . 82

Empidonax minimus, . . 264

wrightii, . . . 264

Ereunetes pusilltus, . . . 259

Erismatura rubida, . . 258

Escape Reef, . . . . . 143

Eskino graves, . . . 145

Eskimos, Boots of, . . 189

buttons, . . . . . 190

camp, . . . . . . . 141

dress, . . 141,146, 187

frock of, . . . . 187, 188

hospitality of, $\quad 142$

mittens of, . $\quad . \quad$. 189

moccasins of, . . . . 172

rain frock, . . . . . . 188

trousers, 188

Esox lucius, . . . 275

Expedition, objects of, 45, 46, 223 plans of, . . . . 45, 124

Falco columbarius, . . . . 262

peregrinus anatum, . . 262

sparverius, . . 262

Faraud, Henri, . . 12,112, 159

Far North, . . . 34, 40, 106

Faville, Captain "Joe," . 50,51

Felis canadensis; . . . . . 240

Fiber zibethicus, . . 250

Fielden, Major, . . . 234, 248

Fire Bags, . . . . . . . 197

steel,. . . . . . . 175

Fisher Bay, . . . . . . . 43

Fishhooks, . . . 195

Fishing Lake, . . . . 75

"Flying Post," . . . . 33 


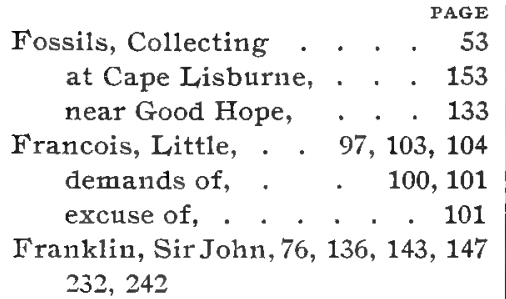

Frobisher, Benjamin, . . . 34

Fulmar glacialis rodgersii, . 256

Gale, loss from a terrific, . 10

Galerucella nymphææ, . . . 279

Gane Bags, . . . . . 178, 179

Gaudette, C. P., . . . . . 133

Grood Hope, . . . . 133

arrival at, . . . 133

start from, . . 134

"Grahame,". . 50, 51, 55, 57, 61

Grand Rapids, . . . . 41, 44

arrival at, . . . I

Grand Traverse, across, . . 105

Grand View, . . . 134

Grave of Indian Chief, . . . 3

Gravel Point, . . . . . 65

Great Bear Lake, . 45, 108, 162

Great Slave Lake, . . 40, 68, 131

sledge trip around,. . . 91

Gros Cape, . . . . . 82, 84

Gulo luscus, . . . . . . 240

Gun cases, . . . . . . 178

Gyrinus maculiventris, . . 278

Haliaëtus leucocephalıs, . 262

Haltica ignita, . . . . . 279

Hammer, . . . . . 195

Haploceros montanus, . . . 237

Hares, snaring, . . . . . 14

on Little Buffalo River, 102

Harness, . . . . . . 16

Harness swivels, . . . . 196

Harpalus basilaris, . . . 277

Harpoons, . . . . . . 193

Hay River, . . . . . . 96

natives of, . . . . . . 96

Hearne, Samuel, 132, 158, 164, 227, $228,229,233,247$.

Helminthophila peregrina, . 268
Herald Island, . . . . . 153

Herschel Island, 125, 134, 137, 138, $141,145,146$.

arrival at, . . . . . . 147

Hind, H. Y., . . 12, 33, 136, 181

Hislop, James, . . . . . . 251

Histrionicus histrionicus, . . 257

Hodgson, Jos., 78, 85, 105, 106, 124, $125,126,164,246$.

Houses of Crees, . . . . . 25

Hutdson's Bay Company, 2, 32, 33, $40,57,58$.

steamers of, . . . . 35

Humbug Bay, . . . . . . 43

Hydrobius fuscipes, . . . 278

Ice "Bucking," . . . . 148

Ice harvest, . . . . . 21

Idol, . . . . , . . , 180

Ilybius pleuriticus, . . . . 277

Jack Fiddler, . . . . . 19, 273

Jackfish Point, arrival at, . . 130

"Jeanette," . 152, 154

Junco hyemalis, . . . . . 267

Kay Point, . . . . 145, 150

Kelly, J. W., . . . . . . 144

King, Richard . . . . 65,230

Klotz, Otis J., . . . . . . 3

Knife, . . . . . . 184, 194

Labrets, . . . . . . 190

Ladles, . . . . . 177, 197

Laferté, Alexis, . . . . 79

Vita11, . . . . . 79,81

La France, Joseph, . . . . 34

Lagopıs lagopus, . . . . 260

rupestris, . . . . . . 261

La Grosse Ile, . . . . . 68

La Grosse Roche, . . . . . 69

Lahonton, Baron de . . . . 243

Lake Agassiz, . . . . . . 46

Lake Winnipegoosis, . . . 36

Lamps, . . . . . 195

Lanius borealis, . . . . . 268

Larus argentatus smithson-

ianus, . . . . . 255

delawarensis, . . . . 255

glaucus, . . . . . 255 


\begin{tabular}{|c|c|c|c|c|}
\hline \multirow{2}{*}{\multicolumn{3}{|c|}{ "Lee Tea," . . . . . . . $89,94,121$}} & \multicolumn{2}{|r|}{ PAGE } \\
\hline & & & Medicine Hat, & 46 \\
\hline Detour, . & & . . & Melanophila longipes, & . . 279 \\
\hline Eanus, & - & . 248 & bivittatus, & . . 276 \\
\hline & 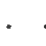 & 247 & Melospiza georgiana, & . 268 \\
\hline acula & & 279 & lincolni,. . . . & . . 268 \\
\hline , . . & - & . 280 & mephitica, . & . $\quad 238$ \\
\hline it & - & 2 & nericanus, & . 256 \\
\hline hroco & & . 266 & teum, . & . 279 \\
\hline . . . & . & . 132 & Merula migratoria, & . 270 \\
\hline re, . . & & 83,84 & .. & .. \\
\hline & & . 104 & "orchestra," . & . . \\
\hline iver, & & 101,102 & ig, . . . & 22 \\
\hline & & . 102 & himantop & 258 \\
\hline & & . 103 & W., & . $50,61,65$ \\
\hline & & 5 & & . . 127 \\
\hline & & & & ids, \\
\hline & & . 105 & & th- \\
\hline & & 135 & . $\cdot$ & 99 \\
\hline & & . 138 & $\cdot \cdots \cdot$ & . 173 \\
\hline $\mathrm{ra}$, . & & - 266 & varia, . & . . 268 \\
\hline & & 239 & of Eskit & 199 \\
\hline - & & 238 & & 265 \\
\hline & & 244 & nfusc & 279 \\
\hline & & $41,140,142$ & & 279 \\
\hline & & & g skin of & of, . 184,185 \\
\hline & & . . 230 & & . . \\
\hline Ir., . & & . $97,98,99$ & t, first, . . & . . . \\
\hline & & $.45,47,253$ & econd, . & $\therefore \quad \cdot$ \\
\hline & & & behavior & $f a$, . \\
\hline$\therefore$ & & 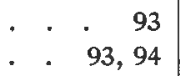 & $\begin{array}{llll}\text { g, } & \cdot & \cdot & . \\
. & . & . & .\end{array}$ & \\
\hline ette, . 1 & & & H., & . 251 \\
\hline & & 12 & , . . & . 190 \\
\hline & & 4 & F. C., & 148,23 \\
\hline & $\cdot$ & . . & Simpson, & . . . 13? \\
\hline & & . . & & . . 4,5 \\
\hline & & 69,132 & t sight of & . . . 11 \\
\hline & & 30 & s-ox h & . . 10 \\
\hline & & - 35,41 & outfit for, & . $\quad 10$ \\
\hline & & . . 55 & & 138,139 \\
\hline & & 134 & ricana, & \\
\hline & & & & $\cdot \cdot \cdot$ \\
\hline & & & Wood & \\
\hline
\end{tabular}




\begin{tabular}{|c|c|}
\hline & \\
\hline creation myth, & 205 \\
\hline how sea water became & le unfit to \\
\hline drink, . . . . & . . 217 \\
\hline how written, . & . . 201 \\
\hline length of, & . . 201 \\
\hline moose and hare, . & . . 216 \\
\hline moose and jackfish, & . . 217 \\
\hline okaskewaysesuk, . & . $\quad 211$ \\
\hline origin of animal fat, & . . 209 \\
\hline of change in & ermine's \\
\hline fur, $\cdot$. . & . 211 \\
\hline of touchwood, & . 212 \\
\hline owl and cascade, . & . . 217 \\
\hline story of the deluge, & . . 206 \\
\hline Teena's story, & . . 220 \\
\hline thunderbolt, . & . . 210 \\
\hline $\begin{array}{l}\text { Waimesesoo, } \\
\text { tricks of, }\end{array}$ & $\begin{array}{r}203,204 \\
\cdot \quad 204\end{array}$ \\
\hline why trees are twisted, & . 208 \\
\hline Wisagatchak,. . . & 201,206 \\
\hline as a doctor, & . 207 \\
\hline bear and,. . & \\
\hline beaver and, & . . 213 \\
\hline becones blind, & 215 \\
\hline beginning of & wander- \\
\hline ings, . & . 202 \\
\hline end of, . & . . 216 \\
\hline his brother,. & 203,206 \\
\hline his wife, . . & . . 204 \\
\hline nighthawk and & . 210 \\
\hline Nahanni mountains, & . . 132 \\
\hline river, . & 132 \\
\hline Napasis, . . . . & . . 4,5 \\
\hline Narrows, . . . . . & 33,43 \\
\hline Necrophorus pustulatus, & . . 278 \\
\hline Needle cases, . . . & . . 197 \\
\hline "Nesoo mo-ni-as-uk,", & . . \\
\hline Net floats, . . & . 195 \\
\hline sinkers, & 195 \\
\hline Netting needles, , . & 195 \\
\hline New Year's day, . . . & . 23,100 \\
\hline Nine Lakes, . . . . . & . 75,77 \\
\hline Nomonyx dominicus, . & . $\quad 258$ \\
\hline Norman, . . . . . & . . 133 \\
\hline Nucifraga columbiana, . & . .265 \\
\hline $\begin{array}{c}\text { Nutting, Prof. C. C., 4, } \\
237,253\end{array}$ & , 46,124 \\
\hline
\end{tabular}

Odemia perspicillata, PAGE

Ogilvie, William, . . . . 231

"Old John," . . . . 93, 94, 97

O1d Peter, . . . . 47, 48

Omiaks, . . . . . . . . 197

Ooskanatchet, . . . 35, 36, 37, 38 medicine drun of, . . . 36 peace-pipe of, . . . . . 36

Otocoris alpestris leucolœma, 264

Outfit, supplies in, . . . . 49

Ovibos moschatus, . . . . 232 method of capture, . $\quad 235$ range of,. . . . . . 235

Ovis montana, . . . . 236 montana dalli, . . . 236

Pack saddle, . . . . . 182

Paddles, . . . . . . . . 184

Pandion haliæetus carolinensis, 262

Parry, Capt. W. E., . . 244, 248

Parus atricapillus, . . . 269

Parus atricapillus septentrionalis, 270

hudsonicus, . . . 270

Pauguk, . . . . . . 36

Pauline harbor, . . . 148, 151 settlements at, . . . . 149

Pediocæetes phasianellus, . . 261

Peel river, . . . . 136, 137, 138

Pelecanus erythrorhynchus, . 256

Perisoreus canadensis, . . 205, 264

Peromyscus leucopus articus-? 250

Petitot, Emile, 32, 144, 167, 201, 202

Phalaropus lobatus, . . . . 258

Phillips Bay, settlement on, . 145

Picoides americanus alascensis, 263 arcticus, . . . . . . 263

Pike, Warburton, . 26, 63, 124, 235

Pincher Creek, . . . . . . 47

Pinicola enucleator, . . . . 266

Pipes, . . . . . 180, 184, 190

Piranga 1udoviciana, . . . 268

Pissodes affinis, . . . . . 280

Plains, present condition of, 48,49

Platynus obsoletus, . . . . 277 picipennis, . . . . . . 277 


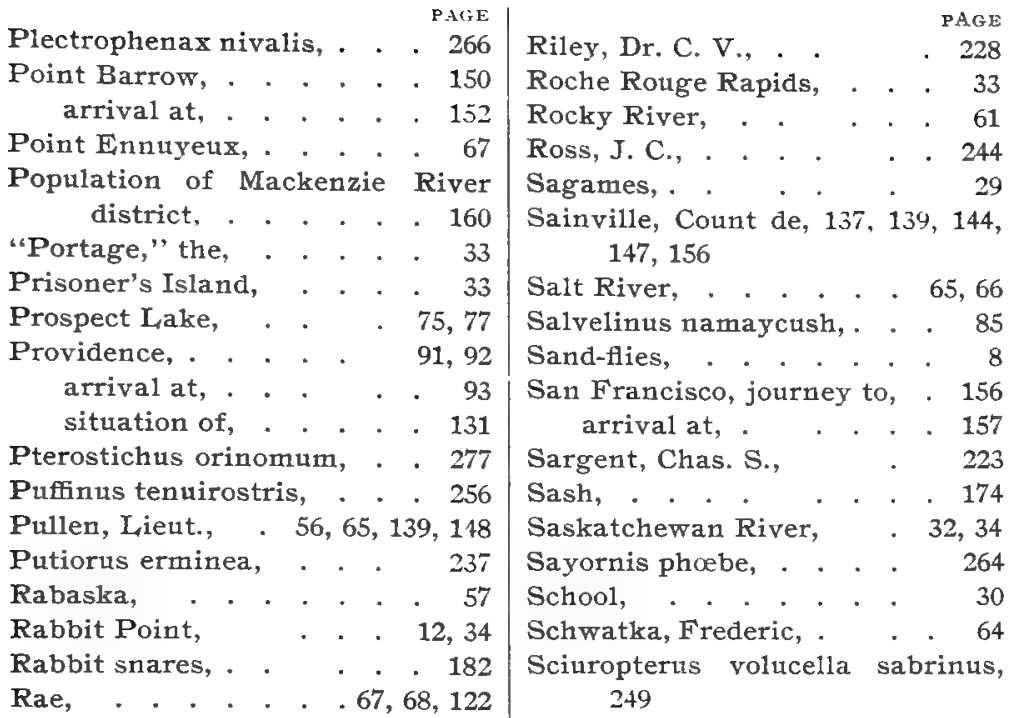

arrival at, . . . . 78

October at, . . . . . . 85

Periodical events recorded at, 86

situation of, . . . . . 69

Ramparts, . . . . . 133

Rangifer tarandus, . . . 225

method of capture, . . 227

range of, . . . . . . 226

value of, . . . . . . 228

Rangifer tarandus caribou, . 224 range of, . . . . . . 224

Rattle, . . . . . . . 180

Ravens, . . . . . 143, 150

Reade, . . . . . . . . 19

Red Deer River, . . . . . 36

Red River, . . . . . 1, 34, 35

Regulus calendula, . . . . 270

Reindeer Island, . . . . 42

Resolution, . . . 45, 67, 83, 85

arrival at, . . . . 97

fishing at, . . . . . . 85

scarcity of supplies at, . 97

Return Reef, . . . . . . 151

Richardson, Sir John, 63, 64, 136, $228,232,234,271,274$
Sciurus hudsonius, . . . . 249

Scolecophagus carolinus, . . 266 cyanocepha1us, . . . . 266

Scotiaptex cinereum, . . . 262

Scrapers for dressing skins, 177,198

Seebohm, Henry, . . . . . 223

Segur, Capt., . . . 51, 53, 55

Seiurus noveboracensis notabilis, 269

Selkirk, . . . . . . 1,44

Separation, Point, . . . . 136

Setophaga ruticilla, . . . . 269

Shoalwater Bay, . . . . 140

Shot pouches, . . . . . 175

Silpha lapponica, . . . . 278

Simpson, . . . . . +5

arrival at, . . . . . 132

Simpson's Group, . . . . 83

Simpson, Thomas, . . . 135

Sinew, . . . . . . . 176

Slave River, . . . . . 65, 66, 101

Slaveys, . . . . . 162

Sleds, . . . . . . . . 17

size of the load, . . . . 16

Sleeping-bag, . . . . . . 96

in a, . . . . . 96 


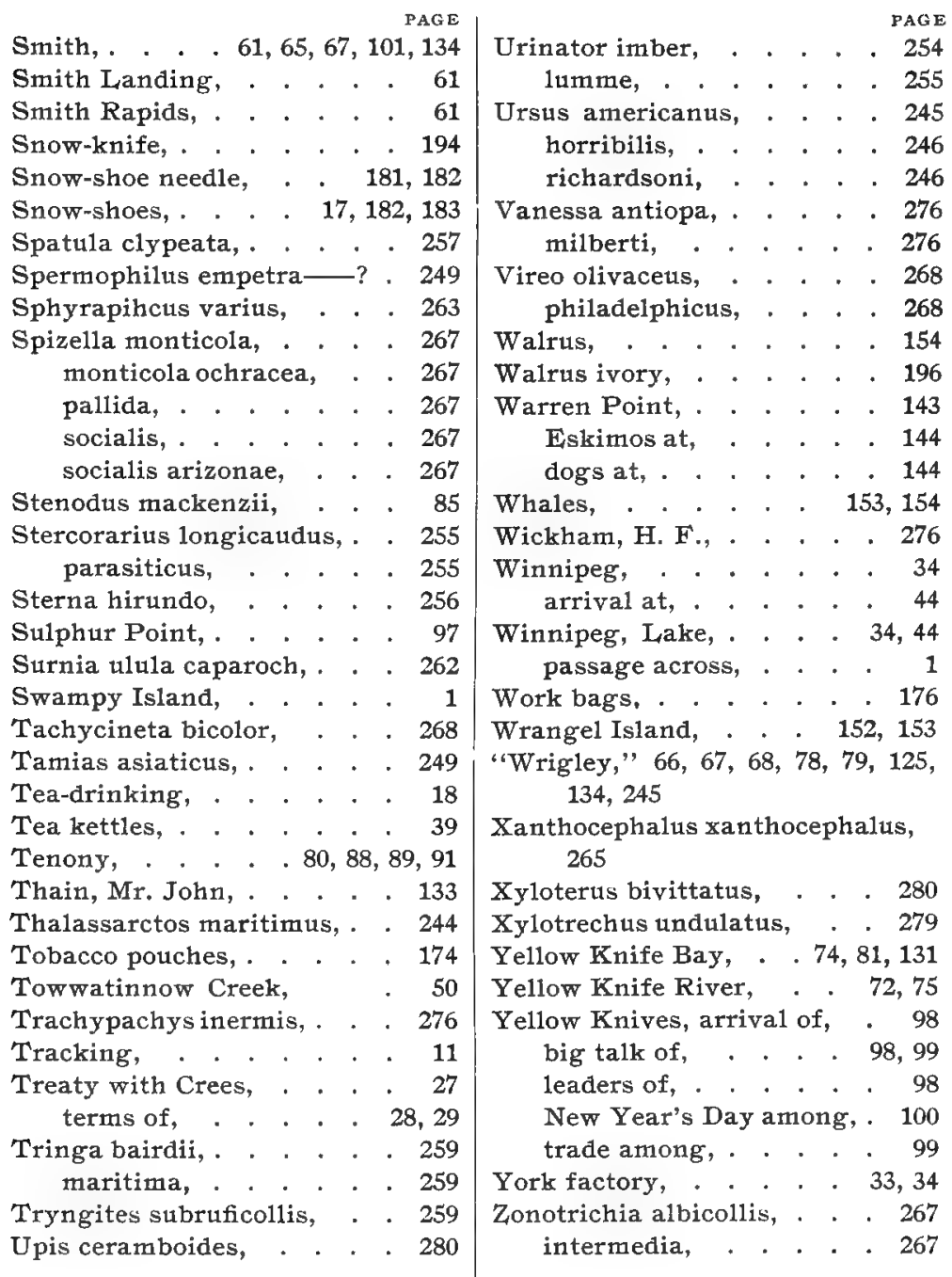








